
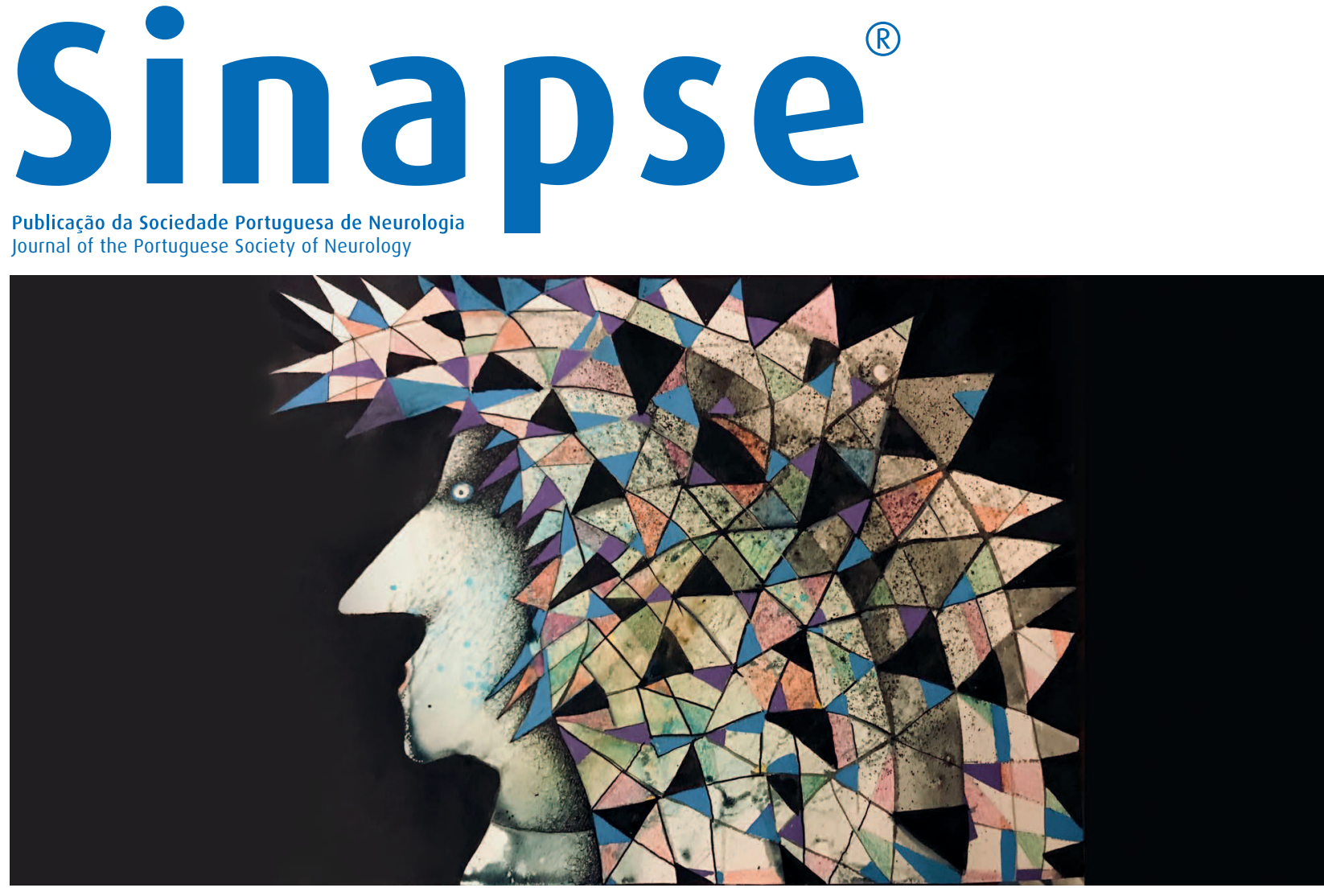

Recomendações Terapêuticas para Cefaleias da Sociedade Portuguesa de Cefaleias - 2021

Headache Treatment Guidelines of the Portuguese Headache Society - 2021
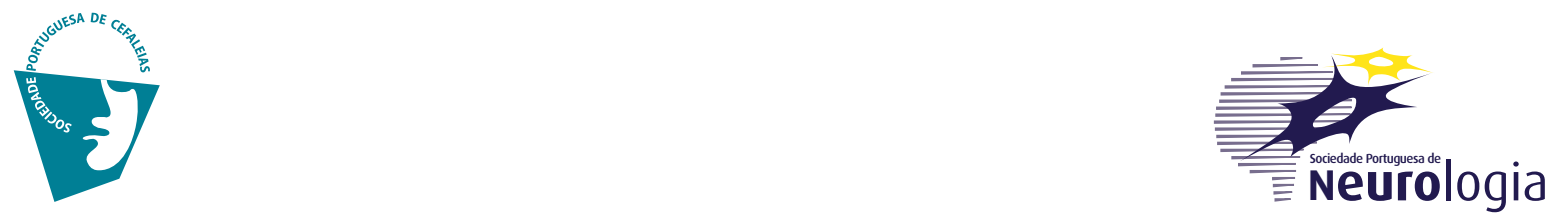



\section{Sumário/Table of Contents}

Recomendações Terapêuticas para Cefaleias da Sociedade Portuguesa de Cefaleias - 2021 /

Headache Treatment Guidelines of the Portuguese Headache Society - 2021

6

\section{Introdução}

\section{Princípios Gerais no Tratamento das Cefaleias}

\section{Enxaqueca}

3.1 Medidas Gerais

3.2 Tratamento Sintomático da Crise de Enxaqueca

3.3 Tratamento Preventivo da Enxaqueca Episódica

3.4 Tratamento da Enxaqueca Crónica

\section{Cefaleia Tipo Tensão}

\section{Cefaleias Trigémino-autonómicas}
5.1 Cefaleias em Salvas
5.2 Hemicrânia Paroxística e Hemicrânia Contínua
5.3 SUNCT (Short-lasting Unilateral Neuralgiform Headache Attacks with Conjunctival Injection and Tearing)
/ SUNA (Short-lasting Unilateral Neuralgiform Headache Attacks with Autonomic Symptoms)

\section{Outras Cefaleias Primárias}

\section{Nevralgia do Trigémeo}

\section{Cefaleia por Uso Excessivo de Medicamentos}

\section{Situações Particulares}

9.1 Recomendações Terapêuticas das Cefaleias Primárias na População Pediátrica

9.2 Recomendações Terapêuticas das Cefaleias Primárias nas Mulheres em Fase Fértil, Gravidez, Amamentação e Menopausa

9.3 Tratamento das Cefaleias em Pessoas Idosas e com Comorbilidades

\section{Interações Farmacológicas no Tratamento das Cefaleias}

\section{Siglas e Abreviaturas}

Instruções aos Autores e Políticas Editoriais / Instructions for Authors and Editorial Policies 


\section{Sinapse ${ }^{\circ}$}

Publicação da Sociedade Portuguesa de Neurologia

Órgão oficial / Affiliations:

Sociedade Portuguesa de Neurologia; Associação

Portuguesa de Electrofisiologia e Neurofisiologia Clínica;

Conselho Português para o Cérebro; Grupo de Estudos de

Envelhecimento Cerebral e Demências; Grupo de Estudos de Esclerose Múltipla; Liga Portuguesa Contra a Epilepsia; Sociedade Portuguesa do Acidente Vascular Cerebral; Sociedade Portuguesa de Cefaleias; Sociedade Portuguesa das Doencas do Movimento; Sociedade Portuguesa de Estudos de Doenças Neuromusculares; Sociedade Portuguesa de Neurocirurgia; Sociedade Portuguesa de Neuropediatria

\section{Director / Director:}

Isabel Luzeiro (Presidente da Sociedade Portuguesa de Neurologia), Centro Hospitalar Universitário de Coimbra Coimbra, Portugal

Editor-Chefe / Editor-in-Chief:

Catarina Resende Oliveira, Centro de Neurociências de Coimbra, Coimbra, Portugal

\section{Editores Associados / Associate Editors:}

Filipe Palavra, Centro Hospitalar e Universitário de Coimbra e Faculdade de Medicina da Universidade de Coimbra, Coimbra, Portugal

Miguel Rodrigues, Hospital Garcia de Orta, Almada, Portugal

José Vale, Hospital Beatriz Ângelo, Loures, Portugal Elsa Parreira, Hospital Prof. Doutor Fernando da Fonseca, Amadora, Portugal

Cristina Januário, Faculdade de Medicina da Universidade de Coimbra, Coimbra, Portugal

Maria José Sá, Centro Hospitalar e Universitário de S. João, Universidade Fernando Pessoa, Porto, Portugal

João Lemos, Centro Hospitalar e Universitário de Coimbra e Faculdade de Medicina da Universidade de Coimbra,

Coimbra, Portugal

Teresa Coelho, Centro Hospitalar Universitário do Porto e Instituto de Ciências Biomédicas de Abel Salazar, Porto, Portugal

Manuel Melo Pires, Centro Hospitalar Universitário do

Porto e Instituto de Ciências Biomédicas de Abel Salazar, Porto, Portugal

Patrícia Canhão, Centro Hospitalar Universitário de Lisboa Norte e Faculdade de Medicina da Universidade de Lisboa, Lisboa, Portugal

Pedro Alberto Silva, Centro Hospitalar e Universitário de $S$. João e Faculdade de Medicina da Universidade do Porto, Porto, Portugal

Sónia Batista, Centro Hospitalar e Universitário de

Coimbra, Coimbra, Portugal

Leonor Correia Guedes, Centro Hospitalar Universitário de Lisboa Norte, Lisboa, Portugal

Luís Maia, Centro Hospitalar Universitário do Porto, Porto, Portugal

Manuel Correia, Centro Hospitalar Universitário do Porto, Porto, Portugal

Ricardo Taipa, Centro Hospitalar Universitário do Porto, Porto, Portugal

Sofia Reimão, Centro Hospitalar Universitário de Lisboa Norte, Lisboa, Portuga
Conselho Editorial / Editorial Board

José Barros, Centro Hospitalar Universitário do Porto e Instituto de Ciências Biomédicas de Abel Salazar, Porto, Portugal

Isabel Pavão Martins, Centro Hospitalar Universitário de Lisboa Norte e Faculdade de Medicina da Universidade de Lisboa, Lisboa, Portugal

José Ferro, Centro Hospitalar Universitário de Lisboa Norte e Faculdade de Medicina de Lisboa, Lisboa, Portuga Miguel Viana Baptista, Centro Hospitalar de Lisboa Ocidental e Faculdade de Ciências Médicas, Universidade Nova de Lisboa, Lisboa, Portugal

Mamede de Carvalho, Centro Hospitalar Universitário de Lisboa Norte e Faculdade de Medicina da Universidade de Lisboa, Lisboa, Portugal

António Martins da Silva, Centro Hospitalar Universitário do Porto e Instituto de Ciências Biomédicas de Abel Salazar, Porto, Portugal

Raquel Gil-Gouveia, Hospital da Luz e Faculdade de Medicina da Universidade de Lisboa, Lisboa, Portugal Vítor Oliveira, Centro Hospitalar Universitário de Lisboa Norte e Faculdade de Medicina da Universidade de Lisboa, Lisboa, Portugal

José Pimentel, Centro Hospitalar Universitário de Lisboa Norte e Faculdade de Medicina da Universidade de Lisboa, Lisboa, Portugal

Consultora de Estatística / Statistical Consultant: Maria Carolina Silva, Instituto de Ciências Biomédicas Abel Salazar, Universidade do Porto, Porto, Portugal

Editor Técnico / Technical Editor:

Helena Donato, Centro Hospitalar e Universitário de Coimbra, Coimbra, Portugal

\section{Assistente Editorial / Editorial Assistant}

Ana Catarina Lopes

Propriedade, Edição e Administração /

Property, Editing and Management:

Sociedade Portuguesa de Neurologia

Open Access:

A revista SINAPSE ${ }^{\circledR}$ está licenciada com uma Licença Creative Commons - Atribuicão-Não Comercial-Sem Derivações 4.0 Internacional.

SINAPSE is licensed under a Creative Commons Attribution-Non Commercial-No Derivatives 4.0 International License.

CC BY-NC
Periodicidade / Periodicity:

Trimestral

Versão electrónica / Electronic version:

www.sinapse.pt

Indexação / Indexing-Abstracting:

EMBASE - Elsevier

SCOPUS - Elsevie

IndexRMP

Contactos / Editorial Contacts:

Sociedade Portuguesa de Neurologia

Trav. Álvaro Castelões, $n^{\circ}$ 79- $2^{\circ}$ andar-sala 9

4450-044 Matosinhos, Portugal

Im.: +351933205202

Correio electrónico / Email: sinapse.spn@gmail.com

Design / Publishing:

Next Color, Porto

Imagem de capa: aguarela da autoria de Manuela Crespo

Produção gráfica / Graphic production: Porto

Registo / Register: Isenta de registo por não estar à disposição do público em geral (Despacho da ERC em 05/12/2012)

Impressa em papel ecológico e livre de cloro, papel não ácido/Printed in acid-free paper

Registo de Marca / Trade Mark: 358268 (Instituto

Nacional de Propriedade Industrial)

ISSN: $1645-281 \mathrm{X}$

E-ISSN: $2184-4240$

Depósito Legal / Legal Deposit: 172 674/01

Tiragem / Edition: 2000 exemplares / 2000 units

Preço unitário / Price per number: $10 €$

Assinatura anual / Annual subscription: $15 €$

A SINAPSE ${ }^{\oplus}$ está conforme os princípios e procedimentos ditados pelo Committee on Publication Ethics (COPE) www.publicationethics.org

This journal subscribes to the principles and guidelines of the Committee on Publication Ethics (COPE) www. publicationethics.org

Revista Oficial da Sociedade Portuguesa de Neurologia (www.spneurologia.com)

Official Journal of the Portuguese Society of Neurology (www.spneurologia.com) 


\title{
GUIDELINES
}

\section{Recomendações Terapêuticas para Cefaleias da Sociedade Portuguesa de Cefaleias - 2021}

\author{
Headache Treatment Guidelines of the Portuguese Headache Society - 2021
}

\author{
Elsa P Parreira 1, (D) Carlos A Fontes Ribeiro 2, (D) Helena Gens 3, (D) Filipe Palavra 4, (D) Inês Brás Marques ${ }^{5}$, \\ (D) Inês Carrilho 6, (D) Isabel Luzeiro ${ }^{7}$, (D) Isabel Pavão Martins ${ }^{8}$, Jorge Machado ${ }^{9}$, (D) José Pereira Monteiro ${ }^{10}$, \\ Liliana Pereira 11, Miguel Rodrigues ${ }^{12}$, Paula Esperança ${ }^{13}$, (D) Raquel Gil-Gouveia ${ }^{14}$, Sara Machado ${ }^{15}$ \\ 1-Serviço Neurologia e Consulta de Cefaleias, Hospital Professor Doutor Fernando Fonseca, Amadora, Portugal \\ 2-Faculdade de Medicina, Universidade de Coimbra, Coimbra, Portugal \\ 3-Serviço de Neurologia, Centro Hospitalar Universitário de Coimbra, Coimbra, Portugal \\ 4-Centro de Desenvolvimento da Criança - Neuropediatria, Hospital Pediátrico, Centro Hospitalar e Universitário de Coimbra, Coimbra, \\ Portugal e Instituto de Investigação Clínica e Biomédica de Coimbra (iCBR), Faculdade de Medicina da Universidade de Coimbra, \\ Coimbra, Portugal \\ 5-Centro de Cefaleias e Serviço de Neurologia, Hospital da Luz, Lisboa, Portugal \\ 6-Serviço de Neuropediatria do Centro Materno Infantil do Norte, Centro Hospitalar Universitário do Porto, Porto, Portugal \\ 7-Consulta de Cefaleias e Serviço de Neurologia, Centro Hospitalar Universitário de Coimbra, Coimbra, Portugal \\ 8-Consulta Cefaleias, Hospital Santa Maria, Centro Hospitalar Universitário Lisboa Norte, Lisboa, Portugal e Faculdade de Medicina, \\ Universidade de Lisboa, Lisboa, Portugal \\ 9-Consultório Privado, Almada, Portugal \\ 10-Instituto de Biologia Molecular e Celular, Instituto de Investigação e Inovação em Saúde, Universidade do Porto, Porto, Portugal e \\ Unidade de Cefaleias, Centro de Neurociências, Hospital e Instituto CUF Porto, Porto, Portugal \\ 11-Consulta de Cefaleias e Serviço Neurologia / Hospital Garcia de Orta, Almada, Portugal \\ 12-Serviço Neurologia, Hospital Garcia de Orta, Almada, Portugal \\ 13-Serviço de Neurologia, Centro Hospitalar Universitário Lisboa Central - Hospital Santo António dos Capuchos, Lisboa, Portugal \\ 14-Centro de Cefaleias, Serviço de Neurologia, Hospital da Luz - Lisboa, Portugal e Consulta de Cefaleias, Serviço de Neurologia, Centro \\ Hospitalar Universitário Lisboa Norte, Lisboa, Portugal \\ 15-Consulta de Cefaleias e Serviço de Neurologia, Hospital Professor Doutor Fernando Fonseca, Amadora, Portugal
}

DOI: https://doi.org/10.46531/sinapse/GU/200048/2021

\section{Resumo}

Introdução: As normas de orientação terapêutica são documentos úteis de apoio à prática clínica. Procedemos à atualização das anteriores normas elaboradas pela Sociedade Portuguesa de Cefaleias.

Objetivo: Este documento destina-se a fornecer recomendações terapêuticas baseadas na evidência para os diferentes tipos de cefaleias primárias, nevralgia do trigémeo e para a cefaleia secundária a uso excessivo de medicação.

Métodos: Elaboração de recomendações terapêuticas por grupo de peritos da Sociedade Portuguesa de Cefaleias, segundo níveis de evidência e graus de recomendação, tendo por base a revisão de normas anteriores, o resultado de ensaios clínicos, a adaptação de normas de sociedades científicas internacionais e nas cefaleias raras, a opinião de peritos e relatos de séries.

Resultados: São abordadas intervenções não farmacológicas, como medidas gerais e terapêuticas alternativas: terapias cognitivo-comportamentais, técnicas de retrocontrole biológico e acupuntura. São fornecidas orientações sobre o tratamento agudo da enxaqueca não específico (analgésicos e anti-inflamatórios) ou específico (triptanos). No tratamento preventivo da enxaqueca episódica são enunciados os critérios para início de tratamento e as regras gerais para a utilização dos preventivos orais de primeira linha com evidência de eficácia: beta-bloqueantes, antiepiléticos, flunarizina e antidepressivos tricíclicos. São pela primeira vez introduzidos os fármacos preventivos de segunda linha: anticorpos monoclonais anti-CGRP (péptido
Informações/Informations:

Guidelines, publicado

em Sinapse, Volume 21,

Suplemento 1, abril 2021.

Versão eletrónica em www.

sinapse.pt

Guidelines, published

in Sinapse, Volume 21

Supplement 1, april 2021.

Electronic version in www.

sinapse.pt

(C) Autor (es) (ou seu (s)

empregador (es)) e Sinapse

2021. Reutilização permitida

de acordo com CC BY-

NC. Nenhuma reutilização

comercial.

(C) Author(s) (or their

employer(s)) and Sinapse 2021.

Re-use permitted under CC BY-

NC. No commercial re-use.

Palavras-chave:

Cefaleia/tratamento;

Gestão da Dor;

Guias de Prática Clínica;

Perturbações de Enxaqueca/ tratamento. 


\section{Keywords:}

Headache/therapy;

Migraine Disorders/therapy;

Pain Management;

Practice Guidelines as Topic.

*Autor Correspondente / Corresponding Author: Elsa Paixão Parreira

Rua Ladislau Patricio - $8-13^{\mathrm{a} C}$

1750-136 Lisboa, Portugal elsaparreira@hotmail.com

Recebido / Received: 2020-09-09 Aceite / Accepted: 2020-12-21 Publicado / Published: 2021-05-31 relacionado com o gene da calcitonina), fremanezumab, galcanezumab, eptinezumab, e anti-rCGRP, erenumab, suas indicações e regras de administração. A enxaqueca crónica, com tratamento preventivo indicado em todos os doentes, tem abordagem diferenciada com preventivos orais de primeira linha (topiramato), e as terapias anti-CGRP e a toxina onabotulínica A como preventivos de segunda linha. Para a cefaleia tipo tensão e as cefaleias trigémino-autonómicas, apresentam-se as guidelines para tratamento abortivo e preventivo. Na nevralgia do trigémeo são apresentados os fármacos com evidência de eficácia, mas também intervenções, nomeadamente cirúrgicas, a ponderar nos casos refratários. São também dadas orientações para o manejo da cefaleia por uso excessivo de medicação. Populações especiais como crianças, mulheres que pretendam engravidar, grávidas, mulheres que amamentam e idosos polimedicados têm orientações específicas para o tratamento das cefaleias. São analisadas ainda as interações farmacológicas mais relevantes dos fármacos agudos e preventivos, nomeadamente a nível farmacocinético.

Conclusão: Neste documento são atualizadas recomendações terapêuticas para as cefaleias.

\section{Abstract}

Background: Therapeutic guidelines are useful tools in clinical practice. We updated previous Portuguese Headache Society Therapy Guidelines.

Objectives: To provide healthcare professionals updated evidence-based guidance on treatments for the primary headaches, trigeminal neuralgia and medicationoveruse headache.

Methods: This statement authored by a group of experts from the Portuguese Headache Society, was based on a review of existing national headache guidelines, results of relevant clinical trials, review of international guidelines and in case of rare diseases expert opinion and results from small case series.

Results: Nonpharmacological interventions for headache management such as general measures, avoiding medication overuse and alternative therapies such as cognitive-behavioural techniques, biofeedback and acupuncture are addressed. Evidence based acute migraine drug treatment (nonspecific - simple analgesics and nonsteroidal anti-inflammatories or specific - triptans) guidance is provided. For episodic migraine, preventive therapy criteria are listed and general rules for using first line oral preventives with proven efficacy (beta-blockers, antiepileptic drugs, flunarizine and tricyclic antidepressants) are provided. Second line preventive drugs such as monoclonal antibodies anti-CGRP (calcitonin gene related peptide), fremanezumab, galcanezumab and eptinezumab, or anti CGRP receptor, erenumab, are also addressed. In chronic migraine, all patients should be on prophylactic treatment whether the first line oral drugs (topiramate) or in its failure with second line drugs: onabotulinumtoxinA or anti-CGRP therapies. Acute and preventive guidelines for tension type headache and trigeminal-autonomic cephalalgias are provided. In what concerns trigeminal neuralgia evidence based pharmacologic guidance is discussed but other interventions such as surgery should be considered in refractory patients. Evidence based management of medication overuse headache is addressed. Special populations such as children, pregnant or lactating women and elderly patients with multiple comorbidities and polypharmacy deserve specific guidelines. Relevant drug interactions, especially pharmacokinetic interactions with headache preventive and abortive drugs are explored.

Conclusion: This statement provides evidence based updated headache treatment guidelines. 


\section{INTRODUÇÃO}

As cefaleias em geral e a enxaqueca e cefaleia tipo tensão em particular, pela sua elevada prevalência e repercussão sobre a qualidade de vida do individuo, constituem um importante problema de saúde pública. Segundo dados publicados pela Organização Mundial de Saúde (OMS) a cefaleia tipo tensão e a enxaqueca são respetivamente a terceira e a sexta, doenças mais prevalentes a nível mundial e a enxaqueca a segunda doença que mais anos vividos com incapacidade provoca.' Elas são motivo frequente de consulta quer na Medicina Geral e Familiar quer nas especialidades e acarretam significativos custos diretos (pelo recurso a cuidados de saúde) e indiretos (pelo absentismo e presencismo) para os orçamentos de cada país.

Constata-se que, infelizmente, mesmo em países com cuidados de saúde de excelência como são os países da União Europeia, e considerando unicamente a enxaqueca, apenas $15 \%$ a $20 \%$ dos doentes recorreu a um profissional de saúde por causa das suas cefaleias, só 3,5\% a 10\% tem acesso a terapêuticas agudas específicas e eficazes e uma percentagem significativamente inferior (entre I,5\% e 6,4\%) está corretamente medicada com preventivos. ${ }^{2}$

Esta realidade, afortunadamente, tem vindo lentamente a modificar-se graças em grande parte aos esforços desenvolvidos na campanha 'Lifting the Burden: the global campaign against Headache' em que participa a OMS em parceria com outras organizações de saúde internacionais.

A Sociedade Portuguesa de Cefaleias (SPC) tem publicado regularmente recomendações terapêuticas para as cefaleias mais comuns, adaptadas à realidade nacional de modo a apoiar a prescrição médica. A última dessas publicações data já de $2009^{3}$ pelo que se impunha a sua atualização.

As recomendações terapêuticas são um instrumento que facilita a tomada de decisões na abordagem dos doentes permitindo a melhor prática clínica baseada na evidência científica. Não pretendem de modo nenhum substituírem-se ao clínico na sua decisão, mas permitem uma escolha terapêutica mais eficiente, mais segura e mais custo-efetiva. Esta ferramenta de apoio ao clínico é tão útil ao médico generalista (obviamente menos familiarizado com as práticas clínicas correntes nesta área especializada da Medicina) como ao neurologista especializado em cefaleias. Incorporámos neste manual o resultado da revisão da evidência científica publicada na literatura bem como as recomendações de organizações científicas internacionais como a European Headache Federation
(EHF) e a International Headache Society (IHS). Infelizmente nem sempre existe suficiente evidência científica para suporte das orientações terapêuticas; é o caso das cefaleias mais raras em que não existem ensaios clínicos. Nestes casos apresentamos a opinião de peritos baseados nos relatos existentes na literatura.

Este manual não pretende ajudar ao diagnóstico das várias entidades. Para isso remetemos o leitor para a Classificação Internacional de Cefaleias, $3^{\mathrm{a}}$ edição (ICHD3) da IHS, onde encontrará os critérios de diagnóstico atualizados para todos os tipos de cefaleias primárias e secundárias e ainda para as nevralgias e dores faciais. A tradução portuguesa ${ }^{4}$ desta última versão da classificação, realizada por membros da SPC, encontra-se disponível e de acesso livre na página web da nossa sociedade.

Contemplamos no início deste documento os princípios gerais de tratamento comuns à maioria das cefaleias crónicas com especial enfoque nas terapias não farmacológicas e na mudança dos estilos de vida.

Abordaremos o tratamento farmacológico das várias entidades considerando os níveis de evidência e os graus de recomendação adotados pela Direção Geral de Saúde (Tabelas 1.1 e 1.2). ${ }^{5}$

Tabela 1.1. Graus de recomendação ${ }^{5}$

\begin{tabular}{|l|l|}
\hline $\begin{array}{l}\text { Grau de } \\
\text { recomendação }\end{array}$ & Descritivo \\
\hline Grau I & $\begin{array}{l}\text { Existem evidências e/ou consenso geral } \\
\text { de que determinado procedimento/ } \\
\text { tratamento é benéfico, útil e eficaz. }\end{array}$ \\
\hline Grau II & $\begin{array}{l}\text { Existem evidências contraditórias e/ } \\
\text { ou divergência de opiniões sobre a } \\
\text { utilidade/eficácia de determinado } \\
\text { tratamento ou procedimento. }\end{array}$ \\
\hline Grau Ila & $\begin{array}{l}\text { Evidências/opinião maioritariamente a } \\
\text { favor da utilidade/eficácia }\end{array}$ \\
\hline Grau IIb & $\begin{array}{l}\text { Utilidade/eficácia pouco comprovada } \\
\text { pelas evidências/opinião. }\end{array}$ \\
\hline Grau III & $\begin{array}{l}\text { Existem evidências e/ou consenso } \\
\text { geral de que determinado } \\
\text { procedimento/tratamento não é } \\
\text { benéfico/eficaz e poderá ser em certas } \\
\text { situações prejudicial. }\end{array}$ \\
\hline
\end{tabular}

Tabela 1.2. Níveis de evidência ${ }^{5}$

\begin{tabular}{|l|l|}
\hline $\begin{array}{l}\text { Nível de } \\
\text { evidência }\end{array}$ & Descritivo \\
\hline Nível A & $\begin{array}{l}\text { Informação recolhida a partir de vários ensaios } \\
\text { clínicos aleatorizados ou meta-análises. }\end{array}$ \\
\hline Nível B & $\begin{array}{l}\text { Informação recolhida a partir de um único } \\
\text { ensaio clínico aleatorizado ou estudos } \\
\text { alargados não aleatorizados. }\end{array}$ \\
\hline Nível C & $\begin{array}{l}\text { Opinião consensual dos especialistas e/ou } \\
\text { pequenos estudos, estudos retrospetivos e } \\
\text { registos. }\end{array}$ \\
\hline
\end{tabular}


Especial relevo mereceu a enxaqueca (episódica e crónica), pela sua elevada prevalência e impacto na qualidade de vida e porque é o tipo de cefaleia mais frequente nas consultas. É também na área da enxaqueca que têm surgido maiores inovações terapêuticas que terão o respetivo destaque. $O$ desenvolvimento de novos fármacos na enxaqueca está a fazer-se a um ritmo muito rápido pelo que é expectável que brevemente seja necessário atualizar estas recomendações.

Neste manual não considerámos o grande grupo das cefaleias secundárias (com uma única exceção: as cefaleias secundárias a uso excessivo de medicamentos, pela sua relevância e estreita relação com as outras cefaleias primárias), já que nessas cefaleias o tratamento da dor de cabeça depende da causa subjacente na maioria dos casos.

Abordaremos também situações particulares em que a decisão terapêutica pode ser especialmente difícil: é o caso da população pediátrica, dos idosos ou das grávidas; serão ainda equacionadas as questões das interações medicamentosas mais importantes.

\section{PRINCÍPIOS GERAIS DA TERAPÊUTICA DAS CEFALEIAS}

\section{Princípios gerais de abordagem/plano terapêutico}

1 - Estabelecer o diagnóstico. Apenas perante um diagnóstico correto a terapêutica será bem-sucedida. Será aliás pertinente que nos questionemos, perante a refratariedade de uma cefaleia, se o diagnóstico terá sido bem estabelecido: o doente tem apenas um tipo de cefaleia? Tem outras doenças que possam contribuir para a cefaleia (apneia de sono, hipertensão arterial, etc.)?

2 - Fornecer aos doentes noções precisas da doença. Explicar que os exames complementares de diagnóstico são normais nas cefaleias primárias; são solicitados para sabermos que não têm aspetos patológicos e não para fazerem diagnóstico. Esta explicação evita que os exames sejam repetidos sem necessidade. Diferenciar desencadeantes e causa.

\section{3 - Encorajar o doente a identificar e evitar fato-} res desencadeantes como por exemplo: a ingestão de certos alimentos, excesso de cafeína, intervalos grandes entre refeições, ingestão de álcool, situações de stress, esforços físicos, alterações do ritmo do sono, como dormir demais ao fim de semana, relação com contraceção hormonal, menstruação; terapêutica hormonal de substituição na menopausa; esforço físico intenso; postura incorreta durante o sono ou no trabalho.

4 - Abordar a escolha de um tratamento particular, modo de utilização e efeitos indesejáveis expectáveis. Assegurar-se de que o doente percebeu bem o que lhe foi dito tanto em relação à cefaleia como ao tratamento.

Estar atento às expectativas do doente e definir objetivos apropriados, discutindo os benefícios esperados e o tempo que demora a serem atingidos. Envolver ativamente o doente no tratamento, pedindo para preencher corretamente os calendários de cefaleias, salientando a importância que o calendário tem na ajuda no diagnóstico e na monitorização do efeito terapêutico ou na ausência dele. $\bigcirc$ calendário deve ser de fácil preenchimento e explicado previamente como o fazer. Um calendário complicado ou extenso desincentiva o doente a preenchê-lo.

A escolha do tratamento depende da frequência e intensidade das crises, a presença e graduação da incapacidade temporária e a presença de sintomas associados como náuseas e vómitos. Em certas cefaleias como na enxaqueca e cefaleias em salvas não há terapêutica curativa que elimine a cefaleia de vez.

5 - Criar um esquema terapêutico individualizado, considerando a resposta e a tolerância a medicamentos específicos. Considerar comorbilidades. Salientar que a terapêutica deve ser cumprida. $O$ doente já fez algum tratamento de base? Com que fármacos e por quanto tempo? Porque não resultou? Porque abandonou?

De um modo geral e na maioria dos casos, o tratamento deverá ser dividido em sintomático, abortivo, de fase aguda ou da crise e tratamento profilático. O tratamento sintomático consiste na utilização de agentes que revertem, abortam ou reduzem a dor e os possíveis sintomas acompanhantes. A escolha da medicação depende de fatores como a frequência, a intensidade da dor, a presença ou ausência de sintomas acompanhantes como vómitos, o início de ação da medicação, a biodisponibilidade do medicamento, as comorbilidades e doenças coexistentes, os efeitos adversos da medicação e a história prévia dos medicamentos utilizados.

Geralmente o uso da medicação sintomática não deverá exceder 2-3 dias por semana. Poderá ser utilizada isolada ou associada à medicação preventiva. A via de administração é muito importante. Quando as náuseas 
são importantes deve ser feito o uso concomitante de antieméticos. Como a gastroparésia é frequente nas crises de enxaqueca, serão de ponderar as vias rectal, nasal ou parentérica.

tratamento preventivo ou profilático é utilizado para prevenir as crises bem como para reduzir a sua frequência e intensidade. Deverá ser instituído quando as crises forem superiores a determinado número por mês dependendo do tipo de cefaleia em causa, quando a intensidade e a duração das crises justificar o uso da terapêutica preventiva mesmo que as crises sejam pouco frequentes, quando a utilização da medicação sintomática for excessiva em frequência ou dose, quando a medicação sintomática não puder ser utilizada (contraindicação por exemplo) e para potenciar a medicação sintomática. Tal como no tratamento sintomático dever-se-á ter em conta as comorbilidades e os possíveis efeitos adversos.

É muito importante que ao iniciar o tratamento preventivo com fármacos orais, se comece com doses baixas e se aumente gradualmente ("start low and go slow"). A melhoria não é imediata, começando geralmente 4 semanas após o início, havendo de esperar cerca de 8 semanas para certificar que a medicação não é eficaz. A terapêutica preventiva deverá ser mantida pelo menos 6-9 meses antes da redução e suspensão.

\section{6 - Evitar a automedicação e o uso excessivo de} medicação. $\bigcirc$ uso excessivo de analgésicos deverá ser evitado pois é causa da cefaleia por uso excessivo de medicamentos, com crises ocorrendo em mais de 15 dias por mês. A ICHD-3 estabeleceu diferentes limiares para o diagnóstico de diferentes tipos de cefaleia por uso excessivo de medicamentos. $O$ uso excessivo de medicamentos é definido pela ingestão regular de ergotamínicos, triptanos ou combinação de analgésicos ou opioides em pelo menos 10 dias/mês durante pelo menos 3 meses e no caso de analgésicos simples (ex. anti-inflamatórios não esteroides - AINEs e paracetamol) pelo menos 15 dias por mês durante pelo menos 3 meses. A via de administração depende do tipo de cefaleia em causa.

É dever do médico explicar o mecanismo do agravamento da cefaleia devido ao uso excessivo de analgésicos e dever do doente cumprir as nossas diretivas. Só co-responsabilizando o doente no cumprimento da terapêutica se pode obter um bom resultado.

\section{Neuroimagem}

Nas cefaleias agudas os seguintes sintomas/sinais aumentam significativamente a probabilidade de encontrar uma alteração nos estudos imagiológicos:

- Frequência da cefaleia aumentando rapidamente.

- Existência de sinais focais.

- Cefaleia que desperta o doente durante o sono, embora este facto possa ocorrer na enxaqueca e na cefaleia em salvas.

Nas cefaleias não agudas, considerar o estudo neuroimagiológico nos seguintes casos:

- Alterações no exame neurológico

- Características atípicas da cefaleia, cefaleia que não preencha os critérios de enxaqueca ou de outra cefaleia primária ou presença de fator de risco adicional como deficiência imunitária.

O estudo imagiológico não é habitualmente necessário em doentes com enxaqueca e cefaleias de tensão crónica e exame neurológico normal. Frequentemente os exames são pedidos para tranquilizar o doente e não tanto por serem mesmo necessários.

\section{Tratamentos comportamentais e não farmacológicos}

As intervenções não farmacológicas, como o biofeedback (térmico, com EMG) e terapêutica cognitivo-comportamental e técnicas de relaxação são tratamentos com evidência de nível $A$ e grau II de recomendação, nas cefaleias, sobretudo nas cefaleias tipo tensão.

Existem várias revisões sistemáticas com meta-análises sobre os tratamentos psicológicos para as cefaleias, havendo evidência substancial, salientando-se, no entanto, que é necessária mais investigação para aumentar a qualidade da evidência. É de referir que não existem recomendações específicas para se poder escolher a técnica mais apropriada - grau de recomendação II, nível de evidência $C$.

Estas terapêuticas têm menos efeitos adversos que as intervenções farmacológicas e frequentemente com efeito equivalente, mas a taxa de participação mantém-se baixa. Algumas das razões prendem-se com o facto de nem sempre serem acessíveis tanto fisicamente como economicamente, mas também pela não-aceitação por parte dos doentes e de alguns médicos.

Matsuzava e colaboradores identificaram vários fatores psicológicos, tais como, atitudes e crenças, falta de motivação, pouca perceção dos desencadeantes, pouca 
autossuficiência, baixos níveis de aceitação dos desencadeantes; traços de personalidade, doenças psiquiátricas coexistentes e adoção de estilos errados de coping que contribuem à não adesão a estes tipos de tratamento.

A terapêutica cognitivo comportamental (TCC) no sentido lato deve ser usada em paralelo com a terapêutica farmacológica e especialmente em doentes que tenham tendência a usar excessivamente os analgésicos, quando a intensificação da cefaleia está relacionada com o stress, e quando as cefaleias levam a uma incapacidade funcional, ou seja, basicamente nas cefaleias crónicas (frequência $>15$ dias por mês)

Harris e Barry fizeram uma revisão sistematizada de vários estudos, mas os resultados da revisão foram mistos, com alguns estudos sugerindo que a TCC é benéfica no tratamento das cefaleias no geral e da enxaqueca. Contudo foi impossível tirar conclusões definitivas devido a irregularidades metodológicas - grau de recomendação II, nível de evidência $C$.

Mais uma vez para se ter uma boa adesão do doente à terapêutica e um reconhecimento da frequência das dores, da ingestão de analgésicos e dos desencadeantes é importante efetuar diário das cefaleias: registar a frequência, intensidade, fatores desencadeantes, associações com o ciclo menstrual, medicação efetuada e resposta ao tratamento; registar terapêuticas não convencionais efetuadas. A utilização dos calendários é recomendada para encorajar o cumprimento da medicação profilática, para registar o efeito do tratamento, para controlar a utilização excessiva de medicação sintomática e para registar a evolução.

Ajustar fatores de estilo de vida: reduzir a ingestão de cafeína, efetuar exercício físico regularmente, manter padrão de sono regular e evitar "saltar" refeições.

Ainda não foi possível obter recomendações baseadas na evidência em relação à hipnose, acupuntura, estimulação elétrica transcutânea de nervo, manipulação cervical osteo ou quiroprática para a terapêutica aguda ou preventiva das cefaleias.

Numa revisão da Cochrane sobre a acupuntura na cefaleia tipo tensão episódica frequente ou crónica a sua efetividade é controversa. Em II ensaios, a acupuntura foi comparada com tratamento agudo ou tratamento de rotina apenas em 2 ensaios grandes, mas nenhum foi cego e os doentes tinham frequência de cefaleias diferentes à partida. Os resultados a longo prazo (para lá dos 4 meses) não foram investigados. Em 7 ensaios a acupuntura foi comparada com acupuntura "branca" sendo que $51 \%$ dos submetidos às acupunturas verdadeiras tiveram uma redução de pelo menos $50 \%$ das cefaleias e $43 \%$ na acupuntura branca, sendo que o resultado aos 6 meses foi similar (grau de recomendação Ila, nível de evidência A).

Quando a acupuntura foi comparada com fisioterapia, massagem e exercício em 4 ensaios de qualidade fraca a moderada (elevado risco de enviesamento), não se encontrou uma superioridade significativa para a acupuntura.

Em relação à mindfulness foram realizados 5 ensaios controlados com um total de 185 participantes com diagnósticos de cefaleias de tipo tensão, enxaqueca e amostras mistas. Não se verificou uma melhoria na frequência das cefaleias nem na duração ou intensidade (grau de recomendação llb, evidência de nível A).

\section{Neuromodulação não invasiva}

A neuromodulação não invasiva altera a atividade nervosa através da estimulação dos nervos. Esta tecnologia está a emergir como uma alternativa prática e segura às intervenções farmacológicas convencionais no tratamento da enxaqueca e da cefaleia em salvas. Recentemente foi publicada uma revisão dos estudos contemplando as três formas de neuromodulação não invasiva com autorização regulamentar na Europa e nos Estados Unidos da América para o tratamento sintomático e preventivo da enxaqueca e da cefaleia em salvas: a estimulação não invasiva do nervo vago, a estimulação magnética transcraniana de pulso único e a estimulação externa do nervo trigémeo - grau lla, nível de evidência $A$.

Os estudos da estimulação não invasiva do nervo vago demonstraram a adesão mais consistente às recomendações disponíveis. Nos respetivos capítulos estão disponíveis recomendações específicas para o tratamento da enxaqueca e da cefaleia em salvas com dispositivos.

\section{Terapêuticas alternativas e complementares}

Os doentes com enxaqueca estão a utilizar cada vez mais terapêuticas alternativas e complementares, em que os produtos nutracêuticos (de "nutrição" e indústria "farmacêutica") são considerados terapêuticas biológicas. De acordo com as recomendações existentes, tem evidência de nível B na prevenção da enxaqueca o emprego de riboflavina, coenzima Q10, magnésio, "feverfew" (Tanacetum parthenium) ou matricária, ácidos gordos polinsaturados ómega 3 e "buterbur" (Petasites 
hybridus). Não é recomendada a utilização deste último agente dada a sua potencial hepatotoxicidade. A evidência a favor ou contra a sua utilização é limitada, mas estes agentes poderão constituir uma opção nos doentes em que os efeitos adversos constituem o aspeto mais importante na eleição do tratamento preventivo. A qualidade de evidência nesta área é pobre.

\section{Definição de cefaleia refratária}

- Insucesso do tratamento médico bem conduzido, definido pela não resposta ao tratamento médico em doses ótimas e/ou efeito terapêutico não sustentado e/ou presença de efeitos adversos e/ou noção de contraindicação para o tratamento.

- Falência de três medicamentos em doses eficazes e durante o tempo recomendado.

\section{ENXAQUECA}

\subsection{MEDIDAS GERAIS}

A enxaqueca manifesta-se por crises recorrentes de cefaleias, alternando com períodos livres de sintomas. A cefaleia é tipicamente pulsátil, de intensidade moderada a severa e pode-se acompanhar de múltiplos sintomas. Os seus critérios de diagnóstico estão bem definidos na $3^{\mathrm{a}}$ edição da Classificação Internacional de Cefaleias (ICHD-3) assim como os seus principais subtipos.'

O tratamento da enxaqueca é um tratamento integrado e assenta em três pilares: medidas gerais não farmacológicas, tratamento agudo sintomático e tratamento preventivo nos casos em que isso se justifique. $O$ tratamento sintomático visa encurtar as crises quando elas surgem e o tratamento preventivo, tem como objetivo a redução da frequência, intensidade e duração das crises e consequente redução da incapacidade resultante. $\bigcirc$ tratamento sintomático e o preventivo são geralmente farmacológicos embora possam ser utilizados métodos não farmacológicos como terapias cognitivas comportamentais ou neuroestimuladores externos alguns dos quais já disponíveis no nosso país.

Todos os doentes com enxaqueca, independentemente do número e intensidade das suas crises devem ser esclarecidos sobre a natureza da enxaqueca e dos seus sintomas, aconselhados sobre o que a poderá melhorar e envolvidos ativamente no seu tratamento. $O$ esclarecimento e aconselhamento dos doentes é uma etapa fun- damental na consulta e absolutamente necessária para o sucesso de qualquer estratégia terapêutica. Os doentes devem ser tranquilizados sobre a natureza benigna da sua doença, mas alertados para os riscos de cronificação decorrente de uma utilização excessivamente frequente dos tratamentos sintomáticos.

Deve aconselhar-se a modificação do estilo de vida e a adoção de hábitos de vida saudável. ${ }^{2,3}$ Um doente com enxaqueca deve procurar dormir o número de horas suficiente e ter horários regulares de sono, evitar o jejum prolongado, ter uma alimentação variada e saudável, não fumar, ingerir a quantidade apropriada de água, evitar o excesso de cafeína, praticar exercício físico regularmente e evitar o stress e a ansiedade. A adoção de um estilo de vida saudável com o cumprimento de horários regulares (sono e alimentação) e a prática de exercício físico de modo regular poderá estar associada a redução da frequência e intensidade das crises. ${ }^{4}$

De igual modo devem ser orientados sobre eventuais fatores desencadeantes das crises e sua evicção nos casos em que sejam relevantes e em que se justifique. Os fatores precipitantes mais frequentes são: o stress, a alterações do sono, estímulos ambientais (como condições atmosféricas particulares e exposição a estímulos visuais ou olfativos), o período menstrual e flutuações dos níveis das hormonas femininas e a ingestão de bebidas alcoólicas em especial o vinho tinto. ${ }^{5,6}$

A enxaqueca associa-se a múltiplas comorbilidades que concorrem muitas vezes para o agravamento da própria enxaqueca; é o caso da depressão, da ansiedade e das perturbações do sono. Estas comorbilidades deverão ser concomitantemente abordadas com opções terapêuticas dirigidas, farmacológicas ou não, de modo a se conseguir o controlo efetivo da enxaqueca.

\subsection{TRATAMENTO SINTOMÁTICO DA CRISE DE ENXAQUECA}

\section{Definição}

A enxaqueca é caracterizada por episódios autolimitados de cefaleia, com duração de 4 a 72 horas, de intensidade moderada ou grave, habitualmente unilateral, podendo ser bilateral num terço dos doentes. Além da cefaleia, manifesta-se com uma panóplia de outros sinais e sintomas: náuseas (80\%), vómitos (40\%-50\%), fotofobia (60\%), fonofobia (50\%) e osmofobia (10\%). Sinais 
disautonómicos são comuns. Por vezes a enxaqueca é muito frequente, podendo assumir critérios de enxaqueca crónica.'

\section{Recomendações}

\section{Terapêutica não farmacológica}

Relativamente ao tratamento não farmacológico, não existem dados consistentes.

A evidência no uso de acupuntura na crise de enxaqueca é de nível C. ${ }^{2,3}$

Relativamente aos estimuladores externos, o e-TNS $\left(\right.$ Cefaly $\left.^{\circledR}\right)$ tem um nível de evidência $C{ }^{4}$

A neuromodulação elétrica remota (REN) tem um nível de evidência C. ${ }^{4,5}$ Trata-se de um neuroestimulador controlado à distância por um smartphone.

\section{Terapêutica farmacológicaca}

I. Vários fármacos são eficazes no tratamento das crises de enxaqueca. A seleção de um em detrimento de outro deve basear-se no doente: aspetos clínicos, comorbilidades e preferências.

2. Nas crises ligeiras a moderadas, e eventualmente nas severas, os fármacos indicados são os anti-inflamatórios não esteroides (AINEs), entre os quais o ibuprofeno, o naproxeno, o diclofenac e o ácido acetilsalicílico (nível de evidência A).

3. No caso de resposta fraca ou ausência de resposta e nas crises severas, dever-se-ão utilizar os triptanos (nível de evidência $A$ ).'

4. Opióides, barbitúricos e combinações de analgésicos contendo qualquer um destes fármacos, não devem ser escolhidos como tratamentos de primeira linha - além de serem menos eficazes do que as outras opções, a sua administração frequente aumenta o risco de desenvolvimento de cefaleia por uso excessivo de medicação.

5. O ceterolac iv, $30 \mathrm{mg}$, podendo subir-se a dose para $60 \mathrm{mg}$, é eficaz (grau evidência A). ${ }^{9}$

6. A evidência do papel dos corticosteroides na crise aguda de enxaqueca não está demonstrada (nível de evidência B-C) embora amplamente divulgada e com dados contraditórios. ${ }^{10}$

\section{Tratamento das náuseas}

A náusea é um sintoma frequentemente associado à enxaqueca e pode ser bastante incapacitante, influenciando também a escolha da via de administração de analgésicos.

Em doentes com náusea ligeira, náusea agravada pela ingestão de líquidos ou quando o aporte de líquidos é difícil, é dada preferência à utilização de zolmitriptano na formulação orodispersível.

Em doentes com náusea moderada, pode ser utilizado um antiemético em combinação com um AINE ou triptano. A metoclopramida $10 \mathrm{mg}$ é o antiemético com melhor evidência de eficácia, podendo adicionalmente reduzir a estase gástrica e melhorar a absorção dos outros fármacos pelo seu efeito procinético. A domperidona $10 \mathrm{mg}$, apesar de ser menos eficaz, tem a vantagem de não causar efeitos extrapiramidais.

Em doentes com náusea marcada ou que vomitam precocemente no decorrer da evolução de uma crise de enxaqueca, deve ser considerada a utilização de sumatriptano 6 mg subcutâneo ou zolmitriptano 5 mg na formulação de spray nasal.

\section{Tratamentos farmacológicos específicos para as crises de enxaqueca ${ }^{6-8}$}

\section{Ergotamina $^{6}$}

Não há consenso para a utilização de ergotamina na prática clínica, atendendo aos resultados contraditórios de alguns ensaios. No geral, considera-se que doentes que tenham sido medicados com ergotamina no passado e que tenham uma resposta satisfatória, na ausência de contraindicações à sua utilização ou sinais de abuso, poderão potencialmente continuar com este fármaco. Em casos de doentes com crises de duração $>48$ horas ou com recorrência frequente, a ergotamina pode ser útil. Em Portugal existe um único medicamento contendo ergotamina.

A ergotamina está contraindicada em mulheres grávidas ou que planeiam engravidar, na doença vascular periférica, doença coronária, hipertensão não controlada, acidente vascular cerebral (AVC) e insuficiência renal ou hepática. Deve ser evitada em casos de enxaqueca hemiplégica, enxaqueca com aura do tronco cerebral e enxaqueca com aura prolongada. 


\section{Triptanos (Tabelas 3.2.1 e 3.2.2)}

Os triptanos são os mais eficazes e específicos para o tratamento da enxaqueca. ${ }^{6-8,11-13} \mathrm{~A}$ sua eficácia é de $60 \%$ e a recorrência cifra-se entre 15\% e $40 \%$.

- A ausência de resposta a um triptano não implica a ausência de resposta a outro.

- O sumatriptano sc é o mais eficaz e o de mais rápida atuação. ${ }^{11,12,14}$

- Dos orais, destacam-se o rizatriptano e o eletriptano como os mais eficazes. ${ }^{6,7,13}$

- O eletriptano e o almotriptano são o que têm meIhor perfil de efeitos secundários. ${ }^{6,7,13}$

- O naratriptano e o frovatriptano são os que têm maior semivida.

- A associação dos triptanos com o naproxeno potencia o efeito terapêutico., ${ }^{7}$
- A administração dos triptanos deve ser precoce para uma maior eficácia. ${ }^{7}$

- O número de tomas de terapêutica abortiva (das crises) deve ser limitado a $<10$ dias por mês para evitar o desenvolvimento de cefaleia por uso excessivo de medicamentos.'

No caso de recorrência (reaparecimento ou agravamento da cefaleia num período de 2 a 24 horas), que surge em $15 \%$ a $40 \%$ dos doentes, deve ser administrada uma segunda dose do triptano ${ }^{16}$ ou, em alternativa, utilizar inicialmente a combinação de um triptano com um AINE de longa acção. Este problema ocorre mais frequentemente com os triptanos com menor semivida. Se a primeira dose não for eficaz, não se espera eficácia com uma segunda dose, pelo que se deve usar um analgésico não opióide.

Tabela 3.2.1. Tratamentos farmacológicos específicos para as crises de enxaqueca

\begin{tabular}{|c|c|c|c|}
\hline Triptano & Dose & Via & Comentários $^{7}$ \\
\hline \multicolumn{4}{|c|}{ Início de acção rápido e curta duração } \\
\hline Sumatriptano & $\begin{array}{l}6 \mathrm{mg} \\
50 / 100 \mathrm{mg}\end{array}$ & $\begin{array}{l}\text { Sc } \\
\text { Oral }\end{array}$ & $\begin{array}{l}\text { Parestesias, rubor, rigidez cervical transitória, desconforto pré-cordial } \\
\text { ou mandibular }\end{array}$ \\
\hline Eletriptano & $20 / 40 / 80 \mathrm{mg}$ & Oral & $\begin{array}{l}\text { Bem tolerado } \\
\text { Exclusivamente metabolizado pelo sistema CYP3A4 - interacções } \\
\text { medicamentosas }\end{array}$ \\
\hline Rizatriptano & $5 / 10 \mathrm{mg}$ & Oral & $\begin{array}{l}\text { Parestesias, rubor, rigidez cervical transitória, desconforto pré-cordial } \\
\text { ou mandibular, palpitações. }{ }^{\star \star}\end{array}$ \\
\hline Almotriptano & $12,5 \mathrm{mg}$ & Oral & Bem tolerado \\
\hline Zolmitriptano & $\begin{array}{l}5 \mathrm{mg} \\
2,5-5 \mathrm{mg}\end{array}$ & $\begin{array}{l}\text { Spray nasal } \\
\text { Oral }\end{array}$ & $\begin{array}{l}\text { Parestesias, rubor, rigidez cervical transitória, desconforto pré-cordial } \\
\text { ou mandibular, palpitações. } \\
\text { Contraindicado em doentes com síndrome de Wolf-Parkinson-White }\end{array}$ \\
\hline \multicolumn{4}{|c|}{ Início de acção lento e longa duração } \\
\hline Naratriptano & $2,5 \mathrm{mg}$ & Oral & Bem tolerado \\
\hline Frovatriptano & $2,5 \mathrm{mg}$ & Oral & Bem tolerado \\
\hline
\end{tabular}

* Se resposta insuficiente, associar um AINE (naproxeno $1000 \mathrm{mg}$ ) ao triptano

** Propranolol aumenta os níveis de rizatriptano (usar $5 \mathrm{mg}$ )

\section{Efeitos adversos dos triptanos}

Sendo o mecanismo de acção semelhante, esperam-se efeitos adversos semelhantes. Estes são raros. A ocorrência de desconforto pré-cordial e parestesias nos membros é relativamente comum (7\%), mas não se encontra associada ao aumento do risco de eventos isquémicos cardiovasculares. ${ }^{7}$ Deve evitar-se a associação aos fármacos serotoninérgicos. ${ }^{17}$
Os doentes com enxaqueca com aura só devem tomar o triptano quando a aura desaparece, embora ultimamente se tenha questionado esta prática.

Do mesmo modo, recentemente há vários estudos que esclarecem que os triptanos podem ser usados na enxaqueca hemiplégica quando os AINEs falham. ${ }^{15}$ 
Tabela 3.2.2. Contraindicações ao uso de triptanos ${ }^{6,7}$

\begin{tabular}{|l|}
\hline HTA não controlada \\
\hline Doença coronária, enfarte do miocárdio, angina de peito \\
\hline Doença arterial periférica, doença de Raynaud \\
\hline AIT ou AVC \\
\hline Colite isquémica \\
\hline Gravidez, lactação \\
\hline Insuficiência hepática ou renal grave \\
\hline Enxaqueca hemiplégica \\
\hline Enxaqueca com aura do tronco cerebral \\
\hline $\begin{array}{l}\text { Tratamento com IMAO (deve suspender o IMAO } 2 \\
\text { semanas antes) }\end{array}$ \\
\hline $\begin{array}{l}\text { Ocorrência de sobredosagem (no caso de associação ao } \\
\text { propranolol) }\end{array}$ \\
\hline $\begin{array}{l}\text { Utilização de outro triptano ou ergotamina nas } 24 \text { horas } \\
\text { prévias }\end{array}$ \\
\hline Alergia às sulfonamidas* \\
\hline
\end{tabular}

* Nestes casos podem utilizar-se o rizatriptano, frovatriptano ou zolmitriptano.
Tratamentos farmacológicos não específicos para as crises de enxaqueca ${ }^{18-21}$ (Tabela 3.2.3)

\section{Paracetamol}

A eficácia do paracetamol como fármaco de primeira linha é controversa, não tendo sido suportada por alguns ensaios clínicos, ${ }^{7}$ mas tendo demonstrado eficácia noutros ${ }^{18}$ (nível de evidência B). A sua utilização deve ser limitada a menos de 14 dias por mês ou menos de 10 dias por mês se em combinação com outros fármacos, para diminuir o risco de cefaleia por uso excessivo de medicamentos. ${ }^{7}$

\section{AINEs}

São amplamente utilizados para o tratamento agudo da enxaqueca, atuando sobretudo através da inibição da inflamação neurogénica e da reversão da sensibilização central associada à enxaqueca.

Os AINEs estão contraindicados em doentes com úlcera péptica, doença intestinal inflamatória, bypass gástrico, alergia à aspirina, insuficiência renal e uso concomitante de anticoagulantes. $O$ seu uso deve ser infe-

Tabela 3.2.3. Analgésicos e AINES ${ }^{18-21}$

\begin{tabular}{|l|l|l|l|}
\hline Fármaco & Dose $\mathbf{( m g )}$ & Via & Comentário \\
\hline Paracetamol & 1000 & Oral & $\begin{array}{l}\text { Semivida curta (2-3 horas): necessidade de doses adicionais } \\
\text { Menos efeitos secundários gastrointestinais } \\
\text { Sem interferência na funão plaquetária }\end{array}$ \\
\hline AAS/Acetilsalicilato lisina & 1000 & Oral & $\begin{array}{l}\text { Semivida relativamente longa (6 horas) } \\
\text { Formulação efervescente tem início de acção mais rápido } \\
\text { Pode-se associar metoclopramida }\end{array}$ \\
\hline Ibuprofeno & $400-600$ & Oral & $\begin{array}{l}\text { Rápido início de acção } \\
\text { Semivida curta (2 horas): necessidade de doses adicionais } \\
\text { Doses maiores não demonstraram maior eficácia do que os } \\
\text { 400mg }\end{array}$ \\
\hline Naproxeno & $500-550$ & Oral & $\begin{array}{l}\text { Início de acção mais lento } \\
\text { Longa duração de acção (semivida de 14 horas) } \\
\text { Eficaz no tratamento de crises moderadas a graves } \\
\text { Melhor perfil de segurança cardiovascular }\end{array}$ \\
\hline Diclofenac potássico & $50-100$ & Oral & $\begin{array}{l}\text { Baixa eficácia } \\
\text { Rápido início de acção } \\
\text { Semivida curta (2 horas): necessidade de doses adicionais }\end{array}$ \\
\hline $\begin{array}{l}\text { AAS + paracetamol } \\
+ \text { cafeína }\end{array}$ & $250+250+65$ & Oral & $\begin{array}{l}\text { Maior eficácia do que os seus componentes isoladamente } \\
\text { Maior risco de cefaleia por uso excessivo de medicamentos }\end{array}$ \\
\hline
\end{tabular}

* Outros AINEs ou inibidores da COX poderão ser eficazes, mas, pela falta de evidência, não são rotineiramente recomendados

rior a 14 dias, para diminuir o risco de cefaleia por uso excessivo de medicamentos.

\section{Tratamento da fase aguda no serviço de urgência ${ }^{7,8}$ (Tabelas 3.2.4 e 3.2.5)}

Habitualmente, doentes que recorrem ao serviço de urgência nas crises de enxaqueca já tentaram fármacos orais sem sucesso ou têm náuseas e vómitos significati- vos, pelo que se assume que a terapêutica oral não será eficaz.

O sumatriptano via sc é eficaz e de ação rápida, no controlo da dor, náusea, fono e fotofobia. ${ }^{11,12}$

O uso de zolmitritano em spray nasal, em detrimento do sumatriptano por essa via, que não existe em Portugal, é também uma opção se associado a um AINE. ${ }^{11,12}$ 
A metoclopramida iv deve ser considerada como terapêutica de primeira linha no serviço de urgência, tendo alguns ensaios sugerido um efeito primário na enxaqueca, além das suas propriedades antieméticas.

A associação da metoclopramida com ácido acetilsalicílico (AAS) e acetato de lisina, paracetamol ou um AINE é a opção mais generalizada.

O cetorolac ev é um fármaco eficaz (grau evidência A).

Nos casos resistentes e no estado de mal migranoso usa-se também a clorpromazina e corticoides ev. Para se considerar a fármaco-resistência como verdade devemos sempre otimizar a dose da medicação e via de administração. Também nas situações de contraindicações aos triptanos os corticoides via ev são uma alternativa terapêutica sustentável e eficaz.

A hidratação, embora não seja farmacológica é premente no serviço de Urgência.

Tabela 3.2.4. Fármacos de utilização nas crises de enxaqueca no serviço de urgência

\begin{tabular}{|l|}
\hline $\begin{array}{l}\text { Acetilsalicilato de lisina } 1000 \mathrm{mg} \text { iv com ou sem } \\
\text { metoclopramida (ou outro antagonista dopaminérgico) }\end{array}$ \\
\hline Sumatriptano $6 \mathrm{mg} \mathrm{sc}$ \\
\hline Triptano em spray nasal + AINE rectal \\
\hline Clopromazina iv $0,1 \mathrm{mg} / \mathrm{kg}$ \\
\hline
\end{tabular}

* Os vários fármacos poderão associar-se, mas os efeitos adversos serão potenciados

Tabela 3.2.5. Fármacos sem clara demonstração de eficácia

\begin{tabular}{|l|}
\hline Diclofenac sódico oral $50,100 \mathrm{mg}$ \\
\hline Diclofenac sódico im \\
\hline Metamizol oral \\
\hline Metamizol ev \\
\hline Naproxeno oral \\
\hline Cetorolac oral \\
\hline Celecoxib oral \\
\hline
\end{tabular}

\section{Novos tratamentos da crise de enxaqueca ${ }^{22-23}$}

Dadas as contraindicações dos triptanos, foram desenvolvidos novos fármacos que não provocam vasoconstrição, para obviar esse problema, ainda em estudo. $22-23$

Os gepants (ubrogepant e rimegepant) e lasmiditano não causam vasoconstrição.

Os estudos a decorrer atualmente sugerem um benefício dos gepants e ditanos quando comparados com o placebo. Em qualquer dos casos, não há estudos comparativos com fármacos ativos.

Tabela 3.2.6. Novos tratamentos da crise de enxaqueca

\begin{tabular}{|l|l|l|}
\hline Fármaco & $\begin{array}{l}\text { Mecanismo de } \\
\text { acção }\end{array}$ & Local de acção \\
\hline $\begin{array}{l}\text { Ubrogepant } \\
50 \text { e } 100 \mathrm{mg}\end{array}$ & Inibidor CGRP & \\
\hline Rimegepant & Inibidor CGRP & \\
\hline $\begin{array}{l}\text { Lasmiditan } \\
50 \text { e } 100 \mathrm{mg}\end{array}$ & Agonista 5-HT1 & $\begin{array}{l}\text { Acção central e } \\
\text { periférica }\end{array}$ \\
\hline
\end{tabular}

\subsection{TRATAMENTO PREVENTIVO DA ENXAQUECA EPISÓDICA}

\section{Enquadramento, indicações e objetivos da terapêutica}

A enxaqueca episódica (EE) constitui a forma mais comum de enxaqueca. Apresenta dois tipos principais: enxaqueca com aura e enxaqueca sem aura.' A incapacidade resultante da enxaqueca está diretamente relacionada com a frequência e a intensidade das crises. Abordaremos neste capítulo o tratamento preventivo da EE (com e sem aura) e no capítulo seguinte o tratamento da enxaqueca crónica (EC), aquela em que há mais de I 5 dias por mês de cefaleias,' pois merecem uma abordagem diferenciada.

A instituição da terapêutica preventiva, na $E E$, não está indicada em todos os doentes; essa indicação irá depender da frequência, duração e intensidade das crises. Deve ser alvo de prevenção tanto a enxaqueca com aura como a sem aura.

Com a terapêutica preventiva, não se obtendo uma cura, pretende-se melhorar a qualidade de vida e de saúde do indivíduo e reduzir o agravamento progressivo do número de crises, com risco de progressão para enxaqueca crónica, de mais difícil tratamento e associada a pior qualidade de vida.

Os objetivos do tratamento preventivo da enxaqueca são:

I. Reduzir a frequência (em mais de 50\%), a intensidade e a duração das crises

2. Reduzir os sintomas acompanhantes

3. Aumentar a resposta à terapêutica aguda evitando a escalada de tratamentos sintomáticos

4. Melhorar a função e diminuir a incapacidade associada às crises 
5. Reduzir os custos (pessoais e socioeconómicos) associados à enxaqueca

6. Aumentar a qualidade de vida

7. Evitar a progressão da doença (cronificação)

8. Capacitar o doente no controlo da sua doença.

A indicação para início de terapêutica irá depender da frequência com que as crises surgem e da incapacidade e sofrimento por elas provocada. ${ }^{3}$ Outros fatores também a ter em conta na seleção de doentes para profilaxia é a resposta ao tratamento agudo e o risco de evolução para enxaqueca crónica ou para cefaleia por uso excessivo de analgésicos.

A incapacidade resultante das crises de enxaqueca, para além do que é relatado pelo doente, deve ser quantificada do modo mais rigoroso e estandardizado possível através de utilização de escalas de avaliação de impacto sobre a vida profissional, social e familiar. Também na documentação da resposta à terapêutica preventiva deve-se utilizar o calendário das crises e as escalas de avaliação do impacto da enxaqueca, como por exemplo a escala MIDAS 4 (Migraine Disability Assessment Scale).

A SPC recomenda a utilização de terapêutica preventiva/profilática na enxaqueca nas seguintes situações:

I) Crises frequentes (frequência superior a 2 crises ou 4 dias de enxaqueca por mês).

2) Crises com duração e intensidade suficiente para interferirem de forma significativa com as atividades de vida diária (apesar da terapêutica aguda corretamente instituída).

3) Quando a terapêutica aguda não é eficaz ou produz efeitos adversos intoleráveis ou existem contraindicações à sua utilização.

4) Quando existe risco de uso excessivo de tratamento agudo (quando é utilizado mais do que duas vezes por semana) e de cronificação (crises muito frequentes ou com agravamento progressivo).

5) Preferência do doente (mesmo que menor frequência das crises).

Para além destas situações a terapêutica preventiva deve também ser instituída em certos tipos raros de enxaqueca como a enxaqueca hemiplégica, a enxaqueca com aura do tronco cerebral, a enxaqueca com aura prolongada e quando já tenha ocorrido enfarte relacionado com a enxaqueca, mesmo que a frequência das crises seja menor, mas em que poderá haver risco de sequelas neurológicas permanentes. ${ }^{2}$

Antes de se iniciar qualquer tratamento preventivo é importante discutir com o doente as expectativas realistas da eficácia e o prazo expectável para atingir essa resposta já que todos os preventivos têm um tempo de latência até iniciarem o seu efeito.

É considerada eficácia do tratamento preventivo da enxaqueca ${ }^{2}$ uma redução em $50 \%$ da frequência dos dias com cefaleia. São consideradas também uma melhoria da resposta ao tratamento sintomático e uma redução da necessidade do seu consumo, bem como a redução da duração e da intensidade das crises com melhoria da qualidade de vida e diminuição da incapacidade associada.

\subsubsection{Tratamento não farmacológico}

É preconizada a utilização de métodos não farmacológicos para tratamento da enxaqueca, nomeadamente na presença de algumas comorbilidades (sobretudo psiquiátricas) como a terapia cognitivo-comportamental, o retro-controlo biológico (biofeedback) e outras técnicas de relaxamento. ${ }^{5,6}$ Segundo a American Headache Society $(\mathrm{AHS})^{2}$ estes tratamentos estarão indicados nos doentes que preferem intervenções não farmacológicas, apresentem contraindicação, resposta insuficiente ou baixa tolerância aos medicamentos, mulheres grávidas ou a amamentar ou que planeiem engravidar ou ainda pessoas que apresentem stress significativo ou estratégias inadequadas para lidar com o stress. No entanto, segundo uma recente revisão da Cochrane, ${ }^{7}$ não há evidência de que os tratamentos psicológicos afetem a frequência das crises ou melhorem a enxaqueca a curto ou longo prazo, pelo que a utilização destes métodos não pode ser recomendada de um modo sistematizado (grau de recomendação II, nível de evidência A). ${ }^{8}$

Também a acupuntura (cuja efeito depende muito da perícia do técnico) tem evidência que reduz a frequência das crises de enxaqueca ${ }^{9}$ mas a evidência nos ensaios clínicos das diferenças em relação à acupuntura 'branca' (sham) é de fraca qualidade (grau de recomendação II, evidência de nível $\mathrm{A}) .^{10} \mathrm{~A}$ homeopatia não tem qualquer evidência da sua eficácia na enxaqueca (grau de recomendação llb, nível C) assim como também não há evidência robusta da eficácia da manipulação espinhal e da fisioterapia.

\section{Neuromodulação não invasiva}

A neuromodulação não invasiva através da estimulação transcutânea de nervos poderá constituir uma alternativa não farmacológica para o tratamento preventivo da enxaqueca. Os neuroestimuladores externos podem ser 
utilizados como terapêutica única ou em associação com o tratamento farmacológico, em doentes que falham ou não tolerem fármacos, mas também poderão ser de primeira linha nos doentes que não desejem fazer prevenção farmacológica ou que apresentem contraindicações para a sua administração como por exemplo as mulheres grávidas e eventualmente a população adolescente. "

A heterogeneidade dos métodos utilizados na realização de ensaios clínicos torna difícil a adoção de orientações claras sobre a utilidade da sua utilização baseada na evidência.

No nosso país temos disponíveis o estimulador externo supraorbitário do nervo trigémeo $\left(\right.$ Cefaly $\left.^{\circledR}\right)$ e o estimulador transcutâneo do nervo vago (gammaCore ${ }^{\odot}$ ).

O estimulador supraorbitário, através de um elétrodo adesivo na região frontal emite estímulos elétricos transcutâneos para os ramos supraorbitários e supratrocleares do nervo oftálmico. Está aprovado pelas autoridades europeias e nacional para o tratamento da enxaqueca episódica. Foi avaliado em 3 ensaios ${ }^{12,13}$ utilizando um único protocolo de estimulação com aplicação diária de 20 minutos durante 3 meses; no total foram incluídos 194 doentes. Em todos os estudos reduziu a frequência das crises (em mais de 50\%) mas apenas um estudo foi duplamente cego e utilizou 'sham' pelo que não há ainda evidência suficiente para permitir recomendar a sua utilização generalizada (grau de recomenda- ção lla, nível evidência B).

O estimulador externo vagal, aplicado a nível cervical e estimulando por via transcutânea o nervo vago, está também aprovado pelas autoridades europeias para tratamento de cefaleias. A estimulação elétrica vagal, em modelos animais, tem efeitos analgésicos ao reduzir a atividade dos neurónios dos feixes espinotalâmicos e do núcleo do trigémeo. ${ }^{14}$ Num estudo recente com mais de 400 doentes, duplamente cego para tratamento preventivo na enxaqueca episódica não foi possível demonstrar superioridade em relação ao 'sham, ${ }^{15}$ em parte devido a problemas metodológicos e técnicos.

\subsubsection{Tratamento farmacológico}

\section{A. Fármacos preventivos orais}

\section{Regras gerais}

Dispomos de múltiplos fármacos para profilaxia da enxaqueca (Tabela 3.3.1). Os fármacos orais com eficácia demonstrada na profilaxia da EE são utilizados há várias décadas, são de baixo custo económico e considerados tratamentos de primeira linha.

Todos os fármacos orais utilizados na profilaxia da enxaqueca foram desenvolvidos para outras indicações pelo que apresentam frequentes efeitos secundários e contraindicações que podem limitar o seu uso na prática clínica (Tabela 3.3.2).

Tabela 3.3.1. Fármacos preventivos da enxaqueca e níveis de evidência ${ }^{8}$. Adaptado de ${ }^{2}$

\begin{tabular}{|c|c|c|c|}
\hline \multirow[b]{2}{*}{ Fármacos orais } & \multicolumn{3}{|c|}{ Níveis de Evidência } \\
\hline & Nível A & Nível B & Nível C \\
\hline \multirow[t]{2}{*}{ Antiepilepticos } & Valproato de sódio & Gabapentina & \\
\hline & Topiramato & & \\
\hline \multirow[t]{3}{*}{ Beta-bloqueantes } & Metoprolol & Nadolol & Nebivolol \\
\hline & Propranolol & Atenolol & Pindolol \\
\hline & & Bisoprolol & \\
\hline \multirow[t]{2}{*}{ Antidepressivos } & Amitriptilina & Venlafaxina & \\
\hline & & Fluoxetina & \\
\hline Antagonistas Canais Cálcio & Flunarizina & & Verapamilo \\
\hline Antagonistas dos recetores Angiotensina & & & Candesartan \\
\hline Fármacos Injetáveis & Toxina botulínica (apenas EC) & Bloqueios anestésicos & \\
\hline Amc anti receptor CGRP & Erenumab & & \\
\hline \multirow[t]{3}{*}{ Amc anti CGRP } & Fremanezumab & & \\
\hline & Galcanezumab & & \\
\hline & Eptinezumab & & \\
\hline
\end{tabular}


Tabela 3.3.2. Fármacos preventivo orais - dosagem, efeitos adversos e contraindicações. Adaptado de ${ }^{3}$

\begin{tabular}{|c|c|c|c|}
\hline Fármaco & Dose & Precauções/Contraindicações & Principais reações adversas \\
\hline $\begin{array}{l}\text { Antagonistas dos } \\
\text { recetores Beta - } \\
\text { adrenérgicos }\end{array}$ & & $\begin{array}{l}\text { Como grupo } \\
\text { Asma e DPCO, ICC, doença de } \\
\text { Raynaud, isquémia das extremidades, } \\
\text { BAV,DMID, bradiarritmia }\end{array}$ & $\begin{array}{l}\text { Como grupo } \\
\text { Bradicardia, hipotensão, pesadelos, insónia, } \\
\text { depressão, disfunção eréctil, fadiga, alterações } \\
\text { gastrointestinais, dispneia }\end{array}$ \\
\hline Propranolol & $40-160 \mathrm{mg}$ & & \\
\hline Metoprolol & $50-200 \mathrm{mg}$ & & \\
\hline Atenolol & $50-100 \mathrm{mg}$ & & \\
\hline Nadolol & $40-240 \mathrm{mg}$ & & \\
\hline Timolol & $10-60 \mathrm{mg}$ & & \\
\hline \multicolumn{4}{|l|}{$\begin{array}{l}\text { Antagonistas do } \\
\text { Cálcio }\end{array}$} \\
\hline Flunarizina & $5-10 \mathrm{mg}$ & $\begin{array}{l}\text { Gravidez, parkinsonismo, } \\
\text { depressão, obesidade }\end{array}$ & $\begin{array}{l}\text { Sedação, depressão, aumento de peso, } \\
\text { parkinsonismo }\end{array}$ \\
\hline Verapamilo & $240-320 \mathrm{mg}$ & Bradicardia, BAV, hipotensão & Bradicadia, hipotensão, BAV, obstipação \\
\hline Antidepressivos & & $\begin{array}{l}\text { Glaucoma, hipertrofia prostática, } \\
\text { mania/hipomania, hipoglicémia }\end{array}$ & $\begin{array}{l}\text { Sonolência, secura mucosas, aumento de peso, } \\
\text { obstipação, náuseas alterações da visão, arritmia, } \\
\text { retenção urinária, caimbras musculares, disfunção } \\
\text { eréctil, tremor, anorexia, alterações gastrointestinais, } \\
\text { dermopatias, hipotensão ortostática }\end{array}$ \\
\hline Amitriptilina & $10-150 \mathrm{mg}$ & & \\
\hline Doxepina & $25-150 \mathrm{mg}$ & & \\
\hline Fluoxetina & $20-30 \mathrm{mg}$ & & \\
\hline \multicolumn{4}{|l|}{ Antiepilepticos } \\
\hline $\begin{array}{l}\text { Valproato de } \\
\text { sódio }\end{array}$ & $800-1500 \mathrm{mg}$ & $\begin{array}{l}\text { Hepatite, insuficiência hepática, } \\
\text { gravidez, mulher em idade fértil, } \\
\text { discrásia hemorrágica }\end{array}$ & $\begin{array}{l}\text { Sonolência, tremor, queda cabelo, aumento peso, } \\
\text { trombocitopenia, vómitos, pancreatite, dermopatia, } \\
\text { ataxia, encefalopatia, teratogenecidade }\end{array}$ \\
\hline Topiramato & $50-200 \mathrm{mg}$ & $\begin{array}{l}\text { Nefrolitíase, insuficiência renal ou } \\
\text { hepática, miopia grave }\end{array}$ & $\begin{array}{l}\text { Acidose metabólica, glaucoma e miopia aguda, } \\
\text { litíase renal, teratogenecidade, defeito cognitivo, } \\
\text { sonolência, agitação, fadiga, perda de peso, ataxia }\end{array}$ \\
\hline
\end{tabular}

A SPC recomenda que a seleção do preventivo seja baseada na evidência científica da sua eficácia, na experiência prévia do médico e do doente, no tipo de enxaqueca e nas comorbilidades que o doente apresenta, na tolerabilidade e efeitos secundários de cada fármaco, nas contraindicações específicas de cada medicamento, bem como nas possíveis interações com outros fármacos que o doente faça. Deve ainda ter-se em conta se se trata de mulher em idade fértil, grávida ou que planeie engravidar e qual o método anticoncetivo que utiliza. ${ }^{16}$ No final deste manual será abordada a terapêutica das cefaleias nestes grupos.

Não há evidência de vantagem de um ou outro fármaco conforme o subtipo de enxaqueca (com e sem aura). A escolha do preventivo muitas vezes tem em conta o possível benefício de alguns efeitos adversos nas patologias comórbidas da enxaqueca, por exemplo uti- lizar um betabloqueante em doentes hipertensos ou o topiramato em doentes obesos.

Como regras gerais do tratamento preventivo com fármacos orais a SPC recomenda:

I) Iniciar o tratamento com doses baixas e aumentar lenta e progressivamente a dose de modo a minimizar os efeitos secundários e aumentar a adesão à terapêutica. A escalada da dose deve realizar-se até se atingir o efeito terapêutico desejado, a dose alvo pretendida ou surgir intolerabilidade. ${ }^{2,16}$

2) Preferir posologias mais simples com menor número de tomas diárias.

3) Discutir previamente e esclarecer o doente sobre os possíveis efeitos secundários da medicação. Devem-se fornecer instruções sobre estratégias para a sua redução (por exemplo toma noturna em caso 
de sonolência, titulação mais lenta ou reforço hídrico), de modo a evitar o abandono precoce.

4) Permitir tempo necessário (e na dose suficiente) para a medicação exercer o seu efeito. Deve-se aguardar um mínimo de 8 semanas (idealmente até às 12 semanas) na dose habitualmente eficaz para averiguar se uma terapêutica faz ou não efeito; em casos negativos deve então mudar-se de preventivo oral ${ }^{2,16}$ (nível de evidência $\mathrm{C}$ ).

5) A duração do tratamento é variável e individualizada consoante o fármaco selecionado e a resposta à terapêutica. Nos casos em que um fármaco é eficaz, deve ser mantido durante vários meses, no mínimo 4 e habitualmente 6 , podendo se estender até aos 12 meses, após os quais se deve realizar desmame $^{17,18}$ (nível de evidência C).

6) Quando a resposta é parcial ou não se consegue aumentar a dose pelos efeitos secundários poderá ser útil ou mudar de preventivo ou associar preventivos de classes terapêuticas diferentes, ${ }^{2}$ não havendo, no entanto, qualquer evidência científica do benefício desta estratégia. No caso de resposta parcial é possível que a resposta aumente nos 6 a 12 meses seguintes.
I. Bloqueantes beta-adrenérgicos (nível de evidência A)

Os beta-bloqueantes (antagonistas recetores beta-adrenérgicos) foram a primeira classe de preventivos a serem utilizados na enxaqueca e são dos mais frequentemente utilizados. ${ }^{19}$

\section{Mecanismo de acção}

Desconhece-se o mecanismo de ação dos beta-bloqueantes na profilaxia da EE. Em estudos animais verificou-se que o propranolol inibe a onda de depressão alastrante relacionada com a aura e reduz a excitabilidade neuronal cortical. ${ }^{20-22}$ Reverte o aumento da amplitude dos potenciais evocados visuais verificadas nos doentes com enxaqueca, aumento esse atribuído à hiperexcitabilidade cortical típica desta cefaleia. ${ }^{2}$ Não se sabe se há correlação entre este efeito biológico e a eficácia clínica. ${ }^{24}$

\section{Evidência}

Nem todos os bloqueantes beta-adrenérgicos tem a mesma evidência de eficácia. O propranolol e o metoprolol são aqueles com nível de evidência de $\mathrm{A}$ e grau I de recomendação pela maioria das sociedades científicas internacionais ${ }^{2,25}$ (Tabela 3.3.3).

Tabela 3.3.3. Níveis de recomendação da terapêutica com beta-bloqueantes segundo as sociedades científicas. Adaptado de ${ }^{19}$

\begin{tabular}{|c|c|c|c|}
\hline & Nível A & Nível B & Nível C \\
\hline \multirow[t]{2}{*}{ SPC } & Propranolol & & \\
\hline & Metoprolol & & \\
\hline \multirow[t]{3}{*}{ AHS/ AAN } & Propranolol & Nadolol & Nebivolol \\
\hline & Metoprolol & Atenolol & Pindolol \\
\hline & Timolol & & \\
\hline \multirow[t]{2}{*}{ CHS } & Metoprolol & & \\
\hline & Nadolol & & \\
\hline \multirow[t]{2}{*}{ EFNS } & Propranolol & Bisoprolol & \\
\hline & Metoprolol & & \\
\hline
\end{tabular}

SPC - Sociedade Portuguesa Cefaleias, AHS - American Headache Society, AAN - American Academy of Neurology, CHS - Canadian Headache Society, EFNS-- European Federation of Neurological Societies.

O nadolol e o atenolol apresentam nível de evidência B segundo a American Headache Society (AHS), enquanto que o nebivolol, o pindolol e o bisoprolol são consideradas drogas de segunda linha pela European Headache Federation (EHF) por menor evidência de eficácia. ${ }^{10}$

De um modo geral, os ensaios clínicos em que es- tes fármacos foram testados, ocorreram há mais de 20 anos, muitos deles com $n$ baixos e sem utilizar as metodologias aconselhadas pela IHS. ${ }^{26}$ Os beta-bloqueantes mais vezes estudados foram o propranolol (em 74 ensaios) e o metoprolol (em 2 I ensaios); os restantes apenas em I ou 2 ensaios cada. ${ }^{27}$ 
No conjunto dos ensaios o propranolol foi mais eficaz que o placebo às 8 e 12 semanas com evidência de eficácia classificada de alta qualidade: - I,5 dias de cefaleias por mês (95\% IC -2,3 a -0,65), com 4,9 dias em média de cefaleias por mês na baseline. A evidência da eficácia do metoprolol foi de qualidade moderada (- 0,86 dias por mês, 95\% IC - I,4 a 0,34). Em relação a objetivos secundários o propranolol tem maior probabilidade de reduzir as cefaleias em $50 \%$ do que o placebo às 12 semanas.

Existem também vários ensaios comparando o propranolol com outros fármacos que indicam que tem resultados semelhantes, nomeadamente quando comparando com o valproato de sódio ${ }^{28}$ e com o topiramato; com este último apenas para doses de propranolol de 160 mg. ${ }^{29,30}$ Num estudo que comparou o propranolol com metoprolol com eficácias aparentemente semeIhantes o metoprolol apresentou perfil de efeitos secundários mais favorável. ${ }^{3 !}$

\section{Indicação}

Os beta-bloqueantes estão indicados na terapêutica preventiva da EE sendo fármacos de primeira linha (propranolol e metoprolol) (grau de recomendação I), desde que não haja contraindicação ou intolerância.

Estão especialmente indicados em doentes com hipertensão arterial concomitante ou tremor essencial.

\section{Fármacocinética, dosagem e modo de administração}

O propranolol é um bloqueante não seletivo, altamente solúvel nos lípidos que penetra facilmente a barreira hematoencefálica. É de metabolização hepática. Liga-se de forma significativa às proteínas plasmáticas o que deverá ser tido em conta se usado em simultâneo com outros fármacos com ligação às proteínas como o valproato de sódio ou a amitriptilina. Tem semivida de 4-5 horas pelo que a administração deve ser bidiária o que pode limitar a adesão. ${ }^{19}$ Pela sua variabilidade farmacocinética deve ser feita titulação lenta para evitar efeitos secundários. ${ }^{32}$

As doses recomendadas variam entre 40 a $160 \mathrm{mg} /$ dia, pode ser eficaz com doses inferiores e as doses mais elevadas são mais eficazes. ${ }^{33}$

O metoprolol, é muito solúvel nos lípidos com boa penetração no SNC; é seletivo, inibindo apenas os recetores beta I, tem também eliminação hepática mas, ao contrário do propranolol, tem fraca ligação às proteínas plasmáticas. ${ }^{19}$ A sua semivida é de 3-7 horas e também tem uma variabilidade farmacocinética muito elevada requerendo titulação lenta para evitar concentrações plasmáticas elevadas que podem ser perigosas. ${ }^{32} \mathrm{~A}$ sua eficácia é dose dependente. ${ }^{34} \mathrm{~A}$ dose recomendada para o metoprolol é de 50 a $200 \mathrm{mg}$, para o timolol 20-30 $\mathrm{mg}$, nadolol 20-240 mg e para o atenolol 50 a $100 \mathrm{mg}$ (estes últimos com níveis de evidência $B$ ).

A combinação dos bloqueadores beta com fármacos com diferentes mecanismos de acção pode em teoria aumentar a resposta dos doentes refratários à monoterapia. ${ }^{35,36}$ Em dois ensaios abertos a adição de valproato de sódio ou de topiramato (sobretudo esta) aumentou a eficácia em comparação com monoterapia; no entanto um estudo duplamente cego controlado com placebo não evidenciou beneficio adicional com a combinação com topiramato, ${ }^{37}$ pelo que não há evidência que suporte a associação (grau de recomendação II, nível de evidência $B$ ).

\section{Contraindicações e precauções}

Como grupo eles estão contraindicados em doentes que sofram de asma brônquica, doença pulmonar crónica obstrutiva (por interferirem com a broncodilatação em dose dependente; este efeito é menor nos beta 1 seletivos como o metoprolol ${ }^{38}$ ), doença de Raynaud, bloqueio cardíaco, insuficiência cardíaca congestiva ${ }^{39}$, doença arterial periférica e relativamente contraindicados acima dos 64 anos (pelo efeito cronotrópico negativo), na diabetes mellitus e na insuficiência renal.

\section{Efeitos adversos}

Os efeitos secundários deste grupo correlacionam-se com o grau de seletividade para os recetores alfa ou beta, mas também depende da atividade intrínseca simpaticomimética, solubilidade lipídica e propriedades vasodilatadoras.

Mais frequentes são a fadiga, letargia, intolerância ao esforço, hipotensão arterial, tonturas, bradicardia sinusal, náuseas, broncospasmo, alterações do sono com pesadelos, sonhos vividos e insónia. Provocam ainda atraso na condução levando a bloqueio auriculoventricular sobretudo se utilizado em conjunto com fármacos com ação semelhante. Os beta-bloqueantes não seletivos causam redução do débito cardíaco, bloqueiam a vasodilatação nos músculos e consequentemente podem aumentar a insuficiência vascular na doença arterial periférica. ${ }^{40}$

Apesar de habitualmente ser referida a depressão 
como possível efeito secundário, uma extensa revisão de 45 anos de estudos não confirmou esta hipótese. ${ }^{41}$ De igual modo os efeitos sobre a função sexual (nomeadamente disfunção eréctil) parecem ser mínimos.

\section{Tolerabilidade e adesão terapêutica}

Os beta-bloqueantes são habitualmente bem tolerados; no entanto a taxa de descontinuação do tratamento com propranolol nos diversos ensaios clínicos variou entre $20 \%$ e $23 \%$, ${ }^{42}$ em cerca de $8 \%$ por efeitos secundários. Fora do contexto dos ensaios, a percentagem que mantem a terapêutica ao fim de 6 meses é de $25 \%$ e ao fim de 12 meses é de apenas 14\% ${ }^{43}$; as razões principais para o abandono do tratamento são baixa eficácia $(42,8 \%)$ e efeitos secundários $(35,9 \%) .{ }^{44}$

\section{Antagonistas dos canais de cálcio}

\section{Flunarizina (nível de evidência A)}

Neste grupo farmacológico apenas a flunarizina evidencia eficácia (nível A). É também considerada uma terapêutica de primeira linha na profilaxia da enxaqueca pelas sociedades científicas europeias. ${ }^{10}$

É desconhecido o seu mecanismo de ação na enxaqueca.

\section{Evidência}

Numa recente metanálise ${ }^{45}$ a flunarizina foi superior ao placebo em reduzir a frequência das crises às 8,12 , 20 e 24 semanas de terapêutica (DM 20,44; 95\% IC 20,6I a 20,26) na análise conjunta de 5 estudos com um total de 249 participantes: redução de 0,4 crises por mês em doentes com uma média de 4 crise por mês. $A$ taxa de respondedores (redução superiores a 50\%) foi significativamente maior que com o placebo (OR 8,86; $95 \%$ IC 3,57-22,0). No entanto é de ressalvar que os estudos existentes apresentam alguns problemas metodológicos e alto risco de enviesamento na maioria deles.

Não parece haver diferenças de eficácia entre a dosagem de 5 ou $10 \mathrm{mg}$ de acordo com um estudo com mais de 500 participantes. ${ }^{46}$ De igual modo não foram evidenciadas diferenças na eficácia clínica entre a flunarizina 10 mg/dia e o propranolol 60-160 mg em 7 estudos com um total de II 5 I participantes ${ }^{45,46}$ ou o topiramato num pequeno estudo com 83 participantes. ${ }^{47}$

\section{Indicação}

A flunarizina é também um fármaco de primeira linha na prevenção da EE (grau de recomendação I), desde que não haja contraindicação ou intolerância. Poderá ser particularmente útil (pelo perfil de efeitos secundários) nos doentes com insónia e com peso inferior ao desejável.

Farmacocinética, dosagem e modo de administração

Tem semivida terminal longa, de 15 dias e demora quase 2 meses a atingir concentração estável e a revelar a sua eficácia. ${ }^{48}$

A dosagem habitual é de $10 \mathrm{mg}$ por dia, mas deverá ser reduzida para $5 \mathrm{mg}$ em doentes que não a tolerem por sonolência ou nos doentes com idade superior a 65 anos. A toma deve ser realizada ao deitar pela sonolência associada. Não deve ser utilizada consecutivamente mais de 6 meses. ${ }^{49}$

\section{Efeitos adversos ${ }^{49}$}

Para além da sonolência outros efeitos secundários frequentes são o aumento de apetite e consequente aumento de peso (em especial nos tratamentos mais prolongados) e cansaço. Menos frequente humor depressivo, especialmente em mulheres que já sofreram anteriormente de depressão. Podem ainda surgir nos tratamentos prolongados, sintomas extrapiramidais como tremor, rigidez, bradicinesia e síndrome das pernas inquietas.

Outras reações adversas pouco frequentes, incluem: náuseas, epigastralgias, xerostomia, hiperplasia gengival, insónias, tonturas, cefaleias e irritabilidade.

\section{Contraindicações e precauções}

A flunarizina está contraindicada em doentes com depressão, doença de Parkinson, obstipação e hipotensão arterial. Está também contraindicada na gravidez. Deve ser utilizado com precaução em doentes com insuficiência hepática, glaucoma ou prostatismo e deve ser evitada nos doentes obesos.

\section{Outros antagonistas dos canais de cálcio}

Estudos de pequena dimensão avaliando a possível eficácia do verapamilo foram positivos (nível de evidência $\mathrm{C}$ ) e estudos com nimodipina, nicardipina, e diltiazem não revelaram superioridade sobre o placebo não se podendo recomendar a sua utilização nesta indicação. ${ }^{16}$

\section{Antiepiléticos}

Estes fármacos, também apelidados de neuromodulares por reduzirem a hiperexcitablidade cortical associada à enxaqueca são também fármacos de primeira 
linha na EE, com boa evidência. Os antiepiléticos com eficácia demonstrada nesta patologia são o valproato de sódio e o topiramato.

\section{Ácido valpróico e valproato de sódio (nível de evidência A)}

O ácido valpróico (sintetizado pela primeira vez em 1882, como análogo do ácido valérico encontrado na valeriana), o valproato de sódio ou a combinação dos dois (divalproato ou valproato semisódico) têm evidência de eficácia na EE. ${ }^{50}$

\section{Mecanismo de acção}

Possíveis mecanismos são o aumento da atividade neuroinibitória do GABA, a inibição dos sinais neuroexcitatórios do NMDA e em altas doses o aumento da concentração extracelular da serotonina, da dopamina e dos seus metabolitos ativos. ${ }^{51} \mathrm{O}$ ácido valpróico também bloqueia os canais de sódio dependentes da voltagem e os canais de cálcio tipo $\mathrm{T}$ e tem acção inibitória sobre a onda de depressão alastrante.

\section{Evidência}

Uma metanálise de 10 ensaios ${ }^{51}$ (6 randomizados controlados com placebo, 4 contra comparadores ativos) confirmou a eficácia do valproato de sódio na prevenção da EE em grupos paralelos ou cruzados, com doses variando entre 400 a 1500 mg/dia (nível de evidência A). As taxas de respondedores foram de $42 \%$ (30\% a $66 \%$ ) nos grupos ativos contra $21 \%$ (14\% a 24\%) no grupo placebo. Embora sem dados sobre o número de cefaleias por mês os resultados foram consistentes: a probabilidade de redução de $50 \%$ da frequência das cefaleias por mês é duas vezes superior com o valproato comparado com placebo. Cerca de 12\% dos doentes abandonaram o tratamento pelos efeitos secundários.

Dois estudos comparando valproato com flunarizina e com propranolol demostraram eficácia semelhante na proporção de respondedores. Dois pequenos estudos comparando valproato com topiramato evidenciaram ligeira, mas significativa vantagem do topiramato (menos um dia por mês $\left.{ }^{52,53}\right)$.

Não há evidência de eficácia sobre outros sintomas como aura ou pródromos.

\section{Indicação}

O valproato de sódio está indicado na profilaxia da EE como fármaco de primeira linha (grau de recomen- dação I), desde que não haja contraindicação ou intolerância, estando excluídas desta indicação as mulheres em idade fértil.

\section{Farmacocinética, dosagem e modo de administração}

O valproato é rapidamente absorvido atingindo o pico de concentração plasmática entre as I e 4 horas. A sua semivida é longa, cerca de 8 a 20 horas e atinge-se a concentração de equilíbrio aos 3-5 dias; liga-se em $90 \%$ às proteínas plasmáticas, ${ }^{50}$ a insuficiência renal prolonga a sua semivida e é excretado pela urina em vários metabolitos.

Deve ser administrado na enxaqueca com dosagem baixa de início (250 mg) com aumento lento e progressivo conforme tolerabilidade até doses que variam entre os 250 mg e os 1500 mg, administrados duas vezes ao dia. Obriga a monitorização hepática, do ionograma, hemograma e amilasémia que deverá ser realizada 2 vezes ao ano.

\section{Efeitos adversos}

Os efeitos adversos mais comuns são: náuseas, vómitos e desconforto gastrointestinal, sonolência, tonturas e desequilíbrio, defeito de memória, aumento de peso e sinais extrapiramidais. Raramente podem ocorrer hepatite e pancreatite, que são reações idiossincráticas imprevisíveis. ${ }^{54} \mathrm{Em} 40 \%$, podem haver alterações assintomáticas da função hepática. Podem surgir também trombocitopenia e outras discrasias sanguíneas requerendo vigilância analítica. Hiperandrogenismo, quistos do ovário e obesidade podem ocorrer em mulheres jovens.

Tem conhecidos efeitos teratogénicos nomeadamente defeitos do tubo neural ( I\%-2\% risco espinha bífida) e risco de malformações major; está também associado a baixo Ql em crianças cujas mães tomaram a droga durante a gravidez.

\section{Contraindicações e precauções}

Contraindicações absolutas são a gravidez e antecedentes de pancreatite ou doença hepática; outras são trombocitopenia, pancitopenia e discrasias hemorrágicas. Pelo risco teratogénico é fortemente desaconselhada a sua utilização em mulheres em idade fértil que devem sempre ser avisadas do risco.

Topiramato (nível de evidência A)

O topiramato é um monossacarídeo derivado da $D$-frutose $^{55}$ e um antiepilético, com evidência de eficácia, sendo um fármaco de primeira linha no tratamento da EE. 


\section{Mecanismo de acção}

O topiramato tem vários mecanismos de acção possíveis: bloqueio dos canais de sódio dependentes de voltagem (reduzindo a frequência das ondas de despolarização e modulando a excitabilidade cortical), inibição da atividade excitatória do glutamato, inibição dos neurónios do complexo trigeminocervical via acção do GABA e inibição da libertação de CGRP (péptido relacionado com o gene da calcitonina) nos neurónios pré-sinápticos do trigémeo. Tem também acção inibitória sobre os canais de cálcio de alta voltagem e de uma forma crónica inibe a onda de depressão alastrante. Diminui, pois, a transmissão excitatória e aumenta a neurotransmissão inibitória.

\section{Evidência}

Embora com alguma limitação metodológica, existe evidência robusta da eficácia do topiramato na EE: 17 estudos publicados, duplamente cegos e randomizados, 10 deles contra placebo $(n=1727)$ e os restantes 7 contra moléculas ativas. A duração do tratamento variou entre as 4 e as 52 semanas, em média 19 semanas. ${ }^{30,56,57}$ Os estudos com placebo evidenciaram que o topiramato é mais eficaz na redução dos dias de cefaleias do que o placebo e em todas as doses estudadas $(50,100$ ou 200 $\mathrm{mg}$ ) e em todos os prazos avaliados, ${ }^{58}$ com redução de mais I,2 dias que o placebo, em doentes em média com 5,6 dias de enxaqueca na baseline. A análise combinada de 9 estudos contra placebo $(n=1190)$ evidenciou que os pacientes medicados com topiramato têm o dobro da probabilidade de responderem ao tratamento: $47 \%$ de respondedores no grupo ativo e $23 \%$ no grupo placebo.

Em apenas 2 estudos foram avaliadas medidas de qualidade de vida com resultados positivos.

Nos 3 estudos que avaliaram diferentes doses de topiramato $^{30,56,57}$, as doses de $200 \mathrm{mg}$ e de $100 \mathrm{mg}$ foram significativamente superiores à de $50 \mathrm{mg}$ na redução da frequência das cefaleias (DM -0,96; 95\% IC - I,53 a $-0,40 ; 463$ participantes e DM -0,7I; 95\% IC -I,32 a $-0,10,479$ participantes) e no aumento da percentagem de respondedores (OR I,66; 95\% IC I, I5 a 2,4I; 462 participantes e OR I,80; 95\%, IC I, 25 a 2,60, 478 participantes). No entanto a dose de $200 \mathrm{mg}$ não foi superior à de $100 \mathrm{mg}$. De realçar que nenhum destes estudos foi desenhado de modo a ter poder estatístico suficiente para permitir comparar as diferentes doses. Sete estudos avaliaram a eficácia do topiramato em relação a outros comparadores: amitriptilina ${ }^{59}$ (um estudo, 330 participantes); flunarizina ${ }^{47}$ (um estudo, 83 participantes); propranolol ${ }^{29,30}$ (dois estudos, 342 participantes); valproato de sódio ${ }^{52,53}$ (dois estudos, 120 participantes) e técnicas de relaxamento (um estudo, $6 \mathrm{I}$ participantes); em todos, os comparadores foram igualmente eficazes exepto num pequeno estudo com valproato $(n=36)$ em que houve ligeira vantagem do topiramato. Todos os estudos em que foram utilizados 100 ou 200 $\mathrm{mg}$ de topiramato demonstraram, sem ambiguidades, a superioridade do topiramato na redução do número de cefaleias por mês e na proporção de respondedores.

De igual modo, num ensaio comparando topiramato isolado com betabloqueante associado não houve ganho de eficácia com a associação do betabloqueante. ${ }^{37}$

Não há evidência que permita afirmar se é ou não eficaz noutros sintomas da enxaqueca por exemplo nos pródromos ou auras.

\section{Indicação}

O topiramato está indicado para tratamento preventivo da EE, como fármaco de primeira linha (grau de recomendação I), desde que não haja contraindicações ou intolerância, devendo apenas ser prescrito nas mulheres em idade fértil se fizerem contraceção eficaz.

\section{Farmacocinética, dosagem e modo de administração}

A bioavaliabilidade oral é de $81 \%$ a $95 \%$. O volume de distribuição nas mulheres é aproximadamente $50 \%$ do dos homens. É apenas metabolizado em $20 \%$ e a sua excreção é predominantemente renal. Tem uma longa semivida ( 19 to 25 horas).

A dose habitual na EE varia entre 50 a $200 \mathrm{mg}$, mas por vezes pode ser eficaz logo aos $25 \mathrm{mg}^{58}$

Inicia-se o tratamento utilizando doses de 15 a $25 \mathrm{mg}$ ao deitar que se vão incrementando semanalmente (I5$25 \mathrm{mg}$ de cada vez) até à dose de $50 \mathrm{a} 100 \mathrm{mg}$ por dia, se necessário até aos $200 \mathrm{mg}$. A titulação é interrompida se surgirem efeitos adversos significativos; nestes casos a dose deve ser reduzida até à última tolerada e depois aumentada mais lentamente. Deve ser administrado duas vezes ao dia.

\section{Efeitos adversos}

O topiramato tem efeitos secundários neurocognitivos dependentes da dose que incluem: diminuição de atenção e da capacidade de concentração, dificuldade de evocação de nomes, lentificação do pensamento e 
dos processos mentais, defeito de memória, alteração do humor (depressão, irritabilidade) e fadiga mental, efeitos que limitam o seu benefício.

Devido ao seu efeito inibidor da anidrase carbónica ${ }^{16}$ causa parestesias (o efeito secundário mais frequente, em $53 \%$, e que pode melhorar com suplementação de potássio), alterações do paladar, aumento do risco de litíase renal (a incidência é I,5\% ou seja 2 a 4 vezes mais frequente que na população geral), acidose metabólica e hipocaliemia. À semelhança de outras sulfonamidas aumenta o risco de efeitos adversos oftálmicos graves incluindo miopia por glaucoma agudo de angulo fechado e alterações visuais sem aumento da pressão intraocular. Outros efeitos incluem anorexia, cansaço, tonturas, náuseas, dores abdominais, diarreia e perda de peso que é dependente da dose (redução entre $2,3 \%$ a $3,8 \%$ do peso corporal).

O topiramato é teratogénico estando associado a um aumento de taxa de malformações fetais (nomeadamente lábio leporino e fenda palatina) $)^{16}$ pelo que não deve ser usado em mulheres em idade fértil a não ser que utilizem contraceção eficaz.

O topiramato aumenta a excreção de etinilestradiol pelo que pode reduzir a eficácia dos anticoncetivos orais de baixa dosagem quando administrado em doses superiores a $200 \mathrm{mg}$ por dia. ${ }^{60}$

\section{Tolerabilidade e adesão terapêutica}

A taxa de abandono nos ensaios clínicos foi de $43,1 \%$ em que $23,7 \%$ se deveu a efeitos secundários. ${ }^{42}$ Nos dados de vida real apenas $25 \%$ mantem a toma ao fim de 6 meses e apenas I $4 \%$ ao fim de I ano ${ }^{44}$ : $40 \%$ abandonam por falta de eficácia e $46 \%$ por efeitos secundários. ${ }^{45}$

\section{Outros antiepiléticos}

Os estudos com gabapentina e pregabalina não demonstraram superioridade em relação ao placebo. ${ }^{61}$ Para outros antiepilépticos ${ }^{62}$ (levetiracetam, lamotrigina, oxcarbamazepina, clonazepam, vigabantrina e zonisamida) não há evidência ou ela é insuficiente para apoiar a sua utilização na prática clínica.

\section{Antidepressivos}

Antidepressivos tricíclicos (nível de evidência A)

Os antidepressivos tricíclicos foram os mais estudados na enxaqueca (amitriptilina, clomipramina e doxepina) e são fármacos de primeira linha na EE.

\section{Mecanismo de acção}

Desconhecem-se os mecanismos de ação dos antidepressivos sobre a EE, mas não se devem à acção sobre uma depressão incipiente ou não diagnosticada. A resposta ocorre mais precocemente e com doses menores que para tratamento da depressão. Possíveis mecanismos de acção sobre a enxaqueca poderão ser a inibição da recaptação de norepinefrina e/ou serotonina, o efeito antagonista sobre os receptores 5-HT2 (5-hidroxitriptamina), a modulação da transmissão dopaminérgica e o incremento da acção do sistema modulador endógeno da dor. ${ }^{63}$

\section{Evidência}

A amitriptilina foi o antidepressivo avaliado em maior número de ensaios ${ }^{64}(7)$, embora dois deles apenas tiveram 4 semanas de duração. $\bigcirc$ número de doentes avaliados foi de 1570, em média durante 10 semanas. A amitriptilina tem maior probabilidade que o placebo em reduzir $50 \%$ ou mais as cefaleias (nível de evidência A). Também a clomipramina e a doxepina foram mais eficazes que o placebo. Em estudos comparativos a amitriptilina foi tão eficaz como os SSRI, o topiramato e o propranolol.

\section{Indicação}

A amitriptilina é tratamento de primeira linha na $E E$ (grau de recomendação I) na ausência de contraindicação ou intolerância.

Estes fármacos são especialmente úteis nos doentes que apresentem insónia ou depressão ou cujas crises estão relacionadas com ansiedade e stress.

\section{Farmacocinética, dosagem e modo de administração}

Dos tricíclicos a amitriptilina é o mais utilizado; as doses variam muito devendo ser individualizadas, e necessariamente maiores para doente com depressão clínica. A amitriptilina é uma amina terciária e tem efeito sedativo, pelo que, se deve iniciar com doses baixas, aumento progressivo e tomada ao deitar, cerca de 8 a 10 horas antes de acordar. Deve-se começar o tratamento com 10 a 25 mg; a dose eficaz varia entre 25 a $150 \mathrm{mg}$.

A noritriptilina, metabolito major da amitriptilina é uma amina secundária, menos sedativa que a amitriptilina; a dose inicial é de 10 a 25 mg ao deitar e a dose usual varia entre os 10 e os $150 \mathrm{mg} .{ }^{60}$ 


\section{Efeitos secundários}

Os efeitos secundários anticolinérgicos são frequentes: boca seca, desconforto epigástrico, obstipação, tonturas, confusão mental, taquicardia, palpitações, visão turva e retenção urinária. Outros efeitos secundários relativamente frequentes são: aumento de peso, hipotensão ortostática, prolongamento do intervalo QT, redução do limiar epileptógeno e sedação. Podem levar à conversão da depressão para hipomania ou mania franca sobretudo nos doentes com doença bipolar. Podem agravar o glaucoma. Os idosos correm o risco de quadro confusional agudo. Os efeitos antimuscarínicos e antiadrenérgicos aumentam o risco de alterações da condução cardíaca especialmente nos doentes idosos, obrigando neste grupo etário a monitorização cuidada ou a considerar outros fármacos.

\section{Contraindicações e precauções}

Glaucoma, mania, retenção urinária, bloqueio cardíaco, taquiarritmias, hipersensibilidade, hipoglicémia (diabetes sob tratamento).

\section{Tolerabilidade}

À semelhança dos outros preventivos orais, a amitriptilina sofreu uma taxa de abandono durante os ensaios clínicos de 45, I\%, em cerca de 16,7\% por efeitos adversos. ${ }^{42}$ De igual modo fora do âmbito dos ensaios clínicos apenas $25 \%$ mantem terapêutica ao final de 6 meses e I $4 \%$ ao final de I ano. ${ }^{43}$

\section{Outros antidepressivos}

Foram testados SSRI (inibidores seletivos da recaptação da serotonina) mas os resultados são escassos e contraditórios. A sertralina não foi eficaz num único ensaio realizado e a fluoxetina, avaliada em 4 ensaios, apresentou resultados contraditórios nos diferentes estudos.

Dos inibidores da recaptação da serotonina e noradrenalina (SNRI) a venlafaxina demonstrou eficácia num ensaio duplamente cego controlado com placebo ${ }^{65}$ (evidência nível B) e também num ensaio comparando com placebo e amitriptilina. ${ }^{66}$ Nos doentes que não toleram os antidepressivos tricíclicos a utilização de um SNRI poderá ser uma alternativa (grau de recomendação llb, nível de evidência B). A dose usual da venlafaxina é 150 $\mathrm{mg} / \mathrm{dia}$. Comparado com os antidepressivos tricíclicos os SNRI têm menos efeitos anticolinérgicos e bloqueadores alfa com redução do risco de hipotensão ortostá- tica e de queda. Os efeitos secundários mais frequentes são insónia, irritabilidade, midríase e convulsões.

\section{Outros preventivos orais}

Serotoninérgicos e antagonistas serotoninérgicos

Apesar do pizotifeno e a ciproheptadina serem fármacos anteriormente muito utilizados na enxaqueca, não se encontram disponíveis no nosso país pelo que não serão abordados. $\mathrm{O} 5$-hidroxitriptofano ou oxitriptano, intermediário metabólico na síntese da serotonina e melatonina, não possui evidência de eficácia na enxaqueca pelo que a sua utilização não é recomendada. ${ }^{67,68}$

Inbidores da enzima conversora da angiotensina e bloqueadores dos receptores da angiotensina II

O lisinopril, o enalapril, e o captopril foram avaliados em apenas um único estudo cada; apesar de resultados positivos para o lisinopril e captopril a evidência não é suficiente para uma recomendação de utilização. ${ }^{69} \mathrm{O}$ mesmo sucede com o candesartan estudado em 2 pequenos ensaios com resultados positivos na dose de 16 $\mathrm{mg}$, um deles duplamente cego contra placebo e outro comparando com propranolol (160 mg) com eficácia semelhante..$^{70,71}$

\section{Melatonina}

A melatonina foi avaliada em 5 ensaios clínicos, ${ }^{72}$ três duplamente cegos contra placebo e I comparando com amitriptilina e outro com valproato de sódio. Nos estudos comparativos a melatonina foi tão eficaz como os comparadores. Nos estudos controlados com placebo, com metodologias muito diversas, os resultados foram contraditórios (2 negativos e I positivo) pelo que não está comprovada a sua eficácia. A administração crónica de melatonina poderá provocar toxicidade hepática, disfunção reprodutiva e exacerbação da autoimunidade.

\section{Nutracêuticos}

A riboflavina, a coenzima Q10, o magnésio e a matricária (Tanacetum parthenium) poderão ser considerados na profilaxia da enxaqueca. Em relação ao co-enzima Q10 os estudos realizados são de muito pequenas dimensões e com resultados contraditórios. Num estudo observacional em que se utilizou Tanacetum parthenium, magnésio e coenzima Q10 esta associação parece ser eficaz na redução dos dias com enxaqueca ${ }^{73}$ (evidência nível C). A EHF ${ }^{10}$ sugere a utilização destes nutracêuti- 
cos, apesar da reduzida evidência, desde que disponibilizados em preparados com qualidade farmacêutica. Podem ser opção em doentes com efeitos adversos intoleráveis ou contraindicação aos fármacos preventivos.

\section{B. Fármaco preventivos injetáveis}

\section{Bloqueios anestésicos de nervo grande occipital} (nível de evidência B)

O bloqueio anestésico do nervo grande occipital (com ou sem adição de corticoide local) tem sido utilizado no tratamento da enxaqueca quer como abortivo (em crises prolongadas) quer como preventivo. A razão de tal abordagem advém de o nervo grande occipital ser aferente das raízes sensitivas ao nível de C2 que formam parte do complexo trigeminocervical: a informação sensitiva vinda do nervo anestesiado poderá modificar a integração da informação nociceptiva das áreas inervadas pelo trigémeo e levar à redução da sensibilização de C2. Numa metanálise ${ }^{74}$ de 7 ensaios clínicos randomizados e controlados com placebo (injeção de soro), com a utilização do bloqueio anestésico (com bupivacaina ou lidocaina) do grande nervo occipital, em casos de enxaqueca episódica e crónica, num total de 323 doentes, houve uma diminuição da intensidade da cefaleia (DM=-0,89; 95\% IC =-I,38 a -0,39; $p=0,0005)$ ) e do consumo de analgésicos (DM=-I I $10 ; 95 \% \mathrm{Cl}=-2,07$ a $-0,14 ; p=0,02)$ mas não da duração da cefaleia (DM=6,96; 95\% Cl=-|4,09 a 0,18 p=0,006). A metodologia, dose, anestésicos, local e número de injeções foi variável; a adição de corticóides não parece aumentar o efeito terapêutico. ${ }^{73}$ Complicações descritas são infeção, hematoma e lesão das estruturas locais. Efeitos secundários sistémicos também são possíveis embora extramente raros se técnica correta. É minimamente invasivo e habitualmente bem tolerado (em 600 procedimentos apenas reportados 39 eventos adversos ${ }^{75}$ ). Poderá ser uma alternativa em doentes selecionados (grau I, nível B). Não deve ser utilizado em doentes com soluções de continuidade craniana, infeções locais e alergia a anestésicos locais.

\section{Anticorpos monoclonais dirigidos ao CGRP ou ao seu recetor (Amc-CGRP e Amc-rCGRP) (nível de evidência A)}

Para a profilaxia da enxaqueca foram recentemente desenvolvidos anticorpos monoclonais dirigidos a um alvo que se sabe ser fundamental na fisiopatologia da crise de enxaqueca: o CGRP, calcitonin gene related peptide (péptido relacionado com o gene da calcitonina). $O$ CGRP é um pequeno neuropéptido de 37 aminoácidos que resulta do processamento alternativo no sistema nervoso do gene da calcitonina ${ }^{76}$. Ele está amplamente distribuído no SNC e SNP, é um potente vasodilatador, está implicado na transmissão nociceptiva e é um neuropeptido próinflamatório. O CGRP é produzido e libertado pelos neurónios sensitivos das fibras C, não mielinizadas e atua nos neurónios das fibras sensitivas Ad, pouco mielinizadas. É o neurotransmissor mais abundante no gânglio do trigémeo e intervem na ativação do sistema trigeminovascular. Descoberto em 1982 por Susan Amara e colaboradores ${ }^{77}$, é conhecido o seu papel na enxaqueca já há décadas, sendo considerado um marcador da atividade trigeminovascular ${ }^{78}$. É libertado durante a crise de enxaqueca aumentando os seus níveis na veia jugular; os triptanos, eficazes no tratamento agudo da crise, revertem esse aumento do CGRP e a administração endovenosa do CGRP desencadeia uma cefaleia com as características de enxaqueca, em pessoas suscetíveis ${ }^{79}$.

Foram desenvolvidos vários fármacos contra o CGRP; os primeiros, pequenas moléculas denominadas gepants, antagonistas do recetor do CGRP, são eficazes no tratamento sintomático da enxaqueca e, mais recentemente, estão também a ser avaliados para o tratamento preventivo (nesse caso o atogepant e o rimegepant), já com alguns resultados positivos ${ }^{80}$.

Em 2007 desenvolveram-se os primeiros anticorpos monoclonais contra o CGRP ou contra o seu recetor, grandes glicoproteínas de administração parentérica e longa semivida e os primeiros ensaios clínicos com estas moléculas ocorreram a partir de 2013. Pela primeira vez foram desenvolvidos fármacos preventivos específicos para a enxaqueca.

Quatro anticorpos monoclonais foram produzidos para tratamento preventivo da enxaqueca: um anticorpo humano anti-rCGRP (erenumab) e os restantes três anticorpos humanizados anti-ligando, anti-CGRP (fremanezumab, galcanezumab e eptinezumab). Todos são de administração subcutânea exepto o eptinizumab que é de administração endovenosa. Todos eles têm evidência da sua eficácia no tratamento preventivo da enxaqueca (nível de evidência $A$ ) e estão aprovados pela FDA e pelas autoridades europeias (com exceção do eptinezumab nesta última), encontrando-se já comercializa- 
dos em muitos países europeus. Não são fármacos de primeira linha; são considerados de segunda ou terceira linha segundo as autoridades regulatórias de cada país. O erenumab e o fremanezumab já estão disponíveis em Portugal, e espera-se que brevemente o galcanezumab também esteja. À data da redação destas recomendações o erenumab, o fremanezumab e o galcanezumab, já têm aprovada a comparticipação pelo Estado.

Na Tabela 3.3.4 encontram-se as doses, forma e frequência de administração dos 4 anticorpos monoclonais. ${ }^{81}$

Tabela 3.3.4. Anticorpos monoclonais prevenção enxaqueca ${ }^{81}$

\begin{tabular}{|c|c|c|c|c|}
\hline Nome & Eptinezumab & Erenumab & Fremanezumab & Galcanezumab \\
\hline Tipo & IgG1 humanizada & $\operatorname{lgG} 2$ humana & IgG2 humanizada & IgG4 humanizada \\
\hline Alvo terapêutico & CGRP & $\begin{array}{l}\text { Recetor CLR/ } \\
\text { RAMP1 }\end{array}$ & CGRP & CGRP \\
\hline Linhagem produção celular & levedura & $\begin{array}{l}\text { ovário hamster } \\
\text { chinês }\end{array}$ & $\begin{array}{l}\text { ovário hamster } \\
\text { chinês }\end{array}$ & $\begin{array}{l}\text { ovário hamster } \\
\text { chinês }\end{array}$ \\
\hline Via de administração & iv (infusão 1 hora) & sc & sc & sc \\
\hline Frequência administração & $3 / 3$ meses & mensal & $\begin{array}{l}3 / 3 \text { meses ou } \\
\text { mensal }\end{array}$ & mensal \\
\hline Tmax & $2,5-2,8$ horas & 4-11 dias & 5-11 dias & 7-14 dias \\
\hline$t 1 / 2$ & 23-33 dias & $\sim 21$ dias & 31-39 dias & 25-32 dias \\
\hline Dosagem & 100 ou 300 mg & 70 ou 140 mg/mês & $\begin{array}{l}225 \mathrm{mg} / \mathrm{mês} \text { ou } \\
675 \text { a cada } 3 \text { meses }\end{array}$ & $\begin{array}{l}\text { Dose carga } 240 \mathrm{mg} \\
\text { seguida de } 120 / \mathrm{mês}\end{array}$ \\
\hline
\end{tabular}

Como vantagens destes medicamentos para além da sua eficácia, é a menor incidência de efeitos secundários, quando comparada com os preventivos orais, e o início de ação mais rápido. Estas propriedades facilitam a adesão dos doentes à terapêutica ${ }^{82,83}$.

\section{Mecanismo de acção}

O CGRP e o seu recetor encontram-se amplamente distribuídos no SNC e SNP.

O erenumab é uma imunoglobulina lgG2 humana que se liga ao recetor canónico do CGRP bloqueando-o de forma reversível. Ele pode inibir até $99 \%$ da atividade do recetor consoante a concentração ${ }^{81}$.

Os outros anticorpos, fremanezumab (IgG2a humanizada), galcanezumab (IgG4 humanizada) e o eptinezumab (IgGI humanizada) são dirigidos contra o ligando CGRP podendo atuar sobre as suas duas isoformas ( $\alpha \mathrm{e}$ $\beta$ ). A isoforma $\alpha$ existe essencialmente no sistema nervoso enquanto a $\beta$ se encontra no intestino. Eles ligam-se avidamente e especificamente ao CGRP impedindo a sua atividade nomeadamente a interação com o respetivo recetor, mas sem o bloquear.

Os anticorpos monoclonais, moléculas proteicas de grandes dimensões, não atravessam a barreira hematoencefálica e acredita-se que exercem o seu efeito na enxaqueca por ação periférica ao nível do gânglio do trigémeo, local em que o CGRP e o seu recetor estão abundantemente representados ${ }^{76}$.

\section{Evidência}

Todos os novos anticorpos monoclonais têm evidên$\mathrm{cia}^{84,85}$ de qualidade e consistente, da sua eficácia no tratamento preventivo da enxaqueca obtida em diversos ensaios clínicos, com metodologia apropriada (multicêntricos, duplamente cegos e randomizados) de acordo com as orientações da $\mathrm{IHS}^{86}$ e com um elevado número de participantes (evidência de nível A).

Embora a metodologia utilizada nos diferentes ensaios no que se refere a seleção de doentes, objetivos primários e secundários e metodologia de avaliação de eficácia, tenha sido distinta, os resultados positivos obtidos são muito consistentes para os vários anticorpos. A sua eficácia clínica é muito semelhante como grupo e traduz-se na melhoria de vários parâmetros: redução dos dias de cefaleias e de enxaqueca por mês, percentagem de respondedores (redução $\geq 50 \%$, redução $\geq 75 \%$ e redução de $100 \%$ ), redução do consumo de abortivos, melhoria da incapacidade medida em escalas de impacto e melhoria da qualidade de vida.

Todos os subcutâneos foram testados em múltiplos 
ensaios de fase 2 e fase 3, na enxaqueca com e sem aura, na EE e EC e em doentes com falências prévias de outros preventivos ( 2 a 4 ) ou com abuso de analgésicos. O eptinezumab foi avaliado na EE e na EC com e sem abuso de analgésicos ${ }^{87,88}$.

Apresentamos os resultados dos ensaios pivotais que levaram à aprovação pelas entidades reguladoras.

O erenumab foi estudado na enxaqueca episódica (entre 4 a 14 dias de enxaqueca/mês) em 2 ensaios de fase 3. O estudo STRIVE ${ }^{89}$ teve a duração de 24 semanas, mais de 950 doentes incluídos em que $40 \%$ tinha falhado um ou mais preventivos prévios. Os doentes submetidos a erenumab tiveram uma redução mantida e sustentada dos dias de enxaqueca por mês $(-3,7$, $-4,0$ a $-3,3$, IC 95\%, $p<0,00$ I na dose de $140 \mathrm{mg}$, e $-3,2-3,6$ a $-2,9$, IC 95\%, $p<0,00$ I na dose de $70 \mathrm{mg}$ ) quando comparados com placebo (-I.8, -2.2; -I,5, IC 95\%). Também a \% de respondedores (redução de 50 ou mais percentagem na frequência das cefaleias) foi significativamente superior nos doentes tratados com erenumab (50\% e $43,3 \%$ nos 140 ou 70 mg) versus placebo $(26,6 \%)(p<0,00 \mathrm{I})$. Nas medidas de impacto a diferença em relação ao placebo foi também significativa. No ARISE ${ }^{90}$, com 577 participantes (oriundos dos EUA e Europa, e entre estes também de Portugal) foi estudada a dose de $70 \mathrm{mg}$ durante 12 semanas em dupla ocultação a que se seguiu fase aberta de 28 semanas; foram excluídos doentes com mais de 2 falhas prévias. Houve uma redução de 2,9 dias de enxaqueca por mês (versus I,8 dias no grupo placebo) ( $p<0,00 \mathrm{I})$ e uma resposta a $50 \%$ em $39,7 \%$ dos pacientes em comparação com $29,5 \%$ no grupo placebo $(p=0,001)$

Posteriormente foi realizada uma outra avaliação (estudo LIBERTY) ${ }^{83}$ com o erenumab na EE com falência prévia de 2 a 4 tratamentos preventivos, na dose de I 40 mg: houve $30,3 \%$ de respondedores no braço ativo contra $13,7 \%$ no braço placebo $(p=0,002)$.

Numa metanálise dos ensaios clínicos realizados com erenumab $^{91}$ em que foram analisados 5 ensaios clínicos, apenas um deles na EC, os restante 4 na EE, num total de 2928 adultos com idades compreendidas entre 18 e 65 anos, ambas as dosagens de erenumab (70 e $140 \mathrm{mg}$ ) foram eficazes em todos os parâmetros avaliados (redução dos dias de enxaqueca por mês, taxa de respondedores com redução de $50 \%$, redução dos dias consumo de medicação específica de enxaqueca e medidas de impacto e qualidade de vida) e em todas as datas de avaliação (4, 12 e 24 semanas) sendo que a eficácia se revelou logo no primeiro mês de tratamento. $\mathrm{Na}$ análise conjunta desses 5 ensaios a redução da média de dias de enxaqueca por mês para ambas as dose de erenumab em comparação com o placebo (foi de - I,32 dias (IC 95\% - I,73 a -0,9, p<0,0000I), o aumento da taxa de respondedores (acima de 50\%) foi de: $R R=1,55$, (IC $95 \% \mathrm{I}, 35$ a I,77, $p<0,0000 \mathrm{I}$ ) e a redução média de dias com toma de medicação específica para a enxaqueca contra placebo foi de DM - I,4 I, IC 95\% p<0,000 I .

A eficácia do fremanezumab foi avaliada em dois ensaios pivotais na enxaqueca episódica. Num estudo de fase 3 multicêntrico ${ }^{92}$, de 12 semanas, um total de 875 doentes foram aleatorizados para um de três braços: uma administração de 675 mg de fremanezumab seguida de administração mensal de placebo durante 2 meses ( $n=291$ ), $225 \mathrm{mg}$ de fremanezumab mensal $(n=290)$ ou administração mensal de placebo $(n=294)$. Na dose de $675 \mathrm{mg}$ a redução média dos dias de enxaqueca foi de $-3,4(-3,94$ a -2,6, IC 95\% p <0,00I), na dose de $225 \mathrm{mg}$ foi de $-3,7(-4,15$ a -3, I 8, IC 95\%, $p<0,00$ I) e no grupo placebo -2,2 (-2,68 a- I,7I). Também houve diferenças significativas na taxa de respondedores a $50 \%(44,4 \%$ na dose trimestral, $47,7 \%$ na dose mensal versus $27,9 \%$ no placebo, $p<0,001)$ ou a $70 \%$ : $(9,7 \%$ no placebo, $18,4 \%$ na dose de $675 \mathrm{mg}, p=0,0025$ e $18,5 \%$ na dose de $275 \mathrm{mg}$ mensal, $p=0,0023$ ) e na redução do dias de consumo de medicação aguda e da pontuação da escala de MIDAS.

fremanezunab foi também avaliado em doentes com falências prévias de medicação preventiva (2 a 4), no estudo Focus ${ }^{93}$ onde foram incluídos doentes com enxaqueca episódica $(n=329)$ e crónica $(n=509)$; ambos os regimes de fremanezumab ( $225 \mathrm{mg}$ mensal ou $675 \mathrm{mg}$ trimestral) evidenciaram eficácia significativa na redução do número de crises por mês às 4, 8 e 12 semanas de terapia. De referir que para o fremanezumab $2 \%$ dos doentes estudados apresentavam mais de 65 anos.

Uma metanálise ${ }^{94}$ de 5 ensaios clínicos realizados com fremanezumab envolvendo 3379 doentes ( 2 na EE e 3 na EC, um deles com 2 a 4 falências prévias), revelou a eficácia do fremanezumab em todos os tipo de enxaqueca e nas várias dosagens administradas (dose mensal de $225 \mathrm{mg}$ na EE, e $675 \mathrm{mg}$ seguidas de $225 \mathrm{mg}$ nos dois meses seguintes na EC ou dose trimestral de $675 \mathrm{mg}$ ) e também nos casos de falência prévia. Analisando o conjunto destes ensaios e seus resultados às 
12 semanas de seguimento houve uma redução de 2,36 dias com cefaleias comparando com placebo (IC 95\% $-3,17,-1,56, p<0,0001$ ) e 2,2 I dias com enxaqueca por mês (IC 95\%, -3,03, - I,38, $p<0,000 \mathrm{I}$ ). A percentagem de respondedores (acima de 50\%) foi significativamente superior em relação ao placebo $(R R=2,22$, IC 95\%, I,6 a 3,07, $p<0,000$ I).

galcanezumab foi estudado em 2 ensaios clínicos pivotais de fase 3 na EE: o EVOLVE $195(n=858)$ e o EVOLVE 296 ( $n=915)$ doentes). Houve uma redução de dias de enxaqueca por mês de $-4,18$ a 4,73 nas doses de $120 \mathrm{mg} / \mathrm{mensal}$ e $240 \mathrm{mg} / \mathrm{mensal}$ comparado com placebo que variou entre $-2,28$ a $-2,83$ (IC 95\%, $p<0,00$ I). Essa diferença significativa em relação ao placebo também se verificou nos outros parâmetros avaliados: redução de $50 \%$ (60,9 a $62,3 \%$ no Evolve I versus $38,6 \%$ no placebo, $p<0,00$ I e $59,3 \%$ a $56,5 \%$ vs $30 \%$ no placebo no Evolve 2 p<0,00I), 75\% ou 100\% na frequência das crises, na redução do consumo de medicamentos de fase aguda bem como melhoria significativa nas escalas de qualidade de vida e impacto funcional.

O galcanezumab foi também testado na EE e na EC refratária a 2 a 4 outros preventivos incluindo a toxina onabotulinica $A$, no estudo CONQUER ${ }^{97}$, em 462 doentes dos 18 aos 75 anos, com dose mensal de $120 \mathrm{mg}$ após dose de carga de $240 \mathrm{mg}$, em que o objetivo primário (redução de 4,I dias de enxaqueca por mês de I 3,4 dias no baseline no grupo tratado e menos I dia por mês no grupo placebo, $p<0,0001$ ) e todos os secundários foram atingidos.

Numa metanálise ${ }^{98}$ de 5 ensaios realizados com galcanezumab ( 2 de fase 2 e 2 de fase 3 na EE e I de fase 3 na EC) para um total de 3565 doentes na dose de $120 \mathrm{mg}$, houve uma redução de dias com enxaqueca por mês de $-I, 79$ (95\% IC , -2,06 a -I,53, $p<0000 I)$ e de $-\mathrm{I}, 85(-\mathrm{I}, 94 \mathrm{a}-\mathrm{I}, 76, p<0,0000 \mathrm{I})$ para a dose de $240 \mathrm{mg}$, comparando com o placebo.

O eptinezumab foi avaliado no estudo PROMISE- ${ }^{87}$ também na EE e com 6 meses de duração de tratamento nas doses de $30 \mathrm{mg}, 100 \mathrm{mg}$ ou $300 \mathrm{mg}$ administrados por via ev a cada 3 meses. Oitocentos oitenta oito doentes foram incluídos. A redução dos dias com enxaqueca por mês (diferença em relação ao efeito obtido com placebo) foi de $-0,82(p=0,0046)$ na dose de $30 \mathrm{mg}$, $0,69(p=0,018)$ na dose de $100 \mathrm{mg}$ e $-\mathrm{I}, \mathrm{II}(p=0,00 \mathrm{I})$ na dose de $300 \mathrm{mg}$. Este fármaco está aprovado para utilização nos EUA nas dosagens de 100 e 300 mg.
Uma metanálise recente ${ }^{99}$, avaliou todos os ensaios de fase 2 e fase 3 realizados na enxaqueca episódica: I 5 ensaios ( 5 com galcanezumab, doses entre 5 a 300 mg, 3 com fremanezumab entre 225 mensal ou 675 trimestral, eptinezumab 2 ensaios testando 30 a 1000 mg e erenumab 5 ensaios nas doses de 7, 21, 70 e $140 \mathrm{mg}$ ) num total de 8075 doentes. O objetivo primário dos vários estudos foi a redução dos dias de cefaleia moderada a severa/ enxaqueca por mês. Na totalidade obteve-se em relação ao placebo em média até - I,50 dias de enxaqueca por mês (IC 95\% - I,85 a -I, I6, p<0,000I), que embora pareça de pequena dimensão representou uma efetiva melhoria conforme percecionada pelos doentes.

Todos os Acm evidenciam redução significativa do número de cefaleias face ao placebo logo na primeira semana e por vezes (galcanezumab e eptinezumab) logo no primeiro dia. São também eficazes nos outros sintomas da enxaqueca e nas auras. Todos eles são eficazes na melhoria da qualidade de vida e na redução de incapacidade avaliada nas diferentes medidas centradas nos doentes (PRO - patient reported outcomes)

\section{Indicação e recomendações para a seleção}

Os Acm foram aprovados, nos países europeus, para tratamento de doentes com EE com mais de 4 dias de enxaqueca por mês. Entende a SPC, à semelhança das suas congéneres de outros países ${ }^{2,100}$ (AHS e EHF), que a prescrição deste tipo de medicamentos inovadores mas com custos significativamente maiores que os preventivos orais e dos quais ainda há pouco experiência na vida real, deve estar submetida a regras bem definidas que acautelem os interesses dos doentes e que permitam uma correta avaliação de eficácia e segurança na vida real e a longo prazo. Assim aconselha a SPC que a prescrição seja feita por peritos (neurologistas com diferenciação específica em cefaleias) e em centros/consultas de referência.

Estes tratamentos não são de primeira linha estando indicados para o tratamento preventivo da EE nas situações de falência (após administração em dose e tempo adequado) ou na presença de efeitos adversos, intolerância ou contraindicação aos outros preventivos orais disponíveis (grau de recomendação I). Define-se como falência terapêutica a ausência de redução significativa ( $\geq 50 \%$ ) da frequência das cefaleias após 2-3 meses de terapêutica, ${ }^{10}$ segundo a EHF. 
A SPC recomenda que os anticorpos monoclonais anti-CGRP ou anti -rCGRP sejam utilizados na terapêutica preventiva de doentes com EE, com e sem aura, que tenham mais de 8 crises por mês ou entre 4 a 8 crises por mês se associadas a incapacidade (avaliada por medidas simples de impacto), e não tenham tido resposta em dose e tempo adequado (no mínimo 8 semanas e idealmente 12 semanas) e/ou tenham efeitos adversos, intolerância ou contraindicação a pelos menos 4 fármacos preventivos orais prévios (grau de recomendação l). Recomenda ainda que a falência deva ser documentada em calendário, pelo número mensal de crises, e corroborada pela impressão subjetiva do doente.

A seleção dos doentes e o posterior acompanhamento da resposta deve basear-se no calendário das crises e em medidas simples de impacto, avaliados periodicamente pelo menos de 3 em 3 meses.

Os doentes a fazerem preventivos orais podem manter essa terapêutica quando iniciam Acm dado não haver risco de interações e essa associação ter sido permitida nos ensaios clínicos. $O$ objetivo será reduzir a dose e retirá-los assim que melhoria clínica.

\section{Recomendações para a manutenção e interrupção}

Nos ensaios clínicos a maioria dos doentes evidenciou resposta nos três primeiros meses de tratamento. Não há, no entanto, ainda dados sobre qual a duração exata que os tratamentos devem ter nem o que acontece após a interrupção da medicação; sabemos apenas que a administração é segura por períodos prolongados (até aos 3,5 anos) e que o seu efeito é sustentado ${ }^{101}$.

A SPC recomenda que no final do terceiro mês de tratamento seja avaliada a resposta: Se o tratamento estiver a ser eficaz deverá ser mantido; se não houver resposta deve ser interrompido (recomendação grau I).

A SPC recomenda nestes doentes refratários considerar como resposta positiva uma redução de pelo menos $30 \%$ na frequência das crises e melhoria nas medidas centradas no doente.

Enquanto não houver evidência da vida real sobre a duração indicada do tratamento, a SPC recomenda a interrupção do tratamento ao fim de 6 a 12 meses de benefício sustentado (redução $>30 \%$ da frequência das crises) ou melhoria de parâmetros considerados relevantes para o doente (intensidade das crises, resposta aos fármacos agudos, melhoria subjetiva da qualidade de vida e redução do impacto). Deverá também ser reali- zada uma monitorização cuidadosa de segurança com notificação rápida de todos os efeitos secundários.

\section{Farmacocinética, dosagem e modo de administração}

Os Amc-CGRP ou Amc- rCGRP não são absorvidos por via oral, razão pela qual têm que ser administrados por via parentérica (sc ou iv). Os de administração subcutânea podem ser fornecidos em dispositivos de autoadministração. A frequência de administração é mensal ou trimestral conforme o fármaco.

Os anticorpos são catabolizados no sistema reticuloendotelial sendo degradados por proteólise enzimática em pequenos péptidos e aminoácidos. Os pequenos péptidos e aminoácidos formados podem ser reutilizados no organismo para a síntese de novo de proteínas, ou são excretados por via renal. Não são metabolizados pelo fígado nem pelo citocromo $\mathrm{P} 450$ pelo que não têm interações medicamentosas, nomeadamente nem com triptanos nem com anticoncecionais orais.

Uma vez que os anticorpos monoclonais não são eliminados pela via renal e não são metabolizados no fígado, não se prevê que o compromisso renal e hepático afete a sua farmacocinética.

A primeira administração, mesmo quando existe dispositivo de autoadministração, deve ser feito por um profissional de saúde num estabelecimento de saúde. Deve ser administrado apenas em zonas de pele íntegra e sem eritema ou outras alterações.

O erenumab é administrado por via subcutânea, em dispositivo de autoadministração (caneta). A dose eficaz de erenumab são 70 mg; alguns doentes beneficiarão de $140 \mathrm{mg}$ por dia. A sua bioavaliabilidade é de $82 \%$ após administração cutânea. Tem semivida de 28 dias. Pode ser administrado na prega do abdómen, nos membros superiores (se não for autoadministração) ou nas co$\operatorname{xas}^{102}$.

Estão disponíveis dois regimes posológicos para o fremanezumab, ambos para administração subcutânea: 225 mg uma vez por mês (regime mensal) ou 675 mg de três em três meses (regime trimestral). Quando se muda de regime posológico, a primeira dose do novo regime deve ser administrada na próxima data de administração prevista do regime anterior. A sua biodisponibilidade varia entre $55 \%$ a $66 \%$. O fremanezumab pode ser injetado em zonas do abdómen, da coxa ou da parte superior do membro superior. ${ }^{102} \mathrm{O}$ fremanezumab tem uma semivida estimada de 30 dias. 
O galcanezumab, para além locais referidos anteriormente também poder ser administrado na zona glútea. É administrado numa dose inicial de carga de $240 \mathrm{mg}$ na primeira toma a que se segue a a dose de $120 \mathrm{mg}$ mensalmente. A semivida do galcanezumab é de 27 dias. ${ }^{104}$

O eptinezumab é administrado por via ev, numa infusão durante uma hora, na dose de $100 \mathrm{mg}$ trimestralmente. Algum doente poderá beneficiar da dose de 300 $\mathrm{mg}$ trimestral. A sua bioavaliabilidade é de $100 \%$ no final da infusão. A sua semivida é de 27 dias e é atingida uma concentração estável logo na primeira dose trimestral. ${ }^{105}$

As doses não devem ser espaçadas pelo maior risco de produção de Ac neutralizadores ${ }^{106-109}$.

\section{Efeitos secundários}

Os efeitos secundários são pouco frequentes e habitualmente ligeiros não levando à interrupção do tratamento. Podem surgir entre 1\%-10\% e foram semelhantes nos vários ensaios clínicos; menos de $2,0 \%$ descontinuaram o tratamento por efeitos adversos. ${ }^{100-103,110}$

Reações reportadas mais frequentemente foram reações no local da injeção (e apenas 0,5\% descontinuou por essa razão). Essas reações surgem em média até I dia após a administração e desaparecem até aos 5 dias $^{100-103,110}$. Em mais de $80 \%$ dos doentes com dor no local de injeção esta surge em menos de I hora e desaparece ao fim de I dia. Apena I\% dos doentes tem dor severa no local. Embora a reações alérgicas sejam pouco frequentes casos de urticária severa ocorreram e de reações anafiláticas que podem surgir horas até 30 dias após a administração.

Numa metanálise de 10 estudos realizados na $E^{110}$ em doentes entre os 16 e 65 anos, num total de 5817 doentes não se verificaram diferenças na incidência de efeitos adversos graves entre os Acm e o grupo placebo, e nenhum dos eventos graves foi considerado causado pelo $\mathrm{Acm}$. Sintomas que surgiram em mais de $2 \%$ dos participantes foram: infeções respiratórias altas, náuseas, nasofaringite, dor no local da injeção, eritema local, sinusite, tonturas, dores lombares, fadiga, influenza, infeção urinária, obstipação, enxaqueca e artralgias. $\bigcirc$ efeito mais frequentemente reportado foi a infeção respiratória alta em 5,5\% Os únicos efeitos adversos que ocorreram mais frequentemente no grupo dos Acm do que no grupo placebo foram: dor no local da injeção (RRI,32, $p=0,03$ ) e eritema no local da injeção (RRI,55, $p=0,00 \mathrm{I})$. Estas reações foram de caracter ligeiro a mo- derado e bem toleradas. ${ }^{100-103,110}$

O desenvolvimento de Ac neutralizadores ocorrem até $12,5 \%$ aos 12 meses, mas com uma atividade neutralizadora em título baixo e sem influência na farmacocinética.

\section{Contraindicações e precauções}

O CGRP e o seu recetor encontram-se disseminados pelos vasos, trato digestivo, glândula pituitária, pele, SNC e SNP. O CGRP é dos mais potentes vasodilatadores conhecidos. Em teoria, a inibição não específica do CGRP poderia ter efeitos generalizados tais como eventos cardiovasculares agudos, atenuação da vasodilatação compensatória em condições relacionadas com isquémia, úlceras e perturbação da cicatrização das feridas. Foram excluídos dos ensaios ${ }^{100-103}$ doentes com eventos cardiovasculares recentes tais como EAM, angina instável ou doença coronária, AVC e trombose venosa profunda e também doentes acima dos 65 anos (erenumab e galcanezumab), acima dos 70 anos (fremanezumab) e acima dos 75 anos (eptinezumab) pelo que não devem ser utilizados nesses grupos etários e na presença dessas patologias.

Nos vários ensaios clínicos na fase de dupla ocultação, a ocorrência de efeitos adversos cardiovasculares foi semelhante nos doentes tratados com fármacos anti-CGRP e nos que tomaram placebo.

Em relação ao erenumab foi inclusive realizado um estudo clínico em doentes com antecedentes de doença coronária estável a quem foi administrada a dose de 140 mg por via endovenosa e não houve alterações significativa nos resultados da prova de esforço (duração similar do exercício não tendo havido agravamento da isquémia) ${ }^{\prime \prime \prime}$. Nos diferentes ensaios também não se detetaram alterações significativas nos parâmetros vitais, no ECG ou na avaliação laboratorial' ${ }^{\prime 2}$. Também os estudos animais não revelaram efeitos cardiovasculares significativos nem consequências sobre o controle fisiológico da tensão arterial.

Os doentes com toxicodependência, ou com abuso de álcool ou doença mental grave foram excluídos dos ensaios, pelo que por enquanto não se recomenda o uso nestes grupos.

As imunoglobulinas $\mathrm{G}$ atravessam a placenta e não há qualquer dado de segurança da sua utilização na gravidez.

Apesar dos estudos animais não demonstrarem teratogenicidade estes fármacos estão contraindicados na 
gravidez sendo mandatória a utilização de métodos de contraceção eficazes. Devido à sua semivida prolongada, nas mulheres que desejem engravidar é prudente descontinuar estes tratamentos 5 a 6 meses antes da conceção (5 semividas nos casos de administração mensal).

Estão também contraindicados durante a amamentação: as IgG humanas são excretadas no leite materno num período curto, nos primeiros dias após o nascimento, mas com redução rápida nas semanas seguintes.

Desconhece-se o efeito destes fármacos na fertilidade.

\subsection{TERAPÊUTICA DA ENXAQUECA CRÓNICA}

\section{Introdução, enquadramento e objetivos terapêuticos}

A enxaqueca crónica (EC) é uma variante da enxaqueca caracterizada, de acordo com a Classificação Internacional de Cefaleias,' por uma frequência elevada das crises que ocorrem 15 ou mais dias por mês, podendo ser diárias ou quase diárias. As crises devem apresentar as características típicas da enxaqueca (dor de cabeça moderada a intensa, com náuseas/vómitos, foto e fonofobia e responder aos triptanos ou ergotamina) em $\geq 8$ dias por mês. Contudo, nos restantes dias, a cefaleia pode ter características menos específicas, podendo sobrepor-se ao padrão da cefaleia tipo tensão. Para preencher critérios de diagnóstico de EC é ainda necessário que este quadro se mantenha pelo menos três meses.

A EC afeta cerca de $2 \%$ da população e $8 \%$ dos doentes com enxaqueca ${ }^{2,3}$ e, em regra, evolui a partir de formas episódicas da doença. $\bigcirc$ elevado número de crises e o consumo repetido de fármacos para o seu controle sintomático (triptanos, analgésicos, anti-inflamatórios) tendem a provocar abuso medicamentoso/cefaleia por abuso medicamentoso (CAM), uma entidade que se verifica em $30 \%$ a $50 \%$ dos doentes com EC. Por motivos ainda não esclarecidos, estes doentes manifestam também múltiplas comorbilidades como a depressão, ansiedade, dor crónica, obesidade e perturbações do sono ${ }^{4,5}$ que contribuem para o seu sofrimento e podem requerer intervenções terapêuticas específicas. Estudos clínicos e de base populacional mostraram ainda que a enxaqueca crónica está associada a marcada incapacidade, perda de qualidade de vida $^{3,4}$ e a um significativo impacto socioeconómico, sobretudo pelos custos indiretos relacionados com o absentismo/presenteísmo laboral e o consumo de cuidados de saúde. ${ }^{6-8}$

A terapêutica da EC comporta quatro objetivos principais, a) redução da frequência das crises, b) suspensão do abuso medicamentoso, quando este se verifica; c) meIhoria da qualidade de vida e d) redução do impacto da cefaleia na vida familiar, profissional e social do doente.

Uma vez que a enxaqueca crónica inclui diferentes tipos de cefaleias (com e sem as características da enxaqueca) a resposta terapêutica é avaliada e quantificada pela redução do número de dias de enxaqueca e/ou de cefaleias por mês, relativamente à frequência de base. $A$ International Headache Society ${ }^{9}$ recomenda ainda, para ensaios clínicos, que se quantifique a redução mensal dos dias de dor intensa/moderada. Outra forma de avaliar a resposta é pela taxa de respondedores, que na enxaqueca é tradicionalmente definida pela redução $\geq$ a $50 \%$ no número de dias/mês com enxaqueca ou cefaleia moderada/intensa. Adicionalmente (outcomes secundários) a melhoria pode ser avaliada pela taxa de conversão a enxaqueca episódica (EE), pela redução do consumo de fármacos agudos, por medidas de impacto (presenteísmo e absentismo laboral e escalas de impacto) e pela melhoria da qualidade de vida, existindo para esse efeito várias escalas gerais ou específicas para a enxaqueca. Estes têm constituído os principais objetivos dos ensaios clínicos realizados na EC. Contudo, na prática clínica a definição de eficácia requer também o parecer subjetivo do doente, pois o benefício pode englobar aspetos não contemplados nos outcomes, como a redução das idas a serviços de urgência, crises mais curtas ou uma resposta mais rápida e completa à medicação de resgate, entre outros.

A terapêutica da EC é ainda bastante insatisfatória, sobretudo quando associada ao abuso medicamentoso e estas duas entidades constituem as principais causas de cefaleia refratária. Por outro lado, sabe-se que a EC pode ter um curso flutuante com remissões e recidivas. Cerca de $2 \%$ dos doentes por ano remitem para formas episódicas de enxaqueca, o que pode confundir a resposta terapêutica. ${ }^{10}$

\section{Terapêutica}

\section{Medidas gerais}

A enxaqueca é uma doença crónica cujo tratamento requer uma participação ativa e informada dos doentes. A terapêutica deve começar com o diagnóstico e esclarecimentos sobre a natureza da doença e sobre os fato- 
res associados à cronificação, em particular os que são modificáveis. $\bigcirc$ uso excessivo de medicamentos agudos é um dos principais fatores de manutenção e cronificação e deve ser explicitamente discutido com os doentes, reforçando o facto que a sua interrupção melhora a EC e a eficácia dos fármacos preventivos. ${ }^{1,12}$ Outros fatores de risco, a despistar e tratar são as perturbações do sono, a depressão, o consumo excessivo de cafeína e a obesidade. $O$ doente deve ser aconselhado a manter um estilo de vida saudável, com uma dieta equilibrada, exercício físico regular, higiene do sono e, se possível, aprender a gerir situações de stress. Poderá estar indicada a terapêutica antidepressiva/psicoterapia. Deve ser instruído a manter um calendário de crises, onde assinala a sua intensidade e o consumo de fármacos de resgate. Deve-se explicar que o calendário vai servir de base às decisões terapêuticas.

\section{Terapêutica aguda de crise}

O doente deve ser instruído sobre as medidas a tomar durante as crises, circunstância em que tem de decidir de forma autónoma. Existem dados, provenientes da $E E$, que mostram que a medicação é tanto mais eficaz quanto mais precocemente tomada. Contudo nas cefaleias diárias existe o risco de estimular o abuso medicamentoso.

$\mathrm{Na}$ ausência de estudos específicos, dirigidos ao tratamento agudo da EC, recomendam-se os fármacos habitualmente usados nas formas episódicas de enxaqueca. $O$ doente tem de conhecer os limites da medicação aguda e reservá-la para as crises mais intensas e incapacitantes. $O$ consumo de triptanos, analgésicos combinados ou opioides não deve ultrapassar os 10 dias por mês e o consumo de analgésicos simples e anti-inflamatórios não esteroides não deve ir além dos quinze dias por mês. Os opióides não estão recomendados. Aguarda-se a comercialização de novos fármacos (como os agonistas 5 HTIF ou os gepants) que poderão ser mais seguros e eficazes do que os fármacos atualmente disponíveis.

Também podem ser úteis as medidas não farmacológicas, como a aplicação de frio (ou calor) local, o repouso em local isolado, se possível, e não insistir no esforço em plena crise, medidas que são ajustadas a cada caso. A intervenção sobre o abuso medicamentoso é explicada na respetiva secção deste manual.

\section{Terapêutica preventiva na enxaqueca crónica}

Todos os doentes com EC têm indicação para terapêutica profilática. $A$ redução do número de crises é considerada essencial, na medida em que a frequência elevada é o principal fator de cronificação da enxaqueca $(O R=20, I) \cdot{ }^{13}$ No entanto, em estudos de base populacional apenas 33\% dos casos de EC estão medicados com preventivos.

Existem apenas três terapêuticas preventivas com um nível de evidência $A$ (de acordo com a DGS ${ }^{14}$ ) na EC: o topiramato, a toxina onabotulínica tipo A e os anticorpos monoclonais dirigidos ao CGRP ou ao seu recetor, das quais apenas a toxina está especificamente aprovada para prevenção da EC em adultos. Além disso, e porque o reconhecimento da EC como entidade nosológica é relativamente recente, existem poucos ensaios clínicos na EC com os fármacos usados na prevenção oral da EE.

A escolha do tratamento é individualizada, de acordo com o perfil do doente, as suas comorbilidades e falências terapêuticas prévias. Contudo, mesmo com terapêuticas personalizadas, apenas 17\%-20\% dos doentes mantêm a medicação prescrita ao fim de um ano, ${ }^{15-17}$ por efeitos adversos, intolerância e ausência de resposta. A baixa adesão condiciona mudanças repetidas de tratamento, o controlo inadequado da doença e o esgotar das opções terapêuticas. São classificadas como falências terapêuticas (e indicação para mudar de medicação), a ausência/insuficiência de resposta após um período de medicação em dose e duração adequadas, os efeitos adversos, as contraindicações e as questões de segurança que impeçam o uso do fármaco. ${ }^{9}$

\section{a) Preventivos orais}

I. Topiramato (nível de evidência A) (vidé capítulo 3.3.2.A.3)

\section{Mecanismo de acção}

O topiramato é um fármaco anti-epiléptico que inibe os canais de sódio dependentes da voltagem, potencia - GABA, é antagonista dos recetores do glutamato e inibe a anidrase carbónica eritrocitária. Pensa-se que a sua eficácia na prevenção da enxaqueca resulta do efeito neuromodulador sobre a excitabilidade neuronal.

\section{Evidência}

topiramato foi estudado em dois ensaios clínicos aleatorizados e controlados com placebo em doentes com EC, com ou sem CAM, num dos quais os doentes 
podiam manter outros profiláticos desde que em dose estável $^{18,19}$ (Tabela 3.4.I). O fármaco foi eficaz na redução do número de dias com enxaqueca, ${ }^{18,19}$ na redução $\geq 50 \%$ dos dias com enxaqueca/mês, ${ }^{18}$ na melhoria da foto/fonofobia ou do agravamento pelo esforço, ${ }^{20}$ em medidas de impacto, avaliado pela escala MIDAS $^{19}$ e nalguns aspetos da qualidade de vida. ${ }^{20}$ Numa análise conjunta dos dois ensaios verificou-se ainda que o topiramato foi eficaz tanto em doentes com abuso medicamentoso como sem abuso. ${ }^{21}$

Tabela 3.4.1. Ensaios clínicos do topiramato na enxaqueca crónica

\begin{tabular}{|c|c|c|c|c|c|c|c|}
\hline $\begin{array}{l}\text { Ensaio } \\
\text { (recruta- } \\
\text { mento) }\end{array}$ & $\begin{array}{l}\mathrm{N} \\
\text { (Topiramato } \\
+ \text { placebo } \\
=\text { total) }\end{array}$ & $\begin{array}{l}\text { Associação } \\
\text { a outros } \\
\text { preventivos } \\
\text { orais }\end{array}$ & $\begin{array}{l}\text { Casos com } \\
\text { abuso medi- } \\
\text { camentoso }\end{array}$ & $\begin{array}{l}\text { Dose alvo } \\
\text { (mín-máx) } \\
\text { Dose média }\end{array}$ & $\begin{array}{l}\text { Outcomes } \\
\text { positivos }\end{array}$ & $\begin{array}{l}\text { Efeitos adversos } \\
\text { (\%) } \\
\text { (topiramato vs } \\
\text { placebo) }\end{array}$ & $\begin{array}{l}\text { Descontinuação } \\
\text { (topiramato vs } \\
\text { placebo) }\end{array}$ \\
\hline $\begin{array}{l}\text { Silberstein } 2007 \\
(E \cup A)^{19}\end{array}$ & $153+153=306$ & $\begin{array}{l}\text { Não } \\
\text { permitida }\end{array}$ & $37,6 \%$ & $\begin{array}{l}100 \mathrm{mg} / \mathrm{dia} \\
(50-100) \\
86 \pm 29 \\
\mathrm{mg} / \mathrm{dia}\end{array}$ & $\begin{array}{l}\text { Redução número } \\
\text { médio mensal de } \\
\text { dias com enxaqueca } \\
\text { + ou dor migranosa } \\
\text { (topiramato }-6,4 \\
\text { vs placebo }-4,7 \text {, } \\
p=0,010 \text { ) e dias } \\
\text { com enxaqueca } \\
\text { (topiramato }-5,6 \\
\text { vs placebo }-4.1 \text {, } \\
p=0,032 \text { ) }\end{array}$ & $\begin{array}{l}\text { topiramato } 82,5 \% \\
\text { placebo } 70,2 \% \\
\text { parestesias } 28,8 \% \text {; } \\
\text { insuficiência } \\
\text { respiratórias } 13,8 ; \\
\text { fadiga } 11,9 \%\end{array}$ & $\begin{array}{l}44,2 \% \text { topiramato } \\
\text { vs } \\
44,8 \% \text { placebo } \\
\text { (por efeitos } \\
\text { adversos } 10 \% \\
\text { topiramato e } 6 \% \\
\text { placebo) }\end{array}$ \\
\hline
\end{tabular}

\section{Doses e forma de administração e titulação}

A terapêutica inicia-se com uma toma única diária de 15 a $25 \mathrm{mg} / \mathrm{dia}$, que é titulada com aumentos semanais de $25 \mathrm{mg}$ até aos $100 \mathrm{mg}$ (ou até à dose máxima tolerada) podendo atingir, no máximo, $200 \mathrm{mg} / \mathrm{dia} .{ }^{18} \mathrm{~A}$ titulação e estabilização da dose (redução por baixa tolerância, aumento por resposta insuficiente) pode demorar semanas a atingir e a resposta terapêutica pode não ser imediata, mas não existem dados disponíveis sobre a percentagem de respondedores por mês de terapêutica. Num dos ensaios, o início da eficácia (i.e., da diferença significativa entre topiramato e placebo) verificou-se às 4 semanas, ou seja, após o final da titulação, mas o benefício máximo verificou-se entre as 12 e as 16 semanas, período em que a dose diária se manteve estável. ${ }^{18}$ Estes dados parecem indicar que o benefício do topiramato na EC é máximo aos 3 ou 4 meses de terapêutica estável. Na prática, alguns doentes respondem a doses baixas ( $25 \mathrm{mg}$ ), inferiores aos $50 \mathrm{mg}$ diários prescritos nos ensaios, enquanto noutros é necessário ultrapassar os 100 mg diários.

\section{Contraindicações}

O topiramato está contraindicado nos doentes com litíase renal e no glaucoma, pelo risco de aumentar a pressão ocular. Não deve ser prescrito na gravidez, nem em mulheres que pretendem engravidar, nem durante a amamentação.

\section{Tolerabilidade e adesão terapêutica}

$\mathrm{Na}$ EC existe uma baixa adesão e baixa tolerabilidade à terapêutica com topiramato por efeitos adversos ou ineficácia. Em estudos de vida real apenas $23 \%$ e $12 \%$ dos doentes mantiveram a terapêutica aos seis meses e ao fim de um ano, respetivamente. ${ }^{16,17}$ Nos ensaios clínicos, a taxa de abandono no braço ativo variou entre os $25 \%$ e os $48 \%$.

\section{Efeitos adversos e precauções}

Os efeitos adversos, mais reportados são as parestesias das extremidades ( $53 \%$ casos), náusea ( $9 \%$ ), perda do apetite e do paladar, perda de peso, efeitos na cognição (perda de atenção, da capacidade de concentração, dificuldade de evocação de nomes) e no humor (depres- 
são, irritabilidade) e fadiga, efeitos que limitam o seu benefício. Em doses elevadas o topiramato pode interferir com a eficácia dos contracetivos orais, aspeto que deve ser abordado com as doentes, aconselhando-se nesses casos o reforço das medidas contracetivas.

\section{Recomendações para o início, manutenção e interrupção}

O topiramato deve ser considerado como fármaco de primeira linha na prevenção da enxaqueca crónica, a menos que existam contraindicações ou intolerância (recomendação de grau $\mathrm{I}^{14}$ ). A interrupção da terapêutica deve ser feita:

a) Por efeitos adversos, graves ou não toleráveis.

b) Por resposta insuficiente ou ausente após atingir a dose máxima tolerada de forma estável (ou seja, excluindo o período de ajuste terapêutico). O tempo mínimo de terapêutica (em dose alvo/recomendada) para definir falência não está estabelecido. A Sociedade Americana de Cefaleias (AHS) ${ }^{22}$ recomenda, para a EC, um mínimo de 8 semanas sem resposta com a dose alvo/ dose habitualmente recomendada, para mudar de preventivo oral. A SPC recomenda que se possa mudar de terapêutica oral ao fim de 8 semanas com a dose máxima tolerada, não havendo resposta objetiva ou percecionada pelo doente. Contudo, se possível, a resposta deve ser avaliada até às 12 semanas para dar oportunidade de atingir o período de benefício máximo, de acordo com os resultados dos ensaios (recomendação grau lla). A melhoria objetiva deve ser documentada em calendário.

Havendo melhoria subjetiva ou objetiva (redução $\geq 50 \%$ na frequência das crises) a terapêutica deve ser mantida durante um período de 6 a 12 meses, após o qual se procede à retirada progressiva no espaço de I - 2 meses, sob vigilância clínica. Não existem estudos que demonstrem vantagem na manutenção durante mais tempo, contudo não existe consenso sobre estes prazos. Não existe evidência sobre o benefício da manutenção terapêutica quando a resposta é parcial, por exemplo uma redução da frequência das crises $\geq 30 \%$ $<50 \%$, redução da intensidade ou da duração das crises, ou melhor resposta à medicação aguda, sendo importante ouvir o parecer subjetivo do doente. Recomenda-se que seja dada ao doente a hipótese de obter benefício cumulativo durante 6 a 12 meses de uso mantido.

\section{Outros preventivos orais}

À exceção do topiramato, não existe evidência suficiente na EC, sobre a eficácia dos outros preventivos orais usados na enxaqueca episódica. Mas, na prática aplicam-se aos outros preventivos aprovados para a EE as regras acima definidas para o topiramato.

Existem outros estudos disponíveis, efetuados em pequenos ensaios abertos ou em pequenas séries (pregabalina, minalcipran, atenolol, zonizamida, duloxetina, memantina) ou num único ensaio clínico aleatorizado e controlado (valproato de sodio, amitriptilina, gabapentina, tizanidina) insuficientes para a sua recomendação ${ }^{23}$. mesmo se aplica à combinação de preventivos, embora seja prática comum manter os fármacos que se traduzem nalgum benefício, mesmo que insuficiente. Num ensaio controlado com placebo em doentes insuficientemente controlados com topiramato, não se verificou vantagem na adição de propranolol de longa acção ${ }^{24}$.

\section{b) Toxina botulínica (toxina onabotulinica A, BoNTA)} (Nível de evidência A)

\section{Mecanismo de acção}

Além de interferir com a transmissão neuromuscular, a toxina botulínica inibe a libertação local de neurotransmissores nociceptivos (CGRP, substância P, glutamato) a partir das terminações nervosas sensitivas. Quando é injetada em vários pontos do couro cabeludo e da região cervico-escapular, ela vai bloquear a transmissão nociceptiva a partir das fibras $C$ não mielinizadas do trigémeo. Estudos em animais mostraram ainda que a toxina sofre um transporte axonal retrógrado a partir das terminações nervosas periféricas, podendo assim modular a via nociceptiva a nível mais central no complexo trigémino-cervical. Estes efeitos explicam a eficácia da toxina na EC. Curiosamente, a toxina não é eficaz na enxaqueca episódica, o que leva a crer que o seu mecanismo de acção na EC esteja sobretudo relacionado com a reversão da sensibilização periférica e central no sistema nociceptivo trigémino vascular.

\section{Evidência}

Existe uma evidência muito consistente, de nível $A^{14}$ sobre a eficácia da toxina onabotulinica $A$ (BoNTA) na EC resultante de ensaios controlados com placebo ${ }^{25-27}$ 
(Tabela 3.4.2), uma meta-análise, ${ }^{28}$ estudos de seguimento a longo prazo, ${ }^{29}$ estudos de vida real ${ }^{30,31}$ e ensaios com comparador ativo. ${ }^{32}$ Toda a evidência provém de estudos realizados com a BoNTA e de acordo com o protocolo de administração do ensaio PREEMPT. ${ }^{25}$

A toxina foi eficaz quer na redução mensal dos dias com cefaleia e com enxaqueca, quer em medidas de impacto e qualidade de vida, ${ }^{25-27}$ mas não na redução do consumo de fármacos agudos. ${ }^{27,33}$ Cerca de $50 \%$ dos doentes respondeu à primeira sessão, mais 10\% à segunda sessão e igual percentagem à terceira, podendo-se esperar benefício em dois terços dos doentes à terceira sessão. ${ }^{34}$ Verificou-se uma melhoria significativa em várias medidas, comparativamente ao placebo um mês após a primeira administração e, nos estudos de longo prazo a eficácia manteve-se até aos 2 anos, observando-se mesmo um benefício cumulativo com a repetição das sessões. ${ }^{29-31}$ Análises pos hoc realizadas em subgrupos específicos mostraram que a BonTA é eficaz em doentes com falências terapêuticas prévias ${ }^{35}$ e em doentes com abuso medicamentoso. ${ }^{33}$ Contudo, a BonTA não parece trazer vantagem aos protocolos de suspensão de abuso medicamentoso. ${ }^{36}$ Esta terapêutica também tem apresentado resultados positivos em estudos de custo-eficácia. Num estudo comparativo com o topiramato, a toxina revelou superioridade por maior adesão terapêutica e escassez de efeitos adversos. ${ }^{32}$

Tabela 3.4.2. Ensaios clínicos pivotais da toxina botulínica na enxaqueca crónica

\begin{tabular}{|c|c|c|c|c|c|c|c|}
\hline $\begin{array}{l}\text { Ensaio } \\
\text { (local de } \\
\text { recruta- } \\
\text { mento) }\end{array}$ & $\begin{array}{l}\mathbf{N} \\
\text { (toxina } \\
+ \text { placebo } \\
\text { = total) }\end{array}$ & Duração & $\begin{array}{l}\text { Casos com } \\
\text { abuso medi- } \\
\text { camentoso }\end{array}$ & $\begin{array}{l}\text { Dose } \\
\text { (mín-máx) }\end{array}$ & $\begin{array}{l}\text { Outcomes } \\
\text { positivos }\end{array}$ & $\begin{array}{l}\text { Efeitos adversos } \\
\text { Relacionados com a } \\
\text { terapêutica }\end{array}$ & $\begin{array}{l}\text { Descontinuação } \\
\text { Por efeitos } \\
\text { adversos } \\
\text { (toxina vs } \\
\text { placebo) }\end{array}$ \\
\hline $\begin{array}{l}\text { Aurora et al } \\
2010 \\
\text { PREEMPT-I } \\
(\text { EUA) }\end{array}$ & $341+338=679$ & $\begin{array}{l}24 \text { semanas } \\
\text { dupla- } \\
\text { mente } \\
\text { cego }+32 \\
\text { semanas } \\
\text { fase aberta }\end{array}$ & $\begin{array}{l}66 \% \text { (toxina) } \\
69 \% \\
\text { (placebo) }\end{array}$ & $\begin{array}{l}155-195 \mathrm{U} \\
\text { cada } 12 \\
\text { semanas }\end{array}$ & $\begin{array}{l}\text { Outcomes } \\
\text { secundários: } \\
\text { Redução número } \\
\text { médio mensal de } \\
\text { dias com cefaleias } \\
\text { ( } p=0,006) \text { e com } \\
\text { enxaqueca }(p=0,002)\end{array}$ & $\begin{array}{l}\text { Toxina } 25,3 \% \\
\text { (5,9\% dor cervical; } \\
5,9 \% \text { fraqueza } \\
\text { muscular local) } \\
\text { Placebo } 11,7 \%\end{array}$ & $\begin{array}{l}4,1 \% \\
\text { vs } \\
0,9\end{array}$ \\
\hline $\begin{array}{l}\text { Diener et al, } \\
2010 \\
\text { PREEMPT-II } \\
\text { (Europa) }^{26}\end{array}$ & $\begin{array}{l}347+358= \\
705\end{array}$ & $\begin{array}{l}24 \text { semanas } \\
\text { dupla- } \\
\text { mente } \\
\text { cego }+32 \\
\text { semanas } \\
\text { fase aberta }\end{array}$ & $\begin{array}{l}63,4 \% \\
\text { (toxina) } \\
62,6 \% \\
\text { (placebo) }\end{array}$ & $\begin{array}{l}155-195 \mathrm{U} \\
\text { cada } 12 \\
\text { semanas }\end{array}$ & $\begin{array}{l}\text { Redução número } \\
\text { médio mensal de } \\
\text { dias com cefaleia vs } \\
\text { baseline (toxina }-9,0 \\
\text { vs placebo - } 6,7, \\
p=0,001 \text { ) medidas } \\
\text { de impacto e } \\
\text { qualidade de vida }\end{array}$ & $\begin{array}{l}\text { Toxina } 33,3 \% \\
\text { (7,5\% dor cervical; } \\
5,2 \% \text { fraqueza } \\
\text { muscular local) } \\
\text { Placebo } 13,7\end{array}$ & $\begin{array}{l}3,5 \% \text { toxina } \\
\text { vs } \\
1,4 \% \text { placebo }\end{array}$ \\
\hline
\end{tabular}

\section{Doses e forma de administração}

O protocolo recomendado para a administração da BoNTA na EC é o do estudo PREEMPT. ${ }^{25}$ A toxina é injetada em 3 |-39 pontos, 3 I dos quais são fixos (distribuídos simetricamente no couro cabeludo e na região cervico-escapular de forma a cobrir o território dos principais nervos sensitivos) e 8 são pontos opcionais a distribuir em 3 grupos musculares, à discrição do clínico e seguindo os locais de dor. A dose é de cinco unidades de BoNTA por ponto, correspondendo a um total de 155-195 unidades. Não havendo resposta às 155 unidades, pode-se aumentar a dose para 195 unidades. As sessões terapêuticas são rápidas e não requerem anestesia. Deve-se recomendar ao doente para não massajar os pontos injetados nas horas que se seguem à administração. As sessões são repetidas a intervalos de 12 semanas, correspondente ao tempo médio de semivida da toxina. $O$ início da acção (assim como os efeitos adversos sobre a transmissão neuromuscular) verifica-se dez a quinze dias pós sessão. $O$ efeito tende a diminuir à aproximação da sessão seguinte. Quando se inicia a terapêutica com toxina podem manter-se os preventivos orais em curso, desde que tenha havido benefício ainda que parcial, mas o objetivo será baixar a dose/ retirá-los quando se verificar resposta à toxina, o que se consegue em cerca de metade dos doentes. ${ }^{37}$

\section{Contraindicações e precauções}

A toxina está contraindicada nas pessoas com doenças da transmissão neuromuscular e também, por ausência de dados de segurança, na gravidez. A administração deve ser feita com particular cuidado em doentes 
com soluções de continuidade do crânio (craniotomia, shunts, etc). A antiagregação e a anticoagulação não constituem contraindicação, embora requeiram mais cuidado e vigilância na administração.

\section{Efeitos adversos}

A toxina botulínica é um fármaco bastante seguro, com efeitos adversos sobretudo locais (dor à injeção, hematoma no local injetado) ou resultantes do bloqueio neuromuscular (dor cervical, falta de força, ptose, alteração da mímica facial), que são reversíveis.

\section{Recomendações para o início e a suspensão terapêutica}

A toxina botulínica é geralmente considerada uma terapêutica profilática de segunda linha na EC, após os preventivos orais. ${ }^{35,37,38}$ Está indicada nos doentes que não tiveram benefício suficiente, que tiveram efeitos adversos ou que têm contraindicação para os preventivos orais. $\bigcirc$ número mínimo de falências de preventivos orais para iniciar toxina não é consensual. A Federação Europeia de Cefaleias (EHF)38 recomenda falência $\geq 2$ a 3 dos profiláticos orais (com redução das crises $<30 \%$ ), a Sociedade Espanhola de Cefaleias requer a falência $\geq 2$ preventivos (incluindo um beta bloqueante e o topiramato) em dose mínima recomendada e pelo menos durante 3 meses ${ }^{37}$ e no Reino Unido o NICE recomenda o início de BoNTA após falência $\geq$ a 3 preventivos orais. ${ }^{35}$ Se o doente tem abuso medicamentoso a EHF recomenda que tente suspender o abuso antes do início da toxina ${ }^{38}$ mas, não sendo possível pode-se iniciar a BoNTA antes de interromper o abuso.

A SPC recomenda (recomendação de grau I'4) a terapêutica com BoNTA para a EC em segunda linha, após falência/contraindicação/efeitos adversos a dois ou mais preventivos, um dos quais deve ser o topiramato, que devem ter sido tomados nas doses recomendadas pelo menos 8 semanas, mas idealmente 12 semanas. Recomenda ainda que a falência deva ser documentada em calendário, pelo número mensal de crises, e corroborada pela impressão subjetiva do doente.

\section{Manutenção e suspensão da terapêutica}

Embora não exista consenso sobre todos os critérios para a suspensão da BoNTA, esta deve ser considerada:

a) Em casos de intolerância à administração ou efeitos adversos graves ou persistentes, gravidez de novo e recusa do doente em continuar b) Quando não existe resposta após um mínimo de três sessões ( 9 meses) pois, como foi mencionado, $20 \%$ dos doentes só irão responder à segunda ou à terceira dose. Não havendo resposta à primeira sessão pode-se aumentar a dose de BoNTA para 195 unidades nas sessões seguintes.

c) Quando existe benefício mantido, ou seja pelo menos seis meses de resposta (duas sessões seguidas), com redução do número de dias de dor (redução $>30 \%$ da frequência das crises, ou passagem a formas de enxaqueca episódica, mas não muito frequente com $<8$ dias de dor por mês), ou melhoria de parâmetros considerados relevantes para o doente (intensidade das crises, resposta aos fármacos agudos, melhoria subjetiva, da qualidade de vida, redução do impacto). Esta melhoria pode ocorrer após as primeiras 3-4 sessões ou ao fim de vários meses, uma vez que o efeito é cumulativo. Poder-se-á iniciar um espaçamento das sessões de I mês (3 sessões/ano) e ir vigiando a resposta.

\section{Anticorpos monoclonais dirigidos ao CGRP ou ao recetor (Amc-CGRP e Amc-rCGRP) (Nível de} evidência A) (vidé capítulo 3.3.2.B.2)

Os anticorpos monoclonais (Amc) constituem a intervenção mais recente e porventura mais inovadora na prevenção da enxaqueca. Difere das terapêuticas prévias não só pelo mecanismo de acção como também pelo fundamento científico que a suporta. De facto, enquanto os preventivos orais resultam essencialmente de dados empíricos, os Acm foram especificamente desenvolvidos para intervir nos mecanismos fisiopatológicos da doença, após o reconhecimento do papel pivotal do CGRP no sistema trigémino-vascular e na mediação das crises. ${ }^{39} \mathrm{O}$ leitor deve consultar o capítulo referente a estes fármacos no tratamento da EE no que concerne a modo de acção destes fármacos e do papel do CGRP nas crises de enxaqueca.

$\mathrm{Na}$ enxaqueca episódica o CGRP é libertado durante as crises, com elevação dos níveis séricos na veia jugular ipsilateral à dor, enquanto na enxaqueca crónica os seus níveis estão persistentemente elevados. Esta evidência clínica, assim como os estudos experimentais realizados em animais, levaram ao desenvolvimento de fármacos anti-CGRP para o tratamento da enxaqueca.

Neste momento existem quatro anticorpos monoclonais contra o CGRP (Amc-CGRP ou Amc-rCGRP) cujas características, doses, forma e frequência de ad- 
ministração se encontram listadas na Tabela 3.3.4. Os Amc-CGRP ou Amc-rCGRP não são absorvidos por via oral, razão pela qual têm que ser administrados por via parentérica (SC ou EV). A frequência de administração é mensal ou trimestral, conforme o tempo de semivida. Não atravessam a barreira hemato-encefálica e pensa-se que o seu efeito na prevenção da enxaqueca resulta do efeito periférico, no gânglio do trigémeo.

\section{Evidência}

Enquanto grupo terapêutico, estes fármacos no seu conjunto produziram resultados muito consistentes e idênticos, resultando num nível de evidência $A$. Todos os ensaios clínicos de fase $2 \mathrm{~b} / 3$ (controlados com placebo, aleatorizados e em dupla ocultação) realizados na enxaqueca crónica com Amc-CGRP ou Amc-rCGRP foram positivos. ${ }^{40-44}$ Os resultados dos ensaios pivotais encontram-se resumidos na Tabela 3.4.3. Os resultados não são inteiramente comparáveis nem no outcome primário, nem na seleção dos doentes, limites de idade incluídos, uso de preventivos orais concomitantes, percentagem de doentes com abuso medicamentoso ou falências prévias a preventivos e ainda não existem estudos de comparação direta entre os vários Amc-CGRP.
O objetivo primário mais frequente foi a redução do número de dias com enxaqueca ou com cefaleia por mês (nalguns estudos ${ }^{43}$ definidos como cefaleia moderada a severa, mais longa ou que requereu o uso de medicação específica) mas num deles foi a redução $\geq 75 \%$ dos dias com enxaqueca. ${ }^{40,41}$ Foram usados diferentes outcomes secundários entre os quais a percentagem de doentes com uma redução superior a $50 \%$ dos dias com cefaleias ou enxaqueca e medidas de eficácia centradas no doente (qualidade de vida, impacto, absentismo, etc). Todos os ensaios confirmaram o benefício destes fármacos na maioria das medidas de outcome..$^{40-45}$ No estudo com eptinezumab, verificou-se uma redução das crises nas primeiras 24 horas pós infusão ${ }^{46}$ e ainda que cerca de $7 \%$ dos doentes ficou sem crises no primeiro mês, aumentando para 13\%-14\% no segundo e no terceiro mês. ${ }^{40}$ Nos outros Amc-CGRP a eficácia manifestou-se desde a primeira semana de terapêutica. Outros parâmetros, como o impacto, obtiveram resposta máxima pelas 12 semanas. Estes dados apontam para uma resposta inicial rápida, mas que aumenta ao longo dos primeiros três meses. Nalguns estudos, verificou-se também uma redução significativamente superior a placebo no consumo de fármacos agudos de crise. ${ }^{42,43}$

Tabela 3.4.3. Ensaios de anticorpos monoclonais anti CGRP e anti rCGRP na enxaqueca crónica

\begin{tabular}{|c|c|c|c|c|c|c|c|c|c|}
\hline $\begin{array}{l}\text { Anticorpo } \\
\text { monoclonal } \\
\text { anti CGRP }\end{array}$ & Ensaio & $\begin{array}{l}\mathrm{N} \\
\mathrm{GE} \\
\mathrm{Plc}\end{array}$ & Dose/s & $\begin{array}{l}\text { Tempo até } \\
\text { ao outcome } \\
\text { primário }\end{array}$ & $\begin{array}{l}\text { Outcome } \\
\text { primário }\end{array}$ & $\begin{array}{l}\text { Responde- } \\
\text { dores: } \\
\text { redução } \geq \\
\text { de } 50 \% \text { dias } \\
\text { de cefaleia / } \\
\text { enxaqueca / } \\
\text { mês }\end{array}$ & $\begin{array}{l}\text { Preventivos } \\
\text { orais } \\
\text { concomi- } \\
\text { tantes }\end{array}$ & $\begin{array}{l}\text { Subgrupos } \\
\text { específicos } \\
\text { incluídos }\end{array}$ & $\begin{array}{l}\text { Existência } \\
\text { de dados de } \\
\text { seguimento } \\
\text { longo termo }\end{array}$ \\
\hline Eptinezumab & $\begin{array}{l}\text { PROMISE } 2 \\
\text { Fase } 2 b^{40}\end{array}$ & $\begin{array}{l}122 \\
121 \\
122 \\
130 \\
\text { Plc121 }\end{array}$ & $\begin{array}{l}\text { Dose única } \\
\text { de } \\
100 \mathrm{mg} \text { ou } \\
300 \mathrm{mg} \\
30 \mathrm{mg} \\
10 \mathrm{mg}\end{array}$ & $\begin{array}{l}\text { Todo o } \\
\text { período de } \\
1-12 \text { semanas }\end{array}$ & $\begin{array}{l}\text { Redução } \\
\geq 75 \% \text { dos } \\
\text { dias/mês } \\
\text { com } \\
\text { enxaqueca }\end{array}$ & $\begin{array}{l}\text { Enxaqueca } \\
55,1 \% \\
57,0 \% \\
55,6 \% \\
43,9 \% \text { ns } \\
40,5 \%\end{array}$ & $\begin{array}{l}35 \% \text {-faziam } \\
\text { preventivos } \\
\text { em dose } \\
\text { estável nos } \\
3 \text { últimos } \\
\text { meses }\end{array}$ & $\begin{array}{l}\text {-Abuso medi- } \\
\text { camentoso }\end{array}$ & Não \\
\hline Erenumab & Fase $2^{42}$ & $\begin{array}{l}188 \\
187 \\
\text { Plc281 }\end{array}$ & $\begin{array}{l}70 \mathrm{mg} \\
140 \mathrm{mg}\end{array}$ & 9-12 semanas & $\begin{array}{l}\text { Redução } \\
\text { dias/ } \\
\text { mês com } \\
\text { enxaqueca }\end{array}$ & $\begin{array}{l}\text { Enxaqueca } \\
40 \% \\
41 \% \\
23 \% \mathrm{Plc}\end{array}$ & $\begin{array}{l}\text { Não foram } \\
\text { permitidos } \\
\text { preventivos } \\
\text { durante e } 2 \\
\text { meses antes } \\
\text { ensaio }\end{array}$ & $\begin{array}{l}-41 \% \text { Abuso } \\
\text { medi- } \\
\text { camentoso } \\
-68 \% \text { não } \\
\text { responderam } \\
\leq 3 \\
\text { preventivos }\end{array}$ & $\begin{array}{l}\text { Sim } \\
\text { Estudo de um } \\
\text { centro (55) }\end{array}$ \\
\hline Fremanezumab & $\begin{array}{l}\text { HALO_CM } \\
\text { Fase } 3^{43}\end{array}$ & $\begin{array}{l}376 \\
379 \\
\text { Plc375 }\end{array}$ & $\begin{array}{l}675 \mathrm{mg} \\
675 \mathrm{inicial+} \\
225 \mathrm{mg} / \mathrm{mês} \\
\mathrm{Plc}+\mathrm{Plc}+\mathrm{Plc}\end{array}$ & 12 semanas & $\begin{array}{l}\text { Redução } \\
\text { dias cefaleia } \\
\text { moderada- } \\
\text { severa/mês }\end{array}$ & $\begin{array}{l}\text { Cefaleias } \\
37,6 \% \\
40,8 \% \\
\\
18,1 \% \mathrm{Plc}\end{array}$ & $\begin{array}{l}21 \% \text { faziam } \\
\text { preventivos } \\
\text { orais em } \\
\text { dose estável }\end{array}$ & $\begin{array}{l}\text {-Abuso medi- } \\
\text { camentoso } \\
\text { - Falência } \\
\text { prévia a } 1 \\
\text { preventivo }\end{array}$ & $\begin{array}{l}\text { Sim } \\
\text { até } 12 \text { aos } \\
\text { meses } \\
(\mathrm{N}=1110)\end{array}$ \\
\hline Galcanezumab & $\begin{array}{l}\text { REGAIN } \\
\text { Fase } 3^{44}\end{array}$ & $\begin{array}{l}278 \\
277 \\
\text { Plc558 }\end{array}$ & $\begin{array}{l}240 \mathrm{mg} \\
\text { inicial+ } 120 \\
\mathrm{mg} / \mathrm{mês} \\
240 \mathrm{mg} / \mathrm{mês} \\
\mathrm{Plc}\end{array}$ & 4-12 semanas & $\begin{array}{l}\text { Redução dias } \\
\text { de /mês } \\
\text { com } \\
\text { enxaqueca }\end{array}$ & $\begin{array}{l}\text { Cefaleias } \\
37,6 \% \\
40,8 \% \\
18,1 \% \mathrm{Plc}\end{array}$ & $\begin{array}{l}13 \%-16 \% \\
\text { topiramato ou } \\
\text { propranolol } \\
\text { em dose } \\
\text { estável }\end{array}$ & $\begin{array}{l}-64 \% \text { Abuso } \\
\text { medi- } \\
\text { camentoso } \\
-76 \%-79 \% \\
\text { Falências } \\
\text { prévias } \leq 2\end{array}$ & $\begin{array}{l}\text { Fase aberta } \\
\text { mais } 9 \mathrm{~m} \\
(51,54) \\
+6 \text { meses }(55)\end{array}$ \\
\hline
\end{tabular}

$\mathrm{GE}=$ grupos de estudo (com fármaco activo); $\mathrm{Plc}=$ placebo 
A maioria dos ensaios na enxaqueca crónica permitiam a inclusão de doentes com formas mais graves e complexas de EC, com abuso medicamentoso, falência prévia a $1,{ }^{43}$ até $2^{44}$ ou até $3^{42}$ terapêuticas preventivas orais e alguns $\mathrm{s}^{40,43,44}$ permitiam que uma percentagem de doentes se mantivesse sob preventivos orais durante o estudo, desde que em dose estável (Tabela 3.4.3). As análises pós-hoc destes subgrupos específicos confirmaram a sua eficácia. $O$ erenumab foi eficaz na EC com o abuso medicamentoso ${ }^{48}$ e o erenumab, o fremanezumab e o galcanezumab em doentes com falências prévias de preventivos orais, ${ }^{49,50}$ mostrando até maior eficácia nesses doentes por menor efeito placebo. ${ }^{51} \mathrm{Ve}$ rificaram-se também resultados favoráveis em estudos de custo-eficácia. ${ }^{52}$ Em estudos de seguimento até aos 6 meses ou ano, ${ }^{53,54}$ um deles com uma pequena amostra, ${ }^{55}$ foi possível corroborar o perfil de segurança observado nos ensaios iniciais e observou-se a manutenção do efeito no que respeita à redução do número de dias de dor, dias com enxaqueca e em medidas centradas no doente (impacto, absentismo, presenteismo laboral, qualidade de vida).

Embora o benefício possa ser considerado modesto, quando subtraído o efeito placebo (diferença até -2,5 dias/mês), a verdade é que esse benefício é valorizado pelos doentes, pois pode ainda associar-se a crises menos intensas, mais curtas, com menor recurso a analgésicos e menor consumo de cuidados de saúde.

As principais vantagens dos Acm-CGRP e Acm-rCGRP que sobressaem destes ensaios, são o início rápido de efeito, não terem necessidade de titulação, a facilidade de administração e o perfil de segurança e tolerabilidade. Aguardam-se estudos de vida real para compreender a segurança, a resposta e a sua manutenção a longo prazo em doentes com outras comorbilidades como a depressão/ansiedade, fibromialgia, doenças autoimunes, vasculares ou gastrointestinais. Será importante identificar os doentes com maior probabilidade de resposta e compreender as diferenças entre os Amc dirigidos ao ligando ou ao receptor do CGRP, em termos de resposta e perfil de efeitos adversos.

\section{Farmacocinética, dosagens e forma de administração}

Vidé capítulo 3.3.2.B.2 (tratamento preventivo da EE) e Tabela 3.3.4

\section{Contraindicações e precauções}

Não existem à partida contraindicações para estes fármacos, à exceção da gravidez, tentativa de engravidar e lactação, por ausência de dados. Por uma questão de segurança as mulheres devem esperar um período de 4-6 meses após terminar esta terapêutica até engravidar. Os doentes com patologia vascular grave, toxicodependência, abuso de álcool e doença mental grave foram excluídos dos ensaios, pelo que por enquanto não se recomenda o uso nestes grupos.

\section{Efeitos adversos}

Vidé capítulo 3.3.2.B.2 (tratamento preventivo da EE)

\section{Recomendações para seleção de doentes}

A aprovação dos Amc-CGRP e Amc-rCGRP foi feita para doentes com enxaqueca e com $\geq 4$ dias por mês, o que inclui todos os doentes com enxaqueca crónica. Contudo, existe algum consenso que não são fármacos de primeira linha, sobretudo devido ao custo elevado, o que constitui atualmente o principal obstáculo à sua utilização.

A maioria das Sociedades Internacionais e peri$\operatorname{tos}^{22,51}$ recomendam a sua prescrição em segunda ou terceira linha na EC, ou seja, em doentes que já falharam pelo menos duas terapêuticas prévias (preventivos orais e/ou toxina botulínica). A SPC recomenda que a sua prescrição para a Enxaqueca crónica seja feita em centros terciários (Consultas/Centros de Cefaleias), por peritos, em terceira linha, após falência em dose e tempo adequados (ou efeitos adversos, intolerância ou contraindicação), a pelo menos 3 dos fármacos preventivos (incluindo preferencialmente o topiramato e toxina botulínica). A SPC recomenda ainda que a seleção e a monitorização da resposta a estes fármacos seja documentada através de calendários de crises e medidas simples de impacto.

Os doentes que se encontram medicados com preventivos orais mas com resposta insuficiente, podem manter essa medicação ao iniciar os Amc-CGRP, pois não há risco de interação medicamentosa e podem-se associar, como se verificou nos ensaios e noutros estudos, ${ }^{56}$ mas o objetivo deverá ser a redução ou retirada dos fármacos orais logo que 
se verifique melhoria. Não há estudos sobre o uso concomitante dos Amc-CGRP com a toxina botulínica (pois foi requisito para a inclusão dos doentes em todos os ensaios clínicos), pelo que, por enquanto, não se recomenda de um modo geral esta associação, embora possa ser ponderada em situações particulares. Os Amc-CGRP podem ser prescritos em doentes com EC e abuso medicamentoso, pois também são eficazes nesse grupo.

\section{Recomendações para a manutenção e interrupção}

Como foi mencionado, a resposta terapêutica aos Acm-CGRP e Amc-rCGRP tende a ser rápida com aumento da taxa de respondedores nas três primeiras doses mensais. Assim, recomenda-se que os doentes cumpram pelo menos três doses mensais para se decidir se são ou não respondedores (recomendação grau I). Nos casos de administração trimestral recomenda-se avaliar a resposta ao terceiro mês após a primeira injeção. Não havendo resposta alguma é lícito suspender a medicação. Havendo resposta, que o doente valoriza ainda que apenas subjetiva e parcial, podem-se aguardar mais 3 ou 4 meses e reavaliar a situação.

Ainda não existe evidência suficiente, em estudos de vida real, para compreender o que acontece aos doentes após a suspensão terapêutica dos Acm-CGRP, nomeadamente se se verifica recidiva imediata das crises ou se o benefício se mantem, e por quanto tempo. Enquanto não houver evidência, e dados os custos que o tratamento acarreta, a SPCefaleias recomenda a interrupção do tratamento ao fim de 6 a 12 meses de benefício sustentado (redução $>30 \%$ da frequência das crises, ou passagem a formas de enxaqueca episódica ,mas não muito frequente com $<8$ dias de dor por mês), ou melhoria de parâmetros considerados relevantes para o doente (período suficientemente longo para ir além da esperada flutuação natural que se verifica na EC) e reavaliação periódica do doente durante a suspensão. O espaçamento das administrações poderá levar ao desenvolvimento de anticorpos antifármaco e perda da eficácia, pelo que de acordo com os conhecimentos atuais não se recomenda.

\section{CEFALEIA TIPO TENSÃO Introdução}

A cefaleia tipo tensão (CTT) é a cefaleia primária mais prevalente na população mundial e uma das causas mais frequentes de observação em consulta de Neurologia.' Caracteriza-se habitualmente pela ocorrência de episódios de dor de intensidade ligeira a moderada, de expressão bilateral, não pulsátil (descrita habitualmente como "um peso") e sem outras características distintivas associadas. Embora esta definição (de cefaleia cuja principal característica é não ter característica nenhuma) possa invocar um certo despiciendo conceptual, o impacto pessoal, familiar e social da CTT é enorme, pelo que a sua abordagem terapêutica tem um impacto muito relevante em todas estas esferas. ${ }^{2}$

\section{Diagnóstico}

Os critérios de diagnóstico para a CTT encontram-se discriminados na Classificação Internacional de Cefaleias, versão $3{ }^{2}$ já traduzida para a língua portuguesa. ${ }^{3}$ De uma forma genérica, eles permitem elencar três subtipos de CTT: I) a episódica pouco frequente, em que as queixas de dor têm uma frequência média inferior a I dia por mês; 2) a episódica frequente, em que as queixas se podem distribuir por 1-14 dias por mês, por mais de 3 meses e 3) a crónica, em que existem queixas de dor com uma frequência superior a 15 dias por mês, também por mais de 3 meses. ${ }^{2,3}$ Esta divisão é importante, não só do ponto de vista conceptual e diagnóstico (até mesmo fisiopatológico), mas também em termos terapêuticos. Efetivamente, indivíduos com uma frequência de crises baixa podem beneficiar apenas de tratamento agudo, mas indivíduos com queixas frequentes ou crónicas podem necessitar de terapêutica profilática. E, neste contexto, podendo a CTT crónica fazer invocar outro tipo de diagnósticos diferenciais (como a própria enxaqueca crónica e a cefaleia por utilização excessiva de medicação analgésica), de maior importância se reveste a assertividade do clínico e a respetiva intervenção terapêutica, precisamente no sentido de evitar a iatrogenia e a exposição (desnecessária) a riscos não desprezíveis. ${ }^{2,3}$

\section{Recomendações terapêuticas}

I. O tratamento da CTT pode incluir medidas farmacológicas (grau recomendação I, nível de evidência A) e medidas não farmacológicas (grau de recomendação lla, nível de evidência C). ${ }^{4}$ 
2. As medidas de intervenção farmacológica podem dividir-se em dois tipos fundamentais: no tratamento agudo, dirigido aos episódios de dor, que podem surgir tanto na CTT episódica como na crónica (aqui definindo agudizações deste tipo de cefaleia); e no tratamento profilático, dirigido essencialmente à CTT crónica, mas podendo também ser utilizado na episódica frequente (grau I, nível A). ${ }^{4}$

3. O tratamento agudo pode ser feito com recurso a vários fármacos, pertencentes a duas categorias fundamentais: analgésicos simples, como o paracetamol (1000 mg) e o ácido acetilsalicílico (650$1000 \mathrm{mg}$ ) ou anti-inflamatórios não esteróides (AINEs), como o ibuprofeno (200-800 mg), o naproxeno (250-500 mg), o diclofenac (12,5-25 mg) e o cetoprofeno $(25 \mathrm{mg})$ (grau I, nível A) ${ }^{4-8}$.

4. Não é claro que o paracetamol seja menos efetivo que os restantes fármacos, pelo que se pode privilegiar a sua utilização, atendendo ao seu perfil de segurança, particularmente em populações especiais, como crianças, idosos e grávidas (grau I, nível A). ${ }^{4,7}$

5. Existe evidência que suporta que a associação de cafeína (64-200 mg) a analgésicos simples ou a AINEs potencia o seu efeito., ${ }^{4,-11}$ Todavia, tal também conduz a um incremento de efeitos adversos, com risco de evolução para cefaleia por utilização excessiva de analgésicos, particularmente em pessoas com crises frequentes de CTT. Como tal, recomenda-se que as associações fixas com cafeína sejam apenas consideradas como segunda linha terapêutica, em doentes selecionados, que não respondam à monoterapia (grau lla, nível A). ${ }^{4}$

6. Não se recomenda a utilização de opióides (isoladamente ou em associação a outros analgésicos), de triptanos e de relaxantes musculares no tratamento agudo da CTT (grau III, nível C). ${ }^{4}$

7. Quando o doente recorre a uma unidade de saúde, devido à crise de CTT, pode ponderar-se a utilização de formulações parentéricas (endovenosas ou intramusculares) de clorpromazina, metoclopramida, difenidramina (em associação), metamizol ou cetorolac no seu tratamento, para além dos analgésicos simples ou AINEs previamente citados (grau lla, nível C). ${ }^{4,12}$

8. Em doentes com CTT episódica frequente ou CTT crónica, está indicada a utilização de tratamento profilático (grau I, nível A). ${ }^{4}$
9. A evidência que suporta a escolha do tipo de medicamento profilático a utilizar é limitada, mas favorece a classe farmacológica dos antidepressivos tricíclicos, sendo a amitriptilina ( $10-75 \mathrm{mg} / \mathrm{dia})$ a primeira escolha (grau lla, nível A)., ${ }^{4,13}$

10. Como alternativas à amitriptilina podem ser considerados outros fármacos: I) antidepressivos, como a mirtazapina ( $30 \mathrm{mg} / \mathrm{dia})$, a venlafaxina ( $150 \mathrm{mg} / \mathrm{dia})$, a clomipramina (75- I $50 \mathrm{mg} / \mathrm{dia})$, a maprotilina (75 mg/dia) e a mianserina (30$60 \mathrm{mg} / \mathrm{dia}$ ); 2) anticonvulsivantes, como a gabapentina $(2400 \mathrm{mg} / \mathrm{dia})$ e o topiramato $(25-100$ $\mathrm{mg} / \mathrm{dia}$ ); e 3) relaxantes musculares, como a tizanidina (6-18 mg/dia) (grau lla, nível B)., ${ }^{4}, 13$

II. Quando for possível a identificação de pontos-gatilho para a dor na CTT episódica frequente e na CTT crónica, pode ponderar-se a utilização de injecções de lidocaína nesses mesmos pontos, com vista à redução da frequência da dor (e, associadamente, do consumo de medicamentos analgésicos) (grau lla, nível A). 19,20

12. Não existe evidência que suporte a utilização da toxina onabotulínica tipo A no tratamento da CTT (grau llb nível A). ${ }^{21}$

13. Em todos os doentes com diagnóstico de CTT (episódica ou crónica) podem considerar-se as seguintes medidas terapêuticas não farmacológicas, isoladamente ou em associação: regularização de hábitos alimentares e de sono, terapia cognitivo-comportamental, relaxamento, acupuntura (grau lla, nível C) e biofeedback (grau lla, nível A). ${ }^{4,22}$

14. Não existe evidência suficiente para suportar a eficácia das seguintes estratégias de intervenção não farmacológica na CTT: osteopatia, tração muscular, aplicação de frio ou calor local, manipulação da coluna vertebral, estimulação nervosa elétrica transcutânea (TENS), utilização de ultrassons, laser ou outras estratégias de natureza física para eventual inativação de pontos dolorosos (grau llb, nível A). ${ }^{23-27}$

As Tabelas 4.1, 4.2, 4.3 resumem a informação relacionada com as estratégias terapêuticas com indicação para serem utilizadas no tratamento (agudo e profilático) da CTT. 
Tabela 4.1. Tratamento agudo da CTT

\begin{tabular}{|c|c|c|}
\hline Fármaco (dose) & $\begin{array}{l}\text { Grau de } \\
\text { recomen- } \\
\text { dação }\end{array}$ & $\begin{array}{l}\text { Nível de } \\
\text { evidência }\end{array}$ \\
\hline Paracetamol (1000 mg) & \multirow{6}{*}{ I } & \multirow{6}{*}{ A } \\
\hline $\begin{array}{l}\text { Ácido acetilsalicílico } \\
\text { (650-1000 mg) }\end{array}$ & & \\
\hline Ibuprofeno (200-800 mg) & & \\
\hline Naproxeno (250-500 mg) & & \\
\hline Diclofenac (12.5-25 mg) & & \\
\hline Cetoprofeno (25 mg) & & \\
\hline $\begin{array}{l}\text { Associações com cafeína } \\
(64-200 \text { mg) }\end{array}$ & Ila & A \\
\hline $\begin{array}{l}\text { Formulações parentéricas } \\
\text { de clorpromazina, } \\
\text { metoclopramida, } \\
\text { difenidramina (em } \\
\text { associação), metamizol ou } \\
\text { cetorolac }\end{array}$ & Ila & C \\
\hline
\end{tabular}

Não se recomenda a utilização de opióides (isoladamente ou em associação a outros analgésicos), de triptanos e de relaxantes musculares no tratamento agudo da CTT (IIIC).

Tabela 4.2. Tratamento profilático farmacológico da CTT

\begin{tabular}{|c|c|c|}
\hline Fármaco (dose) & $\begin{array}{l}\text { Grau de } \\
\text { recomen- } \\
\text { dação }\end{array}$ & $\begin{array}{l}\text { Nível de } \\
\text { evidência }\end{array}$ \\
\hline Amitriptilina (10-75 mg) & Ila & A \\
\hline Mirtazapina (30 mg) & \multirow{8}{*}{ Ila } & \multirow{8}{*}{ B } \\
\hline Venlafaxina (150 mg) & & \\
\hline Clomipramina (75-150 mg) & & \\
\hline Maprotilina (75 mg) & & \\
\hline Mianserina (30-60 mg) & & \\
\hline Gabapentina (2400 mg) & & \\
\hline Topiramato (25-100 mg) & & \\
\hline Tizanidina (6-18 mg) & & \\
\hline $\begin{array}{l}\text { Lidocaína (administração } \\
\text { local, em casos } \\
\text { seleccionados) }\end{array}$ & Ila & $A$ \\
\hline Toxina onabotulínica tipo A & $\mathrm{IIb}$ & A \\
\hline
\end{tabular}

Tabela 4.3. Tratamento profilático não farmacológico da CTT

\begin{tabular}{|l|c|c|}
\hline Estratégia de intervenção & $\begin{array}{c}\text { Grau de } \\
\text { recomen- } \\
\text { dação }\end{array}$ & $\begin{array}{c}\text { Nível de } \\
\text { evidência }\end{array}$ \\
\hline $\begin{array}{l}\text { Regularização de hábitos } \\
\text { alimentares e de sono, terapia } \\
\text { cognitivo-comportamental, } \\
\text { relaxamento e acupuntura }\end{array}$ & Ila & $\mathrm{C}$ \\
\hline $\begin{array}{l}\text { Osteopatia, tracção muscular, } \\
\text { aplicação de frio ou calor } \\
\text { local, manipulação da coluna } \\
\text { vertebral, TENS, ultrassons, } \\
\text { laser ou outras estratégias de } \\
\text { natureza física }\end{array}$ & Ilb & $\mathrm{A}$ \\
\hline
\end{tabular}

\section{CEFALEIAS TRIGÉMINO-AUTONÓMICAS}

A distinção entre os vários subtipos de cefaleia trigémino-autonómica é essencial na definição da estratégia terapêutica, uma vez que os fármacos usados não funcionam de forma universal em todos os subtipos. Por outro lado há opções terapêuticas que são particularmente eficazes em cada subtipo.' A modificação do estilo de vida e evicção de desencadeantes faz também parte da gestão destes doentes.

Sendo cefaleias primárias pouco frequentes, existe frequentemente um atraso até ao diagnóstico e é aconselhado fazer sempre investigação de causas secundárias, independentemente da resposta terapêutica.'

\subsection{CEFALEIA EM SALVAS}

A cefaleia em salvas caracteriza-se por dores excruciantes, que ocorrem sobretudo de noite. A sua repetição provoca fragmentação do sono, cansaço, ansiedade, depressão, ideação suicida e conduz ao uso excessivo de analgésicos sem benefício clínico, situação agravada nos surtos prolongados e nos doentes com o subtipo crónico. $^{2}$

$\mathrm{Na}$ abordagem deste subtipo de cefaleia deve ser considerado o número diário de crises, o caráter episódico ou crónico e a relação eficácia/efeitos adversos das várias terapêuticas.

Considerando a intensidade elevada da dor e a disrupção da qualidade de vida que as crises acarretam, o objetivo é o alívio rápido das crises com terapêutica de alívio sintomático mas também reduzir a frequência e intensidade das crises ou atingir a sua supressão.'

Considera-se assim a existência de terapêutica aguda, de transição (profilaxia de curta duração) e profilátical. Adicionalmente importa considerar a abordagem da cefaleia em salvas refratária.

\section{Terapêutica aguda (Tabela 5.I)}

O objetivo da terapêutica aguda é diminuir a intensidade da crise e posteriormente deixar o doente livre de dor, rapidamente. ${ }^{3}$ As opções mais utilizadas são o oxigénio normobárico a $100 \%$ em alto fluxo e os triptanos. ${ }^{1,3,4}$

No oxigénio normobárico a 100\%, a utilização de máscara facial de alto fluxo de não reinalação com reservatório ou máscara facial com válvula anti retorno é mais eficaz que uma máscara facial simples $^{5}$ (grau I, nível de 
evidência B). Adicionalmente a máscara facial simples tem orifícios laterais que se não forem ocluídos não permitem a administração de oxigénio a 100\%. O fluxo inicialmente reportado como eficaz foi $6 \mathrm{~L} / \mathrm{min}$, sendo atualmente recomendado 10 a $15 \mathrm{~L} / \mathrm{min}$ pelo menos durante $20 \mathrm{mi}$ nutos (grau I, nível de evidência $\mathrm{A}$ ) com o indivíduo sentado.' A resposta ocorre entre 15 a 20 minutos, abortando a crise. Os efeitos adversos não são comuns ou graves em indivíduos sem doença respiratória e o maior inconveniente é ser difícil ao doente estar sentado e parado durante a crise. Entre $60 \%$ a $80 \%$ dos doentes respondem a este tratamento. ${ }^{6,7} \mathrm{O}$ oxigénio hiperbárico não é recomendado 8 (grau III, nível de evidência B).

Os triptanos são o tratamento farmacológico mais efetivo para abortar as crises da cefaleia em salvas, com alívio reportado em mais de $80 \%$ dos casos. ${ }^{6}$ O sumatriptano administrado por via subcutânea $(6 \mathrm{mg}$ dose única, não está demonstrado maior efeito de doses superiores numa única administração) é o triptano mais rápido e eficaz, atuando geralmente dentro de 15 minutos após injeção' (grau I, nível de evidência A). Num inquérito a 493 doentes, estes referiram efetividade semelhante entre o oxigénio a $100 \%$ e o sumatriptano subcutâneo. ${ }^{6} \mathrm{O}$ spray nasal de zolmitriptano (doses únicas de 5 e $10 \mathrm{mg}$ ) (grau I, nível de evidência A) e o spray nasal de sumatriptano (dose única de 20 mg) (grau I, nível de evidência B) mostraram-se eficazes 30 minutos após a administração em estudos aleatorizados controlados com placebo. ${ }^{7} \mathrm{O}$ zolmitriptano administrado por via oral (dose única de $10 \mathrm{mg}$ ) é comprovadamente eficaz no tratamento agudo da cefaleia em salvas crónica ou episódica (grau I, nível de evidência $B$ ), mas na via oral o efeito no alívio da dor é mais lento, comparado com o tempo até alívio da dor das administrações subcutânea ou intranasal. ${ }^{7}$ Os efeitos adversos esperados são náuseas, vómitos, parestesias, cansaço, tonturas e sonolência ou efeitos relacionados com via de administração.

Adicionalmente, pode ser considerado a administração nasal de lidocaína a 10\% (grau I, nível de evidência C) ou octreótido subcutâneo' (grau I, nível de evidência C).

Foi também demonstrado que a estimulação não invasiva do nervo vago é um tratamento abortivo eficaz na cefaleia em salvas episódica' (grau I, nível de evidência B), mas não na forma crónica. A estimulação percutânea do gânglio esfenopalatino também é eficaz em abortar as crises na cefaleia em salvas crónica ${ }^{7}$ (grau I, nível de evidência $B$ ).

Não há dados científicos de qualidade para recomendar o uso de dihidroergotamina, ergotamina, somatostatina e corticoesteróides no tratamento abortivo da cefaleia em salvas ${ }^{3}$ (grau III, nível de evidência B).

Tabela 5.1. Terapêutica abortiva das crises de cefaleia em salvas

\begin{tabular}{|c|c|c|c|}
\hline Terapêutica & Dose & Grau de recomendação & Nível de evidência \\
\hline Oxigénio (alto fluxo) ${ }^{1}$ & $100 \%$ a $10-15 \mathrm{~L} / \mathrm{min}$ por máscara facial & । & A \\
\hline Sumatriptano subcutâneo ${ }^{7}$ & $6 \mathrm{mg}$ & । & A \\
\hline Zolmitriptano nasal ${ }^{7}$ & 5 e $10 \mathrm{mg}$ & । & A \\
\hline Sumatriptano nasal ${ }^{7}$ & $20 \mathrm{mg}$ & I & $B$ \\
\hline Zolmitriptano oral ${ }^{7}$ & $10 \mathrm{mg}$ & I & B \\
\hline Octreótido subcutâneo 3 & $100 \mathrm{mcg}$ & I & C \\
\hline Lidocaína nasal ${ }^{3}$ & Solução a $10 \%$ & I & C \\
\hline $\begin{array}{l}\text { Estimulação não invasiva do } \\
\text { nervo vago }{ }^{1} \text { e minimamente } \\
\text { invasiva do gânglio } \\
\text { esfenopalatino }^{7}\end{array}$ & & । & B \\
\hline
\end{tabular}

\section{Terapêutica de transição (Tabela 5.2)}

A terapêutica de transição refere-se à utilização de medicação preventiva que pode ser titulada progressivamente de forma rápida e usada por curtos períodos.
É útil em dois cenários: (I) como preventivo único para doentes com ciclos curtos de cefaleia; e (2) como ponte em doentes com ciclos mais longos de cefaleia enquanto se titula lentamente outros preventivos. ' 
Os principais pilares da terapêutica de transição são os bloqueios do grande nervo occipital ipsilateral (com anestésico local e corticoesteróides) (grau l, nível de evidência B) ou um ciclo de corticoesteróides orais (grau I, nível de evidência $C$ ). Desconhecem-se quais as formulações mais eficazes para os bloqueios ou os melhores protocolos de corticoesteróides orais (doses de prednisona oral entre 30 a $100 \mathrm{mg}$ ). Para os corticoesteróides orais, recomenda-se geralmente uma redução gradual ao longo de 3 semanas, devido ao risco de osteonecrose da anca, especialmente com o uso prolongado.' Não devem ser ultrapassados os 3 ciclos de corticoesteróides por ano.

O frovatriptano e $\circ$ naratriptano foram testados como profiláticos de curta duração, sem resultados sólidos que permitam a sua recomendação9,10 (grau Ilb, nível de evidência $C$ ).

Tabela 5.2. Terapêutica preventiva de transição

\begin{tabular}{|l|l|c|c|}
\hline Terapêutica & Dose & Grau de recomendação & Nível de evidência \\
\hline Prednisona oral ${ }^{4}$ & $30-100 \mathrm{mg}$ & I & C \\
\hline $\begin{array}{l}\text { Bloqueio farmacológico } \\
\text { do grande nervo occipital } \\
\text { ipsilateral }\end{array}$ & & I & B \\
\hline
\end{tabular}

\section{Terapêutica profilática (Tabela 5.3)}

O fármaco de primeira escolha para a prevenção da cefaleia em salvas é o verapamilo' (grau I, nível de evidência A). A dose de manutenção diária total habitual é de $240 \mathrm{mg}$ a $960 \mathrm{mg}$ dividida em 3 doses. ${ }^{4}$ Embora os dados sejam limitados, a formulação de libertação imediata é geralmente preferida. As alterações da condução cardíaca são os efeitos secundários mais graves de altas doses de verapamilo, geralmente relacionadas pelo prolongamento do intervalo PR. Um cronograma de vigilância possível é a realização do ECG antes do início, 10 a 14 dias após cada aumento de dose e a cada 6 meses enquanto mantiver medicação.'

Como medicamentos de segunda linha para cefaleia em salvas incluem-se o carbonato de lítio, topiramato, gabapentina e lamotrigina. $O$ carbonato de lítio é eficaz contra placebo em doses entre 600 e $1500 \mathrm{mg}^{4}$ (grau I, nível de evidência B), mas um estudo revelou que é mais lento e menos eficaz que verapamilo. ${ }^{8}$ Por estes motivos, aliado à possibilidade de toxicidade e janela terapêutica estreita, não deve ser considerada antes de ensaio terapêutico com verapamilo. $O$ topiramato na dose 25 a $200 \mathrm{mg}$ demostrou em estudos pequenos não controlados diminuir a intensidade e frequência de crises (grau I, nível de evidência $C$ ), assim como a ga-

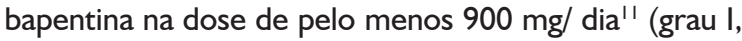
nível de evidência $C$ ).

Demonstrou-se que a melatonina é útil e é frequentemente usada como preventivo em doses que variam entre 3 a $30 \mathrm{mg}$, sendo a dose de $10 \mathrm{mg}$ a mais reco- mendada $^{3}$ (grau I, nível de evidência C).

Igualmente um estudo isolado de pequenas dimensões demonstrou que a varfarina com INR I, 5-I,9 pode ser útil como preventivo ${ }^{8}$ (grau I, nível de evidência C).

As terapêuticas que têm o CGRP como alvo são alternativas interessantes. Serão particularmente úteis se houver resposta subótima ou má tolerabilidade aos restantes fármacos. ${ }^{12}$ Até ao momento apenas 0 galcanezumab mostrou ser eficaz na profilaxia das crises de cefaleia em salvas, mas exclusivamente no subtipo episódico, seja como primeira opção terapêutica, seja em doentes refratários a 2 ou mais preventivos ${ }^{13}$ (grau I, nível de evidência B). No entanto, a agência europeia do medicamento não aprovou a utilização do galcanezumab na cefaleia em salvas.

A toxina onabotulínica tipo A foi estudada em doentes com cefaleia em salvas crónica refratária e adicionada à terapêutica de base. ${ }^{14}$ Foi usado o protocolo PREEMPT com uma aplicação inicial e outra 12 semanas depois, com redução da intensidade, duração e frequência das crises (grau I, nível de evidência C).

Para a cefaleia em salvas episódica, os preventivos devem ser titulados progressivamente no início do ciclo de cefaleia até uma dose eficaz, usando profilaxia de transição, se necessário. Quando o doente está sem cefaleia há cerca 2 semanas e presumivelmente está fora do período de salvas, a medicação preventiva pode ser diminuída e descontinuada.' 
Tabela 5.3. Terapêutica preventiva de longa duração da cefaleia em salvas

\begin{tabular}{|c|c|c|c|}
\hline Terapêutica & Dose & Grau de recomendação & Nível de evidência \\
\hline Verapamilo $^{4}$ & $240-960 \mathrm{mg}$ & । & A \\
\hline Lítio $^{4}$ & $600-1500 \mathrm{mg}$ & । & B \\
\hline Galcanezumab 13 & 300 mg sc/mês & I & B \\
\hline Melatonina ${ }^{3}$ & $10 \mathrm{mg}$ & I & C \\
\hline Topiramato ${ }^{11}$ & 25 a $200 \mathrm{mg}$ & I & C \\
\hline Gabapentina ${ }^{11}$ & $900 \mathrm{mg}$ & I & C \\
\hline Varfarina ${ }^{8}$ & INR 1,5 - 1,9 & 1 & $\mathrm{C}$ \\
\hline Toxina onabotulínica $A^{14}$ & Protocolo PREEMPT & I & C \\
\hline Estimulação invasiva do grande nervo occipital ${ }^{7}$ & & I & C \\
\hline
\end{tabular}

Terapêutica da cefaleia em salvas refratária

Considera-se cefaleia em salvas crónica refratária quando existem pelo menos três crises com impacto na qualidade vida por semana, apesar ter sido feita terapêutica aguda e preventiva, e de terem sido feitos pelo menos três tentativas consecutivas de tratamentos preventivos na dose máxima tolerada, durante um período de tempo considerado suficiente. ${ }^{15}$ Esta definição implica exclusão de causas secundárias ou outras cefaleias primárias. Não há definição consensual para refratariedade no subtipo episódico de cefaleia em salvas.

Admite-se nesta circunstância que os tratamentos mais dispendiosos, menos disponíveis em ambulatório ou invasivos sejam utilizados neste caso. É o caso da lidocaína nasal, octeótrido subcutâneo, estimulação não invasiva do nervo vago' e não invasiva do gânglio esfenopalatino ${ }^{7}$ na terapêutica aguda (grau I, nível de evidência C) e na terapêutica preventiva a toxina onabotulínica tipo $A^{14}$ (grau I, nível de evidência $C$ ) e a estimulação elétrica do grande nervo occipital ${ }^{7}$ (grau I, nível de evidência C).

Embora não esteja autorizado a nível europeu, o galcanezumab seria uma boa opção nos doentes refratários, já que será eficaz em doentes que não tiveram resposta a 2 ou mais preventivos. ${ }^{13}$

A estimulação cerebral profunda não é recomendada, uma vez que não demonstrou eficácia em estudos controlados com estimulação simulada e a técnica suscitou reservas nesta indicação devido a complicações intra-operatórias e pós-operatórias graves e ocasionalmente fatais ${ }^{7,8}$ (grau III, nível de evidência B).

\subsection{CEFALEIA HEMICRÂNIA PAROXÍSTICA (Tabelas 5.4 e 5.5) e HEMICRÂNIA CONTÍNUA} (Tabelas 5.6 e 5.7)

A indometacina é o tratamento de escolha para a cefaleia hemicrânia paroxística (HP) e hemicrânia contínua $(\mathrm{HC})$, considerando-se a resposta positiva à administração deste fármaco critério de diagnóstico. ${ }^{16}$ É utilizada na fase aguda e como tratamento crónico. As doses recomendadas são: adultos de 75 a 325 mg; crianças de 25 a 175 mg.

Recomenda-se uma dose inicial de $25 \mathrm{mg}$ em 3 tomas diárias, com aumento de $25 \mathrm{mg}$ cada 3 a 5 dias até dose máxima. Alguns autores propõem, após um período de estabilização de 3-6 meses, iniciar a redução de $25 \mathrm{mg} \mathrm{em}$ intervalos de 5 a 7 dias até suspensão total do fármaco ou reaparecimento da dor. Se a dor reaparecer aumentar de novo $25 \mathrm{mg}$ cada 2 a 3 dias. É recomendada a associação de um inibidor da bomba de protões para prevenção de efeitos secundários a nível gastrointestinal. No entanto as contraindicações e efeitos secundários da indometacina tornam por vezes necessário recorrer a alternativas.

A indometacina está contraindicada em doentes com insuficiência renal, úlceras gástricas e distúrbios hemorrágicos. Sabe-se que o aparecimento de complicações gastrointestinais e renais é dose dependente e a principal causa de abandono da terapêutica. Outras terapêuticas são referidas na literatura, com graus de eficácia inferiores; a associação destes fármacos permite reduzir a dose de indometacina e, consequentemente, o aparecimento de efeitos secundários. 
Tabela 5.4. Hemicrânia paroxística - tratamento de fase aguda ${ }^{16,17}$

\begin{tabular}{|l|l|c|c|}
\hline Terapêutica & Dose & Grau de recomendação & Nível de evidência \\
\hline Indometacina & $75-325 \mathrm{mg}$ & $\mathrm{I}$ & $\mathrm{C}$ \\
\hline Piroxicam & $20-40 \mathrm{mg}$ & $\mathrm{I}$ & $\mathrm{C}$ \\
\hline Sumatriptano & $6 \mathrm{mg} \mathrm{sc}$ & $\mathrm{I}$ & $\mathrm{C}$ \\
\hline Oxigénio (alto fluxo) & $100 \%$ a $6 \mathrm{~L} / \mathrm{min}$ por máscara facial & $\mathrm{I}$ & $\mathrm{C}$ \\
\hline
\end{tabular}

Tabela 5.5. Hemicrânia paroxística - tratamento prolongado ${ }^{16,17}$

\begin{tabular}{|l|l|c|c|}
\hline Terapêutica & Dose & Grau de recomendação & Nível de evidência \\
\hline Indometacina & $75-325 \mathrm{mg}$ & I & C \\
\hline Verapamilo & $240-960 \mathrm{mg}$ (crianças $-200 \mathrm{mg})$ & । \\
\hline Carbamazepina & $800 \mathrm{mg}$ & I & $\mathrm{C}$ \\
\hline Topiramato & $50-300 \mathrm{mg}$ & I \\
\hline
\end{tabular}

Tabela 5.6. Hemicrânia contínua - tratamento de fase aguda $16,17,18,19$

\begin{tabular}{|l|l|c|c|}
\hline Terapêutica & Dose & Grau de recomendação & Nível de evidência \\
\hline Indometacina & $75-325 \mathrm{mg}$ & $\mathrm{I}$ & $\mathrm{C}$ \\
\hline Piroxicam & $20-40 \mathrm{mg}$ & I & $\mathrm{C}$ \\
\hline Celecoxib & $200-800 \mathrm{mg}$ & $\mathrm{I}$ & $\mathrm{C}$ \\
\hline SONB e GONB & (informação no texto) & I & $\mathrm{C}$ \\
\hline
\end{tabular}

Tabela 5.7. Hemicrânia contínua - tratamento prolongado ${ }^{16,17,18,19}$

\begin{tabular}{|c|c|c|c|}
\hline Terapêutica & Dose & Grau de recomendação & Nível de evidência \\
\hline Indometacina & $75-325 \mathrm{mg}$ & I & C \\
\hline Verapamilo & $120-240 \mathrm{mg}$ & I & C \\
\hline Gabapentina & $600-3600 \mathrm{mg}$ & I & C \\
\hline Topiramato & $50-300 \mathrm{mg}$ & I & C \\
\hline Piroxicam & $20-40 \mathrm{mg}$ & I & C \\
\hline Celecoxib & $200-800 \mathrm{mg}$ & I & $\mathrm{C}$ \\
\hline Melatonina & $3-30 \mathrm{mg}$ & I & $C$ \\
\hline Toxina onabotulínica A & $100-185 U$ & I & C \\
\hline SONB e GONB & (informação no texto) & I & C \\
\hline
\end{tabular}

\section{Bloqueio no nervo supraorbitário (SONB)}

- 0,5 - I,5 mg/mL com I2,5 mg adrenalina; ou

- 2 cc solução de bupivacaína a 0,5\% e mepivacaína a $2 \%$ a $1: 1$

\section{Bloqueio do grande nervo occipital (GONB)}

- 9 cc de lidocaína a 1\% com 40 mg de triamcinolona; ou

- 2 cc de bupivacaína a 0,5\% e mepivacaína a $2 \%$ a I:I 
5.3 SUNCT (short-lasting unilateral neuralgiform headache attacks with conjunctival injection and tearing) / SUNA (short-lasting unilateral neuralgiform headache attacks with autonomic symptoms) (Tabela 5.8 e 5.9 )

A abordagem terapêutica destas entidades é sobreponível e o tratamento da crise é na maioria das situações de pouca utilidade, considerando a curta duração dos episódios. Relativamente à prevenção vários fármacos têm sido utilizados ao longo do tempo, com resul- tados referidos em pequenas séries e casos clínicos. ${ }^{16,17}$

A lidocaína via endovenosa na fase aguda e a lamotrigina como prevenção parecem ser as terapêuticas mais eficazes. É ainda considerada uma terapêutica "de transição", durante 7-10 dias até que comece a ter efeito a terapêutica de manutenção. A perfusão de lidocaína exige monitorização cardíaca.

Nos casos de falência da terapêutica médica a abordagem cirúrgica tem sido tentada, sendo as opções semelhantes às da nevralgia do trigémeo. ${ }^{20}$

Tabela 5.8. Fase aguda / transição (SUNCT e SUNA)

\begin{tabular}{|l|l|c|c|}
\hline Terapêutica & Dose & Grau de recomendação & Nível de evidência \\
\hline Lidocaína & $1-3,5 \mathrm{mg} / \mathrm{kg} / \mathrm{hora} \mathrm{ev}$ & $\mathrm{I}$ & $\mathrm{C}$ \\
\hline Prednisolona & $20-100 \mathrm{mg}$ & $\mathrm{I}$ & $\mathrm{C}$ \\
\hline Metilprednisolona & $16-1000 \mathrm{mg} \mathrm{ev}$ & $\mathrm{I}$ \\
\hline $\begin{array}{l}\text { Bloqueio grande } \\
\text { nervo occipital }\end{array}$ & Metilprednisolona $80 \mathrm{mg} /$ lidocaína $2 \% 2 \mathrm{~mL}$ & $\mathrm{I}$ & $\mathrm{C}$ \\
\hline
\end{tabular}

Tabela 5.9. Tratamento prolongado (SUNCT e SUNA)

\begin{tabular}{|l|l|c|c|}
\hline Terapêutica & Dose & Grau de recomendação & Nível de evidência \\
\hline Lamotrigina & $50-900 \mathrm{mg}$ & $\mathrm{I}$ & $\mathrm{C}$ \\
\hline Oxcarbazepina & $100-2000 \mathrm{mg}$ & $\mathrm{I}$ & $\mathrm{C}$ \\
\hline Topiramato & $40-400 \mathrm{mg}$ & $\mathrm{I}$ \\
\hline Duloxetina & $30-120 \mathrm{mg}$ & $\mathrm{I}$ & $\mathrm{C}$ \\
\hline Carbamazepina & $100-2000 \mathrm{mg}$ & $\mathrm{I}$ & $\mathrm{C}$ \\
\hline Gabapentina & $300-3600 \mathrm{mg}$ & $\mathrm{I}$ & $\mathrm{C}$ \\
\hline Pregabalina & $<600 \mathrm{mg}$ & $\mathrm{I}$ & $\mathrm{C}$ \\
\hline
\end{tabular}

A abordagem cirúrgica, nos casos refratários à terapêutica médica inclui a descompressão microvascular do nervo trigémeo, a estimulação do nervo occipital e a estimulação cerebral profunda (VTA) $4 \mathrm{mV}$ com frequência de $185 \mathrm{~Hz}{ }^{20}$

\section{OUTRAS CEFALEIAS PRIMÁRIAS}

Neste capítulo constam cefaleias primárias raras que são sempre um diagnóstico de exclusão, devendo ser consideradas cefaleias secundárias até prova em contrário. Na sua maioria apresentam-se como crises álgicas de muito curta duração pelo que nem sempre é necessária terapêutica farmacológica.' Em casos sele- cionados, a terapêutica farmacológica é instituída, sendo as recomendações aqui referidas baseadas em estudos prospetivos e observacionais, carecendo por isso de evidência científica robusta.

\subsection{CEFALEIA PRIMÁRIA DA TOSSE}

A terapêutica farmacológica raramente é necessária. Se as crises forem muito frequentes e afetarem negativamente a qualidade de vida, pode iniciar-se a indometacina, ${ }^{2}$ na dose de 50 a 100 mg id (grau de recomendação Ila, nível de evidência $C$ ). É prudente a utilização concomitante de um protetor gástrico. ${ }^{3}$ Em alternativa, existem casos respondedores à acetazolamida ${ }^{4}$ na dose 125 mg tid a 2000 mg id (grau de recomendação Ilb, nível de evidência $C$ ) e a punções lombares evacuadoras ${ }^{5}$ 
com remoção de 40cc de LCR (grau de recomendação Ilb, nível de evidência $C$ ).

\subsection{CEFALEIA PRIMÁRIA DO EXERCÍCIO}

Este tipo de cefaleia é habitualmente recorrente pelo que $o$ doente consegue identificar a atividade desencadeante. A maioria das vezes a evicção de tal atividade física é suficiente para o alívio sintomá tico. No entanto, o exercício físico regular faz parte de um estilo de vida saudável pelo que pode equacionar-se a sua manutenção e instituir tratamento farmacológico. A cefaleia primária do exercício é tipicamente responsiva à indometacina (grau de recomendação Ila, nível de evidência C). Este fármaco pode ser utilizado previamente ao desempenho da atividade física, ou de forma profilática na dose 25 a 150 mg id. 6,7 Quando a profilaxia com indometacina não for tolerada, pode ser utilizado o propranolol na dose I a $2 \mathrm{mg} / \mathrm{kg}^{8}$ (grau de recomendação Ilb, nível de evidência C). Existe ainda a publicação de alguns casos respondedores à flunarizina ${ }^{7}$ (grau de recomendação Ilb, nível de evidência $C$ ).

\subsection{CEFALEIA PRIMÁRIA ASSOCIADA À AC- TIVIDADE SEXUAL}

Pode ser utilizada a indometacina na dose de 25 a 50 mg, 30-60 minutos antes da atividade sexual (grau de recomendação llb, nível de evidência $\mathrm{C}$ ). Se os episódios forem muito frequentes pode equacionar-se a profilaxia com beta-bloqueantes: propranolol $60-240 \mathrm{mg}$ id, metoprolol 50-200 mg id ou bisoprolol 5mg id ${ }^{9}$ (grau de recomendação Ilb, nível de evidência $\mathrm{C}$ ).

\subsection{CEFALEIA EXPLOSIVA PRIMÁRIA}

Todos os fármacos potencialmente vasoconstritores deverão ser suspensos (grau de recomendação lla, nível de evidência $C$ ). $O$ tratamento profilático faz-se com a nimodipina, na dose de 30 a 60 mg qid, durante 2 a 3 me$\operatorname{ses}^{8,10}$ (grau de recomendação llb, nível de evidência C).

\subsection{CEFALEIA POR ESTÍMULO FRIO}

A cefaleia não ocorre se se conseguir a evicção do desencadeante, quer seja a inalação ou a ingestão de um estímulo frio (grau de recomendação Ilb, nível de evidência C). Quando não é possível, recomenda-se a ingestão lenta dos alimentos frios.'

\subsection{CEFALEIA POR PRESSÃO EXTERNA}

A cefaleia por pressão externa raramente necessita tratamento farmacológico, resolvendo habitualmente nos 60 minutos após o alívio da compressão externa. ${ }^{11,12}$ Como prevenção, os desencadeantes devem ser evitados (grau de recomendação Ilb, nível de evidência C). Caso não seja possível, deverá ser escolhida a opção mais confortável entre os vários estilos, tamanhos e materiais, garantindo um tamanho apropriado e um correto posicionamento. Durante o uso, é benéfica a remoção frequente do desencadeante de modo a aliviar temporariamente a compressão. ${ }^{12}$

\subsection{CEFALEIA PRIMÁRIA EM GUINADA}

Dada a variabilidade na frequência e intensidade desta cefaleia, o tratamento farmacológico em muitos casos não é necessário, devendo ser explicada a sua benignidade. $O$ tratamento preventivo deve ser considerado em doentes com crises frequentes, ou quando interfere nas atividades diárias. $\bigcirc$ tratamento de primeira linha é a indometacina (grau de recomendação lla, nível de evidência (), em doses entre os 75 e os $150 \mathrm{mg}$ por dia. ${ }^{13-15} \mathrm{Em}$ caso de ineficácia, contraindicação ou efeitos secundários que limitem o uso da indometacina, podem ser considerados fármacos que demonstraram benefício em pequenas series de doentes e relatos de casos clínicos como inibidores da COX-2 (ex. celecoxib 100 $\mathrm{mg}$ bid ou etoricoxib $60 \mathrm{mg}$ id), ${ }^{16,17}$ gabapentina (400 mg bid), ${ }^{18}$ melatonina (3-2l mg id), ${ }^{19}$ nifedipina (90 mg id) ${ }^{20}$ ou toxina botulínica ${ }^{21}$ (grau de recomendação lla, nível de evidência $C$ ).

\subsection{CEFALEIA NUMULAR}

Como tratamento sintomático podem ser utilizados analgésicos comuns (grau de recomendação lla, nível de evidência C), com benefício reportado em mais de $60 \%$ dos doentes. ${ }^{22} \mathrm{Em}$ casos de cefaleia persistente, dor de intensidade grave ou ausência de alívio com analgesia, está indicado o tratamento preventivo ${ }^{22,23} \mathrm{~A}$ gabapentina (600-1800 mg/dia) é o fármaco mais utilizado na literatura (grau de recomendação Ila, nível de evidência C), com alívio pelo menos parcial em mais de $60 \%$ dos doentes, seguindo-se os antidepressivos tricíclicos (grau de recomendação lla, nível de evidência C), com alívio pelo menos parcial em cerca de $45 \%$ dos doentes. ${ }^{22} \mathrm{Pe}$ quenas séries de casos reportam eficácia do tratamento com toxina botulínica (grau de recomendação lla, nível 
de evidência $C$ ), incluindo doentes com cefaleia numular persistente e refractária. ${ }^{22,24-26}$ Casos isolados reportam ainda benefício com carbamazepina, ${ }^{26,27}$ ciclobenzapri$\mathrm{na}^{28}$ e estimulação nervosa transcutânea ${ }^{29}$ (grau de recomendação Ila, nível de evidência C). Os anestésicos locais apresentam baixa eficácia nesta cefaleia (grau de recomendação Ilb, nível de evidência C). ${ }^{22,30}$

\subsection{CEFALEIA HÍPNICA}

O tratamento sintomático de primeira linha é a cafeína, com a toma de uma chávena de café ao acordar com a dor, ou, em alternativa, analgésicos com cafeína (grau de recomendação lla, nível de evidência C). Os triptanos revelaram eficácia em casos isolados (grau de recomendação Ila, nível de evidência $C$ ), sendo os AINE, opioides, oxigénio e paracetamol geralmente pouco eficazes (grau de recomendação Ilb, nível de evidência C). ${ }^{31,32}$ Em doentes com crises muito frequentes deve ser privilegiado o tratamento preventivo, para evitar o uso excessivo de medicação sintomática e os seus efeitos adversos.

A cafeína é também eficaz como tratamento preventivo (grau de recomendação lla, nível de evidência C), com a toma de pelo menos uma chávena de café antes de deitar (40 a 60 mg/dia). Apesar do receio de problemas de sono, este efeito secundário verifica-se com menor frequência que o esperado. ${ }^{32} \mathrm{O}$ lítio, em doses entre 150 a 600 mg/dia é um preventivo eficaz (grau de recomendação lla, nível de evidência C), no entanto deve ser usado com precaução na população idosa tendo em conta o seu perfil de efeitos adversos. ${ }^{31-33}$ Outra alternativa é a indometacina (25-150 mg/dia) que revelou eficácia em pequenas séries de doentes (grau de recomendação Ila, nível de evidência $\mathrm{C}$ ), com benefício em cerca de $50 \%$ dos casos, especialmente se cefaleia unilateral ou sintomas autonómicos acompanhantes. ${ }^{34}$ $\mathrm{Na}$ cefaleia hípnica, o tratamento preventivo deve ser mantido durante 3 a 6 meses, antes de ser tentada a sua descontinuação.

\subsection{CEFALEIA PERSISTENTE DIÁRIA DESDE O INÍCIO}

A cefaleia persistente diária desde o início tem uma história natural incerta, sendo variável a sua duração e resposta aos tratamentos. Apesar de alguns casos serem autolimitados com remissão em alguns meses, muitos doentes evoluem para uma cefaleia persistente duran- te décadas a anos sem resposta a qualquer tratamento agudo ou preventivo. ${ }^{35}$

Em termos de tratamento agudo os triptanos demonstraram alívio pelo menos parcial em até $1 / 3$ dos doentes, mesmo quando a dor não apresenta características migranosas (grau de recomendação lla, nível de evidência C). ${ }^{36} \mathrm{~A}$ maioria dos doentes apresenta uso excessivo de medicação analgésica, no entanto a suspensão dos analgésicos geralmente não se traduz em alívio da dor. ${ }^{35,37}$

Pequenas séries de doentes reportam alguns casos com benefício de tratamento preventivo com topiramato, gabapentina, valproato, amitriptlina, nortriptilina, propranolol, clonazepam, mexiletina ou toxina botulínica (grau de recomendação Ila, nível de evidência C). ${ }^{35,36,38-42}$ Os bloqueios de nervo periférico demonstraram alívio apenas transitório da cefaleia ${ }^{43}$ (grau de recomendação Ilb, nível de evidência $\mathrm{C}$ ). Em doentes com desencadeante infecioso, pequenas séries descrevem eficácia de montelucaste, doxiciclina ou metilprednisolona intravenosa ${ }^{42,43}$ (grau de recomendação lla, nível de evidência $\mathrm{C}$ ).

$\mathrm{Na}$ ausência de guidelines ou estudos randomizados que orientem o tratamento, alguns autores recomendam guiar o tratamento pelo fenótipo da cefaleia, sendo habitualmente tentadas várias combinações de fármacos nesta cefaleia de difícil controlo. ${ }^{37,43}$

\section{NEVRALGIA DO TRIGÉMEO}

\section{Introdução}

A nevralgia do trigémeo (NT) é uma entidade clínica caracterizada por episódios de dor muito intensa, de muito curta duração, tipo choque elétrico (com início e fim abruptos), recorrendo com elevada frequência, habitualmente unilateral e localizada ao território inervado por uma ou mais divisões (nervos oftálmico, maxilar e mandibular) do nervo trigémeo ( $5^{\circ}$ par craniano). Estes episódios podem ser despertados por alguns estímulos, habitualmente considerados inócuos (mastigar ou lavar os dentes, por exemplo).

A incidência anual da NT é, de acordo com a literatura, de 4-13 casos por 100000 habitantes, ${ }^{1,2}$. Apesar de esta incidência não ser muito elevada, a NT é a mais frequente das nevralgias, na população adulta (podendo também acometer crianças e adolescentes ${ }^{3}$ ), sendo 
que essa mesma incidência aumenta gradualmente com a idade.

\section{Diagnóstico}

Os critérios de diagnóstico para a NT encontram-se explanados no capítulo 13 da Classificação Internacional de Cefaleias - versão 3 (ICHD-3). ${ }^{4}$ Poder-se-á afirmar o diagnóstico quando estiverem presentes paroxismos recorrentes de dor facial unilateral na distribuição anatómica de um ou mais ramos do nervo trigémeo (sem irradiação para outros territórios) e preenchendo os critérios $B$ e $C$ dos seguintes ${ }^{4}$ :

A. A dor tem todas as seguintes características:

I. Duração de uma fração de segundos a 2 minutos;

2. Intensidade grave;

3. Tipo choque elétrico, fisgada, facada ou guinada.

B. É precipitada por estímulos inócuos dentro da distribuição anatómica do nervo trigémeo afetado.

C. Não é melhor explicada por outro diagnóstico da ICHD-3.

A NT pode ser categorizada em 3 tipos distintos: I) a NT clássica, que se presume resultar de compressão vascular sobre o nervo trigémeo (habitualmente por um vaso arterial, como é o caso da artéria cerebelosa superior); 2) a NT secundária, em que o quadro doloroso é sintomático de outra patologia envolvendo o nervo trigémeo (como um tumor) ou a sua origem real no tronco cerebral (como uma lesão desmielinizante de esclerose múltipla); e 3) a NT idiopática, quando não é possível invocar qualquer explicação para a sua etiologia. Estes são aspetos práticos com algum relevo, quando se equacionam as estratégias de intervenção terapêutica.

\section{Recomendações terapêuticas}

\section{Terapêutica farmacológica de base (preventiva)}

I. O tratamento da NT deve iniciar-se por uma abordagem médica/farmacológica (grau de recomendação I, nível A).

2. Existe evidência que suporta que, nos casos de NT clássica ou idiopática, a carbamazepina (2001200 mg/dia) deve ser o fármaco de primeira escolha, não existindo contraindicações ou riscos de interação medicamentosa com outros fármacos em uso (grau I, nível A). . $^{5-11}$

3. A oxcarbazepina (600-1800 mg/dia) constitui uma excelente alternativa à carbamazepina, sendo igualmente eficaz e com melhor perfil de seguran- ça/tolerabilidade (grau I, nível B). ${ }^{11-14}$

4. Fármacos como o baclofeno $(40-80 \mathrm{mg} / \mathrm{dia})^{15}$ e a lamotrigina $(400 \mathrm{mg} / \mathrm{dia}$, isoladamente ou em associação a um dos fármacos de primeira linha) ${ }^{16}$ podem ser também utilizados no tratamento da NT clássica ou idiopática, embora a evidência que suporte a sua utilização seja pouco robusta (grau Ila, nível C).9-1।

5. Não se recomenda a utilização de fármacos como o ácido valpróico (grau Ilb, nível C), a gabapentina (grau Ilb, nível C), a pregabalina (grau Ilb, nível C), o clonazepam (grau Ilb, nível C) e o topiramato (grau llb, nível C) no tratamento específico da NT, por não existir evidência que suporte a sua eficácia e a sua segurança nesta indicação precisa. ${ }^{10,11,17}$

6. O tratamento farmacológico da NT secundária obedece aos mesmos princípios, embora deva ser complementada com o tratamento dirigido à causa subjacente (grau I, nível A).9-1I

7. Um doente que não responda aos tratamentos farmacológicos supracitados ou que não consiga alcançar doses consideradas eficazes devido a efeitos adversos deve ser considerado como tendo uma NT refratária e, por esse motivo, deve ser referenciado a um centro especializado (grau I, nível A). ${ }^{18}$

8. Existe evidência que suporta a utilização de toxina botulínica de tipo $\mathbf{A}$ no tratamento da NT refratária, devendo tal intervenção ser realizada em centros com experiência na manipulação deste fármaco (grau I, nível B). ${ }^{19,20}$

\section{Terapêutica hospitalar da agudização (crise)}

I. Em meio hospitalar e apenas em situações de urgência, podem ser utilizadas formulações endovenosas de lidocaína ou de fenitoína (não havendo fosfenitoína disponível), na abordagem da NT (grau lla, nível C)."

2. A lidocaína poder-se-á utilizar em doses de $5 \mathrm{mg} /$ kg de peso, diluídos em $250 \mathrm{~mL}$ de dextrose a $5 \%$, perfundindo-se a um ritmo de $\mathrm{I} \mathrm{mg} /$ minuto nas primeiras 4 horas e de $2 \mathrm{mg} /$ minuto a partir daí. ${ }^{21,22}$

3. A fenitoína usa-se em perfusões de $10-20 \mathrm{mg} / \mathrm{kg}$ de peso (máximo de $1000 \mathrm{mg}$ ), sendo que o tempo de infusão pode variar entre 30 e 60 minutos, recomendando-se monitorização cardíaca e da tensão arterial durante o procedimento. ${ }^{23}$

4. Em doentes com contraindicação para os fármacos 
supracitados, poderá ser ponderada a utilização das formulações endovenosas de levetiracetam ( $1000-4000$ mg/dia) ou lacosamida (200 mg/dia), embora a evidência que suporte a sua utilização seja muito escassa (grau Ilb, nível C). ${ }^{24-27}$

\section{Terapêutica cirúrgica}

I. Doentes com NT refratária à terapêutica médica são candidatos a tratamento cirúrgico (grau I,nível B). ${ }^{9-11,28}$

2. Podem ser utilizadas várias técnicas para abordagem cirúrgica de uma NT, mas a evidência que suporta a escolha entre cada uma delas é limitada e muito dependente da experiência do neurocirurgião que a executa (grau I, nível C).

3. A descompressão microvascular, os procedimentos percutâneos sobre o gânglio trigeminal (nomeadamente a rizotomia) e a radiocirurgia com gamma-knife parecem ser eficazes no tratamento da NT (grau I, nível C). ${ }^{9-1 I}$

4. Não existe evidência que suporte a utilização de bloqueios ou neurectomias periféricas no tratamento da NT, pelo que a sua utilização não se recomenda (grau Ilb, nível C). ${ }^{29}$

A Tabela 7.1 resume toda esta informação.

Tabela 7.1. Terapêutica da nevralgia do trigémeo

\begin{tabular}{|c|c|}
\hline Fármaco & Evidência \\
\hline \multicolumn{2}{|l|}{ Terapêutica médica preventiva } \\
\hline Carbamazepina (200-1200 mg/dia) & Grau I, nível A \\
\hline Oxcarbazepina (600-1800 mg/dia) & Grau I, nível B \\
\hline Baclofeno (40-80 mg/dia) & \multirow{2}{*}{ Grau lla, nível C } \\
\hline Lamotrigina (400 mg/dia) & \\
\hline Toxina botulínica de tipo A & Grau I, nível B \\
\hline Fármaco & Evidência \\
\hline \multicolumn{2}{|l|}{ Terapêutica médica da agudização } \\
\hline Fenitoína (10-20 mg/kg) & \multirow{2}{*}{ Grau lla, nível C } \\
\hline Lidocaína (5 mg/kg) & \\
\hline Levetiracetam (1000-4000 mg/dia) & \multirow{2}{*}{ Grau Ilb, nível C } \\
\hline Lacosamida (200 mg/dia) & \\
\hline Procedimento & Evidência \\
\hline \multicolumn{2}{|l|}{ Terapêutica cirúrgica } \\
\hline Descompressão microvascular & \multirow{3}{*}{ Grau I, nível C } \\
\hline Procedimentos percutâneos sobre o gânglio trigeminal & \\
\hline Radiocirurgia com gamma-knife & \\
\hline
\end{tabular}

\section{CEFALEIA POR USO EXCESSIVO DE MEDICAMENTOS}

\section{INTRODUÇÃO}

A cefaleia por uso excessivo de medicamentos é classificada como uma cefaleia secundária, ou seja, é considerado que ocorre em consequência de outra situação reconhecidamente capaz de causar cefaleias. Este nexo de casualidade é definido de pela relação temporal, significando que a cefaleia tem que ocorrer ou agravar de forma relevante em paralelo com a situação potencialmente causadora (neste caso, o uso excessivo de medicamentos) ou tem que melhorar significativamente em paralelo com a melhoria da presumida patologia causal. ${ }^{1,2}$ 
No caso particular da cefaleia por uso excessivo de medicamentos, o contexto em que ocorre mais frequentemente é em doentes com cefaleias primárias preexistentes. A situação mais habitual é que as cefaleias prévias se tornem crónicas em estreita relação temporal com a patologia causal (neste caso, o uso excessivo de medicamentos) - estes doentes terão, formalmente, ambos os diagnósticos - da sua cefaleia primária e do uso excessivo de medicação, uma cefaleia secundária. ${ }^{1,2}$

$\mathrm{Na}$ versão anterior da classificação das cefaleias ${ }^{3,4}$ era critério de diagnóstico a necessidade destas cefaleias desaparecerem ou reassumirem o seu padrão prévio após dois meses de interrupção do uso excessivo de medicação. Este critério foi retirado por motivos pragmáticos, pois impedia o diagnóstico até ao efetivo tratamento (que nem sempre é bem-sucedido), mas indica que a terapêutica mais eficiente nesta situação é a suspensão da utilização excessiva de medicamentos.

\section{DIAGNÓSTICO E EPIDEMIOLOGIA}

A cefaleia por uso excessivo de medicamentos está no capítulo 8 da Classificação Internacional das Cefaleias $^{1,2}$ - cefaleias atribuídas a uma substância ou à sua privação - sendo definida como ocorrendo em 15 ou mais dias por mês (ou seja, é crónica), num doente com cefaleia primária preexistente e desenvolvendo-se em consequência do uso excessivo regular por mais de 3 meses de medicação aguda ou sintomática para as cefaleias. É subclassificada de acordo com a substância utilizada em excesso - ergotamina, triptanos, analgésicos não opióides, opióides, associações de analgésicos e medicamentos de classes farmacológicas múltiplas sendo o critério de uso excessivo a utilização de 10 ou mais dias por mês do fármaco implicado para a maioria das substâncias ou 15 ou mais dias por mês no caso dos analgésicos não opióides (incluindo paracetamol/ acetomifeno, anti-inflamatórios não esteroides (AINEs), ácido acetilsalicílico e outros analgésico não opióides). ${ }^{1,2}$ Num estudo, foi avaliada a duração média crítica de uso excessivo de medicação para desenvolver cefaleia crónica para cada substância, verificando-se que era mais curta para os triptanos ( 1,7 anos, em média), depois para os compostos ergotamínicos (2,7 anos) e finalmente para os analgésicos (4,8 anos). ${ }^{5}$

As definições de tempo de exposição e dose necessária para estabelecimento do diagnóstico de acordo com a Classificação Internacional são baseados em opinião de especialistas (nível de evidência C) no entanto a utilização desta classificação na prática clínica e na investigação é recomendada (grau de recomendação I).

Esta entidade tem uma enorme relevância clínica dada a sua prevalência. Em estudos populacionais os dados de prevalência são muito variáveis, pois dependem do método, local, população (jovens, adultos, idosos), da data de realização do estudo e da definiçãa utilizada. Nos estudos mais recentes, que utilizaram a segunda versão da Classificação Internacional, ${ }^{3,4}$ a sua prevalência varia de 0,5\% (Coreia) a 7,2\% (Rússia), dependendo do país. ${ }^{6}$ Em contexto clínico, estima-se que cerca de $6 \%$ das consultas generalistas e $9 \%$ das consultas de neurologia sejam devidas a esta situação ${ }^{7}$; em centros de referência de cefaleias a frequência desta entidade varia entre $30 \%$ na Europa até $50 \%$ nos Estados Unidos. ${ }^{8}$

É uma entidade mais frequente em adultos dos 40 aos 50 anos, na maioria dos estudos há um predomínio de género - o feminino. ${ }^{6}$ É mais frequente ocorrer em indivíduos com enxaqueca (65\%) ou cefaleias de tensão (27\%) prévias, ${ }^{5}$ aumentando o risco da sua ocorrência nos indivíduos com obesidade e síndrome metabólico (OR 5,3), ingestão regular de sedativos ou tranquilizantes (OR 5,2), com ansiedade e/ou depressão comórbidas (OR 4,7), com inatividade (exercício $<3$ horas por semana, OR 2,7), baixo nível educacional (OR I,9), com doença músculo-esquelética (OR I,9), tabagismo (OR I,8) e doença gastrointestinal (OR I,6) associada. ${ }^{9}$

É rara a ocorrência desta entidade em indivíduos que utilizem analgésicos diariamente para outras patologias (em doença reumatológica ou noutras causas de dor crónica), ${ }^{10,11}$ ocorrendo sobretudo em indivíduos que, concomitantemente, sofram de cefaleias primárias (OR I3,I) ou enxaqueca (OR 6,8) prévia à utilização excessiva de medicação. " Mesmo a utilização regular de opiáceos com fins não analgésicos em doentes com enxaqueca pode induzir a ocorrência de cefaleias crónicas, ${ }^{12}$ suportando a teoria que a probabilidade de ocorrência desta entidade depende sobretudo da biologia do indivíduo que utiliza excessivamente analgésicos.

\section{RECOMENDAÇÕES TERAPÊUTICAS}

A atitude terapêutica formal para controle das cefaleias por uso excessivo de analgésicos é a suspensão do uso excessivo de analgésicos, também designada por destoxificação. Este processo frequentemente condiciona uma síndrome de abstinência, ${ }^{13}$ caracterizado por 
agravamento das cefaleias, náuseas, vómitos, hipotensão / reação vagal, taquicardia, perturbações do sono, ansiedade, inquietação e irritabilidade, que habitualmente persiste entre 2 a 10 dias mas pode durar até 4 semanas, dependendo do fármaco a suspender. Habitualmente a sua duração é mais curta nos indivíduos que utilizam excessivamente triptanos - em média 4, I dias - do que os que utilizam ergotamínicos (6,7 dias) ou AINEs (9,5 dias, em média $)^{14}$. A destoxificação resulta em elevadas taxas de remissão - de $66 \%$ a $100 \%$ aos 6 meses e $60 \%$ a $83 \%$ após I ano de suspensão, mas igualmente elevadas taxas de recaída, cerca de $17 \%$ a $43 \%$ no primeiro ano e até $24 \%$ a $45 \%$ no quarto ano, ${ }^{15}$ pelo que uma das estratégias terapêuticas relevantes adicionais é a prevenção da recorrência.

Em resumo, os objetivos do tratamento são ${ }^{16}$ :

I. Suspensão da utilização excessiva de medicação ou destoxificação

2. Tratamento da síndrome de abstinência

3. Tratamento da cefaleia por utilização excessiva de medicação

4. Prevenção da recorrência

\section{Suspensão da utilização excessiva de medi- cação ou destoxificação}

- A educação sobre a patologia e o aconselhamento de suspensão da medicação utilizada em excesso são eficientes na redução da frequência de ingestão de medicação aguda e na redução da frequência das cefaleias 9 , 13,16,17 - recomendação grau I, nível B - e devem ser oferecidas a todos os doentes ${ }^{9,13,18}$ até porque existe evidência de toxicidade sistémica dos fármacos utilizados em excesso ${ }^{15}$ (boa prática clínica).

- A suspensão da utilização excessiva de medicação deve ser efetuada como terapêutica para a cefaleia por utilização excessiva de medicação, com o objetivo de diminuir a frequência das cefaleias ${ }^{13,19}$ (recomendação grau I, nível B) e de melhorar a resposta da cefaleia primária inicial à terapêutica profilática ${ }^{20}$ - recomendação grau II, nível C.

- A suspensão abrupta da utilização excessiva de medicação efetuada isoladamente durante 2 meses é eficiente em retomar o padrão de enxaqueca episódi$\mathrm{ca}^{15,21}$ - recomendação grau lla, nível de evidência $C$.

- A suspensão da utilização excessiva de medicação ou destoxificação pode ser efetuada em regime de internamento ou de ambulatório com a mesma taxa de eficácia ${ }^{13,17,19}$ - recomendação grau I, nível A. 13,17,19 Pode-se considerar a destoxificação em regime de internamento em casos de elevada complexidade, definidos como apresentando doença médica concomitante significativa ou diagnóstico concomitante de perturbação do humor, da ansiedade, abuso de substâncias ou perturbação do comportamento alimentar ou utilização diária de múltiplas doses de várias substâncias analgésicas ou problemas sociais ou ambientais relevantes ou história de recaída após procedimento de destoxificação prévio ${ }^{22}$ - recomendação grau II, nível B.

- A suspensão da utilização excessiva de medicação pode ser abrupta ou progressiva (ou seja, reduzida sucessivamente em $10 \%$ a $20 \%$ por semana), sendo a maioria dos especialistas mais favorável à suspensão abrupta, dado que o sofrimento relacionado com a síndrome de abstinência é contido em menos tempo, abreviando a melhoria clínica e facilitando a mudança de comportamento do doente $^{16,23}$ - recomendação grau Ilb, nível C. Pode-se considerar a descontinuação progressiva nos casos de utilização excessiva de barbitúricos, opióides ou benzodiazepinas, ${ }^{23}$ dado o risco acrescido de sintomatologia de abstinência mais tardia nos casos de fármacos com maiores semividas (como barbitúricos e benzodiazepinas) e mais complexas, tal como a disautonomia, alterações do humor, tremor, hiperreflexia, síndrome confusional, alucinações e convulsões - recomendação grau Ilb, nível C.

- A suspensão abrupta da utilização excessiva de medicação efetuada de forma absoluta é mais eficiente em reverter a enxaqueca crónica para episódica e suspender a utilização excessiva de medicação se não for permitida a utilização de nenhum analgésico nos 2 meses após a suspensão, quando comparado com a permissão de utilização de 2 dias de medicação aguda por semana nesse mesmo período ${ }^{21}$ recomendação grau II, nível de evidência C.

\section{Terapêutica da síndrome de abstinência}

- A síndrome de abstinência de analgésicos e/ou triptanos após suspensão abrupta da utilização excessiva de medicação pode possivelmente ser aliviado e/ou encurtado através da medicação com corticoides, em particular prednisolona $(60 \mathrm{mg} 2$ 
dias, com redução progressiva de $20 \mathrm{mg}$ a cada 2 dias até suspensão ou $100 \mathrm{mg}$ por dia, durante 5 dias) ${ }^{13,19}$ - recomendação grau II, nível B. A considerar utilização concomitante de inibidores da bomba de protões, sobretudo em doentes com utilização excessiva de AINEs concomitante, que apresentam risco acrescido de ulceras pépticas ${ }^{24}$ - recomendação grau llb, nível C. O celecoxib oral $(400 \mathrm{mg} / \mathrm{dia}$ durante 5 dias, com redução de 100 mg/dia a cada 5 dias) pode ter efeito semelhante - recomendação grau Ilb, nível $\mathrm{C}$.

- O tratamento do agravamento das cefaleias na síndrome de abstinência com AINEs (em particular naproxeno e ácido tofenamico) ou sumatriptano não é recomendado ${ }^{23,25}$ - grau de recomendação Ilb, nível C.

- O tratamento do agravamento das cefaleias na síndrome de abstinência com dihidroergotamina (DHE) endovenosa (em esquema ou perfusão contínua, em regime de hospital de dia ou internamento) é utilizado frequentemente em centros dos Estados Unidos, embora não haja evidência da sua eficácia ${ }^{26-28}$ - recomendação grau lla, nível C. $\bigcirc$ risco de efeitos secundários desta terapêutica é de cerca de $50 \%$ sobretudo náuseas e vómitos (30\%), cãibras, crise hipertensiva, ${ }^{29}$ existindo ainda riscos associados ao seu uso prolongado e interações medicamentosas relevantes.

- O tratamento do agravamento das cefaleias na síndrome de abstinência com outros agentes, nomeadamente divalproato de sódio (dose de carga $15 \mathrm{mg} / \mathrm{kg}$, seguido por $5 \mathrm{mg} / \mathrm{kg}$ de $8 / 8$ horas) $)^{30}$ ou perfusão de lidocaína IV $(2 \mathrm{mg} /$ minutos por 7 a 10 dias) não tem evidência de eficácia - recomendação grau Ilb, nível $\mathrm{C}$.

- A utilização de terapêutica sintomática para os sintomas de abstinência com antieméticos, neurolépticos e hidratação endovenosa para as náuseas e vómitos, amitriptilina ou outros sedativos para insónia, beta-bloqueantes para tremor e taquicardia $^{13,16}$ não tem suporte científico ${ }^{23,31}$ - recomendação grau Ilb, nível C.

3. Terapêutica para a cefaleia de utilização excessiva de medicação

- A utilização de topiramato nas doses de $100 \mathrm{mg}$ por dia durante pelo menos 8 semanas associado com triptanos orais em regime $\operatorname{SOS}^{32}$ ou nas doses de 50 a $200 \mathrm{mg}$ durante pelo menos 12 semanas $^{33}$ é provavelmente útil, com o objetivo de reduzir o número de dias com enxaqueca e a utilização excessiva de analgésicos em doentes com enxaqueca crónica e utilização excessiva de medicação. Não existe evidência que permita recomendar a sua utilização sem a suspensão da utilização excessiva de medicação e deve ser considerado o elevado risco de abandono do tratamento por efeitos adversos ${ }^{13,33}$ - recomendação grau Ilb, nível de evidência $B$.

- Quando associada à suspensão da utilização excessiva de medicação, a utilização de pregabalina 100 a $150 \mathrm{mg} /$ dia durante pelo menos 16 semanas parece ser tão eficaz como o topiramato 50 a $100 \mathrm{mg} / \mathrm{dia}$ durante 16 semanas $^{34}$ - recomendação grau IIb, nível de evidência $C$.

- A utilização de valproato semisódico 800 mg/dia durante 12 semanas associado à suspensão da utilização excessiva de medicação parece ser superior à suspensão isolada da medicação na redução do número de dias de dor de cabeça ${ }^{35,36}$ - recomendações grau Ilb, nível C.

- A utilização de preventivos orais incluindo valproato de sódio, propranolol, topiramato, amitriptilina, flunarizina e inibidores seletivos da recaptação da serotonina no início ou precocemente (em dias) após a suspensão da utilização excessiva de medicação pode ser eficiente na redução da frequência das cefaleias e da redução da utilização excessiva de medicação ${ }^{13,15,17}$ - recomendações grau Ila, nível de evidência $B$.

- Em doentes com enxaqueca e outras cefaleias associadas a utilização excessiva de medicação o início de preventivos orais de acordo com a decisão clínica (incluindo candesartan, amitriptilina, gabapentina, divalproato de sódio e beta-bloqueantes) sem suspender a utilização excessiva de medicação pode ser superior à suspensão abrupta isolada da utilização excessiva de medicação na redução do número de dias com dor de cabeça, aos 3 meses, apresentando menor taxa de desistências, ${ }^{15,37}$ pelo que pode ser considerada como opção terapêutica9 - recomendação grau IIB, nível de evidência C.

- A utilização de toxina onabotulínica tipo A associada à suspensão da utilização excessiva de medicação em doentes com enxaqueca crónica e utilização excessiva 
de medicação não tem benefício adicional sobre a suspensão da utilização excessiva de medicação isoladamente, nem utilizando 100 unidades ( 10 nos músculos frontais, 5 nos corrugadores, 5 nos temporais, 10 nos para-espinhais cervicais e 10 nos trapézios) ${ }^{38}$ nem 155 Unidades segundo o protocolo PREEMPT $^{39}$ - recomendação grau II, nível de evidência $A$.

- Para tratamento da cefaleia por utilização excessiva de analgésicos a utilização de nabilona, acupuntura, bloqueio anestésico do occipital ou estimulação do nervo occipital não tem suporte científico robusto, não devendo ser considerada ${ }^{15}$ - recomendação grau IIB, nível de evidência $C$.

\section{Prevenção da recorrência}

- Em doentes com enxaqueca crónica e utilização excessiva de medicação que suspendam abruptamente a utilização excessiva de medicação durante 2 meses cerca de $42 \%$ a $56 \%$ reverte para enxaqueca episódica no entanto entre $74 \%$ a $85 \%$ ainda apresenta uma frequência de crises que justifica a introdução de medicação preventiva para a enxaqueca $^{21}$ e a introdução dessa medicação apresenta uma taxa de resposta melhor do que antes da suspensão da utilização excessiva de medicação ${ }^{20,31}$ recomendação grau II, nível de evidência C.

- A taxa de recorrência da cefaleia por utilização excessiva de medicação é de cerca de $13 \%$ a $34 \%$ aos 6 meses, e de $17 \%$ a $43 \%$ após um ano, sendo que a maioria dos doentes (94\%) recai no primeiro ano após suspensão. A recaída no primeiro é um preditor significativo para a obtenção de remissão sustida a longo prazo (4 anos), pelo que é recomendada a introdução de medicação preventiva em monoterapia para a cefaleia primária, de forma a evitar a recorrência ${ }^{13,15,23,40}$ - recomendação de grau I, nível de evidência $B$.

- Ter apoio de um enfermeiro ou de uma ferramenta eletrónica que permita o contacto com profissionais de saúde de forma a manter a utilização de analgésicos no limite de segurança (no máximo 2 dias por semana $)^{40}$ pode diminuir o risco de recaída em doentes que suspendam a utilização excessiva de analgésicos, associada ou não ao início precoce de preventivos $^{17}$ - recomendação de grau II, nível de evidência $C$.

- Dado o risco de recorrência, é recomendado o se- guimento e educação regular destes doentes 9 , 13,16,40 - recomendação de grau I, nível de evidência C (boa prática clínica)

- A utilização de topiramato nas doses de 50 a 200 mg por dia durante 12 semanas é uma terapêutica profilática eficaz para a enxaqueca crónica, mesmo em doentes com utilização excessiva de medicação que não tenham sido sujeitos a suspensão da utilização excessiva de medicação9,33 - recomendação grau II, nível $A$.

- A utilização de toxina onabotulínica tipo A, 155 a 195 unidades segundo o protocolo PREEMPT a cada 12 semanas é uma terapêutica profilática eficaz para a enxaqueca crónica, mesmo em doentes com utilização excessiva de medicação que não tenham sido sujeitos a suspensão da utilização excessiva de medicação $0^{9,41}$ - recomendação grau II, nível A.

- O erenumab 70 a 140 mg 4/4 semanas durante 3 meses é provavelmente eficaz na redução da frequência da enxaqueca em doentes com enxaqueca crónica e utilização excessiva de medicação que não suspendam a utilização excessiva de medicação 9,42,43 - recomendação grau II, nível de evidência B.

- O fremanezumab $675 \mathrm{mg}$ trimestral ou $675 \mathrm{mg}$ (dose de carga) seguido de 225 mg de 4/4 semanas pode ser eficaz na redução de dias de ingestão de medicação aguda às 12 semanas em doentes com enxaqueca crónica e utilização excessiva de medicação que não suspendam a utilização excessiva de medicação ${ }^{9,44}$ - recomendação grau lla, nível de evidência $B$.

- O galcanezumab 120 ou 240 mg 4/4 semanas durante 3 a 6 meses parece ser tão eficaz na redução dos dias com enxaqueca e dos dias de ingestão de medicação aguda nos doentes com enxaqueca crónica quer tenham quer não tenham cefaleia por utilização excessiva de medicação associada, que não suspendam a utilização excessiva de medicação ${ }^{45}$ recomendação grau Ila, nível de evidência $B$.

\section{Abordagem integrada}

- A prevenção primária da cefaleia por utilização excessiva de medicação pode passar por campanhas educativas populacionais, que melhoram o conhecimento sobre a patologia, muito embora se desconheça o impacto na diminuição da sua frequência ou severidade ${ }^{9,46}$ - recomendação grau lla, nível de 
evidência $C$.

- A prevenção primária da cefaleia por utilização excessiva de medicação deve incluir procedimentos educativos a doentes em risco, com elevada frequência de cefaleias, quer seja efetuada por folhetos informativos, consultas de cuidados de saúde primária ou centros especializados ${ }^{46}$ - recomendação grau Ila, nível de evidência $C$.

- Existem fatores preditores de maior risco de recorrência, tais como doença psiquiátrica (incluindo o tipo de personalidade, a tendência para a dependência, ansiedade e depressão) as condições socioeconómicas (baixa qualidade de vida, ser solteiro(a), desemprego e consumo regular de café, álcool e tabaco) e a maior severidade da doença inicial, traduzida pela maior intensidade de dor, frequência de crises, duração de doença, pontuação na MIDAS, número de consultas prévias e ter associadas alterações do sono e outras dores corporais crónicas $^{15,17}$ embora a utilidade do controle destes fatores não esteja demonstrada em termos de meIhoria do prognóstico ${ }^{18,40}$ - recomendação de grau Ila, nível $\mathrm{C}$.

- Mesmo em doentes sem estes fatores de risco, a implementação de medidas adicionais tais como terapêutica comportamental (relaxamento, gestão de ansiedade, biofeedback) e medidas de estilo de vida (diminuição do consumo de cafeína e álcool, suspensão do tabagismo, medidas de higiene de sono, um programa de exercício regular e regime alimentar equilibrado e regular) pode ser considerada, embora sem documentação da sua utilidade ${ }^{40}$ - recomendação de grau Ila, nível de evidência C.

- O tratamento multidisciplinar incluindo enfermeiros, psicólogos e fisioterapeutas pode ser útil no controle das cefaleias crónicas associadas à utilização excessiva de medicação, sobretudo nos casos mais complexos e com mais comorbilidades ${ }^{23,47}$ recomendação de grau lla, nível de evidência $C$.

- O tratamento da cefaleia por utilização excessiva de analgésicos pode reduzir o impacto da ansiedade e depressão associadas ${ }^{47}$ - recomendação de grau Ila, nível de evidência $C$.

- O tipo de fármaco utilizado em excesso pode igualmente influenciar o risco de recorrência, sendo que os utilizadores excessivos de opioides apresentam pior prognóstico e os utilizadores excessivos de triptanos o melhor prognóstico. Dados sobre a utilização de analgésicos de combinação (contendo cafeína ou butabital), analgésicos simples e ergotamínicos é controversa. ${ }^{15}$ Não existe evidência que suporte que a alteração do fármaco utilizado em excesso como medida de controlo da cefaleia por uso excessivo de medicação - recomendação grau III, nível de evidência $C$.

\section{RESUMO DAS ORIENTAÇÕES TERAPÊUTICAS}

- Os doentes com cefaleia por utilização excessiva de medicação devem ser educados sobre a patologia e aconselhados a suspender a medicação utilizada em excesso - recomendação grau I, nível B (boa prática clínica).

- A suspensão da utilização excessiva de medicação é recomendada, dado que é uma medida eficiente e consensual para diminuir a frequência das cefaleias - recomendação grau I, nível B - e provavelmente melhora a resposta da cefaleia primária inicial à terapêutica profilática - recomendação grau II, nível C.

- A suspensão da utilização excessiva de medicação ou destoxificação pode ser efetuada em regime de ambulatório - recomendação grau I, nível A - e de forma abrupta - recomendação grau llb, nível C, devendo ser recomendada a abstinência total dos analgésicos durante 2 meses (recomendação grau II, nível de evidência $C$ ). Pode-se considerar a descontinuação progressiva e/ou em regime de internamento em casos mais complexos e de risco de abstinência mais complexa - recomendação grau Ilb, nível C.

- A síndrome de abstinência de analgésicos e/ou triptanos após suspensão abrupta da utilização excessiva de medicação pode ser aliviado e/ou encurtado através da medicação com prednisolona - recomendação grau II, nível B.

- Não deve ser iniciada medicação farmacológica com topiramato, divalproato de sódio, pregabalina (recomendação grau Ilb, nível de evidência $C$ ) ou toxina onabotulínica tipo A (recomendação grau II, nível de evidência $A$ ) sem ser efetuada a suspensão da utilização excessiva de medicação.

- Embora a suspensão abrupta isolada da medicação seja eficaz na redução do número de dias com dor 
de cabeça (recomendação grau II, nível de evidência C), a introdução simultânea/ precoce de preventivos orais é provavelmente superior na redução da frequência das crises, avaliada aos 3 meses (recomendação grau Ilb, nível de evidência C), pelo que se recomenda que seja efetuada precocemente ou ainda antes da suspensão da medicação, se possível. $^{13}$

- É recomendada introdução de medicação preventiva para a cefaleia primária após tratamento da cefaleia por uso excessivo de medicação de forma a evitar a sua recorrência - recomendação de grau I, nível de evidência $B$, sendo igualmente recomendado o seguimento regular destes doentes ${ }^{13}-$ recomendação de grau I, nível de evidência C (boa prática clínica).

- Em doentes com enxaqueca e outras cefaleias associadas a utilização excessiva de medicação, o início de preventivos orais de acordo com a decisão clínica (incluindo candesartan, amitriptilina, gabapentina, divalproato de sódio e beta-bloqueantes) sem suspender a utilização excessiva de medicação pode ser considerada como opção terapêutica recomendação grau Ilb, nível de evidência C.

- O topiramato e a toxina botulínica parecem ser tão eficazes na redução dos dias com enxaqueca e/ou dias de ingestão de medicação aguda em doentes com enxaqueca crónica independentemente de apresentarem cefaleia por utilização excessiva de medicação - recomendação grau II, nível A.

- Os anticorpos monoclonais erenumab, fremanezumab e galcanezumab parecem ser tão eficazes na redução dos dias com enxaqueca e/ou dias de ingestão de medicação aguda em doentes com enxaqueca crónica independentemente de apresentarem cefaleia por utilização excessiva de medicação - recomendação grau lla, nível de evidência B.

- Dado o risco de recorrência, é recomendado o seguimento e educação regular dos doentes que efetuem o tratamento de cefaleias crónicas associadas a utilização excessiva de medicação, reforçando a necessidade de cumprir o limite máximo de 2 dias com medicação analgésica por semana - recomendação de grau I, nível de evidência C (boa prática clínica).

- Nos doentes mais complexos, com maior risco de recorrência e com comorbilidades pode ser útil uma abordagem multidisciplinar incluindo enfer- meiros, psicólogos e fisioterapeutas que permita implementação de medidas adicionais (terapêutica comportamental e medidas de estilo de vida), controle sintomático das comorbilidades, assim como um método de contacto mais próximo com os profissionais de saúde - recomendação de grau lla, nível de evidência $C$.

\section{SITUAÇÕES ESPECIAIS}

\subsection{RECOMENDAÇÕES TERAPÊUTICAS PARA AS CEFALEIAS PRIMÁRIAS NA POPULAÇÃO PEDIÁTRICA}

\section{A - Enxaqueca}

Apesar da elevada prevalência da enxaqueca $(2,7 \%$ $10 \%)$ na população pediátrica, esta continua a ser subdiagnosticada e subtratada.

O seu diagnóstico é mais difícil na criança pela dificuldade de esta expressar as características das suas cefaleias. Algumas das particularidades da enxaqueca da criança são atualmente reconhecidas na nova classificação internacional das cefaleias (ICHD-3): duração mais curta dos episódios, localização bilateral e proeminência das manifestações gastrointestinais (dor abdominal, náuseas e vómitos). ${ }^{1,2}$

Há poucos ensaios clínicos randomizados e controlados com placebo sobre o tratamento agudo e sobre a profilaxia da enxaqueca na pediatria, e está demonstrada nas crianças uma alta resposta ao placebo, o que dificulta as orientações terapêuticas que muitas vezes são adaptadas dos estudos dos adultos. ${ }^{3}$

As cefaleias, tal como outras dores, são um fenómeno com componente biopsicossocial e assim o tratamento terá que ser sempre interdisciplinar e multimodal. ${ }^{4}$

\section{Medidas gerais}

tratamento da enxaqueca pediátrica deve incluir o envolvimento dos pais/cuidadores e da escola. $\mathrm{Na}$ escola devem ser criadas condições para que a criança possa tomar precocemente a medicação e repousar ou dormir num local escuro e silencioso. Deve-se educar a criança e a família sobre a enxaqueca, nomeadamente como atuar na fase aguda, relembrando a importância de evitar o abuso de analgésicos (não usar mais de 3 dias por semana fármacos como paracetamol ou anti-inflamatórios não esteroides, AINEs, e não usar mais de 
2 dias por semana os triptanos). Deve-se reforçar a necessidade de modificar o estilo de vida e tentar corrigir possíveis fatores precipitantes das crises de enxaqueca. Um dos sítios que poderá ser aconselhado aos pais e aos jovens consultar é headachereliefguide.com.

Exercício físico e alimentação - Apesar de na criança haver poucos estudos, recomenda-se a prática de exercício físico e evitar saltar refeições, particularmente o pequeno-almoço (grau Ila, nível C). O controlo da obesidade (grau I-Ila, nível B) mostrou ser importante na prevenção da cefaleia crónica. ${ }^{5,6}$ Também o aumento do aporte de água está associado a melhoria da gravidade da cefaleia e da qualidade de vida no adulto. Não foram feitos estudos na criança, mas sabe-se que $55 \%$ dos jovens com idades 6-19 estavam ligeiramente desidratados pela análise da concentração urinária. ${ }^{7}$

Sono - Tentar manter período de sono adequado à idade e horários regulares (grau I-II, nível C) podendo seguir as recomendações da Academia Americana Medicina do Sono. ${ }^{8}$ Excluir e tratar patologia do sono.

Relaxamento (grau I-lla, nível C) - O stress pode precipitar as crises de enxaqueca. Há várias técnicas de relaxamento que as crianças e adolescentes podem facilmente treinar (técnicas de respiração diafragmática, técnica de relaxamento muscular progressivo, relaxamento usando imagens ou pensar num local preferido.)

\section{Tratamento Sintomático}

A medicação deve ser tomada nas doses eficazes e o mais precocemente possível, enquanto a dor não é muito intensa e com o objetivo de controlar a crise em I a 2 horas. $O$ tratamento sintomático da crise de enxaqueca na pediatria está resumido na Tabela 9.1.

Nos episódios ligeiros a moderados os fármacos de primeira linha utilizados habitualmente são o ibuprofeno (grau I, nível A) e o paracetamol (grau I, nível B) que demonstraram eficácia e segurança no tratamento sintomático da enxaqueca na criança. $\mathrm{O}$ ibuprofeno foi

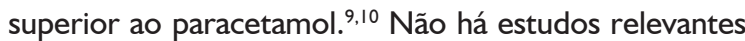
relativamente ao uso de outros AINEs como o naproxeno, o cetorolac, o diclofenac ou a indometacina no tratamento da enxaqueca na pediatria (grau Ila, nível C). Os produtos contendo aspirina devem ser evitados abaixo dos 16 anos para evitar risco da síndrome de Reye. "I

Se os episódios são acompanhados de náuseas ou vómitos deve usar-se precocemente um antiemético que, para além de aliviar esses sintomas, causa sonolência.
Há poucos estudos com antieméticos na enxaqueca na criança. A prometazina $(0,25-0,5 \mathrm{mg} / \mathrm{kg} /$ dose po ou retal) é um dos mais usados nas crianças acima dos 2 anos por ser eficaz e ter poucos efeitos extrapiramidais (grau Ila, nível C). A proclorperazina (grau lla, nível B) e a metoclopramida (grau lla, nível C) mostraram ser mais eficazes mas parecem ter mais efeitos extrapiramidais. ${ }^{12,13}$

Nos episódios moderados a graves que são refratários aos fármacos de primeira linha devemos utilizar os triptanos, que são o grupo de fármacos com mais estudos na enxaqueca pediátrica. São eficazes e bem tolerados, mas os resultados dos ensaios clínicos são variáveis e inconsistentes. $\mathrm{Na}$ criança ou adolescente os principais efeitos secundários reportados nos estudos com os triptanos orais foram: fadiga, tonturas, astenia, boca seca, náuseas e vómito. Nos triptanos nasais os principais efeitos secundários foram: alteração do sabor, sintomas nasais e náuseas. ${ }^{14}$ Tal como no adulto também devem ser evitados nas crianças com história de AVC ou doença vascular periférica. Avaliar sempre a TA antes de prescrever triptanos. $\mathrm{Na}$ Tabela 9.1 estão assinalados os principais triptanos. A escolha vai depender da idade e das formulações disponíveis.

O almotriptano e o rizatriptano têm evidência (grau I, nível A) da sua eficácia via oral estando aprovados pela FDA para usar no adolescente e na criança. ${ }^{15}$

Nas crianças ou adolescentes que não respondem à monoterapia podemos associar triptano com AINE. Dois estudos randomizados e controlados com placebo, utilizaram associação sumatriptano/naproxeno em jovens dos 12 aos 17 anos e mostram eficácia superior ao placebo com boa tolerabilidade, mas com mais efeitos secundários comparativamente ao placebo (grau I, nível $\mathrm{A}){ }^{16,17}$

Outros triptanos orais (zolmitriptano, sumatriptano, frovatriptano, eletriptano e narotriptano) não se mostraram eficazes no tratamento da enxaqueca na idade pediátrica (grau Ilb, nível A). ${ }^{15}$

O sumatriptano spray nasal e o zolmitriptano spray nasal são eficazes na enxaqueca em idade pediátrica (grau I, nível $A^{15}$ ).

Relativamente ao sumatriptano subcutâneo (SC) há apenas 2 pequenos ensaios com jovens dos 6-18 anos que mostrou ser eficaz, mas com percentagem alta de efeitos secundários (grau llb, nível B)..$^{18,19}$ 
Tabela 9.1. Fármacos usados no tratamento agudo da enxaqueca na pediatria

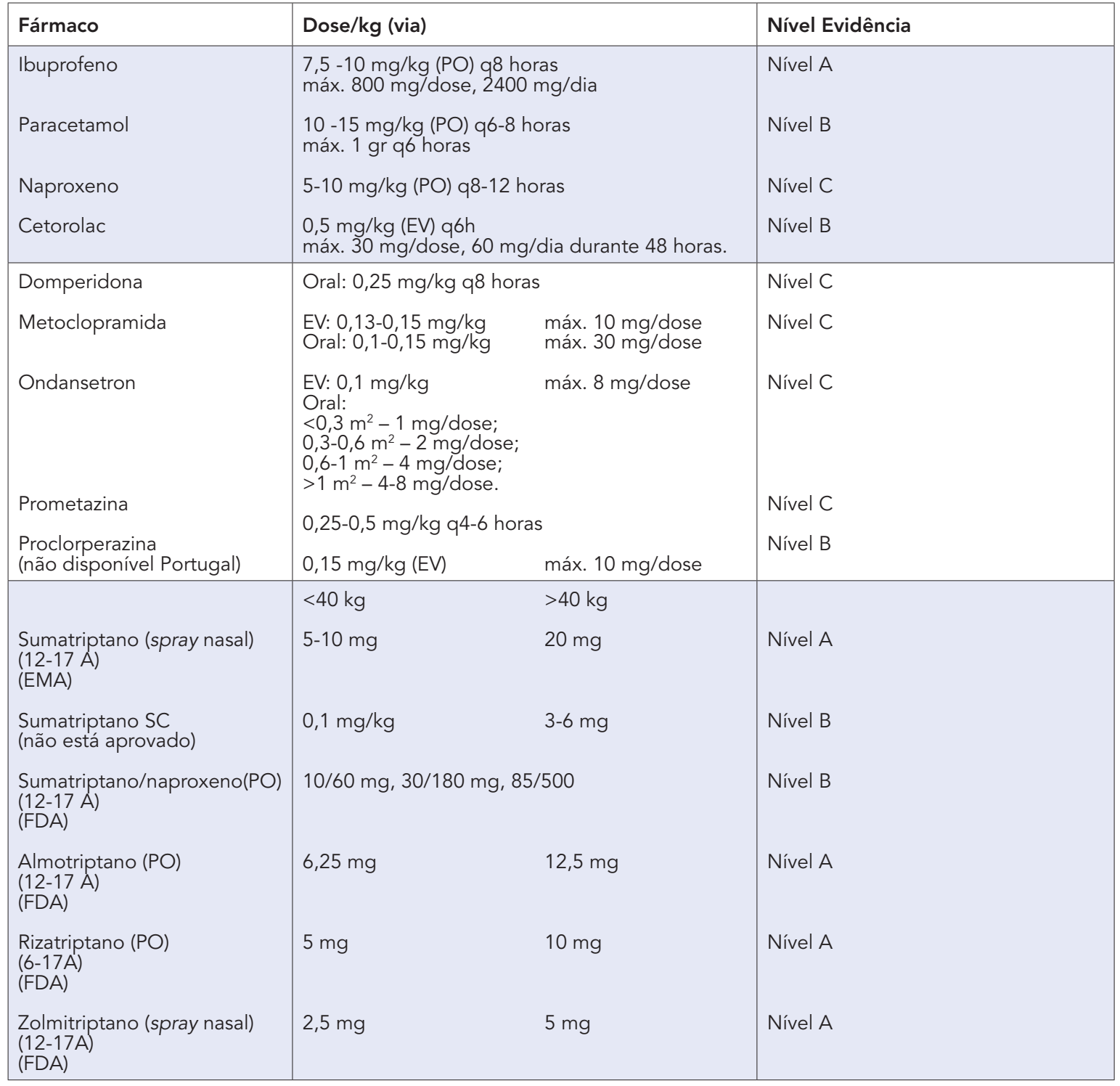

\section{A1) Enxaqueca no serviço de urgência (SU) de pediatria}

A abordagem da enxaqueca no SU de pediatria deve basear-se nos mesmos princípios de tratamento dos episódios moderados a graves, mas com possibilidade de usar a via endovenosa (EV). Há apenas um estudo prospetivo randomizado duplamente cego que mostra a eficácia do cetorolac EV (grau lla, nível B) no tratamento da enxaqueca, mas quando comparado com a proclorperazina EV, esta última mostrou ser mais eficaz (grau lla, nível B). ${ }^{20}$ Outros estudos retrospetivos também apoiam estes dados". Antes de administrar qualquer fármaco no SU confirmar sempre a medicação que foi feita em ambulatório (fármaco, dose, horário). No SU nos casos graves com muitos vómitos é útil iniciar fluidoterapia $\mathrm{EV}$. Não há protocolo ideal, varia em função da experiência e dos fármacos disponíveis, por exemplo: fluidoterapia EV + proclorperazina seguida de cetorolac EV (grau lla, nível C) ou fluidoterapia EV+metoclopramida (grau Ilb, nível C). Outros fármacos: valproato EV - a evidência do seu benefício no tratamento da enxaqueca é limitada (nível C). ${ }^{21}$ Um estudo retrospetivo com 31 crianças no $\mathrm{SU}$ (idade média 15 anos) documentou melhoria significativa com boa tolerância. ${ }^{22}$

Não devem ser usados no tratamento sintomático da enxaqueca na pediatria os derivados da ergotamina e os opióides, dada a má relação eficácia/tolerabilidade (grau III, nível B). ${ }^{23,24}$ 


\section{Tratamento profilático}

O tratamento preventivo da enxaqueca está indicado se as crises são frequentes ou prolongadas, se interferem com as atividades vida diária, se há contraindicação para uso dos fármacos para tratamento agudo, se o tratamento sintomático é ineficaz, se há risco de cefaleia por abuso medicamentoso e na enxaqueca menstrual.

\section{I- Tratamento farmacológico}

Há poucos estudos na pediatria sobre a eficácia dos fármacos usados na profilaxia da enxaqueca. A escolha do fármaco deve ser individualizada e tendo em atenção os efeitos secundários e comorbilidades. Deve-se iniciar com uma dose baixa e ir titulando até obter benefício, atingir a dose máxima ou surgirem efeitos secundários importantes. A duração ideal do tratamento não está estudada, na prática a maioria dos autores recomenda no mínimo 3 meses e se eficaz manter durante 6 a 12 meses.

São vários os fármacos usados no tratamento profilático da enxaqueca na criança ou adolescente, mas apenas o topiramato tem aprovação pela FDA na faixa etária dos 12-17 anos. Não há qualquer fármaco aprovado abaixo dos 12 anos. ${ }^{25}$

A experiência clínica e a extrapolação de estudos dos adultos permitem utilizar alguns fármacos apesar de não estarem suficientemente estudados na criança:

Propranolol (grau lla, nível C) - há poucos estudos na criança e com diferentes resultados. ${ }^{26-28}$ As doses habitualmente usadas são $1-3 \mathrm{mg} / \mathrm{kg} /$ dia repartido em 3 tomas. Deve-se monitorizar FC e TA a cada 3 meses. Evitar o seu uso nas crianças com asma, diabetes ou depressão.

Amitriptilina (grau lla, nível B) - também os estudos são limitados na pediatria. ${ }^{29,30} \mathrm{~A}$ dose ideal não foi estabelecida, e as recomendações variam. Pode iniciar-se com 5- 10 mg em dose única à noite e aumentar 0,25 $\mathrm{mg} / \mathrm{kg} /$ dia a cada 2 semanas. Principais efeitos secundários: sedação, aumento peso, hipertensão, boca seca, retenção urinária, alterações ECG (deve-se realizar ECG se doses $>1 \mathrm{mg} / \mathrm{kg} /$ dia.)

Nortriptilina - não há estudos randomizados na criança/adolescente.

Topiramato - Os resultados sobre a sua eficácia como profilático da enxaqueca na criança são contraditórios (grau lla, nível A). ${ }^{30,31}$

É atualmente o único fármaco aprovado pela FDA para uso em crianças 12-17 anos como profilático da enxaqueca com base nos resultados de um estudo randomizado, duplamente cego e placebo-controlo. ${ }^{32}$

Pode iniciar-se com 0,5-1 mg/kg/dia e ir aumentando semanalmente até $2-3 \mathrm{mg} / \mathrm{kg} / \mathrm{dia}$ (máximo $100 \mathrm{mg}$ ). Principais efeitos secundários: alterações cognitivas, perda de apetite (cuidado com o uso nos adolescentes com suspeita de anorexia), perda ponderal, parestesias e cálculos renais.

Flunarizina (grau lla, nível B) - pode ser eficaz, mas há poucos estudos RCP. ${ }^{33}$ Pode iniciar-se com $5 \mathrm{mg}$ dose única à noite e aumentar até $10 \mathrm{mg}$. Principais efeitos secundários: sedação e aumento peso.

Valproato (grau lla, nível B) - poderá ser eficaz, mas os estudos na pediatria são limitados. ${ }^{34}$ Doses sugeridas $10-30 \mathrm{mg} / \mathrm{kg} /$ dia repartido em 2 tomas. Principais efeitos secundários: sedação, tonturas, aumentam apetite. Evitar o seu uso antes dos 5 anos (risco de hepatotoxicidade) e nas jovens em idade reprodutiva (teratogenicidade).

Gabapentina, levetiracetam (grau Ilb, nível C,): poucos estudos de qualidade. ${ }^{35,36}$

Um ensaio multicêntrico controlado randomizado com crianças e adolescentes (8- I7 anos) (CHAMP Study - Childhood and Adolescent Migraine Prevention Trial) mostrou que nos três braços do estudo (amitriptilina (I $\mathrm{mg} / \mathrm{kg}$ ), topiramato (2 mg/kg) e placebo) cerca de $60 \%$ obtiveram uma redução $\geq 50 \%$ nos dias com cefaleias, 24 semanas após o início do tratamento profilático. topiramato não foi superior à amitriptilina ou ao placebo. Os efeitos secundários foram superiores no grupo da amitriptilina e do topiramato comparativamente ao placebo. ${ }^{30,37}$ Estes resultados têm levado a questionar a sua utilidade no tratamento da enxaqueca recorrente.

Estão a ser preparados na pediatria ensaios com os

\section{Ac monoclonais anti-CGRP. ${ }^{38}$}

Até haver resultados um grupo de peritos reuniu e publicou um artigo com algumas recomendações (ver Tabela 9.2), onde defendem que estes fármacos poderão ser utilizados em casos selecionados, mas mantendo um seguimento apertado e tendo sempre em consideração as características do doente como a idade, estado pubertário e comorbilidades médicas. ${ }^{39}$ 
Tabela 9.2. Sugestões de indicações, contraindicações e monitorização para o uso dos Ac monoclonais anti-CGRP e anti-rCGRP nas crianças e adolescentes com enxaqueca ${ }^{39}$

\begin{tabular}{|c|c|c|}
\hline Indicações & Contraindicações & Monitorização \\
\hline $\begin{array}{l}\text { - } \geq 8 \text { dias/mês com cefaleias } \\
\text { - PedMIDAS } \geq 30 \\
\text { - Ineficácia de } \geq 2 \text { tratamentos } \\
\text { preventivos (farmacológicos e/ou não } \\
\text { farmacológicos) } \\
\text { - Adolescente pós-pubertário ou crianças } \\
\text { pré-púberes em casos selecionados }\end{array}$ & $\begin{array}{l}\text { - Alteração da barreira hemato } \\
\text { encefálica (ex: história de meningite } \\
\text { recente, neurocirurgia recente) } \\
\text { - Doença cardiovascular grave, AVC } \\
\text { - Amamentação, gravidez, ou plano } \\
\text { para engravidar. }\end{array}$ & $\begin{array}{l}\text { - Estado pubertário } \\
\text { - Estado do osso, considerar } \\
\text { doseamento vitamina D } \\
\text { - Crescimento linear } \\
\text { - Peso/ índice massa corporal } \\
\text { - Infeções } \\
\text { - Possibilidade de gravidez }\end{array}$ \\
\hline
\end{tabular}

\section{2- Tratamento nutracêutico}

A vitamina B 12 (riboflavina) é o suplemento mais estudado ( 25 a $400 \mathrm{mg} \mathrm{Ix/dia)} \mathrm{mas} \mathrm{a} \mathrm{evidência} \mathrm{da} \mathrm{sua}$ eficácia na pediatria é limitada e inconclusiva (grau Ilb, nível B). ${ }^{40,41}$

A melatonina $3 \mathrm{mg} / \mathrm{d}$ poderá ser eficaz (grau lla, nível $B / C)^{42,43}$

Outros suplementos como o magnésio e a coenzima Q10 apresentam dados limitados e de baixa qualidade (grau IIB, nível C). ${ }^{40}$

\section{3- Tratamento psicológico}

- Terapia cognitivo-comportamental (TCC): Vários estudos demonstraram a eficácia da TCC no controlo da cefaleia crónica e recorrente na criança (grau I-Ila, nível B). ${ }^{44}$ A TCC pode incluir várias estratégias: psicoeducação da criança e dos cuidadores, respiração diafragmática, relaxamento muscular progressivo, imaginação guiada, técnicas de distração, etc. ${ }^{45}$ Alguns dos estudos demonstram eficácia da TCC aplicada via Internet. ${ }^{46}$

- Biofeedback: é frequentemente usado e com bons resultados na enxaqueca pediátrica (grau l-Ila, nível B). ${ }^{47}$

- Técnicas de relaxamento (grau lla, nível C) (respiração diafragmática, relaxamento muscular progressivo, imaginação guiada, meditação): poucos estudos na criança.

\section{A2) Síndromes episódicas que podem estar associadas a enxaqueca}

Na pediatria é fundamental fazer o correto diagnóstico das síndromes episódicas que podem estar associados a enxaqueca que fazem parte da ICHD-3. Não há até à data estudos que permitam fornecer orientações terapêuticas. Relativamente à síndrome dos vómitos cíclicos e à enxaqueca abdominal têm sido sugeridos alguns tratamentos na crise, utilizando antieméticos, triptanos (sumatriptano SC e intranasal) e nutracêuticos (grau lla, nível C) e na profilaxia utilizando principalmente a amitriptilina nas crianças $>5$ anos (grau lla, nível B). ${ }^{48-51}$

Em resumo, as evidências atuais sugerem que a meIhor forma de tratar a enxaqueca na criança e adolescente deve envolver um tratamento interdisciplinar multimodal. Integrando os dados da literatura atual uma possível proposta para tratar a enxaqueca pediátrica seria ${ }^{52}$ :

- Educação sobre hábitos vida saudáveis (sono, alimentação e exercício) e sobre perda de peso se tiver excesso de peso ou obesidade

- Educação sobre a importância do tratamento precoce da crise de enxaqueca e como evitar abuso medicamentoso.

- Utilizar no tratamento farmacológico agudo o ibuprofeno ou outro AINE e os triptanos.

- No tratamento preventivo usar:

a) Intervenção psicológica (TCC, biofeedback ou técnicas de relaxamento)

b) Intervenção farmacológica (não é claro se a atual intervenção é mais eficaz que o placebo)

c) Intervenção nutracêutica (não é claro se a atual intervenção é mais eficaz que o placebo).

\section{B - Cefaleia tipo tensão}

\section{Tratamento sintomático}

Usa-se habitualmente o ibuprofeno ou paracetamol (grau l, nível B). Um estudo randomizado comparou os 2 fármacos num grupo que incluiu jovens acima dos 12 anos e o ibuprofeno foi mais eficaz do que o paracetamol e do que o placebo. ${ }^{53}$

\section{Tratamento preventivo}

Não há estudos randomizados, controlados com pla- 
cebo, para orientar o tratamento preventivo das cefaleias de tensão na criança ou adolescente.

Poderá usar-se a amitriptilina, com base nos estudos dos adultos e na experiência clínica, nas mesmas doses das usadas na profilaxia da enxaqueca (grau lla, nível C).

O exercício físico ou a educação sobre cefaleias pode ser útil (nível B). ${ }^{54}$

A riboflavina $50 \mathrm{mg} /$ dia pode diminuir a frequência das cefaleias de tensão na criança ou adolescente (grau Ilb, nível B)..$^{55}$

A melatonina $3 \mathrm{mg} / \mathrm{dia}$ em toma única á noite pode ser eficaz (grau Ilb, nível C). ${ }^{56}$

\section{C - Cefaleias trigémino-autonómicas}

Cefaleias em salvas - são uma entidade rara na pediatria. Os tratamentos baseiam-se na experiência dos adultos e no relato de alguns casos clínicos (grau Ilb, nível C).

Tratamento agudo: Oxigénio 100\% (12 l/min) por máscara facial normobárica (mostrou ser eficaz e sem efeitos secundários). Poderá ser necessário associar triptano nasal ou SC (mesmas doses do tratamento da enxaqueca).

Tratamento preventivo: $\mathrm{Na}$ criança o intervalo longo entre as salvas torna a decisão de tratamento a longo prazo mais difícil. Quando necessário usam-se os fármacos estudados nos adultos que mostraram ser eficazes: verapamilo $3-10 \mathrm{mg} / \mathrm{kg} / \mathrm{dia}$ ou melatonina $0,1-0,2 \mathrm{mg} /$ $\mathrm{kg} / \mathrm{dia}$ ou topiramato $\mathrm{I}-2 \mathrm{mg} / \mathrm{kg} / \mathrm{dia} .{ }^{57}$ Os corticoides também mostraram ser eficazes na pediatria, na fase de transição após o tratamento agudo enquanto se aguarda efeito do tratamento preventivo. ${ }^{58}$

Hemicrania paroxística - dada a raridade na criança, os tratamentos baseiam-se na expêriencia dos adultos e relato de casos clínicos: indometacina $0,5-1 \mathrm{mg} / \mathrm{kg}$ 2x/dia (grau Ilb, nível C). ${ }^{59}$

\section{D - Outras cefaleias primárias \\ Cefaleia primária tipo guinada}

Cerca de $12 \%$ das crianças com idade inferior a 6 anos recorrem a uma consulta de cefaleias por causa de cefaleia tipo guinada. ${ }^{60} \mathrm{O}$ tratamento agudo não é necessário dada a curta duração dos episódios. Nos casos com episódios muito frequentes pode ponderar-se tratamento profilático. $\mathrm{Na}$ criança pequena pode tentar-se a melatonina I-3 mg à noite (grau IIB, nível C).

\section{Cefaleia hípnica}

Há uma série de 5 casos pediátricos descritos na literatura, com idades 7 - II anos, dois casos responderam à melatonina. ${ }^{61}$

\section{Cefaleia persistente diária desde início}

Esta entidade pode ser mais frequente nos adolescentes do que nos adultos. ${ }^{62}$

A cefaleia pode ter características de enxaqueca ou tipo tensão. Não havendo estudos sobre o melhor tratamento desta entidade, recomenda-se tratar em função das características da cefaleia.

\section{E - Cefaleia crónica}

$\mathrm{Na}$ pediatria a maioria dos estudos foram feitos para a enxaqueca crónica e cefaleia tipo tensão crónica.

O tratamento da cefaleia crónica deve começar pela prevenção do seu aparecimento. Embora na criança haja poucos estudos sobre fatores de riscos de evolução para cefaleia crónica, aceita-se com base em muitos estudos do adulto as seguintes estratégicas como tendo efeito positivo na evolução da enxaqueca com início na infância:

- Tratar precocemente e corretamente a enxaqueca.

- Utilizar estratégias comportamentais com objetivo de otimizar estilos de vida (alimentação saudável, higiene sono, exercício físico).

\section{I - Tratamento farmacológico}

A amitriptilina e o topiramato (grau Illb, nível B) têm sido os fármacos mais usados na clínica para tratamento da cefaleia crónica na pediatria. Um pequeno estudo randomizado (57 crianças dos 9-16 anos) comparou amitriptilina $(0,5 \mathrm{~kg} / \mathrm{kg} / \mathrm{d}$ ) com o topiramato (até $100 \mathrm{mg} / \mathrm{d}$ ) mostrando que ambos eram eficazes. ${ }^{63}$ Estudo recente multicêntrico de alta qualidade duplamente cego controlado com placebo para comparar a eficácia, mostrou taxas de resposta semelhantes entre a amitriptilina, o topiramato e o placebo. ${ }^{30}$

Toxina onabotulínica tipo A (grau llb, nível C) tem sido usada na pediatria na enxaqueca crónica com redução do número de dias com cefaleia. ${ }^{64}$ Ainda sem estudos suficientes que permitam a sua aprovação no tratamento da cefaleia crónica na pediatria.

Bloqueio nervo occipital (grau Ilb, nível C) (59 $^{59}$ tem sido usado de forma não protocolada na enxaqueca crónica e na cefaleia persistente diária de novo da criança com benefício e raros efeitos secundários. ${ }^{65,66}$ 


\section{2- Tratamento não farmacológico}

O tratamento da cefaleia crónica na pediatria deve ser multidisciplinar e para além da terapia farmacológica deve incluir educação sobre as cefaleias, estratégias comportamentais, técnicas de relaxamento, terapia cognitivo comportamental etc. ${ }^{67,68}$

Terapia cognitivo-comportamental (TCC) - Um estudo que comparou sessões TCC com sessões de educação sobre cefaleias mostrou melhoria da ansiedade depressão e incapacidade relacionada com a cefaleia, mas não melhorou a intensidade, frequência ou duração das cefaleias (grau lla, nível A). ${ }^{69}$

Associação TCC/amitriptilina (grau lla, nível A) Um estudo randomizado controlado estudou a associação da TCC + amitriptilina numa amostra de crianças (I0-17A) com enxaqueca crónica e os resultados mostraram um benefício superior ao uso de amitriptilina + educação sobre estilo de vida. ${ }^{70} \mathrm{Um}$ outro estudo com esta associação em crianças/adolescentes com enxaqueca crónica, mostrou redução do número de dias com cefaleia para $\leq 4 /$ mês. $^{71}$

Outro estudo com 137 jovens 10-17 anos com enxaqueca crónica comparou TCC com amitriptilina (I mg/ $\mathrm{kg} / \mathrm{dia}$ ) e com educação sobre cefaleias. A TCC mostrou ser superior relativamente à frequência ao número de dias com cefaleias e na incapacidade relacionada com a cefaleia. ${ }^{72} \mathrm{Um}$ ensaio randomizado controlado com TCC aplicada via internet durante 8 semanas mostrou redução no número de dias com cefaleias, intensidade da dor e sintomas depressivos. ${ }^{73}$

Apesar de haver vários estudos, a eficácia de outros tratamentos não farmacológicos (acupuntura, fisioterapia, realidade virtual e biofeedback, hipnose, nutracêuticos...) nas crianças com cefaleias crónicas ainda não está demonstrada ${ }^{74-76}$ (grau llb, nível C).

\subsection{RECOMENDAÇÕES TERAPÊUTICAS PARA AS CEFALEIAS PRIMÁRIAS NA MULHER EM FASE FÉRTIL, GRAVIDEZ, ALEITAMENTO E MENOPAUSA}

\section{Introdução}

A maioria das cefaleias primárias são mais prevalentes no género feminino, provavelmente devido às diferenças na perceção da dor condicionada pelo ambiente hormonal dado que as hormonas sexuais, em particular os estrogénios, atuam como reguladores da neurotransmissão.
Níveis elevados de estrogénios (como ocorrem na gravidez, durante a toma de contracetivos hormonais combinados ou nas terapêuticas hormonais de substituição de doses elevadas) potenciam a ação da serotonina, GABA e endorfinas (diminuindo a perceção dolorosa) e aumentam a suscetibilidade à ocorrência de depressão cortical alastrante, aumentando o risco de ocorrência de auras. ${ }^{1-3}$ A descida dos níveis de estrogénios (que ocorre na menstruação, pós-parto ou perimenopausa) potenciam a dopamina e norepinefrina, aumentando a perceção álgica e o risco de crises.' Os estrogénios têm a capacidade de modular a expressão do CGRP, uma das principais moléculas envolvidas na fisiopatologia da enxaqueca, em diferentes níveis do sistema trigeminovascular., ${ }^{2,3}$

Neste contexto, o tratamento das cefaleias na muIher pode diferir ao longo do ciclo reprodutivo dado que este condiciona mudanças na expressão da doença, sendo particularmente importante a adaptação da atitude terapêutica durante a gestação e amamentação, momentos em que o embrião/feto ou recém-nascido pode ser exposto a fármacos administrados à mãe.

Neste capítulo iremos apenas abordar apenas o tratamento das cefaleias primárias no contexto do ciclo reprodutivo feminino, não nos iremos debruçar sobre a avaliação nem tratamento das cefaleias secundárias. Chamamos a atenção que na gravidez, em particular, existe risco aumentado de um conjunto de patologias neurológicas que se podem manifestar com cefaleias, pelo que qualquer cefaleia de novo ou agravamento das cefaleias prévias ocorrendo neste contexto deve ser considerada como cefaleia secundária até prova em contrário. ${ }^{4}$

Como em qualquer outra situação clínica, o conhecimento sobre o efeito da medicação utilizada para controlar sintomaticamente as cefaleias durante a gravidez limita-se aos resultados de estudos em fase pré-clínica em animais, à exposição humana acidental durante a gravidez e por dados de farmacovigilância, pelo que o nível de evidência destas recomendações é sempre limitado (nível C). Aplicaremos assim neste capítulo, adicionalmente, a categorização da FDA (Food and Drug Administration) em relação ao risco de teratogenicidade dos fármacos, de forma a fornecer a melhor qualidade de informação possível, para a tomada de decisão terapêutica nestas situações. ${ }^{5}$ Como regras gerais, deve-se evitar a medicação no primeiro trimestre de gestação, deve-se utilizar a dose mais baixa possível durante o menor tempo possível e deve-se evitar a utilização de 
fármacos recentes, em termos de introdução no mercado, preferindo os que tenham um perfil de segurança melhor conhecido. ${ }^{5}$

Dividimos estas recomendações por patologia considerando cada fase do ciclo reprodutivo em separado.

\section{RECOMENDAÇÕES TERAPÊUTICAS}

\section{Enxaqueca}

\subsection{Enxaqueca menstrual}

- Cerca de $50 \%$ das mulheres tem regularmente crises de enxaqueca - sobretudo sem aura - na fase perimenstrual, o que se designa por enxaqueca menstrual; no entanto apenas $10 \%$ a $20 \%$ tem crises exclusivamente menstruais. $O$ nadir do nível de estrogénios determina o risco de ocorrência da crise, habitualmente nas 48 e 72 horas depois do primeiro dia de hemorragia. $^{2}$

- A manipulação hormonal pode ser considerada como estratégia de tratamento da enxaqueca menstrual; em mulheres com ciclos regulares a suplementação hormonal com gel de estradiol I,5 mg durante 5 a 7 dias na fase perimenstrual parece diminuir a ocorrência de enxaqueca, ${ }^{6,7}$ no entanto a utilização de estradiol transdérmico ( $100 \mu \mathrm{g} / 24$ horas) durante 2 semanas não demonstrou a mesma eficiência ${ }^{8}$ - recomendação grau II, nível C.

- Em mulheres com ciclos irregulares as estratégias de manipulação hormonal devem ter como objetivo a inibição da ovulação, podendo-se utilizar contracetivos orais combinados de forma contínua (sem interrupção) ou, como alternativas, o anel vaginal utilizado de forma contínua, os contracetivos apenas progestativos (desogestrel, aconselhados para os casos de enxaqueca com aura) ou a utilização de análogos da gonadotropina ${ }^{2,9}$ (recomendação grau lla, nível C).

- Com o objetivo de diminuir o risco da enxaqueca menstrual, a utilização de contraceção combinada com interrupções mais curtas (máximo 4 dias), ou com menor dose de estrogénios (20-30 $\mu \mathrm{g}$, dado que dose inferiores podem não inibir a ovulação de forma consistente) não parece ser eficaz ${ }^{2,9}$ - recomendação grau lla, nível $\mathrm{C}$.

- A profilaxia perimenstrual é uma estratégia que inclui a utilização de fármacos utilizados no tratamento sintomático das crises de enxaqueca de um modo profilático, na fase de maior risco de ocor- rência das crises ( 2 dias antes até 3 a 5 dias após o primeiro dia de hemorragia). Os fármacos com maior evidência de benefício neste contexto incluem o sumatriptano ( $100 \mathrm{mg}$ tid), rizatriptano 10 mg e o naproxeno (500 mg bid) $)^{2,3}$ - recomendação grau lla, nível B.

- Como alternativa pode considerar-se a utilização de sumatriptano $85 \mathrm{mg}+$ naproxeno $500 \mathrm{mg}$ (associação fixa comercializada nos EUA), ácido mefenâmico (500 mg tid), zolmitriptano (2,5 mg tid), frovatriptano (2,5 mg bid) e naratriptano ( $1 \mathrm{mg}$ bid) nos mesmos 5 a 7 dias $^{2,3}$ - recomendação grau II, nível C - ou mesmo magnésio 360 mg id da ovulação à menstruação ou fitoestrogeneos (genistein e daidzein) dos dias -7 to $+3^{2,3}$ - recomendação grau llb, nível C.

- Nas mulheres com ciclos regulares, a decisão sobre iniciar a profilaxia perimenstrual ou suplementação hormonal deve ser precedida por um registo diário de pelo menos 3 meses, de forma a analisar a regularidade das menstruações e a data de início da crise $^{3}$ - recomendação grau lla, nível C.

- A decisão sobre o tipo de estratégia perimenstrual a instituir pode ter em consideração a presença de dismenorreia associada (que pode beneficiar de anti-inflamatórios) ou de síndrome perimenstrual associada (que pode beneficiar de magnésio ou fitoestrogénios) ${ }^{3}$ - recomendação grau llb, nível C.

- $O$ tratamento das crises menstruais não tem indicações específicas, muito embora estas crises costumem ser mais prolongadas e mais intensas que as crises ocorrendo fora do contexto menstrual. Desta forma, sugere-se iniciar a terapêutica com triptanos sendo o triptano ideal aquele que se verifica ser mais eficaz e melhor tolerado em cada doente. Em caso de existir resposta a vários triptanos, sugere-se a utilização de frovatriptano dado que a sua semivida mais prolongada diminui a recorrência em casos de crises longas $^{3}$ - recomendação grau lla, nível C.

\subsection{Contracepção}

- Às mulheres com enxaqueca com aura que pretendem utilizar contraceção é contraindicada a utilização de contraceção hormonal combinada (que inclua etinilestradiol, I7 $\beta$-estradiol/ ou valerato de estradiol) em qualquer forma de apresentação (oral, transdérmica ou anel vaginal) devido ao aumento significativo do risco de $\mathrm{AVC}^{10}$ - recomen- 
dação grau lla, nível C.

- Às mulheres com enxaqueca com aura que pretendem usar contraceção ou que estejam sob contraceção hormonal combinada, assim como às mulheres com enxaqueca sem aura mas com outros fatores de risco vasculares (tabagismo, HTA, obesidade, TVP, TEP e doença cardiovascular prévia) sugere-se a utilização de contraceção não-hormonal (preservativo, DIU cobre ou laqueação de trompas) ou contraceção hormonal progestativa (oral, implante subdérmico, injectável depot, ou DIU com levonorgestrel) por ter baixo risco de $\mathrm{AVC}^{10}$ - recomendação grau I, nível C.

- Nas mulheres com enxaqueca sem aura e sem outros fatores de risco vasculares pode-se considerar a utilização de contraceção hormonal combinada sugerindo-se doses de etinilestradiol $\leq 35 \mu \mathrm{g}$ e a monitorização da frequência e intensidade das crises de enxaqueca e tendo como alternativas a contraceção não-hormonal ou hormonal apenas progestativa $^{10}$ - recomendação grau I, nível C.

- Mulheres sob contraceção hormonal que iniciem queixas de enxaqueca com aura ou sem aura em relação com a toma da contraceção hormonal sugere-se a troca para contraceção não-hormonal ou hormonal apenas progestativa ${ }^{10}$ - recomendação grau lla, nível $\mathrm{C}$.

- Mulheres com enxaqueca (com ou sem aura) que necessitem de contraceção de emergência sugere-se a utilização de levonorgestrel I,5 mg oral, acetato de ulipristal $30 \mathrm{mg}$ oral ou o DIU de cobre ${ }^{10}$ - recomendação grau Ila, nível C.

- Mulheres com enxaqueca (com ou sem aura) que necessitem de contraceção hormonal por síndrome do ovário poliquístico ou endometriose deve-se selecionar o melhor agente caso-a-caso ${ }^{10}$ - recomendação grau II, nível C.

- Mulheres com enxaqueca que estejam medicadas profilaticamente com topiramato devem ser advertidas que este fármaco interfere com a metabolização dos contracetivos hormonais orais, combinados ou progestativos apenas, assim como o impante subcutâneo progestativo, de forma muito relevante em doses superiores a $200 \mathrm{mg} / \mathrm{dia}$ mas também apresentam alguma interferência em doses até $100 \mathrm{mg} / \mathrm{dia}^{2}$ - recomendação grau I, Nível C (boa prática clínica).
- Às mulheres com enxaqueca que estejam medicadas com topiramato e utilizem contracetivos hormonais orais devem utilizar medidas contracetivos adicionais, tais como métodos de barreira ou aumento da dose de estradiol (até $50 \mu \mathrm{g}$ ) ou deve-se sugerir alterar contraceção hormonal para medroxiprogesterona depot ou DIU com levonorgestrel ou para métodos não hormonais ${ }^{2}$ - recomendação grau II, nível C - Os novos anticorpos monoclonais anti-CGRP ou rCGRP não tem evidência de influenciar a fertilidade, no entanto os dados existentes são limitados. ${ }^{1-13}$ Deve-se recomendar às mulheres com enxaqueca que utilizem estes fármacos que mantenham medidas eficientes de contraceção - recomendação grau I, nível C.

\subsection{Pré-conceção}

- A medicação preventiva da enxaqueca com $\beta$-bloqueantes, antiepiléticos, bloqueadores dos canais de cálcio, IECAs e antidepressivos deve ser descontinuada quando a doente decide começar a tentar conceber ${ }^{14,15}$ - recomendação grau I, nível C. - A utilização contínua de AINEs (quer como profilaxia, quer em contexto de cefaleia por uso excessivo de medicação) na fase pré e periconcepcional pode interferir com a ovulação e implantação, reduzindo a fertilidade ${ }^{15}$ - recomendação grau Ilb, nível C.

- O valproato de sódio é contraindicado na mulher em idade fértil e, sobretudo, na fase pré-conceção ${ }^{16}$ - recomendação grau I, nível B.

- As doentes que façam antiepiléticos como profiláticos da enxaqueca devem receber suplementação de ácido fólico numa dose mínima de $4 \mathrm{mg}$ por dia pré-conceção de forma a reduzir o risco de defeitos do tubo neural e outras potenciais anomalias fetais $^{14,17}$ - recomendação grau lla, nível B.

- A profilaxia da enxaqueca na fase da conceção deve ser sobretudo não-farmacológica (biofeedback, gestão do stress, hidratação, redução da atividade laboral, relaxamento muscular, correcção postural, higiene do sono, repouso) ${ }^{1,15,16}$ ou, se não for possível um adequado controle de sintomas neste contexto, devem ser utilizados os agentes considerados mais seguros, em monoterapia e na dose mínima considerada eficaz, sempre discutindo os riscos de cada medicação com a doente ${ }^{14}$ - recomendação grau lla, nível C. 
- Os agentes ergotamínicos são classificados como categoria $X$ (existe risco definitivo baseado na experiência humana ou em estudos animais e os riscos prevalecem sobre os benefícios da grávida) dado possuírem efeitos simpaticomiméticos vasoconstritores arteriais generalizados, com diminuição da perfusão uterina e aumento da contratilidade uterina, tendo inclusivamente sido utilizados como abortivos no passado. Assim, são os únicos fármacos do tratamento agudo da enxaqueca formalmente contraindicados na mulher em idade fértil e, sobretudo, na fase pré-conceção ${ }^{14,16}$ - recomendação grau III, nível C.

- O Feverfew (Tanacetum parthenium L.) ou matricária pode ser utilizado como profilático da enxaqueca, sendo contraindicado na pré-conceção e gravidez por risco de aborto e hemorragia ${ }^{16}$ - recomendação grau III, nível C.

- Os novos anticorpos monoclonais anti-CGRP ou rCGRP não tem evidência de influenciar a fertilidade, no entanto os dados existentes são limitados. ${ }^{11-13}$ É conhecido que este tipo de anticorpos tem a capacidade de transpor a barreira placentária para o feto, pelo que a sua utilização no período pré-concepcional é contraindicada - recomendação grau I, nível C.

\subsection{Gravidez}

- Durante a gravidez $66,9 \%$ das mulheres que sofrem de enxaqueca sem aura (e 68,4\% das com aura) demonstram melhoria ou remissão das manifestações da doença, 25,8\% (e 23,2\% das com aura) mantém as queixas de forma inalterada sendo que $8 \%$ (8,4\% das com aura) agravam; pode-se verificar também uma modificação da expressão da doença, variando o padrão de expressão da doença para um fenótipo menos intenso - enxaqueca com aura manifesta-se sem aura e a enxaqueca sem aura como cefaleia tipo tensão. ${ }^{16}$ Assim, a maioria das mulheres com enxaqueca não necessitará de terapêutica aguda frequentemente nem de profilaxia, durante a gravidez.

- Dos fármacos específicos utilizados no tratamento agudo das crises de enxaqueca, os ergotamínicos são classificados como categoria $\mathrm{X}$, sendo contraindicados na grávida ${ }^{4,15,16}$ - recomendação grau III, nível C. - Os triptanos são classificados como categoria C (es- tudos em animais não indicam risco para o feto e não existem estudos controlados em grávidas, ou não existem estudos animais ou humanos) pelo que se pode considerar a sua utilização se os potenciais benefícios justificarem o risco potencial para o feto, não tendo sido verificados risco fetais nos registos de mulheres que utilizaram triptanos na gravidez. Parece existir um aumento de risco de atonia uterina e hemorragia pós-parto nas mulheres que utilizaram triptanos no final da gravidez. ${ }^{16}$ Deve-se preferir o sumatriptano, dado ser o triptano com mais dados de utilização neste contexto ${ }^{2,4,14-16,18}$ recomendação grau lla, nível B.

- O paracetamol é considerado o analgésico mais seguro para ser utilizado durante a gravidez, sendo a sua formulação oral classificada como categoria B (estudos em animais não demonstraram risco para o feto e não há estudos controlados em grávidas, ou estudos em animais demonstraram um efeito adverso mas estudos controlados em grávidas não demonstraram esse risco) $2,4,15,16,18$ - recomendação grau I, nível C.

- Os AINEs têm o risco de provocar encerramento do ductus arteriosus e hipertensão pulmonar no feto e recém-nascido; assim como oligohidramnios e insuficiência renal neonatal. Existe também suspeita de poderem potenciar o risco de abortos do primeiro trimestre. ${ }^{18}$ São classificados pela FDA como categoria $C$ devendo o seu uso ser limitado no primeiro trimestre e usados apenas até às 32 semanas de gestação e por períodos curtos se os potenciais benefícios justificarem o risco potencial para o feto ${ }^{2,4,14-16}$ - recomendação grau I, nível C.

- Os antieméticos como a metoclopramida e o ondansetron são classificados como categoria B (estudos em animais não demonstraram risco para o feto e não há estudos controlados em grávidas, ou estudos em animais demonstraram um efeito adverso mas estudos controlados em grávidas não demonstraram esse risco) podendo ser utilizados na gravidez em contexto de tratamento das crises de enxaque$\mathrm{ca}^{2,4,14-16,18}$ - recomendação grau I, nível C. No entanto, existem alguns dados contraditórios sobre a possibilidade do ondansetron, quando utilizado para tratar as náuseas associadas à gravidez, poder apresentar um pequeno aumento de risco de defeito do septo cardíaco e de fenda do palato. ${ }^{19}$ A domperido- 
na pode ser considerada alternativa à metoclopramida, no entanto há relatos de prolongamento do QT no recém-nascido. ${ }^{15,18} \mathrm{~A}$ utilização de codeína ou tramadol é desaconselhada, no geral, no tratamento das crises de enxaqueca, sendo considerados de categoria $C$ na gravidez podendo ser utilizados com precaução, pontualmente, em doses baixas dado os riscos de hemorragia pós-parto, depressão respiratória e/ou síndrome de abstinência do recém-nascido $\mathrm{e}^{1,15,16}$ - recomendação grau Ilb, nível C).

- Em casos de estado de mal de enxaqueca ou crises prolongadas e refratárias, pode ser considerada a utilização de bloqueios anestésicos do occipital com lidocaína (classificada como categoria B), ${ }^{2}$ corticoides parentéricos - idealmente a metilprednisolona (classificada como categoria C) e evitando o primeiro trimestre - ou o sulfato de magnésio (categoria D) ${ }^{15,16,18}$ - recomendação grau Ilb, nível C.

- Dos fármacos utilizados como profiláticos da enxaqueca, os antiepiléticos - em particular o valproato de sódio - são classificados como categoria D (existe a evidência de risco fetal humano, mas existem situações em que os benefícios podem prevalecer em relação ao risco). No entanto, no caso da enxaqueca, o benefício não é superior ao risco, pelo que se contraindicada a sua utilização na gravidez ${ }^{4,14-16}$ - recomendação grau III, nível C. A lamotrigina é considerada segura na gravidez, podendo ser utilizada se for necessário o tratamento profilático da aura $^{18}$ - recomendação grau II, nível C.

- Os $\beta$-bloqueantes são classificados como categoria $C$ pelo que se pode considerar a sua utilização tendo em consideração o risco de atraso de crescimento intrauterino e bradicardia fetal ${ }^{14}$ recomendação grau II, nível C. O propranolol e o metoprolol são, assim, os fármacos de eleição como profiláticos da enxaqueca na gravidez, devendo ser utilizados na menor dose possível, durante o menor tempo possível e com monitorização do crescimento uterino e da frequência cardíaca fetal ${ }^{2,4,15,16,18}$ - recomendação grau Ila, nível C.

- A amitriptilina, a flunarizina e a toxina botulínica são classificadas como categoria $\mathrm{C}$, sendo a amitriptilina em dose baixa a segunda opção durante a gravidez e a toxina reservada para casos refratários ${ }^{15,16,18}$ recomendação grau II, nível C.

- Os antihipertensores lisinopril e candesartan são classificados como categoria D por apresentarem risco de malformações graves e morte fetal, pelo que são contraindicados na gravidez ${ }^{15,16,18}$ - recomendação grau II, nível C.

- A neuroestimulação não invasiva com estimuladores do trigémeo, vago e estimulação magnética transcraniana não parecem ter riscos teóricos na gravidez, no entanto a evidência de segurança é limitada a casos pontuais pelo que a sua utilização pode ser considerada, mas não é recomendada ${ }^{2}-$ recomendação grau Ilb, nível C.

- Os novos anticorpos monoclonais anti-CGRP ou rCGRP foram testados na gravidez apenas em modelos animais não se tendo verificado evidência de toxicidade fetal ou de transferência placentária. ${ }^{\mid 1-13}$ É conhecido que este tipo de anticorpos tem a capacidade de transpor a barreira placentária para o feto, pelo que a sua utilização na gravidez é contraindicada - recomendação grau I, nível C.

\subsection{Aleitamento}

- Na fase pós-parto pode ocorrer agravamento das enxaquecas, em relação à fase da gravidez. Sendo frequente que as mães decidam amamentar os seus filhos, coloca-se a questão de que fármacos são seguros neste contexto; no entanto apenas $43 \%$ das mulheres que decidem amamentar tem recorrência das crises na fase pós-parto, em contraste com $100 \%$ das mulheres que decide não amamentar. ${ }^{20}$ As mulheres que amamentam podem manter benefício. Alguns aspetos farmacocinéticos influenciam o risco de iatrogenia, devendo-se ter em consideração na escolha destes fármacos a probabilidade de passagem para o leite materno (menor nos compostos de elevado peso molecular) e a segurança para o recém-nascido e o momento de administração à mãe, de forma a minimizar a exposição do bebél - recomendação grau I, nível C.

- O paracetamol e o ibuprofeno são considerados os fármacos mais seguros durante 0 aleitamento materno $2,4,15,16,18,21$ - em particular o ibuprofeno tem muito baixa dose infantil relativa (índice entre a dose infantil e dose materna, considerado seguro abaixo dos $10 \%)^{\prime}$ - pelo que são a primeira linha na terapêutica das crises durante o aleitamento recomendação grau I, nível B.

- Os AINEs de um modo geral são considerados 
fármacos seguros durante 0 aleitamento materno $2,4,15,16,18$; o diclofenac e ceterolac são provavelmente compatíveis com o aleitamento, não existindo casos descritos de efeitos no recém-nascido, a indometacina e naproxeno utilizados de forma esporádica também, no entanto existem alguns casos de complicações descritas com estes fármacos. A aspirina é potencialmente tóxica, devendo ser evitada, por risco de síndrome de Reye e efeitos plaquetários $^{15,21}$ - recomendação grau lla, nível C.

- Os ergotamínicos são contraindicados durante o aleitamento, por interferência com a produção de prolactina e risco de ergotismo e convulsões no recém-nascido',4,15,16,21 - recomendação grau III, nível C.

- Existe evidência publicada de segurança sobre o sumatriptano no recém-nascido e evidência que o sumatriptano e o eletriptano são excretados em níveis muito baixos no leite materno. ${ }^{16}$ Muito embora não existam dados sobre os restantes triptanos, são todos considerados compatíveis com a amamentação, ${ }^{4,15,21}$ embora algumas recomendações sugiram evitar o aleitamento nas 24 horas após a sua toma ${ }^{16}$ e/ou evitar os triptanos com maior semivida ${ }^{15}$ - recomendação grau Ila, nível C.

- Os antiemeticos e neuroléticos de um modo geral são considerados potencialmente tóxicos e devem ser evitados, à excepção do ondansetron, que é considerado potencialmente compatível com o aleitamento $^{4,16,21}$ - recomendação grau llb, nível C.

- A codeína e os opioides são potencialmente tóxicos sobretudo nos prematuros, devendo ser evitados, ${ }^{15}$ mas a cafeina, lidocaína e predisolona são consideradas compatíveis e seguras durante a amamentação ${ }^{16,21}$ - recomendação grau lla, nível C.

- Dos profiláticos da enxaqueca são considerados seguros durante o aleitamento os $\beta$-bloqueantes (propranolol e metoprolol), tendo muito baixa dose infantil relativa, devendo-se vigiar o risco de hipoglicémia, bradicardia e sonolência no recém-nascido

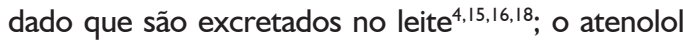
e o nadolol são potencialmente tóxicos devendo ser evitados $^{21}$ - recomendação grau lla, nível C.

- Outros fármacos que podem ser utilizados são a amitriptilina (vigiando o risco de sonolência e retenção urinária no recém-nascido) dado que é excretado no leite mas não apresenta evidência de toxicidade no recém-nascido, ${ }^{4,15,21}$ o magnésio que é considerado compatível com o aleitamento (vigiando o risco de diarreia no recém-nascido) e a toxina botulínica, que não é excretada no leite materno ${ }^{15,16,18,21}$ - recomendação grau Ilb, nível C.

- Os antiepiléticos valproato de sódio, topiramato e lamotrigina podem ser considerados durante o aleitamento, embora haja evidência de toxicidade ${ }^{21}$ pelo que se recomenda precaução e monitorização clinica e laboratorial do recém-nascido, nomeadamente de sedação, irritabilidade e hepatotoxicidade $e^{4,15,16,18}$ - recomendação grau II, nível C. Destes, o topiramato é o único com dose infantil relativa na faixa do inseguro, sendo o valproato o que apresenta menor.'

- Os antihipertensores lisinopril e candesartan podem ser considerados durante o aleitamento, embora haja evidência de toxicidade, ${ }^{21}$ pelo que se recomende precaução e monitorização clinica e laboratorial do recém-nascido, pois pode provocar hipotensão e toxicidade renal ${ }^{15,16,18}$ - recomendação grau II, nível C.

- A flunarizina é contraindicada durante o aleitamento materno dado que provoca sedação e efeitos cardiovasculares no recém-nascido ${ }^{15,16,18}$ - recomendação grau II, nível C.

- Desconhecem-se se os efeitos dos novos anticorpos monoclonais anti-CGRP ou rCGRP nos recém-nascidos ${ }^{11-13}$ no entanto é conhecido que este tipo de anticorpos tem a capacidade de ser excretado no leite materno, pelo que a sua utilização no período de amamentação é contraindicada - recomendação grau I, nível C.

\subsection{Menopausa}

- O período perimenopausa está relacionado com flutuação dos níveis hormonais e consequente aumento da frequência das crises de enxaqueca que, uns anos após a instalação da menopausa, geralmente diminui significativamente.

- Não há contraindicação para a instituição de TSH nas mulheres com enxaqueca com ou sem aura ${ }^{2}-$ recomendação grau Ila, nível $\mathrm{C}$.

- Pode-se considerar a utilização de venlafaxina (75 a $150 \mathrm{mg}$ ), escitalopram ( $10 \mathrm{a} 20 \mathrm{mg}$ ) ou paroxetina (20 a $40 \mathrm{mg}$ ) no tratamento dos sintomas de privação hormonal (incluindo o aumento de frequência de enxaqueca) nas mulheres com contraindicações para 
realizarem THS 2,4 - recomendação grau llb, nível C.

- O tratamento da enxaqueca na fase perimenopausa é idêntico à terapêutica da enxaqueca em geral ${ }^{4}$ recomendação grau Ila, nível C.

\section{Cefaleia Tipo Tensão}

- Em mulheres com cefaleias (não enxaqueca) pode ser considerada a utilização de qualquer método contracetivo, incluindo a contraceção hormonal combinada com baixa dose de estrogénios ${ }^{10}-$ recomendação grau Ila, nível C.

- Durante a gravidez $82,5 \%$ das mulheres que sofrem de cefaleias de tensão demonstram melhoria ou remissão das manifestações da doença e 17,9\% mantém as queixas de forma inalterada, não sendo habitual o agravamento. ${ }^{16}$

- Tal como na enxaqueca (ver acima), para a terapêutica de crise, o paracetamol é considerado o analgésico mais seguro durante a gravidez ${ }^{16,18}$ - recomendação grau I, nível B, podendo ser considerada a utilização de AINEs até às 32 semanas de gestação e por períodos curtos se os potenciais benefícios justificarem o risco potencial para o feto ${ }^{14}$ - recomendação grau I, nível C. Quer o paracetamol quer os AINEs são considerados seguros durante o aleitamento materno ${ }^{16,18}$ - recomendação grau II, nível B.

- Como profilático, a amitriptilina é considerada segura na gravidez (categoria C) e aleitamento (vigiando o risco de sonolência e retenção urinária no recém-nascido) ${ }^{16,18}$ - recomendação grau II, nível C.

\section{Cefaleias trigémino-autonómicas}

- Em mulheres com cefaleias (não enxaqueca) pode ser considerada a utilização de qualquer método contracetivo, incluindo a contraceção hormonal combinada com baixa dose de estrogénios ${ }^{10}-$ recomendação grau Ila, nível C.

- Durante a gravidez 69,9\% das mulheres que sofrem de cefaleias em salvas demonstram melhoria ou remissão das manifestações da doença e 20,7\% mantém as queixas de forma inalterada e $9,4 \%$ agravam. ${ }^{16}$

- As estratégias terapêuticas não farmacológicas devem ser privilegiadas no tratamento da cefaleia em salvas na gravidez e aleitamento, tais como suspensão de consumo de tabaco e álcool e utilização de CPAP em caso de SAOS associado ${ }^{22}$ - recomendação grau I, nível C.

- A terapêutica da crise de cefaleia em salvas duran- te a gravidez e aleitamento pode ser efetuada com recurso a oxigenoterapia de alto débito ou com sumatriptano 14,18,22 - recomendação grau lla, nível B.

- Para terapêutica de ponte ou de transição na cefaleia em salvas na gravidez ou aleitamento, pode ser considerada a utilização de bloqueios anestésicos do occipital com lidocaína (classificada como categoria B) ou corticoides (prednisolona ou metilprednisolona, categoria C) e evitando o primeiro trimestre ${ }^{16,18,22}$ - recomendação grau lla, nível C.

- O verapamilo é classificado como categoria C, acarretando risco de bradicardia fetal, mas é a melhor opção para o tratamento da cefaleia em salvas na gravidez. Quando usada no último trimestre de gravidez aumenta o risco de parto prematuro, sendo considerado seguro durante o aleitamento materno $^{16,18,21,22}$ - grau de recomendação II, nível C.

- A melatonina não tem classificação da FDA por se tratar de um suplemento, mas um estudo em animais documentou efeito deletério no peso materno e fetal assim como na mortalidade fetal, pelo que desaconselha na gravidez. ${ }^{23}$ É, no entanto, considerada segura durante o aleitamento materno, embora possa provocar sonolência no recém-nascido ${ }^{16,18}$ - grau de recomendação Ilb, nível C.

- O carbonato de lítio pode afetar a fertilidade, gestação e desenvolvimento fetal, nomeadamente com risco de malformações cardíacas e outras, sendo classificado como categoria $D$ e contraindicado na gravidez e pré-conceção. Está igualmente contraindicado no aleitamento, dado o risco de alterações renais e tiroideias no recém nascido ${ }^{16,18}$ - grau de recomendação III, nível B.

- Os antiepiléticos valproato de sódio e topiramato são contraindicados na gravidez mas podem ser utilizados durante o aleitamento, embora se recomende precaução e monitorização clinica e laboratorial do recém-nascido, pois podem provocar sedação, irritabilidade e hepatotoxicidade ${ }^{16,18,22}$ recomendação grau II, nível C.

- A lamotrigina é considerada segura na gravidez e aleitamento, podendo ser utilizada se for necessário o tratamento do SUNCT ${ }^{16,18}$ - recomendação grau II, nível $\mathrm{C}$.

- A indometacina pode ser utilizada apenas no segundo trimestre da gravidez no tratamento da hemicrania paroxística ${ }^{18}$ - recomendação grau II, nível C. 


\section{Nevralgias cranianas}

- Em mulheres com cefaleias (não enxaqueca) pode ser considerada a utilização de qualquer método contracetivo, incluindo a contraceção hormonal combinada com baixa dose de estrogénios ${ }^{10}$ - recomendação grau lla, nível C.

- Os opioides (tramadol e codeína) podem ser utlizados com precaução durante a gravidez (categoria C) e o aleitamento, tendo risco de sonolência e depressão respiratória no recém-nascido ${ }^{18}$ - recomendação grau II, nível C.

- A carbamazepina é classificada pela FDA como categoria $D$ (existe a evidência de risco fetal humano, mas existem situações em que os benefícios podem prevalecer em relação ao risco), sendo que no contexto da nevralgia do trigémeo é raro o benefício ser maior que o risco e, quando é assim considerado, deve ser utilizada a menor dose possível, em monoterapia, durante o menor período de tempo possível e idealmente evitando o período de organogénese entre as $4 \mathrm{e}$ as 10 semanas de gestação (recomendação grau lla, nível C). ${ }^{24} \mathrm{~A}$ carbamazepina pode ser utilizada durante o aleitamento, embora se recomende precaução e monitorização clinica e laboratorial do recém-nascido, pois pode provocar sedação e hepatotoxicidade ${ }^{18}$ - recomendação grau II, nível C.

- A oxcarbamazepina, lamotrigina e pregabalina podem ser utilizadas como alternativas à carbamazepina, sendo consideradas como categoria $C$ (estudos em animais não indicam risco para o feto e não existem estudos controlados em grávidas, ou não existem estudos animais ou humanos) (recomendação grau II, nível C). ${ }^{24} \mathrm{~A}$ pregabalina está contra-indicada no aleitamento, por ausência de dados de segurança $^{18}$ - grau de recomendação llb, nível C, enquanto que a lamotrigina é considerada segura na gravidez e aleitamento ${ }^{16,18}$ (recomendação grau II, nível C).

- A toxina onabotulínica tipo $A$ também é categoria $C$ (estudos em animais não indicam risco para o feto e não existem estudos controlados em grávidas, ou não existem estudos animais ou humanos) no entanto pode ser considerada, se o benefício for considerado ser superior ao risco (recomendação grau II, nível C). ${ }^{24}$ Uma alternativa segura, sobretudo no primeiro trimestre da gravidez, é a realização de bloqueios anestésicos com lidocaína (categoria B - recomendação grau lla, nível C). ${ }^{24}$

\section{RESUMO DAS ORIENTAÇÕES TERAPÊUTICAS}

- Em mulheres com cefaleias (não enxaqueca) pode ser considerada a utilização de qualquer método contracetivo, incluindo a contraceção hormonal cominada com baixa dose de estrogénios ${ }^{10}-$ recomendação grau lla, nível C.

- Mulheres com enxaqueca sem aura e sem outros fatores de risco vasculares pode-se considerar a utilização de contraceção hormonal combinada sugerindo-se doses de etinilestradiol $\leq 35 \mu \mathrm{g}$ e a monitorização da frequência e intensidade das crises de enxaqueca e tendo como alternativas preferenciais a contraceção não-hormonal ou hormonal apenas progestativa - recomendação grau I, nível C.

- Mulheres com enxaqueca com aura ou mulheres com enxaqueca sem aura mas com outros factores de risco vasculares (tabagismo, HTA, obesidade, TVP, TEP e doença cardiovascular prévia) sugere-se a utilização de contraceção não-hormonal (preservativo, DIU cobre ou laqueação de trompas) ou contraceção hormonal progestativa (oral, implante subdérmico, injectável depot, ou DIU com levonorgestrel) - recomendação grau I, nível C.

- Durante a gravidez, a maioria das mulheres não necessita de terapêutica preventiva para a enxaqueca ou para outras cefaleias, necessitando pontualmente (e, sobretudo, durante o primeiro trimestre) de terapêutica aguda - recomendação grau I, nível C (boa prática clínica).

- A ergotamina, os antiepiléticos (em particular o valproato de sódio), o carbonato de lítio, a matricária e os anticorpos monoclonais anti CGRP / rCGRP estão formalmente contraindicados na fase préconceção e durante a gravidez, pelo seu documentado potencial abortivo e teratogénico e também no aleitamento - recomendação grau III, nível C.

- O paracetamol (eventualmente associado a metoclopramida) são os fármacos considerados mais seguros para utilização no tratamento agudo das crises simples de enxaqueca e de cefaleia tipo tensão durante a gravidez- recomendação grau I, nível B; em caso de falência terapêutica poder-se-á con- 
siderar a utilização de AINEs (até às 32 semanas), codeína ou tramadol em doses baixas (que se podem utilizar em casos de nervalgias cranianas) ou triptanos, em particular o sumatriptano, que pode também ser utilizado na cefaleia em salvas - recomendação grau lla, nível C.

- Os $\beta$-bloqueantes (propranolol e metoprolol) são a primeira linha de terapêutica preventiva farmacológica da enxaqueca na gravidez e aleitamento, sendo a amitriptilina em doses baixas considerada a segunda linha em termos de segurança, podendo também ser utilizada em casos de cefaleia tipo tensão - recomendação grau lla, nível C.

- O aleitamento materno parece proteger da recorrência da enxaqueca no período pós-parto; durante o aleitamento materno, o paracetamol e o ibuprofeno são considerados os fármacos mais seguros para tratamento agudo das crises de enxaqueca e de cefaleia tipo tensão - recomendação grau I, nível B.

- Os profiláticos da enxaqueca mais seguros durante o aleitamento são os $\beta$-bloqueantes (propranolol e metoprolol apenas), devendo-se vigiar o risco de hipoglicémia, bradicardia e sonolência no recém-nascido; - recomendação grau lla, nível C - como opção pode-se utilizar a amitriptilina (vigiando o risco de sonolência e retenção urinária no recém-nascido), o magnésio (vigiando o risco de diarreia no recém-nascido) e a toxina botulínica - recomendação grau llb, nível C.

- Nos casos de cefaleia em salvas, o oxigénio é considerado o tratamento de eleição das crises na gravidez e aleitamento, sendo o verapamilo o preventivo mais seguro neste contexto - recomendação grau lla, nível C.

- Nos casos de nevralgias cranianas na gravidez e aleitamento, pode-se considerar a utilização de lamotrigina, carbamazepina e opioides, com precaução; como alternativas podem-se considerar a toxina botulínica e a realização de bloqueios anestésicos com lidocaína - grau de recomendação II, nível C.

- Não há contraindicação para a instituição de TSH nas mulheres com enxaqueca com ou sem aura podendo-se relacionar com aumento da frequência das cefaleias - recomendação grau lla, nível C.

\subsection{RECOMENDAÇÕES TERAPÊUTICAS PARA CEALEIAS EM DOENTES IDOSOS E COM MÚLTIPLAS COMORBILIDADES}

\section{a) Considerações gerais}

A abordagem da cefaleia nos idosos é diferente devido ao aumento de frequência de cefaleias secundárias, doenças comórbidas e possível polifarmácia.' Embora as cefaleias mais prevalentes nos idosos continuem a ser as cefaleias primárias como a cefaleia tipo tensão e a enxaqueca, uma cefaleia de novo nesta faixa etária obriga a avaliação diagnóstica para exclusão de causas secun-

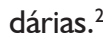

As comorbilidades aumentam o risco de cefaleia secundária e trazem tanto limitações como oportunidades quanto às escolhas terapêuticas. ${ }^{3}$ Algumas, como a doença osteoarticular e musculoesquelética aumentam o uso de medicação analgésica. ${ }^{4}$ Alterações nas funções renal e hepática podem alterar a farmacocinética e reduzir a tolerabilidade à medicação.'

Os fármacos recomendados para o tratamento têm habitualmente eficácia semelhante na população mais idosa.' Devido às contraindicações frequentes dos fármacos sintomáticos, os tratamentos preventivos e não farmacológicos assumem especial importância no idoso com cefaleias frequentes. ${ }^{3}$ É especialmente importante nesta população começar com doses baixas de medicação e fazer uma titulação lenta. Cada preventivo deve ser titulado, otimizado e levado até à dose máxima alvo antes de ser adicionada outra medicação ou ser substituído (preferível, de forma a evitar a polifarmácia ${ }^{2}$ ).Adicionalmente, os tratamentos não farmacológicos devem ser sempre otimizados para prevenir polifarmácia e sobreutilização de medicamentos. ${ }^{2}$

Nesta faixa etária há uma prevalência aumentada de patologia do espectro depressão-ansiedade e dor crónica, e aumento do risco cardiovascular e respiratório. Estes devem ser vigiados, diagnosticados e abordados de forma apropriada e eficaz, de forma a melhorar o prognóstico final.'

\section{b) Considerações terapêuticas}

Entre os medicamentos sintomáticos frequentemente usados no tratamento de cefaleias, alguns que exigem considerações especiais nesta população são (grau I, nível de evidência C):

- Anti-inflamatórios não esteróides - Os idosos apre- 
sentam uma frequência maior de reações adversas, pelo que devem ser utilizados com precaução e estão contraindicados em caso de doença renal, gastrointestinal ou cardíaca, dependendo da gravidade da mesma. ${ }^{2}$ Numa meta-análise o naproxeno demonstrou ter menor risco cardiovascular. ${ }^{5}$ As contraindicações incluem também história de alergia ou diátese hemorrágica e devem ser evitados em caso de tratamento concomitante com corticosteroides e varfarina. ${ }^{3}$

- Derivados da ergotamina - Estão contraindicados em caso de doença isquémica, devido às suas propriedades vasoconstritoras. $^{2}$

- Triptanos - Permanecem como escolha de primeira linha, mesmo nos idosos, desde que sem risco cardiovascular aumentado. ${ }^{2} \mathrm{O}$ risco cardiovascular pode ser avaliado com base nos resultados do estudo de Framingham, encontrando-se uma calculadora de risco em http://www.cardiology.org/tools/medcalc.fram/. Nos doentes de risco baixo, os triptanos podem ser usados com segurança relativa. No grupo de alto risco devem ser evitados, enquanto que no grupo intermédio devem ser realizados EGC e prova de esforço antes da sua prescrição. ${ }^{6}$

As medicações contendo combinações de analgésicos, opióides e barbitúricos estão associadas a maior risco de abuso, dependência, cefaleia por uso excessivo de medicamentos, polifarmácia e efeitos adversos. Não devem ser usados no tratamento de rotina em idosos e devem ser limitados a quando outras medicações estão contraindicadas. $^{2}$

Dos medicamentos profiláticos frequentemente usados na prevenção de cefaleias, alguns que apresentam considerações especiais nesta população são (grau I, nível de evidência $C$ ):

- Amitriptilina - São recomendadas doses mais baixas, de $50 \mathrm{mg}$. Deve ser administrada com precaução em doentes com história de crises convulsivas, com perturbações da função hepática, história de retenção urinária, hipertrofia prostática, glaucoma de ângulo fechado ou hipertensão intraocular. Os doentes com perturbações cardiovasculares devem ser cuidadosamente vigiados dado que a amitriptilina pode provocar arritmias, taquicardia sinusal e alterações da condutibilidade. É necessário efetuar uma monitorização cuidadosa em doentes com hipertiroidismo ou que estão a ser tratados com medicamentos para a tiroide ou com agentes anticolinérgicos. ${ }^{7}$

- Beta-bloqueantes - Devem ser evitados em doentes com insuficiência cardíaca não controlada, e podem causar bradicardia e hipotensão, que em doentes idosos aumenta o risco de síncope e queda. Podem mascarar os sinais de hipoglicémia e tirotoxicose. ${ }^{2,8}$ Podem ocorrer letargia e confusão. Se um beta-bloqueante não for tolerado, outro diferente pode ser. ${ }^{3}$

- Lítio - é frequente ter de se administrar doses de lítio mais baixas para se atingir os níveis séricos terapêuticos, a litemia deve ser medida regularmente, a função renal e tiroideia deve ser monitorizada, a ingestão de líquidos e sódio deve ser adequada. ${ }^{9}$

- Topiramato - Pode ter efeitos secundários cognitivos, incluindo défice de linguagem, inatenção e perda de memória, que nos mais idosos podem ser problemáticos, devido ao medo de défice cognitivo e demência. Outros efeitos adversos incluem parestesias, anorexia, sintomas gastrointestinais, sedação, depressão, acidose metabólica, litíase renal, miopia aguda e glaucoma secundário de ângulo fechado. 2,10 Não é necessário ajuste de dose em doentes idosos desde que a sua função renal esteja intacta. ${ }^{10}$

- Toxina onabotulínica A - É tipicamente bem tolerada por idosos, mas alguns têm ptose senil, que pode ser agravada pelas injeções no terço inferior do músculo frontal. Outra complicação potencial é fraqueza dos músculos cervicais paraespinhais, mais frequente nos idosos devido a fraqueza pré-existente ou atrofia muscular difusa. Esta complicação pode ser evitada ajustando a área das injeções mais superiormente. ${ }^{2}$ Não é necessário um ajuste específico da dose para a utilização em idosos. Os doentes idosos com antecedentes clínicos significativos e medicação concomitante devem ser tratados com precaução. "

- Valproato - Recomenda-se monitorização periódica do hemograma com plaquetas e da função hepática. ${ }^{2}$ Deve-se ter atenção à possibilidade de ocorrência de sonolência, tremor, aumento de peso e alopecia. $^{3}$

- Venlafaxina - Com base apenas na idade não se consideram necessárias alterações específicas da posologia habitual de venlafaxina. Contudo, recomenda-se precaução no tratamento dos idosos (por exemplo, devido à possibilidade de compro- 
misso renal e de alterações potenciais da sensibilidade e afinidade da neurotransmissão que ocorrem com o envelhecimento). Deve utilizar-se sempre a dose efetiva mais baixa e os doentes devem ser cuidadosamente monitorizados quando for necessário efetuar um aumento da dose. ${ }^{12}$

- Verapamilo - Aconselha-se especial precaução e vigilância médica rigorosa em caso de bloqueio auriculoventricular de $1^{\circ}$ grau, bradicardia (<50 pulsações por minuto), hipotensão (pressão sistólica < $90 \mathrm{mmHg}$ ) e insuficiência hepática grave. ${ }^{13}$

\section{c) Cefaleias mais frequentes nos idosos}

A cefaleia hípnica tem como tratamentos preventivos possíveis: lítio (atenção à tolerabilidade), indometacina (atenção à hemorragia gastrointestinal) e cafeína (atenção às complicações cardiovasculares).'

A cefaleia da apneia do sono resolve numa percentagem significativa de doentes tratados com pressão positiva contínua nas vias aéreas. ${ }^{2}$

A cefaleia cardíaca é única por responder à terapêutica com nitroglicerina, fármaco que pode agravar ou desencadear ataques de enxaqueca. ${ }^{2}$ Em todos os casos referidos na literatura a cefaleia resolveu após tratamento ou revascularização da isquemia miocárdica, mas pode recorrer se houver nova estenose. ${ }^{13}$

A cefaleia atribuída a glaucoma agudo de ângulo fechado é tratada eficazmente com iridotomia periférica, que também melhora a pressão intraocular. ${ }^{2}$

\section{INTERAÇÕES FARMACOLÓGICAS NO TRATAMENTO DAS CEFALEIAS}

As interações são bastante frequentes na clínica, mas a maioria não é clinicamente relevante. Acresce que podem ser altamente previsíveis, previsíveis, não previsíveis (ocorrem apenas em alguns dos doentes que recebem a associação de fármacos), havendo ainda algumas para as quais não existem dados que estabeleçam a previsibilidade.

Podem surgir interações entre fármacos usados no tratamento "abortivo" ou sintomático, entre um destes e um fármaco preventivo (embora para a obtenção da AIM tal possibilidade é geralmente bem estudada), entre fármacos usados para o tratamento das cefaleias e fármacos usados para outras patologias, e entre fármacos, alimentos, poluentes e outras substâncias.

As interações medicamentosas podem ser desejadas e não desejadas. Como exemplos das primeiras há o aumento da eficácia de um analgésico ou antiinflamatório pelo uso de um fármaco gastrocinético, como a domperidona ou a metoclopramida, o aumento da segurança, como o uso concomitante de um protetor gástrico e de um AINE, ou o uso simultâneo de antidepressores de primeira geração, como a amitriptilina, e laxantes (para evitar a obstipação); como exemplos das segundas há a diminuição da eficácia pelo uso simultâneo de purgantes e medicamentos para a via oral, e o risco de vasoconstrição exagerada com a associação de dois vasoconstritores (eg, triptano e ergotamina, ou de dois triptanos), o que significa reação adversa.

Os mecanismos das interações podem ser a nível farmacêutico (raros no tratamento das cefaleias, e exemplificado pela incompatibilidade de dois fármacos em solução), a nível farmacocinético (na absorção, distribuição, metabolização e eliminação) e a nível farmacodinâmico. Frequentemente há a combinação de dois ou mais mecanismos. $O$ conhecimento do mecanismo facilita a prevenção e o tratamento das interações não desejadas e o desenho de interações desejadas.

A maioria das interações surgem a nível farmacocinético, no sistema ADME (absorção; distribuição; metabolização; eliminação).

No que respeita à absorção gastrointestinal de fármacos, esta pode ser afetada pelo uso concorrente de outros agentes que:

I. se ligam ou formam quelatos (eg, antiácidos, sucralfato, leite),

2. alteram $\circ \mathrm{pH}$ gástrico (antissecretores de $\mathrm{H}^{+}$, como o omeprazole, o esomeprazole e o lanzoprazole; antiácidos, como os sais de magnésio e/ ou alumínio),

3. alteram a motilidade gastrointestinal (gastrocinéticos, como a domperidona ou a metoclopramida; parassimpaticolíticos, como a butilescopolamina),

4. afetam o transporte por proteínas tais como a P-glicoproteína.

No entanto, há uma grande área para absorção pelo que a extensão da absorção (medida pela área sob a curva (AUC)) será pouco afetada. No entanto, também poderá ser afetada a Cmax e o Tmax (eg, por alimentos ou por modificadores da motilidade gastro-intestinal). Assim, deve distinguir-se entre efeitos na extensão da absorção 
(clinicamente importante) e na rapidez de absorção (raramente importante na clínica). Contudo, a rapidez na absorção é importante para o início de ação de fármacos sintomáticos ou "abortivos" das crises de enxaqueca e poderão surgir níveis subterapêuticos no plasma de analgésicos ou triptanos, com redução do Cmax, induzidos pelos alimentos ou por anticolinérgicos.

Os mecanismos a nível da distribuição incluem:

- competição para as proteínas de ligação no plasma, - deslocamento dos locais de ligação nos tecidos,

- alterações nas barreiras locais nos tecidos (eg, inibição da P-glicoproteína na barreira hemato-encefálica),

- alteração na barreira hemato-encefálica (eg, por algumas drogas, como as anfetaminas).

A competição para as proteínas plasmáticas pode aumentar a forma livre no plasma (e, consequentemente, o efeito) do agente deslocado; o aumento será transitório devido ao aumento compensador na metabolização/ eliminação do fármaco na forma livre, o que significa que a quantidade total no plasma, medida pela AUC, diminui. $\mathrm{Na}$ terapêutica das cefaleias pode acontecer uma interação grave entre anti-inflamatórios não esteroides e a varfarina ou as sulfonilureias, por exemplo, com risco de hemorragia e hipoglicémia, respetivamente.

Por outro lado, o deslocamento dos locais de ligação nos tecidos aumenta transitoriamente a concentração sanguínea do fármaco deslocado.

Todavia, a maioria das interações farmacológicas surgem a nível da metabolização, em fase I, por redução, hidrólise e, principalmente, oxidação, podendo esta última ser independente e dependente do sistema das CYPs, que constituem a maioria das enzimas para oxidação, sendo os polimorfismos mais importantes os que ocorrem nos genes codificadores da CYP2C9, CYP2CI9, e principalmente da CYP2D6 e CYP3A4/5/7. A metabolização por fase II é por conjugação com o ácido glucurónico, com sulfato, acetato, alguns aminoácidos,... A sequência de metabolização é habitualmente fase I e depois fase II, mas pode ser apenas por fase II ou por fase I, ou nem sequer haver metabolização; a metabolização por fase II e depois por fase I é rara, sendo o maior exemplo a acetilação da isoniazida e depois a conjugação do seu metabolito. Um exemplo de fase I e depois fase II é a metabolização do paracetamol, que primeiro dá um metabolito hepatotóxico que terá de se conjugar com o glutatião para ser eliminado. Se não houver glutatião suficiente, por consumo excessivo de álcool ou de medicamentos que também necessitem de glutatião, pode surgir uma hepatite iatrogénica.

No que respeita à CYP2D6, é responsável pela metabolização de $25 \%$ de todos os fármacos, tem 62 alelos distintos, 22 dos quais responsáveis pelo fenótipo metabolizador lento, sendo $35 \%$ da população portadora de, pelo menos, I alelo 2D6 disfuncional. Alguns dos subtratos para a CYP2D6 são os antiarrítmicos (ex: flecainida, propafenona, lidocaina), os antipsicóticos (ex: haloperidol, risperidona), o tamoxifeno e, com particular interesse na terapêutica preventiva da enxaqueca e das tipo tensão os antidepressivos (eg, fluoxetina, paroxetina, venlafaxina, ADT) e na prevenção da enxaqueca os bloqueadores $\beta$ (eg, carvedilol, metoprolol). Os analgésicos opióides (ex: tramadol, codeina), usados muitas vezes no tratamento sintomático, também são substratos desta isoenzima, bem como a morfina. Havendo inibição desta isoforma enzimática por fármacos ou outros agentes, aumentará a concentração do fármaco metabolizado, podendo surgir um evento adverso. Por outro lado, se for um pró-fármaco que necessite da CYP2D6 para se transformar no metabolito ativo, a sua menor expressão ou inibição pode conduzir a ineficácia do pró-fármaco. Um exemplo desta situação é a codeína que tem de ser metabolizada pela CYP2D6 a morfina, a qual evidencia então o respetivo efeito analgésico. De notar que se houver duplicação do gene CYP2D6 poderá surgir intoxicação com a codeína.

No que respeita à CYP3A4, representa $30 \%$ do total de isoenzimas do sistema CYP450, está localizada no fígado, intestino e rim, tem uma expressão duas vezes maior nas mulheres que nos homens. Metaboliza até $50 \%$ de todos os fármacos, incluindo várias classes de fármacos importantes na prática clínica, sendo importante para a absorção, metabolismo sistémico e efeito de primeira passagem. Estão identificados mais de 30 SNP.

Alguns dos substratos da CYP3A4 são antifúngicos (por exemplo, fluconazol, itraconazol, cetoconazol), antihistaminicos, alfentanil, imunosupressores (por exemplo, ciclosporina, tacrolimus), estatinas (eg, sinvastatina), e fármacos importantes no tratamento das cefaleias, tais como bloqueadores dos canais de $\mathrm{Ca}^{++}$(por exemplo, verapamil, diltiazem, felodipina, nifedipina), corticosteroides, anticonvulsivantes (eg, carbamazepina) e antide- 
pressivos (eg, SSRIs).

A inibição ou a indução da CYP3A4, por fármacos ou alimentos (eg, sumo de toranja rosa) pode afetar os fármacos que são por si metabolizados.

De facto, o metabolismo pode ser estimulado ou inibido pela terapêutica concorrente. A indução (estimulação) das CYPs no fígado e intestino delgado pode ser causado por barbitúricos, carbamazepina, efavirenz, nevirapina, fenitoína, rifampicina, rifabutina... Os indutores enzimáticos também podem aumentar a atividade do metabolismo de fase II, como a glucurono-conjugação.

A indução enzimática não tem lugar rapidamente. Os efeitos máximos só ocorrem ao fim de 7-10 dias e necessitam de um tempo igual ou superior para desaparecer depois do indutor enzimático ser suspenso; a rifampicina pode, no entanto, produzir indução após algumas doses.

A inibição enzimática tem lugar rapidamente e pode começar logo que a concentração do inibidor atinja concentração suficiente no tecido. Todavia, se a semivida do fármaco afetado é longa, pode demorar I semana ou mais para atingir um novo nível sérico na fase estacionária.

Fármacos que podem inibir o metabolismo pelas CYPs incluem o alopurinol, a amiodarona, os androgénios, a cimetidina, a ciprofloxacina, a claritromicina, a ciclosporina, a fluoxetina e muitos outros.

No que diz respeito especificamente às cefaleias, as administrações múltiplas habituais de verapamilo, um substrato da CYP3A4 e bloqueador dos canais de cálcio usado na prevenção da enxaqueca e da cefaleia em salvas, poderão levar a um aumento de $20 \%$ na Cmax e AUC do almotriptano. Mas o aumento não foi considerado clinicamente relevante.

Evidentemente que as outras CYPs podem ser clinicamente relevantes, como, por exemplo, a inibição da CYP2C19 pelo omeprazole, interferindo na metabolização da moclobemida, inibidor da MAO-A, e do clopidogrel (um pró-fármaco que tem de originar o metabolito ativo através da ação da CYP2C19).

As interações podem ser também entre fármacos e alimentos/ poluentes. Alguns exemplos:

- O sumo de toranja rosa inibe a CYP3A4, como já foi referido;

- O queijo e derivados contêm tiramina e feniletilamina, que são semelhantes às anfetaminas, e são metabolizadas pela MAO, o que obriga a ter cuida- do com os IMAO (moclobemida (inibidor da MAO$-A)$, selegilina e rasagilina (inibidores da MAO-B) e, principalmente, com os não específicos);

- O etanol é um indutor enzimático;

- O tabaco tem compostos indutores enzimáticos.

Como já foi referido, os alimentos e os parassimpaticolíticos reduzem a Cmax, o que significa que a eficácia dos analgésicos / triptanos pode estar diminuída, já que está associada à Cmax. Os alimentos também podem retardar o tmax, o que pode ter consequências no início de ação de analgésicos ou triptanos no tratamento sintomático.

A nível da excreção ou eliminação renal de fármacos também podem surgir interações. Assim, os fármacos que são ácidos ou bases fracas podem ser influenciados por outros que afetam o $\mathrm{pH}$ urinário por variações na ionização do fármaco. Para alguns fármacos que são segregados de forma ativa nos túbulos renais, a inibição do transportador pode impedir a eliminação renal com consecutivo aumento do nível plasmático desses fármacos (um exemplo deste caso é a inibição pelo probenecide do transportador renal para as anfetaminas e a penicilina).

As interações farmacodinâmicas são relativamente comuns na prática clínica, algumas vezes feitas de modo intencional, mas os efeitos adversos podem ser reduzidos, se for conhecida a farmacologia dos agentes envolvidos, podendo então ser tomadas medidas para os prevenir ou contrariar.

As interações a nível farmacodinâmico, podem surgir a nível dos recetores por antagonismo ou sinergismo (de adição ou de potenciação, neste último caso por inibição da enzima que metaboliza o fármaco, por exemplo), a nível dos processos moleculares consecutivos à ativação do recetor (vias de sinalização) e a nível de sistemas fisiológicos distintos. Assim,

I. Fármacos com ações farmacológicas semelhantes quando administrados concorrentemente podem originar uma resposta sinérgica, de adição ou potenciação. Assim, os dois fármacos podem atuar ou não no mesmo recetor para produzir tais efeitos (eg, triptano com triptano ou com ergotamina, causam mais vasoconstrição e eventualmente isquémia), ou fármacos com o mesmo efeito podem somar ou potenciar tal efeito (eg, alguns AINEs e antiagregantes plaquetares ou ginkgo biloba, no que diz respeito à antiagregação plaquetar; code- 
ína e paracetamol, no controlo da dor; bloqueadores beta e verapamilo, como preventivos da enxaqueca mas também na depressão cardíaca; nimesulida e valproato, quanto à agressão hepática). Mais alguns exemplos estão descritos na Tabela 10.1:

Tabela 10.1. Interações a nível farmacodinâmico, com fármacos usados no tratamentos das cefaleias

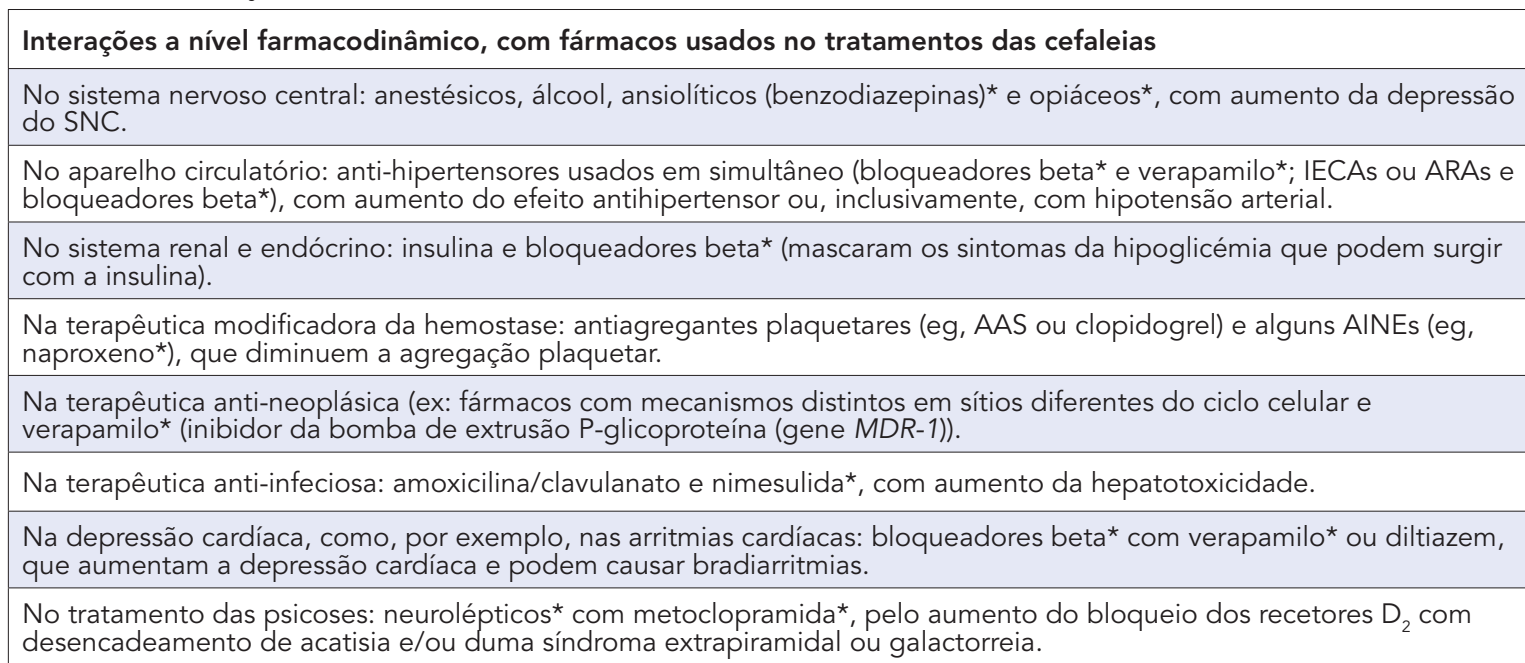

O * assinala o fármaco usado na terapêutica das cefaleias

2. Fármacos com efeitos opostos podem reduzir a resposta de um ou de ambos os fármacos, como, por exemplo, o uso de gastrocinéticos (metoclopramida ou domeridona) com anticolinérgicos (por exemplo, butilescopolamina).

Por outro lado, o uso combinado de 2 ou mais fármacos, cada um com efeitos tóxicos no mesmo órgão, pode aumentar a probabilidade de agressão (toxicidade combinada), como, por exemplo, o uso concorrente de 2 fármacos nefrotóxicos que podem produzir lesão renal mesmo que a dose de ambos isoladamente seja insuficiente para causar danos. Acresce que alguns fármacos podem potenciar a toxicidade de outro, mesmo que o agente potenciador não tenha efeito tóxico intrínseco naquele órgão.

A nível farmacodinâmico a síndroma serotoninérgico merece um maior destaque, já que é com muita frequência subdiagnosticado. $\mathrm{O}$ excesso de $5-\mathrm{HT}$ na fenda sináptica poderá causar esta síndroma grave e potencialmente fatal. É precipitado pela administração de um fármaco serotoninérgico ou, principalmente, pela associação de fármacos modificadores do sistema da 5-HT (inibidores da recaptação da 5-HT ou seja, inibidores seletivos da recaptação neuronal de 5-HT, os SSRls ,como a paroxetina ou a sertralina; ou da inibição da recaptação de 5-HT e noradrenalina, os NaSRI, como a venlafaxina), IMAO (eg, moclobemida), tramadol, sumatriptano, ondansetrom, MDMA, Erva de S. João ou hipericão, LSD e outros. O quadro clínico caracteriza-se por hipertensão arterial, hiperreflexia, tremor, clónus (o sinal mais típico), hipertermia (é uma das síndromes com hipertermia muito elevada), diarreia, midríase, agitação, convulsões e, eventualmente, coma dentro de horas e morte. A terapêutica faz-se com a suspensão dos fármacos suspeitos e com benzodiazepinas, clorpromazina e com a manutenção dos sinais vitais.

Finalmente, no quadro das interações as associações fixas merecem-nos uma atenção mais detalhada. A sua autorização de introdução no mercado (AIM) deveria obedecer à guideline EMA/CHMP/I58268/20I7, que estabelece que uma associação fixa só tem racionalidade farmacológica / terapêutica quando pela associação há aumento da eficácia, da segurança ou da conveniência (facilidade de administração, melhoria da adesão à terapêutica). Achamos que se deve acrescentar o custo. Assim, haverá melhor relação benefício / risco e deveria haver também uma melhor relação de custo / benefício. Uma associação fixa que tenha menor custo, mas à custa de menor eficácia e/ou segurança não é admissível ou justificável (aliás, as regras da Farmacoeconomia do Infarmed não permite a sua comparticipação). 
$\mathrm{Na}$ terapêutica das cefaleias podem surgir as situações seguintes:

I. Adição do fármaco sintomático ou preventivo das cefaleias a uma associação fixa já usada para outra indicação clínica (a maioria é para o tratamento da hipertensão arterial mas existem para muitas outras indicações clínicas - diabetes mellitus do tipo 2, insuficiência cardíaca, etc).

2. Uso da associação fixa para tratamento das cefaleias, como, por exemplo, a codeína com paracetamol, o AAS com o paracetamol, um analgésico com vitamina $C$, um analgésico com cafeína, um AINE com protetor gástrico... De referir que algumas destas associações fixas são questionáveis. Por exemplo, que vantagem haverá na associação de dois analgésicos em dose baixa se podemos ter a mesma eficácia com uma dose mais elevada de um dos analgésicos? Também a vitamina $C$ não acrescenta nada à eficácia dos analgésicos e a cafeína só potencia os analgésicos quando administrada em dose elevada e não na dose da associação fixa. Por outro lado, os protetores gástricos só deveriam ser usados em indivíduos de risco.

Poderá haver vantagem na associação fixa (eventualmente maior eficácia, menos tomas diárias, dose individual mais baixa de um ou dos dois fármacos da associação, eventualmente resultados mais rápidos, melhor tolerabilidade, e, principalmente, maior conveniência ou melhor adesão). Nalguns casos o custo da associação fixa é menor que a soma do custo dos componentes isolados. Porém, também existem desvantagens, como, por exemplo, a perda da flexibilidade na escolha da dose, a dificuldade na titulação da dose, o aumento potencial de reações adversas, com imputação mais difícil (imputado aos dois fármacos?) e a maior possibilidade de interações.

Terá de ser o médico prescritor a decidir tendo em conta as vantagens e desvantagens das associações fixas.

Uma formulação parecida às associações fixas é a “polypill”, que é a associação de vários fármacos com indicações clínicas diferentes na mesma forma farmacêutica, embora contribuindo para um efeito clínico de redução do risco global - por exemplo, a associação de atorvastatina (para reduzir o colesterol-LDL), de AAS (como antiagregante plaquetar) e de ramipril (como antihipertensor arterial). Por enquanto, não temos nenhuma "polypill” para a terapêutica das cefaleias, que como única vantagem terá a melhoria da adesão à terapêutica, tendo a enorme desvantagem das doses fixas.

\section{Conclusão}

As interações são frequentes entre fármacos, ou entre fármacos e outros agentes ou alimentos, como o tabaco e o etanol (indução enzimática). Por prudência, prescrever o menos possível fármacos em associação, exceto se esse é o objetivo, o que acontece com frequência na terapêutica das cefaleias, como, por exemplo, no tratamento das crises de enxaqueca (eg, paracetamol associado à codeína) ou na prevenção das crises de enxaqueca (eg, associação de antidepressores com bloqueadores beta).

Deve-se ter presente que as interações surgem a nível farmacocinético, principalmente a nível da metabolização, nomeadamente a nível das CYPs, e a nível farmacodinâmico. Também podem surgir interações entre fármacos usados na enxaqueca e fármacos usados noutras situações clínicas a nível da distribuição, por exemplo competindo na ligação às proteínas plasmáticas, e a nível da absorção, aumentando-a ou diminuindo-a, através de fármacos que aumentem o esvaziamento gástrico, como a metoclopramida ou a domperidona, ou de fármacos que diminuam esse esvaziamento, como, por exemplo, os parassimpaticolíticos ou anticolinérgicos. Evidentemente que podem surgir interações também a nível da excreção, que, contudo, são muito menos frequentes.

A nível farmacodinâmico, podem surgir interações a nível de recetores, por exemplo pela estimulação de recetores 5-HTIB pelo uso simultâneo (ou sem respeitar um intervalo adequado entre as doses) de triptanos, ou de vias de sinalização, ou através de ações noutros alvos terapêuticos, que conduzam a redução ou aumento do efeito terapêutico.

Na Tabela $\mathbf{1 0 . 2}$ exemplificam-se de modo rápido algumas das interações que podem ocorrer.

As reações adversas causadas pelas interações farmacológicas surgem com frequência (ex., entre depressores cardíacos como os bloqueadores beta e o verapamilo ou o diltiazem), havendo alguma dificuldade na sua imputação. 
Tabela 10.2. Interações farmacológicas.

\begin{tabular}{|c|c|c|}
\hline \multicolumn{3}{|l|}{ A nível farmacocinético } \\
\hline \multicolumn{3}{|l|}{ Absorção } \\
\hline Gastrocinéticos* & Analgésico / AINE & Aumento da absorção do analgésico/AINE \\
\hline Anticolinérgicos & Analgésico / AINE & Diminuição da absorção do analgésico/AINE \\
\hline \multicolumn{3}{|l|}{ Distribuição } \\
\hline AINEs & Sulfonilureias & Hipoglicémia \\
\hline AINEs & Varfarina & Hemorragia \\
\hline \multicolumn{3}{|l|}{ Metabolização } \\
\hline Macrólidos & Ergotamina & Inibição do metabolismo da ergotamina \\
\hline IMAO A e B & Ergotamina & Inibição do metabolismo da ergotamina \\
\hline Propranolol & Rizatriptano & Aumento dos níveis sanguíneos do rizatritptano \\
\hline IMAO A e B & Antidepressivos & Aumento do efeito do IMAO e antidepressivos \\
\hline IMAO A e B & $\begin{array}{l}\text { Triptanos (rizatriptano, sumatriptano, } \\
\text { zolmitriptano) }\end{array}$ & Diminuição do metabolismo dos triptanos \\
\hline Cimetidina & Zolmitriptano & $\begin{array}{l}\text { Aumento dos níveis de zolmitriptano por inibição } \\
\text { da CYP1A2 }\end{array}$ \\
\hline Claritromicina, itraconazol & Eletriptano & $\begin{array}{l}\text { Aumento dos níveis de eletriptano por inibição } \\
\text { da CYP3A4 }\end{array}$ \\
\hline Rifampicina & Anovulatórios hormonais & $\begin{array}{l}\text { Indução enzimática (perda de eficácia dos } \\
\text { anovulatórios) }\end{array}$ \\
\hline \multicolumn{3}{|l|}{ Excreção } \\
\hline Lítio & Diuréticos & Retenção e potenciação do lítio \\
\hline Verapamilo & Digoxina & Retenção da digoxina \\
\hline \multicolumn{3}{|l|}{ A nível farmacodinâmico } \\
\hline $\begin{array}{l}\text { Ansiolíticos } \\
\text { (benzodiazepinas) }\end{array}$ & Etanol & Maior depressão do SNC \\
\hline Bloqueadores beta & Ergotamina & Vasoconstrição excessiva \\
\hline Bloqueadores beta & Verapamilo / diltiazem & Aumento da depressão cardíaca \\
\hline Metoclopramida & Neurolépticos & Aumento do bloqueio D2 (ações extrapiramidais) \\
\hline $\begin{array}{l}\text { Metoclopramida / } \\
\text { domperidona }\end{array}$ & Anticolinérgicos & $\begin{array}{l}\text { Inibição dos efeitos gastrocinéticos da } \\
\text { metoclopramida ou da domperidona }\end{array}$ \\
\hline Clavulanato & Valproato & Hepatotoxicidade \\
\hline $\begin{array}{l}\text { Diuréticos de ansa (eg, } \\
\text { furosemido) }\end{array}$ & Aminoglicosídeos (eg, gentamicina) & Nefrotoxicidade \\
\hline Triptanos & Ergotamina ou DHE\# & Vasoconstrição excessiva \\
\hline
\end{tabular}

*Gastrocinéticos: metoclopramida ou domperidona; \# DHE: dihidroergotamina 


\section{SIGLAS E ABREVIATURAS}

\begin{tabular}{|c|c|}
\hline $5-\mathrm{HT}$ & 5-hidroxitriptamina \\
\hline AAS & ácido acetilsalicílico \\
\hline AVC & acidente vascular cerebral \\
\hline $\mathrm{AE}$ & antiepileptico \\
\hline AHS & $\begin{array}{l}\text { American Headache Society (Sociedade } \\
\text { Americana de Cefaleias) }\end{array}$ \\
\hline AIM & autorização de introdução no mercado \\
\hline AINEs & anti-inflamatórios não esteroides \\
\hline ARA & antagonistas dos recetores da angiotensina \\
\hline AVC & acidente vascular cerebral \\
\hline \multirow[t]{2}{*}{ Amc-CGRP } & anticorpos monoclonais dirigidos ao CGRP \\
\hline & ou ao receptor (Amc-rCGRP) \\
\hline BoNTA & onabotulinumtoxin $\mathrm{A}$ \\
\hline CAM & cefaleia de abuso medicamentoso \\
\hline CTT & cefaleia tipo tensão \\
\hline \multirow[t]{2}{*}{ CGRP } & (calcitonin gene related peptide) - peptido \\
\hline & relacionado com o gene da calcitonina \\
\hline DGS & Direção Geral de Saúde \\
\hline $\mathrm{DM}$ & desvio médio \\
\hline EAM & enfarte agudo do miocárdio \\
\hline EC & enxaqueca crónica \\
\hline EE & enxaqueca episódica \\
\hline \multirow[t]{2}{*}{$\mathrm{EHF}$} & European Headache Federation (Federação \\
\hline & Europeia de Cefaleias) \\
\hline
\end{tabular}

ERCP ensaios randomizados e controlados com placebo

$\begin{array}{ll}\text { EUA } & \text { Estados Unidos da América } \\ \text { FC } & \text { frequência cardíaca } \\ \text { FDA } & \text { Food and Drug Administration } \\ \text { HC } & \text { hemicrânia continua } \\ \text { HP } & \text { hemicrânia paroxística } \\ \text { HTA } & \text { hipertensão arterial } \\ \text { IC } & \text { intervalo de confiança } \\ \text { IECA } & \text { inibidor da enzima de conversão da } \\ & \text { angiotensina } \\ \text { Ig } & \text { Imunoglobulina } \\ \text { IHS } & \text { International Headache Society (Sociedade } \\ & \text { Internacional de Cefaleias) } \\ \text { IMAO } & \text { inibidores da monoaminoxidase } \\ \text { MIDAS } & \text { Migraine Disability Assessment Questionnaire } \\ \text { NaSRI } & \text { inibidores da recaptação da serotonina e } \\ & \text { noradrenalina } \\ \text { NMDA } & \text { N-metil -D-aspartato } \\ \text { OMS } & \text { Organização Mundial de Saúde } \\ \text { OR } & \text { odds ratio }\end{array}$

PREEMPT Phase 3 REsearch Evaluating Migraine Prophylaxis Therapy

PRO patient reported outcomes

RR risco relativo

SP Substância P

SPC Sociedade Portuguesa de Cefaleias

SNC Sistema nervoso central

SNP Sistema nervoso periférico

SSRI inibidores seletivos da recaptação de serotonina

SNRI inibidores da recaptação da serotonina/ noradrenalina

SU Serviço de Urgência

SUNA Short-lasting unilateral neuralgiform headache attacks with autonomic symptom

SUNCT Short-lasting unilateral neuralgiform headache attacks with conjunctival injection and tearing

TA tensão arterial

TCC terapia cognitivo-comportamental

TEP tromboembolismo pulmonar

TSH terapêutica hormonal de substituição

TVP trombose venosa profunda

YLD years living with disability (anos vividos com a incapacidade).

\section{Responsabilidades Éticas}

Conflitos de Interesse: Os autores declaram não possuir conflitos de interesse.

Suporte Financeiro: O presente trabalho não foi suportado por nenhum subsidio o bolsa ou bolsa.

Proveniência e Revisão por Pares: Não comissionado; revisão externa por pares.

Ethical Disclosures

Conflicts of interest: The authors have no conflicts of interest to declare.

Financial Support: This work has not received any contribution grant or scholarship.

Provenance and Peer Review: Not commissioned; externally peer reviewed.

\section{References / Referências}

Capitulo 1 - Princípios Gerais no Tratamento das Cefaleias

1. Vos T, Abajobir AA, Abbafati C, Abbas KM, Abate KH, AbdAllah $F$, et al. Global, regional, and national incidence, prevalence, and years lived with disability for 328 diseases and injuries for 195 countries, 1990-2016: a systematic analysis for the Global Burden of Disease Study 2016. Lancet. 2017; 390: 1211-59. doi: 10.1016/S0140-6736(17)32154-2.

2. Katsarava Z, Mania M, Lampl C, Herberhold J, Steiner TJ. Poor medical care for people with migraine in Europe evidence from the Eurolight study. J Headache Pain. 2018; 19:10. doi: 10.1186/s10194-018-0839-1 
3. Pereira Monteiro J, Esperança P, Machado G, Ribeiro C Luzeiro I. Recomendações Terapêuticas para Cefaleias. $2^{a}$ Edição. Sinapse 2009 ; Supl 1:9:1-36.

4. Pereira Monteiro J, Barros J, Esperança P, Fernandes G, GilGouveia R, Luzeiro I, et al. Classificação Internacional de Cefaleias - 3a Edição, Tradução Portuguesa. Sinapse. 2018; 18:1-172

5. Direção Geral da Saúde. Normas Clínicas Graus de Recomendação e Níveis de Evidência. [consultado Abril 2020] Disponível em http://www.dgs.pt/ficheiros-de-upload-3/ normas-clinicas-graus-de-recomendacao-e-niveis-de-evidencia-pdf.aspx

\section{Capitulo 2 - Princípios Gerais no Tratamento das Cefaleias}

1. Awais O, Marmura M, Silberstein S. Headache Guidelines. Medlink, February 2019

2. Donnet $A$ et al. French guidelines for diagnosis and treatment of classical trigeminal neuralgia. Rev Neurol. 2017; 173: 131-151. doi: 10.1016/j.neurol.2016.12.033.

3. Becker WJ, Findlay T, Moga C, Scott NA, Harstall C, Taenzer P. Guideline for primary care management of headache in adults. Can Fam Physician. 2015;61:670-9.

4. Reuter U, McClure C, Liebler E, Pozo-Rosich P. Non-invasive neuromodulation for migraine and cluster headache: a systematic review of clinical trials. J Neurol Neurosurg Psychiatry. 2019;90:796-804. doi: 10.1136/jnnp-2018-320113.

5. Rajapakse T, Pringsheim T. Nutraceuticals in migraine. Headache. 2016; 56: 808-16. doi: 10.1111/head.12789.

6. Orr S. Diet and nutraceutical interventions for headache management: A review of the evidence. Cephalalgia. 2016; 12:1112-33. doi: 10.1177/0333102415590239. 1

7. Pereira Monteiro J, Esperança P, Machado G, Ribeiro C, Luzeiro I. Recomendações Terapêuticas para Cefaleias. $2^{a}$ Edição. Sinapse 2009; Supl 1:9 (2):1-36.

8. Princípios europeus da abordagem das cefaleias comuns nos cuidados de saúde primários. Tradução do original, da Campanha Global "Lifting the Burden" em Março de 2010 pela Sociedade Portuguesa de Cefaleias. Lisboa: SPC; 2010.

9. Pereira Monteiro J, Barros J, Esperança P, Fernandes G, Gil-Gouveia R, Luzeiro I, et al. Classificação Internacional de Cefaleias - 3a Edição, Tradução Portuguesa. Sinapse. 2018:18:1-172.

10. Steiner TJ, MacGregor EA, Davies PT. BASH Management Guidelines - British Association for the Study of Headache. London: BASH; 2019.

11. Manias P, Tagaris G, Karageorgiou K. Acupuncture in Headache: A Critical Review. The Clin J Pain. 2000;16: 334-9. doi: 10.1097/00002508-200012000-00010

12. Linde $K$, Allais, G, White $A$, Fei $Y$, Mehring $M$, Shin $B C$, et al. Cochrane database of systematic reviews. 2016;4: Acupuncture for the prevention of tension-type headache. Cochrane Database Syst Rev. 2016;4:CD007587. doi: 10.1002/14651858.CD007587.pub2

13. Matsuzawa $Y$, Lee YS, et al. Barriers to behavioral treatment adherence for headache: An examination of attitudes, beliefs and psychiatric factors. Headache. 2019;59:19-31. doi: 10.1111/head.13429.

14. Harris P, Loveman E, Clegg A, Easton S, Berry N. Systematic review of cognitive behavioural therapy for the management of headaches and migraines in adults. $\mathrm{Br} \mathrm{J}$ Pain. 2015;9:213-24. doi: 10.1177/2049463715578291

15. Hugue A, McGrath PJ, Stinson J More. Efficacy of Psychological Treatment for Headaches: An Overview of Systematic Reviews and Analysis of Potential Modifiers of Treatment Efficacy. Clin J Pain. 2014; 30:353-69. doi: 10.1097/ ajp.0b013e318298dd8b

16. Hammond DC. Review of the efficacy of clinical hypnosis with headaches and migraines. Int J Clin Exp Hypn. 2007;55: 207-19. doi: 10.1080/00207140601177921.

17. Lake AE III. Behavioral and nonpharmacological treatments of headache. Med Clin North Am. 2001:85:1055-75. do: 10.1016/s0025-7125(05)70359-x.

18. Zhu S, Marmura M. Non-invasive neuromodulation for headache disorders. Curr Neurol Neurosci Rep. 2016;16:11. doi: 10.1007/s11910-015-0620-7.

\section{Capítulo 3 - Enxaqueca}

\section{Capítulo 3.1 - Medidas Gerais}

1. Pereira Monteiro J, Barros J, Esperança P, Fernandes G, GilGouveia R, Luzeiro I, et al. Classificação Internacional de Cefaleias - 3a Edição, Tradução Portuguesa. Sinapse. 2018; 18:1-172.

2. Rosenberg L, Butler N, Seng EK. Health behaviours in episodic migraine: why behaviour change matters. Curr Pain Headache Rep. 2018;22:6. doi: 10.1007/s11916-018-07215.

3. Steiner TJ, Jensen R, Katsarava Z, Linde M, MacGregor EA, Osipova $\mathrm{V}$, et al. Aids to management of headache disorders in primary care (2nd edition) on behalf of the European Headache Federation and Lifting The Burden: the Global Campaign against Headache. J Headache Pain. 2019;20:57. doi: 10.1186/s10194-018-0899-2.

4. Woldeamanuel YW, Cowan RP. The impact of regular lifestyle behaviour in migraine: a prevalence case-referent study. J Neurol. 2016;263:669-76. doi: 10.1007/s00415016-8031-5.

5. Park JW, Chu MK, Kim JM, Park SG, Cho SJ. Analysis of trigger factors in episodic migraineurs using a smartphone headache diary application. PloS One. 2016;11: e0149577. doi: 10.1371/journal.pone.0149577.

6. Pellegrino AB, Davis-Martin RE, Houle TT, Turner DP, Smitherman T. A. Perceived triggers of primary headache disorders: A meta-analysis. Cephalalgia. 2017; 38:1188-98. doi:10.1177/0333102417727535

Capítulo 3.2 - Tratamento Sintomático da Crise de Enxaqueca

1. Headache Classification Committee of the International Headache Society (IHS) The International Classification of Headache Disorders, 3rd edition. Cephalalgia. 2018;38:1211. doi: $10.1177 / 0333102417738202$.

2. Melchart D, Linde $K$, Fischer $P$, et al. Acupuncture for recurrent headaches: a systematic review of randomized controlled trials. [Erratum appears in Cephalalgia. 2000;20:7623]. Cephalalgia. 1999;19:779-86; discussion 765. doi: 10.1046/j.1468-2982.1999.1909779.x

3. Melchart D, Thormaehlen J, Hager S, Liao J, Linde K, Weidenhammer W. Acupuncture versus placebo versus sumatriptan for early treatment of migraine attacks: A randomized controlled trial. J Intern Med. 2003;253:181-8. doi:10.1046/j.1365-2796.2003.01081.x

4. Chou DE, Gross GJ, Casadei CH, Yugrakh MS. External Trigeminal Nerve Stimulation for the Acute Treatment of Migraine: Open-Label Trial on Safety and Efficacy. Neuromodulation Technol Neural Interface. 2017;20:678-83. doi:10.1111/ner.12623

5. Rapoport AM, Edvinsson L. Some aspects on the pathophysiology of migraine and a review of device therapies for migraine and cluster headache. Neurol Sci. 2019;40:75-80. doi:10.1007/s10072-019-03828-0

6. Xu H, Han W, Wang J, Li M. Network meta-analysis of migraine disorder treatment by NSAIDs and triptans. J Headache Pain. 2016;17:113. doi:10.1186/s10194-016-0703-0

7. Thorlund K, Mills EJ, Wu P, et al. Comparative efficacy of triptans for the abortive treatment of migraine: A multiple treatment comparison meta-analysis. Cephalalgia. 2014:34:258-67. doi:10.1177/0333102413508661

8. Diener H-C, Holle-Lee D, Nägel S, Dresler T, Gaul C, Göbel $\mathrm{H}$, et al. Treatment of migraine attacks and prevention of migraine: Guidelines by the German Migraine and Headache Society and the German Society of Neurology. Clin Transl Neurosci. 2019;3:1-40. doi:10.1177/2514183×18823377

9. Taggart E, Doran S, Kokotillo A, Campbell S, Villa-Roel C, Rowe $\mathrm{BH}$. Ketorolac in the treatment of acute migraine: 
a systematic review. Headache. 2013;53:277-87. doi: 10.1111/head.12009.

10. Woldeamanuel YW, Rapoport AM, Cowan RP. What is the evidence for the use of corticosteroids in migraine? Curr Pain Headache Rep. 2014 Dec;18(12):464. doi: 10.1007/ s11916-014-0464-x. PMID: 25373608.

11. Derry CJ, Derry S, Moore RA. Sumatriptan (intranasal route of administration) for acute migraine attacks in adults. Cochrane Database Syst Rev. 2012;2012:10. doi:10.1002/14651858.CD009663

12. Derry CJ, Derry S, Moore RA. Sumatriptan (subcutaneous route of administration) for acute migraine attacks in adults. Cochrane Database Syst Rev. 2014;2014: doi:10.1002/14651858.CD009665

13. Cameron C, Kelly S, Hsieh SC, et al. Triptans in the acute treatment of migraine: a systematic review and network meta-analysis. Headache. 2015;55:221-35. doi:10.1111/ head. 12601

14. Derry CJ, Derry S, Moore RA. Sumatriptan (oral route of administration) for acute migraine attacks in adults. Cochrane Database Syst Rev. 2012;2012. doi: 10.1002/14651858. CD008615.pub2

15. Pelzer N, Stam AH, Haan J, Ferrari MD, Terwindt GM. Familial and sporadic hemiplegic migraine: Diagnosis and treatment. Curr Treat Options Neurol. 2013;15:13-27. doi:10.1007/s11940-012-0208-3

16. Ferrari M. How to assess and compare drugs in the management of migraine: Success rates in terms of response and recurrence. Cephalalgia. 1999;19:2-8. doi:10.1177/0333102499019s2302

17. Evans RW, Tepper SJ, Shapiro RE, Sun-Edelstein C, Tietjen GE. The FDA alert on serotonin syndrome with use of triptans combined with selective serotonin reuptake inhibitors or selective serotonin-norepinephrine reuptake inhibitors: American headache society position paper. Headache. 2010;50:1089-99. doi:10.1111/j.1526-4610.2010. 01691.x

18. Marmura MJ, Silberstein SD, Schwedt TJ. The Acute Treatment of Migraine in Adults: The American Headache Society Evidence Assessment of Migraine Pharmacotherapies. Headache J Head Face Pain. 2015;55:3-20. doi:10.1111/ head.12499.

19. Acute treatment of migraine attacks: efficacy and safety of a nonsteroidal anti-inflammatory drug, diclofenacpotassium, in comparison to oral sumatriptan and placebo. The Diclofenac-K/Sumatriptan Migraine Study Group. Cephalalgia. 1999;19:232-40. doi: 10.1046/j.14682982.1999.019004232.x.

20. Diener HC, Bussone G, De Liano H, Eikermann A, Englert R, Floeter $\mathrm{T}$, et al. Placebo-controlled comparison of effervescent acetylsalicylic acid, sumatriptan and ibuprofen in the treatment of migraine attacks. Cephalalgia. 2004;24:94754. doi:10.1111/j.1468-2982.2004. 00783.x

21. Goldstein J, Silberstein SD, Saper JR, Elkind $A H$, Smith TR, Gallagher RM, et al. Acetaminophen, aspirin, and caffeine versus sumatriptan succinate in the early treatment of migraine: Results from the ASSET trial. Headache. 2005:45:973-82. doi:10.1080/13543784.2019.1618830

22. Walker S. New Medications in the Treatment of Acute Migraine. Hosp Pharm. 2019;54:229-31. doi:10.1111/j.1526-4610.2005. 05177.x

23. Negro A, Martelletti P. Gepants for the treatment of migraine. Expert Opin Investig Drugs. 2019;28:555-67. doi:10.1177/0018578719844701

Capitulo 3.3 - Tratamento Preventivo da Enxaqueca Episódica

1. Headache Classification Committee of the International Headache Society (IHS) The International Classification of Headache Disorders, 3rd edition. Cephalalgia. 2018;38:1211. doi: $10.1177 / 0333102417738202$.

2. American Headache Society. The American Headache Society position statement on integrating new migraine treatments into clinical practice. Headache. 2019;59: 1-8.doi: 10.1111/head.13456.

3. Lipton RB, Bigal ME, Diamond M, Freitag F, Reed ML, Stewart WF. Migraine prevalence, disease burden, and the need for preventive therapy. Neurology. 2007; 68:343-349. doi: 10.1212/01.wnl.0000252808.97649.21.

4. Stewart WF, Lipton RB, Dowson AJ, Sawyer J. Development and testing of the Migraine Disability Assessment (MIDAS) Questionnaire to assess headache-related disability. Neurology. 2001;56: S20-S28). doi: 10.1212/wnl.56.suppl_1. s20.

5. Holroyd KA, Cottrell CK, O'Donnell FJ, Cordingley GE, Drew JB, Carlson BW, et al. Effect of preventive (beta blocker) treatment, behavioural migraine management, or their combination on outcomes of optimised acute treatment in frequent migraine: Randomised controlled trial. BMJ. 2010;341:c4871. doi:10.1136/bmj.c4871.

6. Andrasik F. What does the evidence show? Efficacy of behavioural treatments for recurrent headaches in adults. Neurol Sci. 2007;28: S70-7. doi:10.1007/s10072-007-0754-8.

7. Sharpe L, Dudeney J, Williams ACC, Nicholas M, McPhee I, Baillie A, et al. Psychological therapies for the prevention of migraine in adults. Cochrane Database Syst Rev. 2019;7:CD012295. doi: 10.1002/14651858.CD012295. pub2.

8. Direção Geral da Saúde. Normas Clínicas Graus de Recomendação e Níveis de Evidência. [consultado Abril 2020] Disponível em: http:// www.dgs.pt/ficheiros-de-upload-3/ normas-clinicas-graus-de-recomendacao-e-niveis-de-evidencia-pdf.aspx

9. Linde K, Allais G, Brinkhaus B, Fei Y, Mehring M, Vertosick EA et al. Acupuncture for the prevention of episodic migraine. Cochrane Database Syst Rev. 2016;6:CD001218. doi: 10.1002/14651858.CD001218.pub3.

10. Steiner TJ, Jensen R, Katsarava Z, Linde M, MacGregor EA, Osipova $V$ et al. Aids to management of headache disorders in primary care (2nd edition): on behalf of the European Headache Federation and Lifting The Burden: the Global Campaign against Headache. J Headache Pain. 2019 ;20:57. doi: 10.1186/s10194-018-0899-2.

11. Reuter U, McClure C, Liebler E, Pozo-Rosich P. Non-invasive neuromodulation for migraine and cluster headache: a systematic review of clinical trials. J Neurol Neurosurg Psychiatry. 2019 ;90:796-804. doi: 10.1136/jnnp-2018-320113.

12. Schoenen J, Vandersmissen $B$, Jeangette $S$, Herroelen $L$, Vandenheede M, Gérard P, Magis D. Migraine prevention with a supraorbital transcutaneous stimulator: a randomized controlled trial. Neurology. 2013;80:697-704. doi: 10.1212/WNL.0b013e3182825055.

13. Schoenen JE. Migraine prevention with a supraorbital transcutaneous stimulator: A randomized controlled trial. Neurology. 2016;86:201-2. doi: 10.1212/01. wnl.0000479686.32453.cc.

14. Hord ED, Evans MS, Mueed S, Adamolekun B, Naritoku DK. The effect of vagus nerve stimulation on migraines. J Pain. 2003;4:530-4. doi: 10.1016/j.jpain.2003.08.001.

15. Diener HC, Goadsby PJ, Ashina M, Al-Karagholi MA, Sinclair $A$, et al. Non-invasive vagus nerve stimulation ( $n V N S$ ) for the preventive treatment of episodic migraine: The multicentre, double-blind, randomised, sham-controlled PREMIUM trial. Cephalalgia. 2019;39:1475-87. doi: 10.1177/0333102419876920.

16. Silberstein SD. Preventive migraine treatment. Continuum. 2015; 21:973-89. doi: 10.1212/CON.0000000000000199.

17. Lantéri-Minet M, Valade D, Géraud G, Lucas C, Donnet A. Prise en charge diagnostique et thérapeutique de la migraine chez l'adulte et chez l'enfant. Rev Neurol.2013; 169:144-29. doi: 10.1016/j.neurol.2012.07.022.

18. Diener HC, Agosti R, Allais G, Bergmans P, Bussone G, Davies $B$, et al. Cessation versus continuation of 6-month migraine preventive therapy with topiramate (PROMPT): a randomised, double-blind, placebo-controlled trial. Lancet. 2007; 6:1054-62. doi: 10.1016/S1474-4422(07)70272-7 
19. Danesh A, Christopher P, Gottschalk H. Beta-blockers for Migraine Prevention: a Review article. Curr Treat Options Neurol.2019;21:20. doi: 10.1007/s11940-019-0556.

20. Sprenger T, Viana M,Tassorelli C. Current prophylactic medications for migraine and their potential mechanisms of action. Neurotherapeutics. 2018; 15:313-2. doi: 10.1007/ s13311-018-0621-8.

21. Shields KG, Goadsby PJ. Propranolol modulates trigeminovascular responses in thalamic ven-troposteromedial nucleus: a role in migraine? Brain. 2005; 128:86-97. doi: 10.1093/ brain/awh298.

22. Schoenen J, Ambrosini A, Sándor PS, Maertens de Noordhout A. Evoked potentials and transcranial magnetic stimulation in migraine: published data and viewpoint on their pathophysiologic significance. Clin Neurophysiol. 2003; 114:955-72. doi: 10.1016/s1388-2457(03)00024-5.

23. Nyrke $T$, Kangasniemi $P$, Lang $A H$, Petersen E. Steady-state visual evoked potentials during migraine prophylaxis by propranolol and femoxetine. Acta Neurol Scand. 1984;69:914. doi:10.1111/j.1600-0404. 1984.tb07773.x.

24. Gerwig M, Niehaus L, Stude $P$, Katsarava Z, Diener HC. Beta-blocker migraine prophylaxis affects the excitability of the visual cortex as revealed by transcranial magnetic stimulation. J Headache Pain. 2012; 13:83-9. doi:10.1007/ s10194-011-0401-x.

25. Loder E, Burch R, Rizzoli P. The 2012 AHS/AAN guidelines for prevention of episodic migraine: a summary and comparison with other recent clinical practice guidelines. Headache. 2012; 52:930-45. doi:10.1111/j.15264610.2012.02185.x.

26. Tfelt-Hansen P, Pascual J, Ramadan N, Dahlöf C, D'Amico D, Diener HC, et al. International Headache Society Clinical Trials Subcommittee. Guidelines for controlled trials of drugs in migraine: third edition. A guide for investigators. Cephalalgia. 2012; 32:6-38. doi: 10.1177/0333102411417901. PMID: 22384463.

27. Jackson JL, Kuriyama A, Kuwatsuka Y, Nickoloff S, Storch $D$, Jackson W, et al . Beta-blockers for the prevention of headache in adults, a systematic review and meta-analysis. PLoS One. 2019;14:e0212785. doi: 10.1371/journal. pone.0212785.

28. Jensen R, Brinck T, Olesen J. Sodium valproate has a prophylactic effect in migraine without aura: a triple-blind, placebo-controlled crossover study. Neurology. 1994; 44:64751. doi: 10.1212/wnl.44.4.647

29. Ashtari F, Shaygannejad V, Akbari M. A double-blind, randomized trial of low-dose topiramate vs propranolol in migraine prophylaxis. Acta Neurol Scand. 2008; 118:301-5. doi: 10.1111/j.1600-0404.2008.01087.x.

30. Diener HC, Tfelt-Hansen P, Dahlöf C, Láinez MJ, Sandrini G, Wang SJ, et al. MIGR-003 Study Group. Topiramate in migraine prophylaxis--results from a placebo-controlled trial with propranolol as an active control. J Neurol. 2004; 251:943-50. doi: 10.1007/s00415-004-0464-6.

31. Olsson JE, Behring HC, Forssman B, Hedman C, Hedman $G$, Johansson F, et al. Metoprolol and propranolol in migraine prophylaxis: a double-blind multicentre study. Acta Neurol Scand. 1984;70:160-8. doi: 10.1111/j.1600-0404. 1984.tb00815.x.

32. Tfelt-Hansen P, Agesen FN, Furberg N, Tfelt-Hansen J. Pharmacokinetic variability of drugs used for the prophylactic treatment of migraine. CNS Drugs. 2017; 31:389-40. doi:10.1007/s40263-017-0430-3.

33. al-Qassab HK, Findley LJ. Comparison of propranolol LA $80 \mathrm{mg}$ and propranolol LA $160 \mathrm{mg}$ in migraine prophylaxis: a placebo-controlled study. Cephalalgia. 1993; 13:128-31. doi: 10.1046/j.1468-2982.1993.1302128.x.

34. Steiner TJ, Joseph R, Hedman C, Rose FC. Metoprolol in the prophylaxis of migraine: parallel-groups comparison with placebo and dose-ranging follow-up. Headache. 1988;28:15-23. doi: 10.1111/j.1365-2524.1988. hed2801015.x.
35. Pascual J, Leira R, Láinez JM. Combined therapy for migraine prevention? Clinical experience with a betablocker plus sodium valproate in 52 resistant migraine patients. Cephalalgia. 2003;23:961-2. doi: 10.1046/j.14682982.2003.00615.x

36. Pascual J, Rivas MT, Leira R. Testing the combination beta-blocker plus topiramate in refractory migraine. Acta Neurol Scand. 2007;115:81-3. doi: 10.1111/j.16000404.2006.00772.x.

37. Silberstein SD, Dodick DW, Lindblad AS, Holroyd K, Harrington M, Mathew NT, et al. Chronic Migraine Treatment Trial Research Group. Randomized, placebocontrolled trial of propranolol added to topiramate in chronic migraine. Neurology. 2012;78:976-84. doi: 10.1212/ WNL.0b013e31824d5846.

38. Dunlop D, Shanks RG. Selective blockade of adrenoceptive beta receptors in the heart. Br J Pharmacol Chemother. 1968:32:201-18. doi: 10.1111/j.1476-5381.1968.tb00444.x.

39. Dickstein K, Cohen-Solal A, Filippatos G, McMurray JJ, Ponikowski P, Poole-Wilson PA, et al; ESC Committee for Practice Guidelines (CPG). ESC Guidelines for the diagnosis and treatment of acute and chronic heart failure 2008: the Task Force for the Diagnosis and Treatment of Acute and Chronic Heart Failure 2008 of the European Society of Cardiology. Developed in collaboration with the Heart Failure Association of the ESC (HFA) and endorsed by the European Society of Intensive Care Medicine (ESICM). Eur Heart J. 2008;29:2388-442. doi: 10.1093/eurheartj/ehn309.

40. Frohlich ED, Tarazi RC, Dustan HP. Peripheral arterial insufficiency. A complication of beta-adrenergic blocking therapy. JAMA. 1969;208:2471-2. doi: 10.1001/jama.208.13.2471.

41. Ko DT, Hebert PR, Coffee CS, Sedrakyan A, Curtis JP, Krumholz HM. Beta-blocker therapy and symptoms of depression, fatigue, and sexual dysfunction. JAMA. 2002; 288:351-7. doi: 10.1001/jama.288.3.351.

42. Hepp Z, Bloudek LM, Varon SF. Systematic review of migraine prophylaxis adherence and persistence. J Manag Care Pharm. $2014 ; 20: 22-33$. doi: 10.18553/jmcp.2014.20.1.22.

43. Hepp Z, Dodick DW, Varon SF, Chia J, Matthew N, Gillard $P$, et al. Persistence and switching patterns of oral migraine prophylactic medications among patients with chronic migraine: A retrospective claims analysis. Cephalalgia. 2017;37:470-485. doi: 10.1177/0333102416678382.

44. Blumenfeld AM, Bloudek LM, Becker WJ, Buse DC, Varon $\mathrm{SF}$, Maglinte GA, et al. Patterns of use and reasons for discontinuation of prophylactic medications for episodic migraine and chronic migraine: results from the second international burden of migraine study (IBMS-II). Headache. 2013;53:644-55. doi: 10.1111/head.12055

45. Stubberud A, Flaaen NM, McCrory DC, Pedersen SA, Linde M. Flunarizine as prophylaxis for episodic migraine: a systematic review with meta-analysis. Pain. $2019 ; 160: 762-72$. doi: 10.1097/j.pain.0000000000001456.

46. Diener HC, Matias-Guiu J, Hartung E, Pfaffenrath V, Ludin HP, Nappi G, et al. Efficacy and tolerability in migraine prophylaxis of flunarizine in reduced doses: a comparison with propranolol $160 \mathrm{mg}$ daily. Cephalalgia. 2002; 22:20921. doi: 10.1046/j.1468-2982.2002.t01-1-00309.x. Erratum in: Cephalalgia. 2002;22:488.

47. Luo N, Di W, Zhang A, Wang Y, Ding M, Qi W, et al . A randomized, one-year clinical trial comparing the efficacy of topiramate, flunarizine, and a combination of flunarizine and topiramate in migraine prophylaxis. Pain Med. 2012; 13:80-6. doi: 10.1111/j.1526-4637.2011.01295.x.

48. Fontes Ribeiro C. Enxaqueca - Terapêutica. In: Pavão Martins I, coordenadora. Cefaleias.Lisboa: Lidel Edições Técnicas; 2015.

49. RCM aprovado pelo INFARMED [consultado em 31-1-2020] Disponível em: http://app7.infarmed.pt/infomed/download_ficheiro.php?med_id=7871\&tipo_doc $=$ fi.

50. Linde M, Mulleners WM, Chronicle EP, McCrory DC. Valproate (valproic acid or sodium valproate or a combina- 
tion of the two) for the prophylaxis of episodic migraine in adults. Cochrane Database Syst Rev. 2013; 24;:CD010611. doi: 10.1002/14651858.CD010611.

51. Cutrer FM, Limmroth V, Moskowitz MA. Possible mechanisms of valproate in migraine prophylaxis. Cephalalgia. 1997;17:93-100. doi: 10.1046/j.1468-2982.1997.1702093.x.

52. Afshari D, Rafizadeh S, Rezaei M. A comparative study of the effects of low-dose topiramate versus sodium valproate in migraine prophylaxis. Int J Neurosci. 2012;122:60-8. doi: 10.3109/00207454.2011.626908.

53. Shaygannejad V, Janghorbani M, Ghorbani A, Ashtary F, Zakizade N, Nasr V. Comparison of the effect of topiramate and sodium valproate in migraine prevention: a randomized blinded crossover study. Headache. 2006;46:642-8. doi: 10.1111/j.1526-4610.2006.00413.x.

54. Pellock JM, Willmore LJ. A rational guide to routine blood monitoring in patients receiving antiepileptic drugs. Neurology. 1991;41:961-4. doi: 10.1212/wnl.41.7.961.

55. Edvinsson L, Linde M. New drugs in migraine treatment and prophylaxis: telcagepant and topiramate. Lancet. 2010; 21; 376:645-55. doi: 10.1016/S0140-6736(10)60323-6.

56. Brandes JL, Saper JR, Diamond M, Couch JR, Lewis DW, Schmitt J, et al. MIGR-002 Study Group. Topiramate for migraine prevention: a randomized controlled trial. JAMA. 2004;291):965-73. doi: 10.1001/jama.291.8.965.

57. Silberstein SD, Neto W, Schmitt J, Jacobs D; MIGR-001 Study Group. Topiramate in migraine prevention: results of a large controlled trial. Arch Neurol. 2004; 61:490-5. doi: 10.1001/archneur.61.4.490.

58. Linde M, Mulleners WM, Chronicle EP, McCrory DC. Topiramate for the prophylaxis of episodic migraine in adults. Cochrane Database Syst Rev. 2013; 24: CD010610. doi: 10.1002/14651858.CD010610.

59. Dodick DW, Freitag F, Banks J, Saper J, Xiang J, Rupnow M, Biondi D, Greenberg SJ, Hulihan J; CAPSS-277 Investigator Group. Topiramate versus amitriptyline in migraine prevention: a 26-week, multicenter, randomized, double-blind, double-dummy, parallel-group noninferiority trial in adult migraineurs. Clin Ther. 2009; 31:542-59. doi: 10.1016/j. clinthera.2009.03.020.

60. Parikh SK, Silberstein SD. Preventive Treatment for Episodic Migraine. Neurol Clin. 2019; 37:753-70. doi: 10.1016/j. ncl.2019.07.004.

61. Linde M, Mulleners WM, Chronicle EP, McCrory DC. Gabapentin or pregabalin for the prophylaxis of episodic migraine in adults. Cochrane Database Syst Rev. 2013 24;2013:CD010609. doi: 10.1002/14651858.CD010609.

62. Linde M, Mulleners WM, Chronicle EP, McCrory DC. Antiepileptics other than gabapentin, pregabalin, topiramate, and valproate for the prophylaxis of episodic migraine in adults. Cochrane Database Syst Rev. 2013 24:CD010608. doi: 10.1002/14651858.CD010608.

63. Galletti F, Cupini LM, Corbelli I, Calabresi P, Sarchielli P. Pathophysiological basis of migraine prophylaxis. Prog Neurobiol. 2009; 89:176-92. doi: 10.1016/j.pneurobio.2009.07.005

64. Jackson JL, Cogbill E, Santana-Davila R, Eldredge C, Collier W, Gradall A et al. A Comparative Effectiveness Meta-Analysis of Drugs for the Prophylaxis of Migraine Headache. PLoS One. 2015; 14;10:e0130733. doi: 10.1371/journal. pone. 0130733 .

65. Ozyalcin SN, Talu GK, Kiziltan E, Yucel B, Ertas M, Disci R. The efficacy and safety of venlafaxine in the prophylaxis of migraine. Headache. 2005;45:144-52. doi: 10.1111/j.15264610.2005.05029.x.

66. Bulut S, Berilgen MS, Baran A, Tekatas A, Atmaca M, Mungen $B$. Venlafaxine versus amitriptyline in the prophylactic treatment of migraine: randomized, double-blind, crossover study. Clin Neurol Neurosurg. 2004; 107:44-8. doi: 10.1016/j.clineuro.2004.03.004.

67. Mottur-Pilson C, Snow V, Wall E, Weiss K. Pharmacologic Management of Acute Attacks of Migraine and Prevention of Migraine Headache. Ann Int Med. 2002;137: 840-9. doi. org/10.7326/0003-4819-137-10-200211190-00014.

68. Infarmed: Prontuário Terapêutico online. [cosultado em 15/12/2020]. Disponível em htpps://www. http://app10.infarmed.pt/prontuario/index.php.

69. Rau JC, Dodick DW. Other Preventive Anti-Migraine Treatments: ACE Inhibitors, ARBs, Calcium Channel Blockers, Serotonin Antagonists, and NMDA Receptor Antagonists. Curr Treat Options Neurol. 2019;21:17. doi: 10.1007/ s11940-019-0559-0.

70. Tronvik E, Stovner LJ, Helde G, Sand T, Bovim G. Prophylactic treatment of migraine with an angiotensin II receptor blocker: a randomized controlled trial. JAMA. 2003; 289:65-9. doi: 10.1001/jama.289.1.65.

71. Stovner LJ, Linde M, Gravdahl GB, Tronvik E, Aamodt AH, Sand $T$ et al. A comparative study of candesartan versus propranolol for migraine prophylaxis: A randomised, tripleblind, placebo-controlled, double cross-over study. Cephalalgia. 2014; 34:523-32. doi: 10.1177/0333102413515348.

72. Long $R$, Zhu Y, Zhou S. Therapeutic role of melatonin in migraine prophylaxis: A systematic review. Medicine. 2019;98: e14099. doi: 10.1097/MD.0000000000014099.

73. Guilbot A, Bangratz M, Ait Abdellah S, Lucas C. A combination of coenzyme Q10, feverfew and magnesium for migraine prophylaxis: a prospective observational study. BMC Complement Altern Med. 2017;17:433. doi: 10.1186/ s12906-017-1933-7.

74. Zhang $H$, Yang $X$, Lin $Y$, Chen L, Ye $H$. The efficacy of greater occipital nerve block for the treatment of migraine: A systematic review and meta-analysis. Clin Neurol Neurosurg. 2018; 165:129-33. doi: 10.1016/j.clineuro.2017.12.026

75. Inan LE, Inan N, Unal-Artık HÁ, Atac C Babaogle C. Greater occipital nerve block in migraine prophylaxis: Narrative review. Cephalalgia. 2019;39:908-920. doi: 10.1177/0333102418821669.

76. Edvinsson L, Haanes KA, Warfvinge K, Krause DN. CGRP as the target of new migraine therapies - successful translation from bench to clinic. Nat Rev Neurol. 2018; 14:338-50. doi:10.1038/s41582-018-0003-1.

77. Amara SG, Jonas V, Rosenfeld MG, Ong ES, Evans RM. Alternative RNA processing in calcitonin gene expression generates mRNAs encoding different polypeptide products. Nature. 1982;298: 240-4. doi: 10.1038/298240a0.

78. Goadsby PJ, Edvinsson L. Human in vivo evidence for trigeminovascular activation in cluster headache. Neuropeptide changes and effects of acute attacks therapies. Brain. 1994; 117:427-34. doi:10.1093/brain/117.3.427.

79. Ashina M, Hansen JM, Á Dunga BO, Olesen J. Human models of migraine - short-term pain for long-term gain. Nat Rev Neurol. 2017; 13:713-24. doi:10.1038/nrneurol.2017.137.

80. Rapoport AM, McAllister P. The Headache Pipeline: Excitement and Uncertainty. Headache. 2020 ;60:190-9. doi: 10.1111/head.13728.

81. Chan C, Goadsby PJ. Recent Advances in Pharmacotherapy for Episodic Migraine. CNS Drugs. 2019;33:1053-71. doi:10.1007/s40263-019-00665-9.

82. Berger A, Bloudek LM, Varon SF, Oster G. Adherence with migraine prophylaxis in clinical practice. Pain Pract. 2012; 12:541-9. doi: 10.1111/j.1533-2500.2012.00530.x.

83. Reuter U, Goadsby PJ, Lanteri-Minet M, Wen S, HoursZesiger $\mathrm{P}$, Ferrari MD, Klatt J. Efficacy and tolerability of erenumab in patients with episodic migraine in whom twoto-four previous preventive treatments were unsuccessful: a randomised, double-blind, placebo-controlled, phase 3b study. Lancet. 2018; 392:2280-7. doi: 10.1016/S01406736(18)32534-0.

84. Alasad YW, Asha MZ. Monoclonal antibodies as a preventive therapy for migraine: A meta-analysis Clin $\mathrm{Neu}$ rol Neurosurg. 2020; 195:105900. doi:10.1016/j.clineuro.2020.10590.

85. Deng H, Li GG, Nie H, Feng YY, Guo GY, Guo WL, Tang ZP. Efficacy and safety of calcitonin-gene-related peptide 
binding monoclonal antibodies for the preventive treatment of episodic migraine - an updated systematic review and meta-analysis. BMC Neurol. 2020 ;20:57. doi: 10.1186/ s12883-020-01633-3.

86. Tfelt-Hansen P, Pascual J, Ramadan N, Dahlöf C, D'Amico D, Diener HC, et al. International Headache Society Clinical Trials Subcommittee. Guidelines for controlled trials of drugs in migraine: third edition. A guide for investigators. Cephalalgia. 2012;32:6-38. doi: 10.1177/0333102411417901.

87. Ashina M, Saper J, Cady R, Schaeffler BA, Biondi DM, Hirman, et al. Eptinezumab in episodic migraine: A randomized, double-blind, placebo-controlled study (PROMISE-1). Cephalalgia. $2020 ; 40$ :241-54. doi: 10.1177/0333102420905132.

88. Lipton RB, Goadsby PJ, Smith J, Schaeffler BA, Biondi DM, Hirman J, et al. Efficacy and safety of eptinezumab in patients with chronic migraine: PROMISE-2. Neurology. 2020;94:e1365-e1377. doi: 10.1212/ WNL.0000000000009169.

89. Goadsby PJ, Reuter U, Hallström Y, Broessner G, Bonner JH, Zhang F, et al. A Controlled Trial of Erenumab for Episodic Migraine. N Engl J Med. 2017;377:2123-32. doi: 10.1056/NEJMoa1705848.

90. Dodick DW, Ashina M, Brandes JL, Kudrow D, Lanteri-Minet $\mathrm{M}$, Osipova $\mathrm{V}$, et al. ARISE: A Phase 3 randomized trial of erenumab for episodic migraine. Cephalalgia. 2018;38:102637. doi: $10.1177 / 0333102418759786$.

91. Zhu C, Guan J, Xiao H, Luo W, Tong R. Erenumab safety and efficacy in migraine: A systematic review and meta-analysis of randomized clinical trials. Medicine. 2019;98:e18483. doi: 10.1097/MD.0000000000018483.

92. Dodick DW, Silberstein SD, Bigal ME, Yeung PP, Goadsby PJ, Blankenbiller T, et al. Effect of frema-nezumab compared with placebo for prevention ofepisodic migraine: a randomized clinical trial. JAMA. 2018:319:1999-2008. doi: 10.1001/jama.2018.4853.

93. Ferrari MD, Diener HC, Ning X, Galic M, Cohen J, Yang R, et al. Fremanezumab versus placebo for migraine prevention in patients with documented failure to up to four migraine preventive medica-tion classes (FOCUS): a randomised, double-blind, placebo-controlled, phase $3 \mathrm{~b}$ trial. Lancet. 2019; 394:1030-40. doi: 10.1016/s0140-6736(19)31946-4.

94. Gao B, Sun N, Yang Y, Sun Y, Chen M, Chen Z, Wang Z. Safety and Efficacy of Fremanezumab for the Prevention of Migraine: A Meta-Analysis From Randomized Controlled Trials. Front Neurol. 2020;11:435. doi: 10.3389/ fneur.2020.00435.

95. Stauffer VL, Dodick DW, Zhang Q, Carter JN, Ailani J, Conley RR. Evaluation of Galcanezumab for the Prevention of Episodic Migraine: The EVOLVE-1 Randomized Clinical Trial. JAMA Neurol. 2018;75:1080-8. doi: 10.1001/jamaneurol.2018.1212. Erratum in: JAMA Neurol. 2019;76:872.

96. Skljarevski V, Matharu M, Millen BA, Ossipov MH, Kim BK, Yang JY. Efficacy and safety of galcanezumab for the prevention of episodic migraine: Results of the EVOLVE-2 Phase 3 randomized controlled clinical trial. Cephalalgia. $2018 ; 38: 1442-54$. doi: 10.1177/0333102418779543.

97. Mulleners W, Kim BK, I Lainez M, Lanteri-Minet M, Aurora S, Nichols R, et al . A Randomized, Placebo-Controlled Study of Galcanezumab in Patients with Treatment-Resistant Migraine: Double-Blind Results from the CONQUER Study. Neurology. 2020; 94:162.

98. Zhao X, Xu X, Li Q. Efficacy and safety of galcanezumab for preventive treatment of migraine: a systematic review and meta-analysis. J Neurol. 2020(in press) doi: 10.1007/ s00415-020-09707-5.

99. Forbes RB, McCarron M, Cardwell CR. Efficacy and Contextual (Placebo) Effects of CGRP Antibodies for Migraine: Systematic Review and Meta-analysis. Headache. 2020 (in press). doi: 10.1111/head.13907.
100. Sacco S, Bendtsen L, Ashina M, Reuter U, Terwindt G, Mitsikostas DD, Martelletti P. European headache federation guideline on the use of monoclonal antibodies acting on the calcitonin gene related peptide or its receptor for migraine prevention. J Headache Pain. 2019;20:6. doi: 10.1186/s10194-018-0955-y. Erratum in: J Headache Pain. 2019;20:58

101. Ashina $M$, Goadsby PJ, Reuter $U$, Silberstein $S$, Dodick $D$, Rippon GA, et al. Long-term safety and tolerability of erenumab: Three-plus year results from a five-year openlabel extension study in episodic migraine. Cephalalgia. 2019 ;391):1455-1464. doi: 10.1177/0333102419854082.

102. Erenumab - RCM [consultado em 30/7/2020]Disponível em: https://ec.europa.eu/health/documents/communityregister/2019/20190823145611/anx_145611_pt.pdf

103. Fremanezumab - SmPC [consultado em 30/7/2020] Disponível em: https://www.ema.europa.eu/en/documents/ product-information/ajovy-epar-product-information en.pdf

104. Galcanezumab - SmPC: [consultado em 30/7/2020] Disponível em https:/www.ema.europa.eu/en/documents/ product-information/emgality-epar-product-information_ en.pdf

105. Eptinezumab - AHFS Monographs[consultado em 30/7/2020] Disponível em: https://www.drugs.com/monograph/vyepti.html

106. Ducourau E, Mulleman D, Paintaud G, Miow Lin DC, Lauferon $F$, Ternant $D$, et al. Antibodies toward infliximab are associated with low infliximab concentration at treatment initiation and poor infliximab maintenance in rheumatic diseases. Arthritis Res Ther. 2011;13:R105.

107. Chaigne $\mathrm{B}$, Watier $\mathrm{H}$. Monoclonal antibodies in excess: A simple way to avoid immunogenicity in patients? J Allergy Clin Immunol. 2015;136:814-6. doi: 10.1016/j. jaci.2015.03.013

108. Rup B, Pallardy $M$, Sikkema $D$, Albert $T$, Allez $M$, Broet $\mathrm{P}$, et al. ABIRISK Consortium. Standardizing terms, definitions and concepts for describing and interpreting unwanted immunogenicity of biopharmaceuticals: recommendations of the Innovative Medicines Initiative ABIRISK consortium. Clin Exp Immunol. 2015 ;181:385-400. doi: 10.1111/cei.12652.

109. Rutgeerts $P$, Feagan BG, Lichtenstein GR, Mayer LF, Schreiber S, Colombel JF, et al: Comparison of scheduled and episodic treatment strategies of infliximab in Crohn's disease. Gastroenterology. 2004; 126: 402-13. doi: 10.1053/j.gastro.2003.11.014.

110. Xu D, Chen D, Zhu LN, Tan G, Wang HJ, Zhang Y, Liu L. Safety and tolerability of calcitonin-gene-related peptide binding monoclonal antibodies for the prevention of episodic migraine - a meta-analysis of randomized controlled trials. Cephalalgia. 2019;39:1164-79. doi: 10.1177/0333102419829007.

111. Depre C, Antalik L, Starling A, Koren M, Eisele O, Lenz RA, Mikol DD. A Randomized, Double-Blind, PlaceboControlled Study to Evaluate the Effect of Erenumab on Exercise Time During a Treadmill Test in Patients with Stable Angina. Headache. 2018;58:715-23. doi: 10.1111/ head.13316.

112. Lattanzi S, Brigo F, Trinka E, Vernieri F, Corradetti T, Dobran M , Silvestrini M. Erenumab for Preventive Treatment of Migraine: A Systematic Review and Meta Analysis of Efficacy and Safety. Drug. 2019;79:417-31. doi: 10.1007/ s40265-019-01069-1. 


\section{Capitulo 3.4 - Tratamento da Enxaqueca Crónica}

1. Headache Classification Committee of the International Headache Society (IHS) The International Classification of Headache Disorders, 3rd edition. Cephalalgia. 2018;38:1211. doi: $10.1177 / 0333102417738202$.

2. Natoli JL, Manack A, Dean B, Butler Q, Turkel CC, Stovner L, Lipton RB. Global prevalence of chronic migraine: a systematic review. Cephalalgia. 2010;30:599-609. doi: 10.1111/j.1468-2982.2009.01941.x.

3. Buse DC, Manack AN, Fanning KM, Serrano D, Reed ML, Turkel CC, Lipton RB. Chronic migraine prevalence, disability, and sociodemographic factors: results from the American Migraine Prevalence and Prevention Study. Headache. 2012; 52:1456-70. Doi:10.1111/j.1526-4610.2012.02223.

4. Katsarava Z, Buse DC, Manack AN, Lipton RB. Defining the differences between episodic migraine and chronic migraine. Curr Pain Headache Rep. 2012,16:86-92. doi: 10.1007/s11916-011-0233-z.

5. Buse DC, Manack A, Serrano D, Turkel C, Lipton RB. Sociodemographic and comorbidity profiles of chronic migraine and episodic migraine sufferers. J Neurol Neurosurg Psychiatry. 2010; 81:428-32. doi: 10.1136/jnnp.2009.192492.

6. Linde M, Gustavsson A, Stovner LJ, Steiner TJ, Barré J, Katsarava Z, et al. The cost of headache disorders in Europe: the Eurolight project. Eur J Neurol. 2012;19:703-11. do 10.1111/j.1468-1331.2011.03612.xi

7. Stokes $M$, Becker WJ, Lipton RB, Sullivan SD, Wilcox TK, Wells L,et al. Cost of health care among patients with chronic and episodic migraine in Canada and the USA results from the International Burden of Migraine Study (IBMS). Headache: The J Head Face Pain. 2011;51:1058-77. doi: 10.1111/j.1526-4610.2011.01945.x.

8. Lanteri-Minet M. Economic burden and costs of chronic migraine. Curr Pain Headache Repor. 2014; 18:385. doi: 10.1007/s11916-013-0385-0.

9. Tassorelli C, Diener HC, Dodick DW, Silberstein SD, Lipton $\mathrm{RB}$, Ashina $\mathrm{M}$, et al. Guidelines of the International Headache Society for controlled trials of preventive treatment of chronic migraine in adults. Cephalalgia. 2018;38:815-32. doi: 10.1177/0333102418758283.

10. Serrano D, Lipton RB, Scher Al, Reed ML, Adams AM, Buse DC. Fluctuations in episodic and chronic migraine status over the course of 1 year: implications for diagnosis, treatment and clinical trial design. J Headache Pain. 2017;18:101. doi: 10.1186/s10194-017-0787-1.

11. May A, Schulte LH. Chronic migraine: risk factors, mechanisms and treatment. Nature Reviews Neurology. 2016; 12:455. doi: 10.1038/nrneurol.2016.93.

12. Carlsen LN, Munksgaard SB, Jensen RH, Bendtsen L. Complete detoxification is the most effective treatment of medication-overuse headache: a randomized controlled open-label trial. Cephalalgia. 2018; 38:225-36. doi: 10.1177/0333102417737779.

13. Katsarava Z, Schneeweiss $S$, Kurth $T$, Kroener U, Fritsche G, Eikermann A, Diener HC, Limmroth V. Incidence and predictors for chronicity of headache in patients with episodic migraine. Neurology. 2004; 62:788-90. doi: 10.1212/01. wnl.0000113747.18760.d2.

14. Direção Geral da Saúde. Normas Clínicas: Graus de Recomendação e Níveis de Evidência [consultado em 30/7/2020] Disponível em: https://www.dgs.pt/ficheirosde-upload-3/normas-clinicas-graus-de-recomendacao-eniveis-de-evidencia-pdf.aspx

15. Blumenfeld AM, Bloudek LM, Becker WJ, Buse DC, Varon SF, Maglinte GA, et al. Patterns of use and reasons for discontinuation of prophylactic medications for episodic migraine and chronic migraine: results from the second international burden of migraine study (IBMS-II). Headache. 2013;53:644-55. doi: 10.1111/head.12055.

16. Hepp Z, Dodick DW, Varon SF, Gillard P, Hansen RN, Devine EB. Adherence to oral migraine-preventive medications among patients with chronic migraine. Cephalalgia.
2015;35:478-88. doi: 10.1177/0333102414547138.

17. Hepp Z, Dodick DW, Varon SF, Chia J, Matthew N, Gillard $P$, et al. Persistence and switching patterns of oral migraine prophylactic medications among patients with chronic migraine: A retrospective claims analysis. Cephalalgia. 2017;37:470-85. doi: 10.1177/0333102416678382.

18. Diener HC, Bussone G, Van Oene JC, Lahaye M, Schwalen S, Goadsby PJ, TOPMAT MIG 201 (Top Chrome) Study Group. Topiramate reduces headache days in chronic migraine: A randomized, double blind, placebo controlled study. Cephalalgia. 2007; 27:814-23. doi: 10.1111/j.14682982.2007.01326.x.

19. Silberstein SD, Lipton RB, Dodick DW, Freitag FG, Ramadan $\mathrm{N}$, Mathew N, et al. Efficacy and safety of topiramate for the treatment of chronic migraine: A randomized, double blind, placebo controlled trial. Headache. 2007; 47:170-80. doi: 10.1111/j.1526-4610.2006.00684.x.

20. Silberstein S, Lipton R, Dodick D, Freitag F, Mathew N, Brandes J,et al. Topiramate treatment of chronic migraine: A randomized, placebo controlled trial of quality of life and other efficacy measures. Headache. 2009;49:1153-62. doi: 10.1111/j.1526-4610.2009.01508.x.

21. Diener HC, Dodick DW, Goadsby PJ, Bigal ME, Bussone $\mathrm{G}$, Silberstein SD,et al. Utility of topiramate for the treatment of patients with chronic migraine in the presence or absence of acute medication overuse. Cephalalgia. 2009; 29:1021-7. doi: 10.1111/j.1468-2982.2009.01859.x.

22. American Headache Society. The American Headache Society position statement on integrating new migraine treatments into clinical practice. Headache. 2019;59:1-8. doi: 10.1111/head.13456.

23. D'Amico D. Pharmacological prophylaxis of chronic migraine: a review of double-blind placebo-controlled trials. Neurol Sci. 2010; 31:23-8. doi: 10.1007/s10072-010-0268-7.

24. Silberstein SD, Dodick DW, Lindblad AS, Holroyd K, Harrington M, Mathew NT, et al. Randomized, placebo-controlled trial of propranolol added to topiramate in chronic migraine. Neurology. 2012; 78:976-84. doi: 10.1212/ WNL.0b013e31824d5846.

25. Aurora SK, Dodick DW, Turkel CC, DeGryse RE, Silberstein $\mathrm{SD}$, Lipton RB, et al. OnabotulinumtoxinA for treatment of chronic migraine: results from the double-blind, randomized, placebo-controlled phase of the PREEMPT 1 trial. Cephalalgia. 2010; 30:793-803. doi: 10.1177/0333102410364676.

26. Diener HC, Dodick DW, Aurora SK, Turkel CC, DeGryse RE, Lipton RB, et al. OnabotulinumtoxinA for treatment of chronic migraine: results from the double-blind, randomized, placebo-controlled phase of the PREEMPT 2 trial. Cephalalgia. 2010; 30:804-14. doi: 10.1177/0333102410364677.

27. Dodick DW, Turkel CC, DeGryse RE, Aurora SK, Silberstein SD, Lipton RB, Diener HC, Brin MF. OnabotulinumtoxinA for treatment of chronic migraine: Pooled results from the double blind, randomized, placebo controlled phases of the PREEMPT clinical program. Headache. 2010; 50:92136. doi: $10.1111 /$ j.1526-4610.2010.01678.x

28. Jackson JL, Kuriyama A, Hayashino Y. Botulinum toxin A for prophylactic treatment of migraine and tension headaches in adults: a meta-analysis. JAMA. 2012; 307:1736-45. doi: 10.1001/jama.2012.505.

29. Aurora SK, Dodick DW, Diener HC, DeGryse RE, Turkel CC, Lipton RB, Silberstein SD. OnabotulinumtoxinA for chronic migraine: efficacy, safety, and tolerability in patients who received all five treatment cycles in the PREEMPT clinical program. Acta Neurol Scand. 2014; 129:61-70. doi: 10.1111/ ane.12171.

30. Cernuda-Morollón E, Ramón C, Larrosa D, Alvarez R, Riesco N, Pascual J. Long-term experience with onabotulinumtoxinA in the treatment of chronic migraine: What happens after one year? Cephalalgia. 2015; 35:864-8. doi: 10.1177/0333102414561873.

31. Ahmed F, Gaul C, García-Moncó JC, Sommer K, Martelletti P. An open-label prospective study of the real-life use of 
onabotulinumtoxin A for the treatment of chronic migraine: the REPOSE study. J Headache Pain. 2019;20:26. doi: 10.1186/s10194-019-0976-1

32. Mathew NT, Jaffri SF. A double blind comparison of onabotulinumtoxina (BOTOX®) and topiramate (TOPAMAX®) for the prophylactic treatment of chronic migraine: A pilot study. Headache. 2009; 49:1466-78. doi: 10.1111/j.15264610.2009.01566.x

33. Silberstein SD, Blumenfeld AM, Cady RK, Turner IM, Lipton RB, Diener HCet al. OnabotulinumtoxinA for treatment of chronic migraine: PREEMPT 24-week pooled subgroup analysis of patients who had acute headache medication overuse at baseline. J Neurol Sci. 2013 15;331:48-56. doi 10.1016/j.jns.2013.05.003.

34. Silberstein SD, Dodick DW, Aurora SK, Diener HC, DeGryse RE, Lipton RB, Turkel CC. Per cent of patients with chronic migraine who responded per onabotulinumtoxinA treatment cycle: PREEMPT. J Neurol Neurosurg Psychiatry. 2015; 86:996-1001. doi: 10.1136/jnnp-2013-307149

35. NICE technology appraisal guidance 260 Botulinum toxin type $A$ for the prevention of headaches in adults with chronic migraine. [consultado em 30/7/2020] Disponível em https://www.nice.org.uk/guidance/ta260

36. Pijpers JA, Kies DA, Louter MA, van Zwet EW, Ferrari MD, Terwindt GM. Acute withdrawal and botulinum toxin $A$ in chronic migraine with medication overuse: a double-blind randomized controlled trial. Brain. 2019; 142:1203-14. doi: 10.1093/brain/awz052.

37. Gago-Veiga AB, Santos-Lasaosa S, Cuadrado ML, Guerrero ÁL, Irimia P, Láinez JM,et al. Evidencia y experiencia de bótox en migraña crónica: Recomendaciones para la práctica clínica diaria. Neurologia. 2019; 34: 408-17. doi: 10.1016/j. $\mathrm{nrl}$.2017.09.008

38. Bendtsen L, Sacco S, Ashina M, Mitsikostas D, Ahmed F, Pozo-Rosich P, Martelletti P. Guideline on the use of onabotulinumtoxinA in chronic migraine: a consensus statement from the European Headache Federation. J Headache Pain. 2018;19:91 doi: 10.1186/s10194-018-0921-8.

39. Edvinsson L, Haanes KA, Warfvinge K, Krause DN. CGRP as the target of new migraine therapies - successful translation from bench to clinic. Nat Rev Neurol. 2018;14:338-50. doi: 10.1038/s41582-018-0003-1.

40. Dodick DW, Lipton RB, Silberstein S, Goadsby PJ, Biondi D, Hirman J,et al. Eptinezumab for prevention of chronic migraine: A randomized phase $2 \mathrm{~b}$ clinical trial. Cephalalgia. 2019 ;39:1075-85. doi: 10.1177/0333102419858355.

41. Lipton R, Saper J, Ashina M, Biondi B, Bhattacharya S, Hirman J, et al. A phase 3, randomized, double-blind, placebocontrolled study to evaluate the efficacy and safety of eptinezumab for the preventive treatment of chronic migraine: results of the PROMISE-2 (Prevention Of Migraine via Intravenous eptinezumab Safety and Efficacy-2) trial. InPlatform presentation. American Academy of Neurology meeting, Los Angeles, CA 2018 Apr 24.

42. Tepper S, Ashina M, Reuter U, Brandes JL, Doležil D, Silberstein $\mathrm{S}$, et al. Safety and efficacy of erenumab for preventive treatment of chronic migraine: a randomised, double-blind, placebo-controlled phase 2 trial. Lancet Neurol. 2017;16:425-34. doi: 10.1016/S1474-4422(17)30083-2.

43. Silberstein SD, Dodick DW, Bigal ME, Yeung PP, Goadsby PJ, Blankenbiller T, et al. Fremanezumab for the Preventive Treatment of Chronic Migraine. $\mathrm{N}$ Engl J Med. 2017:377:2113-22. doi: 10.1056/NEJMoa1709038.

44. Detke HC, Goadsby PJ, Wang S, Friedman DI, Selzler KJ, Aurora SK. Galcanezumab in chronic migraine: the randomized, double-blind, placebo controlled REGAIN study. Neurology. 2018;91:e2211-21. doi: 10.1212/ WNL.0000000000006640.

45. Lipton RB, GandhiSK, Fitzgerald T, Yeung P P, Cohen JM, Yang $R$ et al. The positive impact of fremanezumab on work productivity and activity impairment in patients with chronic migraine. Procedings of the 60th Annual Scientific Meeting
American Headache Society. Headache. 2018;58(S2):61215. doi:10.1111/head.13306

46. Lipton RB, Goadsby PJ, Smith J, Schaeffler BA, Biondi DM, Hirman J,et al. Efficacy and safety of eptinezumab in patients with chronic migraine: PROMISE-2. Neurology. 2020;94: e1365-e1377. doi: 10.1212/WNL.0000000000009169.

47. Reuter U. A review of monoclonal antibody therapies and other preventative treatments in migraine. Headache. 2018; 58:48-59. doi: 10.1111/head.13302.

48. Tepper SJ, Diener HC, Ashina M, Brandes JL, Friedman DI, Reuter $U$, et al. Erenumab in chronic migraine with medication overuse: Subgroup analysis of a randomized trial. Neurology. 2019: 92:e2309-e2320. doi: 10.1212/ WNL.0000000000007497.

49. Ruff DD, Ford JH, Tockhorn-Heidenreich A, Sexson M, Govindan S, Pearlman EM, et al. Efficacy of galcanezumab in patients with chronic migraine and a history of preventive treatment failure. Cephalalgia. 2019: 39:931-44. doi: 10.1177/0333102419847957

50. Ashina M, Tepper S, Brandes JL, Reuter U, Boudreau G, Dolezil D,et al. Efficacy and safety of erenumab (AMG334) in chronic migraine patients with prior preventive treatment failure: a subgroup analysis of a randomized, double-blind, placebo-controlled study. Cephalalgia. 2018;38:1611-21. doi: 10.1177/0333102418788347

51. Sacco S, Bendtsen L, Ashina M, Reuter U, Terwindt G, Mitsikostas DD, et al. European headache federation guideline on the use of monoclonal antibodies acting on the calcitonin gene related peptide or its receptor for migraine prevention. J Headache Pain. 2019;201):6. doi: 10.1186/ s10194-018-0955-y.

52. Lipton RB, Brennan A, Palmer S, Hatswell AJ, Porter JK, Sapra S,et al. Estimating the clinical effectiveness and value-based price range of erenumab for the prevention of migraine in patients with prior treatment failures: a US societal perspective. J Med Econ 2018;21:666-675. doi: 10.1080/13696998.2018.1457533.

53. Förderreuther S, Zhang $Q$, Stauffer VL, Aurora SK, Láinez MJ. Preventive effects of galcanezumab in adult patients with episodic or chronic migraine are persistent: data from the phase 3, randomized, double-blind, placebo-controlled EVOLVE-1, EVOLVE-2, and REGAIN studies. J Headache Pain. 2018;19:121. doi: 10.1186/s10194-018-0951-2.

54. Camporeale A, Kudrow D, Sides R, Wang S, Van Dycke A, Selzler KJ,et al. A phase 3, long-term, open-label safety study of Galcanezumab in patients with migraine. BMC Neurol. 2018; 18:188. doi: 10.1186/s12883-018-1193-2.

55. Raffaelli B, Mussetto V, Israel H, Neeb L, Reuter U. Erenum$\mathrm{ab}$ and galcanezumab in chronic migraine prevention: effects after treatment termination. J Headache Pain.2019; 20:66. doi: 10.1186/s10194-019-1018-8.

56. Cohen JM, Dodick DW, Yang R, Newman LC, Li T, Aycardi E, Bigal ME. Fremanezumab as add on treatment for patients treated with other migraine preventive medicines. Headache. 2017;57:1375-84. doi: 10.1111/head.13156.

\section{Capitulo 4 - Cefaleia Tipo Tensão}

1. GBD 2015 Neurological Disorders Collaborator Group. Global, regional, and national burden of neurological disorders during 1990-2015: a systematic analysis for the Global Burden of Disease Study 2015. Lancet Neurol. 2017;16:87797. doi: 10.1016/S1474-4422(17)30299-5.

2. Headache Classification Committee of the International Headache Society (IHS). The International Classification of Headache Disorders, 3rd edition. Cephalalgia. 2018;38:1211. doi: 10.1177/0333102417738202

3. Pereira Monteiro J, Barros J, Esperança P, Fernandes G, GilGouveia R, Luzeiro I, et al. Classificação Internacional de Cefaleias - 3a Edição, Tradução Portuguesa. Sinapse. 2018; 18:1-172.

4. Bendtsen L, Evers S, Linde M, Mitsikostas DD, Sandrini G, Schoenen J, et al. EFNS guideline on the treatment 
of tension-type headache - report of an EFNS task force. Eur J Neurol. 2010;17:1318-25. doi: 10.1111/j.14681331.2010.03070.x

5. Lenaerts ME. Pharmacotherapy of tension-type headache (TTH). Expert Opin Pharmacother. 2009;10:1261-71. doi: 10.1517/14656560902942046.

6. Verhagen AP, Damen $L$, Berger MY, Lenssinck ML, Passchier J, Kroes BW. Treatment of tension type headache: paracetamol and NSAIDs work: a systematic review. Ned Tijdschr Geneeskd. 2010;154:A1924.

7. Stephens D, Derry S, Moore RA. Paracetamol (acetaminophen) for acute treatment of episodic tensiontype headache in adults. Cochrane Database Syst Rev. 2016;6:CD011889. doi: 10.1002/14651858.CD011889. pub2

8. Veys L, Derry S, Moore RA. Ketoprophen for episodic tension-type headache in adults. Cochrane Database Syst Rev. 2016;9:CD012190. doi: 10.1002/14651858.CD012190.pub2.

9. Migliardi JR, Armellino JJ, Friedman M, Gillings DB, Beaver WT. Caffeine as an analgesic adjuvant in tension headache. Clin Pharmacol Ther. 1994; 56:576-86. doi: 10.1038/ clpt.1994.179

10. Diener HC, Pfaffenrath V, Pageler L, Peil H, Aicher B. The fixed combination of acetylsalicylic acid, paracetamol and caffeine is more effective than single substances and dual combination for the treatment of headache: a multicentre, randomized, double-blind, single-dose, placebo-controlled parallel group study. Cephalalgia. 2005; 25:776-87. doi: 10.1111/j.1468-2982.2005.00948.x.

11. Cerbo R, Centonze V, Grazioli I, Tavolato B, Trenti T, Uslenghi $C$, et al. Efficacy of a fixed combination of indomethacin, prochlorperazine, and caffeine in the treatment of episodic tension-type headache: a double-blind, randomized, nimesulide-controlled, parallel group, multicentre trial. Eur J Neurol. 2005;12:759-67. doi: 10.1111/j.14681331.2005.01056.x.

12. Weinman D, Nicastro $O$, Akala $O$, Friedman BW. Parenteral treatment of episodic tension-type headache: a systematic review. Headache. 2014;54:260-8. doi: 10.1111/ head.12287.

13. Jackson JL, Mancuso JM, Nickoloff S, Berstein R, Kay C. Tricyclic and tetracyclic antidepressants for the prevention of frequent episodic or chronic tension-type headache in adults: a systematic review and meta-analysis. J Gen Intern Med. 2017;32:1351-8. doi: 10.1007/s11606-017-4121-z.

14. Fogelholm R, Murros K. Tizanidine in chronic tension-type headache: a placebo controlled double-blind cross-over study. Headache. 1992;32:509-13. doi: 10.1111/j.15264610. 1992.hed3210509.x

15. Spira PJ, Beran RG, Australian Gabapentin Chronic Daily Headache Group. Gabapentin in the prophylaxis of chronic daily headache: a randomized, placebo-controlled study. Neurology. 2003;61:1753-9. doi: 10.1212/01. wnl.0000100121.58594.11.

16. Moja PL, Cusi C, Sterzi RR, Canepari C. Selective serotonin re-uptake inhibitors (SSRIs) for preventing migraine and tension-type headaches. Cochrane Database Syst Rev. 2005;3:CD002919. doi: 10.1002/14651858.CD002919. pub2.

17. Lampl C, Marecek S, May A, Bendtsen L. A prospective, open-label, long-term study of the efficacy and tolerability of topiramate in the prophylaxis of chronic tension-type headache. Cephalalgia. 2006;26:1203-8. doi: 10.1111/j.1468-2982.2006.01193.x.

18. Banzi R, Cusi C, Randazzo C, Sterzi R, Tedesco D, Moja L. Selective serotonin reuptake inhibitors (SSRIs) and serotonin-norepinephrine reuptake inhibitors (SNRIs) for the prevention of tension-type headache in adults. Cochrane Database Syst Rev. 2015;4:CD002919. DOI: 10.1002/14651858. CD002919.pub3.

19. Karadas O, Inan LE, Ulas U, Odabasi Z. Efficacy of local lidocaine application on anxiety and depression and its curative effect on patients with chronic tension-type headache. Eur Neurol. 2013;70:95-101. doi: 10.1159/000350619.

20. Karadas O, Gul HL, Inan LE. Lidocaine injection of pericranial myofascial rigger points in the treatment of frequent episodic tension-type headache. J Headache Pain. 2013; 14:44. doi: 10.1186/1129-2377-14-44.

21. Jackson JL, Kuriyama A, Hayashino Y. Botulinum toxin A for prophylactic treatment of migraine and tension headaches in adults: a meta-analysis. JAMA. 2012;307:1736-45. doi: 10.1001/jama.2012.505.

22. Nestoriuc $Y$, Rief W, Martin A. Meta-analysis of biofeedback for tension-type headache: efficacy, specificity, and treatment moderators. J Consult Clin Psychol. 2008;76:379-96.

23. Chaibi A, Russell MB. Manual therapies for primary chronic headaches: a systematic review of randomized controlled trials. J Headache Pain. 2014;15:67. doi: 10.1037/0022006X.76.3.379.

24. France S, Bown J, Nowosilskyi M, Mott M, Rand S, Walters. Evidence for the use of dry needling and physiotherapy in the management of cervicogenic or tension-type headache: a systematic review. Cephalalgia. 2014;34:994-1003. doi: $10.1177 / 0333102414523847$.

25. Mesa-Jiménez JA, Lozano-López C, Angulo-Díaz-Parreño S, Rodríguez-Fernández ÁL, De-la-Hoz-Aizpurua JL, Fernández-de-Las-Peñas C. Multimodal manual therapy vs. pharmacological care for management of tension type headache: a meta-analysis of randomized trials. Cephalalgia. 2015;35: 1323-32. doi: 10.1177/0333102415576226.

26. Luedtke K, Allers A, Schulte LH, May A. Efficacy of interventions used by physiotherapists for patients with headache and migraine - systematic review and meta-analysis. Cephalalgia. 2016;36:474-92. doi: 10.1177/0333102415597889.

27. Madsen BK, Sogaard K, Andersen LL, Tornoe B, Jensen RH. Efficacy of strength training on tension-type headache: a randomised controlled study. Cephalalgia. 2018;38:1071. doi: $10.1177 / 0333102417722521$.

\section{Capitulo 5 - Cefaleias Trigémino-autonómicas}

1. Burish M. Cluster Headache and Other Trigeminal Autonomic Cephalalgias. Contin Minneap Minn. 2018;24:113756. doi:10.1212/CON.0000000000000625

2. Parreira E, Gil-Gouveia R, Pavão-Martins I. Cefaleia em salvas: fisiopatogenia, clínica e tratamento. Rev Port Clin Geral. 22:471-482.

3. Francis GJ, Becker WJ, Pringsheim TM. Acute and preventive pharmacologic treatment of cluster headache. Neurology. 2010;75:463-473. doi:10.1212/WNL.0b013e3181eb58c8

4. Evers S, Áfra J, Frese A. Cluster Headache and Other Trigemino-Autonomic Cephalgias. In: European Handbook of Neurological Management. London: John Wiley \& Sons, Ltd; 2010. p.179-190.

5. Petersen AS, Barloese MC, Lund NL, Jensen RH. Oxygen therapy for cluster headache. A mask comparison trial. A single-blinded, placebo-controlled, crossover study. Cephalalgia. 2017;37:214-24. doi:10.1177/0333102416637817

6. Schindler EAD, Wright DA, Weil MJ, Gottschalk $\mathrm{CH}$, Pittman BP, Sico JJ. Survey Analysis of the Use, Effectiveness, and Patient-Reported Tolerability of Inhaled Oxygen Compared With Injectable Sumatriptan for the Acute Treatment of Cluster Headache. Headache. 2018;58:1568-78. doi:10.1111/head.13405

7. Hoffmann J, May A. Diagnosis, pathophysiology, and management of cluster headache. Lancet Neurol. 2018;17:7583. doi:10.1016/S1474-4422(17)30405-2

8. Robbins MS, Starling AJ, Pringsheim TM, Becker WJ, Schwedt TJ. Treatment of Cluster Headache: The American Headache Society Evidence-Based Guidelines. Headache. 2016:56:1093-106. doi:10.1111/head.12866

9. Pageler L, Katsarava Z, Lampl C, Straube A, Evers S, Diener $\mathrm{HC}$, Limmroth V. Frovatriptan for prophylactic treatment of cluster headache: lessons for future trial design. Headache. 2011;51:129-34. doi:10.1111/j.1526-4610.2010.01772.x 
10. Ito $Y$, Mitsufuji T, Asano $Y$, Shimazu T, Kato $Y$, Tanahashi $N$, et al. Naratriptan in the Prophylactic Treatment of Cluster Headache. Intern Med Tokyo Jpn. 2017;56:2579-2582. doi:10.2169/internalmedicine.8865-17

11. Pascual J, Láinez MJA, Dodick D, Hering-Hanit R. Antiepileptic drugs for the treatment of chronic and episodic cluster headache: a review. Headache. 2007;47:81-9. doi:10.1111/j.1526-4610.2007.00653.x

12. Khan $S$, Olesen $A$, Ashina M. CGRP, a target for preventive therapy in migraine and cluster headache: Systematic review of clinical data. Cephalalgia Int J Headache. 2019;39:374-89. doi:10.1177/0333102417741297

13. Bardos JN, Goadsby PJ, Dodick D. A Placebo-Controlled Study of Galcanezumab in Patients with Episodic Cluster Headache: Results from the 8-Week Double-Blind Treatment Phase (Plen02.004). Neurology.2019;92(15Supplement).

14. Lampl C, Rudolph M, Bräutigam E. OnabotulinumtoxinA in the treatment of refractory chronic cluster headache. J Headache Pain. 2018;19. doi:10.1186/s10194-018-0874-y

15. Mitsikostas DD, Edvinsson L, Jensen RH, Katsarava Z, Lampl C, Negro A,et al. Refractory chronic cluster headache: a consensus statement on clinical definition from the European Headache Federation. J Headache Pain. 2014;15:79. doi:10.1186/1129-2377-15-79

16. Baraldi C, Pellesi L, Guerzoni S, Cainazzo MM, Pini LA. Therapeutical approaches to paroxysmal hemicrania, hemicrania continua and short lasting unilateral neuralgiform headache attacks: a critical appraisal. J Headache Pain. 2017;18. doi:10.1186/s10194-017-0777-3

17. Bujara S. Hemicrania Continua: Diagnosis and Treatment. Clinical Pain Advisor. [consultado em 30/7/2020] Disponível em: https://www.clinicalpainadvisor.com/home/topics/migraineheadache/hemicrania-continua-diagnosis-and-treatment/.

18. Prakash S, Rathore C, Rana K, Joshi H, Patel J, Rawat KS. A long-term prospective observational study in $31 \mathrm{pa}-$ tients with hemicrania continua. Cephalalgia Rep. 2019; 2:2515816318824694. doi:10.1177/2515816318824694

19. Moura LM, Bezerra JM, Fleming NR. Treatment of hemicrania continua: case series and literature review. Rev Bras Anestesiol. 2012;62:173-187. doi:10.1590/S003470942012000200004

20. Levy A, Matharu MS. Short-Lasting Unilateral Neuralgiform Headache Attacks. Ann Indian Acad Neurol. 2018;21: S31S38. doi:10.4103/aian.AIAN 356 17

\section{Capitulo 6 - Outras Cefaleias Primárias}

1. Starling A. Unusual headache disorders. Continuum. 2018; 24: 1192-208. doi: 10.1212/CON.0000000000000636.

2. Pascual J, González-Mandly A, Martín R, Oterino A. Headaches precipitated by cough, prolonged exercise or sexual activity: a prospective etiological and clinical study. J Headache Pain. 2008; 9:259 - 266. doi:10.1007/s10194-0080063-5.

3. Evers $\mathrm{S}$ et al. Treatment of rare other primary headaches recommendations of the German Migraine and Headache Society. Nervenheilkunde. 2005; 24: 217-26.

4. Wang SJ, Fuh JL, Lu SR. Benign cough headache is responsive to acetazolamide. Neurology. 2000; 55149 - 150. doi:10.1212/WNL.55.1.149

5. Raskin $\mathrm{NH}$. The cough headache syndrome: treatment. Neurology. 1995;45:1784

6. Allena M, Rossi P, Tassorelli C, errante E, Lisotto C, Nappi G. Focus on therapy of the Chapter IV headaches provoked by exertional factors: primary cough headache, primary exertional headache and primary headache associated with sexual activity. J Headache Pain 2010;11525 -530. doi:10.1007/s10194-010-0261-9.

7. Pascual J. Other primary headaches. Neurol Clin. 2009, 27:557 - 1. doi: 10.1016/j.ncl.2009.01.005.

8. Halker RB, Vargas BB. Primary exertional headache: updates in the literature. Curr Pain Headache Rep 2013;17:337. doi:10.1007/s11916-013-0337-8.
9. Frese A, Rahmann A, Gregor N, Biehl K, Husstedt IW, Evers S. Headache associated with sexual activity: prognosis and treatment options. Cephalalgia 2007;27: 1265 - 70. doi:10.1111/j.1468-2982.2007.01449.x

10. Lu SR, Liao YC, Fuh JL, Lirng JF, Wang SJ. Nimodipine for treatment of primary thunderclap headache. Neurology 2004, 62:1414-6. doi: 10.1212/01. wnl.0000120669.85649.77

11. Headache Classification Committee of the International Headache Society (IHS) The International Classification of Headache Disorders, 3rd edition. Cephalalgia. 2018; 38:1211. doi: $10.1177 / 0333102417738202$.

12. Krymchantowski AV. Headaches Due to External Compression Curr Pain Headache Rep. 2010;14:321-324. doi: 10.1007/s11916-010-0122-x.

13. Hagler S, Ballaban-Gil K, Robbins MS. Primary stabbing headache in adults and pediatrics: a review. Curr Pain Headache Rep. 2014; 18:450. doi: 10.1007/s11916-0140450-3

14. Pareja JA1, Sjaastad $O$. Primary stabbing headache. Handb Clin Neurol. 2010; 97:453-7. doi: 10.1016/S00729752(10)97039-5.

15. Chua AL, Nahas S. Ice Pick Headache. Curr Pain Headache Rep.2016; 20:30. doi: 10.1007/s11916-016-0559-7.

16. Piovesan EJ, Zukerman E, Kowacs PA, Werneck LC. Cox-2 inhib-itor for the treatment of primary stabbing headache secondary tocerebrovascular disease. Cephalalgia. 2002; 22:197. doi: 10.1046/j.1468-2982.2002.00346.x.

17. O'Connor MB, Murphy E, Phelan MJ, Regan MJ. Primary stabbing headache can be responsive to etoricoxib, a selective COX-2inhibitor. Eur J Neurol. 2008;15:e1. doi: 10.1111/j.1468-1331.2007.01962.x.

18. Franca Jr MC, Costa AL, Maciel Jr JA. Gabapentin responsive idiopathic stabbing headache. Cephalalgia. 2004; 24:993-6. doi: 10.1111/j.1468-2982.2004.00791.x.

19. Rozen TD. Melatonin as a treatment for idiopathic stabbing headache. Neurology. 2003;61:865-6. doi: 10.1212/01. wnl.0000082388.03466.e9.

20. Jacome DE (2001) Exploding head syndrome and idiopathic stabbing headache relieved by nifedipine. Cephalalgia. 21:617-618. doi: 10.1046/j.1468-2982.2001.00227.x.

21. Piovesan EJ, Teive HG, Kowacs PA, Da Silva LL, Werneck LC. Botulinum Neurotoxin type-A for primary stabbing headache. ArqNeuropsiquiatr. 2010; 68:212-5. doi: 10.1590/ s0004-282x2010000200011.

22. Schwartz DP, Robbins MS, Grosberg BM. Nummular headache update. Curr Pain Headache Rep. 2013; 17:340. doi: 10.1007/s11916-013-0340-0.

23. Pareja JA, Montojo T, Alvarez M. Nummular headache update. Curr Neurol Neurosci Rep. 2012; 12:118-24. doi: 10.1007/s11910-011-0247-2

24. Mathew NT, Kailasam J, Meadors L. Botulinum toxin type A for the treatment of nummular headache: four case studies. Headache. 2008; 48: 442-7. doi: 10.1111/j.15264610.2007.00960.x

25. Ruscheweyh R, Buchheister A, Gregor N. Nummular headache: six new cases and lancinating pain attacks as possible manifestation. Cephalalgia 2010; 30: 249-53 doi: 10.1111/j.1468-2982.2009.01893.x..

26. Martins IP, Abreu L. Nummular headache: Clinical features and treatment response in 24 new cases. Cephalalgia Rep. 2018; 1:1-8. doi:org/10.1177/2515816318802771.

27. Man YH, Yu TM, Li LS, Yao G, Mao XJ, Wu J. A new variant nummular headache: large diameter accompanied with bitrigeminal hyperalgesia and successful treatment with carbamazepine. Turk Neurosurg. 2012; 22:506-9. doi: 10.5137/1019-5149.JTN.3960-10.0.

28. Robbins MS, Grosberg BM. Menstrual-related nummular headache. Cephalalgia. 2010; 30:507-8. doi: 10.1111/j.1468-2982.2009.01947.x.

29. Tayeb Z, Hafeez F, Shafiq Q. Successful treatment of nummular headache with TENS. Cephalalgia. 2008; 28:897-8. 
doi: 10.1111/j.1468-2982.2007.01456.x.

30. Dai W, Yu S, Liang J, Zhang M. Nummular headache: peripheral or central? One case with reappearance of nummular headache after focal scalp was removed, and literature review. Cephalalgia. 2013; 33:390-7. doi: 10.1177/0333102412474504

31. Liang JF, Wang SJ. Hypnic headache: a review of clinical features, therapeutic options and outcomes. Cephalalgia. 2014; 34:795-805. doi: 10.1177/0333102414537914.

32. Diener HC, Obermann M, Holle D. Hypnic headache: clinical course and treatment. Curr Treat Options Neurol. 2012 14:15-26. doi: 10.1007/s11940-011-0156-3.

33. Lisotto C, Rossi P, Tassorelli C, Ferrante E, Nappi G. Focus on therapy of hypnic headache. J Headache Pain. 2010 Aug;11(4):349-54. doi: 10.1007/s10194-010-0227-y.

34. Dodick DW, Jones JM, Capobianco DJ. Hypnic headache: another indomethacin-responsive headache syndrome? Headache. 2000;40:830-5. doi: 10.1046/j.15264610.2000.00150.x.

35. Uniyal R, Paliwal VK, Anand S, Ambesh P. New daily persistent headache: An evolving entity. Neurol India. 2018 MayJun;66(3):679-687. doi: 10.4103/0028-3886.232291.

36. Robbins MS, Grosberg BM, Napchan U, Crystal SC, Lipton RB. Clinical and prognostic subforms of new daily persistent headache. Neurology. 2010;74:1358-64. doi: 10.1212/ WNL.0b013e3181dad5de.

37. Tyagi A. New daily persistent headache. Ann Indian Acad Neurol. 2012; 15: S62-S65. doi: 10.4103/09722327.100011.

38. Rozen TD. New daily persistent headache. Curr Pain Headache Rep. 2003; 7:218. doi: 10.1007/s11916-003-0076-3.

39. Goadsby PJ, Boes C. New daily persistent headache. J Neurol Neurosurg Psychiatry. 2002; 72 Suppl 2:ii6. doi: 10.1136/jnnp.72.suppl_2.ii6.

40. Mack KJ. New daily persistent headache in children and adults. Curr Pain Headache Rep. 2009; 13:47. doi: 10.1007/ s11916-009-0010-4.

41. Rozen TD. Successful treatment of new daily persistent headache with gabapentin and topiramate. Headache. 2002; 42:433. doi.org/10.1007/s11916-003-0076-3.

42. Riddle EJ, Smith JH. New Daily Persistent Headache: a Diagnostic and Therapeutic Odyssey. Curr Neurol Neurosci Rep. 2019;19:21. doi: 10.1007/s11910-019-0936-9.

43. Prakash $S$, Shah ND. Post-infectious new daily persistent headache may respond to intravenous methylprednisolone. J Headache Pain. 2010; 11:59-66. doi: 10.1007/s10194009-0171-x.

\section{Capitulo 7 - Nevralgia do Trigémeo}

1. Katusic S, Williams DB, Beard CM, Bergstralth EJ, Kurland LT. Epidemiology and clinical features of idiopathic trigeminal neuralgia and glossopharyngeal neuralgia: similarities and differences, Rochester, Minnesota, 1945-1984. Neuroepidemiology. 1991;10(5-6): 276-81. doi: 10.1159/000110284.

2. MacDonald BK, Cockerell OC, Sander JW, Shorvon SD. The incidence and lifetime prevalence of neurological disorders in a prospective community-based study in the UK. Brain. 2000;123:665-76. doi: 10.1093/brain/123.4.665.

3. Childs AM, Meacey JF, Ferrie CD, Holland PC. Neurovascular compression of the trigeminal and glossopharyngeal nerve: three case reports. Arch Dis Child. 2000;82:311-5. doi: 10.1136/adc.82.4.311.

4. Headache Classification Committee of the International Headache Society (IHS). The International Classification of Headache Disorders, 3rd edition. Cephalalgia. 2018;38:1-211.

5. Campbell FG, Graham JG, Zilkha KJ. Clinical trial of carbamazepine (Tegretol $®$ ) in trigeminal neuralgia. J Neurol Neurosurg Psychiatry. 1966;29:265-67. doi: 10.1136/ jnnp.29.3.265.

6. RockliffBW, DavisEH. Controlled sequential trials of carbamazepine in trigeminal neuralgia. Arch Neurol. 1966;15:129-36. doi: 10.1001/archneur.1966.00470140019003.
7. Killian JM, Fromm GH. Carbamazepine in the treatment of neuralgia. Use of side effects. Arch Neurol. 1968;19:129-36. doi: 10.1001/archneur.1968.00480020015001.

8. Nicol CF. A four-year double-blind study of Tegretol® in facial pain. Headache. 1969;9:54-7. doi: 10.1111/j.15264610.1969.hed0901054.x.

9. Gronseth G, Cruccu G, Alksne J, Argoff C, Brainin M, Burchiel $\mathrm{K}$, et al. Practice parameter: the diagnostic evaluation and treatment of trigeminal neuralgia (an evidence-based review): report of the Quality Standards Subcommittee of the American Academy of Neurology and the European Federation of Neurological Societies. Neurology. 2008;71:118390. doi: 10.1212/01.wnl.0000326598.83183.04.

10. Cruccu G, Gronseth G, Alksne J, Argoff C, Brainin M, Burchiel $\mathrm{K}$, et al. AAN-EFNS guidelines on trigeminal neuralgia management. Eur J Neurol. 2008;15:1013-28. doi: 10.1111/j.1468-1331.2008.02185.x

11. Bendtsen L, Zakrzewska JM, Abbot J, Braschinsky M, Di Stefano G, Donnet A, et al. European Academy of Neurology guideline on trigeminal neuralgia. Eur J Neurol. 2019;26:831-49. doi: 10.1111/ene.13950.

12. Beydoun A. Safety and efficacy of oxcarbazepine: results of randomized, double-blind trials. Pharmacotherapy. 2000;20:152S-158S. doi: 10.1592/phco.20.12.152s.35254.

13. Liebel JT, Menger N, Langohr H. Oxcarbazepine in der Behandlung der Trigeminusneuralgie. Nervenheilkunde. 2001; 15:461-65.

14. Di Stefano G, La Cesa S, Truini A, Cruccu G. Natural history and outcome of 200 outpatients with classical trigeminal neuralgia treated with carbamazepine or oxcarbazepine in a tertiary centre for neuropathic pain. J Headache Pain. 2014;15:34. doi: 10.1186/1129-2377-15-34.

15. Framm GH, Terrence CF, Chattha AS. Baclofen in the treatment of trigeminal neuralgia: double-blind study and longterm follow-up. Ann Neurol. 1984;15:240-4. doi: 10.1002/ ana.410150306.

16. Zakrzewska JM, Chaudhry Z, Nurmikko TJ, Patton DW, Mullens EL. Lamotrigine (Lamictal $®)$ in refractory trigeminal neuralgia: results from a double-blind placebo-controlled crossover trial. Pain. 1997;73:223-30. doi: 10.1016/s03043959(97)00104-8.

17. Zakrzewska JM, Linskey ME. Trigeminal neuralgia. BMJ Clin Evid. 2009;12;2009.

18. Cruccu G, Truini A. Refractory trigeminal neuralgia: nonsurgical treatment options. CNS Drugs. 2013; 27:91-6. doi: 10.1007/s40263-012-0023-0.

19. Hu Y, Guan X, Fan L, Li M, Liao Y, Nie Z, et al. Therapeutic efficacy and safety of botulinum toxin type $A$ in trigeminal neuralgia: a systematic review. J Headache Pain. 2013;14:72. doi: 10.1186/1129-2377-14-72.

20. Morra ME, Elgebaly A, Elmaraezy A, Khalil AM, Altibi A, Vu $T L$, et al. Therapeutic efficacy and safety of Botulinum Toxin A therapy in trigeminal neuralgia: a systematic review and meta-analysis of randomized controlled trials. J Headache Pain. 2016;17:63. doi: 10.1186/s10194-016-0651-8.

21. Chaudhry P, Friedman DI. Intravenous lidocaine treatment in classical trigeminal neuralgia with concomitant persistent facial pain. Headache. 2014;54:1376-79. doi: 10.1111/ head.12401.

22. Stavropoulou E, Argyra E, Zis P, Vadalouca A, Siafaka I. The effect of intravenous lidocaine on trigeminal neuralgia: a randomized double blind placebo controlled trial. ISRN Pain. 2014: ;2014:853826. doi: 10.1155/2014/853826.

23. Schnell S, Marrodan M, Acosta JN, Bonamico L, Goicochea MT. Trigeminal neuralgia crisis - intravenous phenytoin as acute rescue treatment. Headache. 2020;60:2247-53.

24. Jorns TP, Johnston A, Zakrzewska JM. Pilot study to evaluate the efficacy and tolerability of levetiracetam (Keppra) in treatment of patients with trigeminal neuralgia. Eur J Neurol. 2009;16:740-4. doi: 10.1111/j.1468-1331.2009.02585.x.

25. Mitsikostas DD, Pantes GV, Avramidis TG, Karageorgiou $\mathrm{KE}$, Gatzonis SD, Stathis PG, et al. An observational trial 
to investigate the efficacy and tolerability of levetiracetam in trigeminal neuralgia. Headache. 2010;50:1371-7. doi: 10.1111/j.1526-4610.2010.01743.x.

26. Coppola N, Calabria E, Fortuna G, Ruoppo E, Caparrotti $M$, Adamo D. Lacosamide in the treatment of trigeminal neuralgia refractory to conventional treatment due to severe leukopenia induced by anticonvulsivants. Proceedings. 2019;35:52. doi: 10.3390/proceedings2019035052.

27. Belliston S. Lacosamide efficacy in trigeminal neuralgia and other neuropathic pain syndromes: a case series. Neurology. 2019;92:P5.2-098.

28. Bennetto L, Patel NK, Fuller G. Trigeminal neuralgia and its management. BMJ. 2007;334:201-5. doi: 10.1136/ bmj.39085.614792.BE

29. Donnet A, Simon E, Cuny E, Demarquay G, Ducros A, De Gaalon $\mathrm{S}$, et al. French guidelines for diagnosis and treatment of classical trigeminal neuralgia (French Headache Society and French Neurosurgical Society). Neurochirurgie. 2018;64:285-302. doi: 10.1016/j.neuchi.2018.04.001.

Capitulo 8 - Cefaleia por Uso Excessivo de Medicamentos

1. Pereira Monteiro J, Barros J, Esperança P, Fernandes G, Gil-Gouveia R, Luzeiro I et al. Classificação Internacional de Cefaleias - $3^{a}$ Edição, Tradução Portuguesa. Sinapse. 2018;18:1-172.

2. Headache Classification Committee of the International Headache Society (IHS) The International Classification of Headache Disorders, 3rd edition. Cephalalgia. 2018;38:1 211. doi: $10.1177 / 0333102417738202$

3. Headache Classification Subcommittee of the International Headache Society. The International Classification of Headache Disorders: 2nd edition. Cephalalgia. 2004;24 Suppl 1:9-160. doi: 10.1111/j.1468-2982.2003.00824.x.

4. Pereira Monteiro J, Palmeira M, Barros J, Machado G, Machado J, Esperança $P$, et al. Classificação Internacional das Cefaleias, $2^{\text {a }}$ Edição - Tradução Portuguesa. Sinapse. 2005;5 (Suppl 1): 1-128

5. Limmroth V, Katsarava Z, Fritsche G, Przywara S, Diener $\mathrm{HC}$. Features of medication overuse headache following overuse of different acute headache drugs. Neurology. 2002;59:1011-4. doi:10.1212/WNL.59.7.1011

6. Westergaard ML, Hansen EH, Glümer C, Olesen J, Jensen $\mathrm{RH}$. Definitions of medication-overuse headache in population-based studies and their implications on prevalence estimates: A systematic review. Cephalalgia. 2014;34:40925. doi:10.1177/0333102413512033

7. Davies P. Medication overuse headache: A silent pandemic. Pain. 2012;153(1):7-8. doi:10.1016/j.pain.2011.10.021

8. Evers S, Marziniak M. Clinical features, pathophysiology, and treatment of medication-overuse headache. Lancet Neurol. 2010;9:391-401. doi:10.1016/S1474-4422(10)70008-9

9. Diener HC, Dodick D, Evers S, Holle D, Jensen RH, Lipton $\mathrm{RB}$, et al. Pathophysiology, prevention, and treatment of medication overuse headache. Lancet Neurol. 2019;18:891902. doi:10.1016/S1474-4422(19)30146-2

10. Bahra A, Walsh M, Menon S, Goadsby PJ. Does chronic daily headache arise de novo in association with regular use of analgesics? Headache. 2003;43:179-90. doi:10.1046/ j.1526-4610.2003.03041.x

11. Schmid CW, Maurer K, Schmid DM, Alon E, Spahn DR, Gantenbein $A R$, et al. Prevalence of medication overuse headache in an interdisciplinary pain clinic. J Headache Pain. 2013:14:4. doi:10.1186/1129-2377-14-4

12. Wilkinson SM, Becker WJ, Heine JA. Opiate use to control bowel motility may induce chronic daily headache in patients with migraine. Headache. 2001; 41:303. doi:10.1046/ j.1526-4610.2001.111006303.x

13. Evers $S$, Jensen R. Treatment of medication overuse headache - guideline of the EFNS headache panel. Eur J Neurol. 2011;18:1115-21. doi:10.1111/j.1468-1331.2011.03497.x

14. Katsarava Z, Fritsche G, Muessig M, Diener HC, Limmroth V. Clinical features of withdrawal headache following over- use of triptans and other headache drugs. Neurology. 2001:57:1694-8. doi:10.1212/WNL.57.9.1694

15. Chiang CC, Schwedt TJ, Wang SJ, Dodick DW. Treatment of medication-overuse headache: A systematic review. Cephalalgia. 2015;36:371-86. doi:10.1177/0333102415593088

16. Rossi P, Jensen R, Nappi G, Allena M. A narrative review on the management of medication overuse headache: The steep road from experience to evidence. J Headache Pain. 2009:10:407-417. doi:10.1007/s10194-009-0159-6

17. Munksgaard SB, Madsen SK, Wienecke T. Treatment of medication overuse headache - A review. Acta Neurol Scand. 2019;139:405-14. doi:10.1111/ane.13074

18. Russell MB, Lundqvist $C$. Prevention and management of medication overuse headache. Curr Opin Neurol. 2012;25:290-5. doi:10.1097/WCO.0b013e328352c431

19. de Goffau MJ, Klaver ARE, Willemsen MG, Bindels PJE, Verhagen AP. The Effectiveness of Treatments for Patients With Medication Overuse Headache: A Systematic Review and Meta-Analysis. J Pain. 2017;18:615-27. doi:10.1016/j. jpain.2016.12.005

20. Zeeberg P, Olesen J, Jensen R. Discontinuation of medication overuse in headache patients: Recovery of therapeutic responsiveness. Cephalalgia. 2006;26:1192-8. doi:10.1111/ j.1468-2982.2006.01190.x

21. Carlsen LN, Munksgaard SB, Jensen RH, Bendtsen L. Complete detoxification is the most effective treatment of medication-overuse headache: A randomized controlled open-label trial. Cephalalgia. 2018;38:225-36. doi:10.1177/0333102417737779

22. Rossi P, Faroni JV, Tassorelli C, Nappi G. Advice alone versus structured detoxification programmes for complicated medication overuse headache $(\mathrm{MOH})$ : a prospective, randomized, open-label trial. J Headache Pain. 2013;14:10. doi:10.1186/1129-2377-14-10

23. Zed PJ, Loewen PS, Robinson G. Medication-induced headache: Overview and systematic review of therapeutic approaches. Ann Pharmacother. 1999;33:61-72. doi:10.1345/ aph.18184

24. Hernández-Díaz S, García Rodríguez LA. Steroids and risk of upper gastrointestinal complications. Am J Epidemiol. 2001; 153(11):1089. doi:10.1093/aje/153.11.1089

25. Diener HC, Haab J, Peters C, Ried S, Dichgans J, Pilgrim A. Subcutaneous Sumatriptan in the Treatment of Headache During Withdrawal From Drug Induced Headache. Headache. 1991;31(4):205. doi:10.1111/j.1526-4610.1991. hed3104205.x

26. Raskin $\mathrm{NH}$. Repetitive intravenous dihydroergotamine as therapy for intractable migraine. Neurology. 1986; 36(7):995. doi:10.1212/wnl.36.7.995

27. Ford RG, Ford KT. Continuous intravenous dihydroergotamine in the treatment of intractable headache. Headache. 1997; 37(3):129. doi:10.1046/j.1526-4610.1997.3703129.x

28. J.A. C, P. VD. Outpatient home-based continuous intravenous dihydroergotamine therapy for intractable migraine. Headache. 2010;50(5):852

29. Silberstein SD, Schulman EA, Hopkins MMF. Repetitive Intravenous DHE in the Treatment of Refractory Headache. Headache J Head Face Pain. 1990;30(6):334. doi:10.1111/j.1526-4610.1990.hed3006334.x

30. Schwartz TH, Karpitskiy V V., Sohn RS. Intravenous valproate sodium in the treatment of daily headache. Headache. 2002; 42(6):519. doi:10.1046/j.1526-4610.2002.02127.x

31. Mitsikostas DD, Paemeleire K. Pharmacological Management of Headaches.; Springer International Publishing Switzerland 2016. doi:10.1007/978-3-319-19911-5

32. Mei D, Ferraro D, Zelano $G$, et al. Topiramate and triptans revert chronic migraine with medication overuse to episodic migraine. Clin Neuropharmacol. 2006:29:269-75. doi:10.1097/01.WNF.000022888.49044.99

33. Diener HC, Dodick DW, Goadsby PJ, et al. Utility of topiramate for the treatment of patients with chronic migraine in the presence or absence of acute medication overuse. 
Cephalalgia. 2009. doi:10.1111/j.1468-2982.2009.01859.x

34. Rizzato B, Leone G, Misaggi G, Zivi I, Diomedi M. Efficacy and tolerability of pregabalin versus topiramate in the prophylaxis of chronic daily headache with analgesic overuse: an open-label prospective study. Clin Neuropharmacol. 2011. doi:10.1097/wnf.0b013e318210ecc9

35. Sarchielli $P$, Messina P, Cupini LM, Tedeschi G, Di Piero V, Livrea $P$, et al. Sodium valproate in migraine without aura and medication overuse headache: A randomized controlled trial. Eur Neuropsychopharmacol. 2014; 24(8): 128997. doi:10.1016/j.euroneuro.2014.03.010

36. EUCTR2007-006773-92-IT. Sodium Valproate in the treatment of medication overuse headache: a controlled randomized clinical trial. - SAMOHA. Http://www.who.int/trialsearch/trial2.aspx? Trialid=euctr2007-006773-92-it. 2008.

37. Diener HC, Dodick DW, Goadsby PJ, Bigal ME, Bussone $G$, et al. Utility of topiramate for the treatment of patients with chronic migraine in the presence or absence of acute medication overuse. Cephalalgia. 2009;29:1021-7. doi: 10.1111/j.1468-2982.2009.01859.x.

38. Sandrini G, Perrotta A, Tassorelli C. Botulinum toxin type - A in the prophylactic treatment of medication-overuse headache: A multicenter, double-blind, randomized, placebo-controlled, parallel group study. J Headache Pain. 2011;12:427-33. doi:10.1007/s10194-011-0339-z

39. Pijpers JA, Kies DA, Louter MA, Van Zwet EW, Ferrari MD, Terwindt GM. Acute withdrawal and botulinum toxin $A$ in chronic migraine with medication overuse: A double-blind randomized controlled trial. Brain. 2019;142:1203-14. doi:10.1093/brain/awz052

40. Paemeleire K, Crevits I, Goadsby PJ, Kaube H. Practical management of medication-overuse headache. Acta neurol Belg. 2006;106:43-51. doi:10.1586/14737175.7.9.1145

41. Silberstein SD, Blumenfeld AM, Cady RK, Turner IM, Lipton $\mathrm{RB}$, Diener HC, et al. OnabotulinumtoxinA for treatment of chronic migraine: PREEMPT 24-week pooled subgroup analysis of patients who had acute headache medication overuse at baseline. J Neurol Sci. 2013;331:48-56. doi: 10.1016/j.jns.2013.05.003.

42. Tepper SJ, Diener HC, Ashina M, Brandes JL, Friedman $\mathrm{DI}$, Reuter $\mathrm{U}$, et al. Erenumab in chronic migraine with medication overuse: Subgroup analysis of a randomized trial. Neurology. 2019;92:e2309-e2320. doi: 10.1212/ WNL.0000000000007497.

43. Tepper SJ, Diener H-C, Ashina M, Brandes JL, Friedman $\mathrm{DI}$, Reuter $U$ et al. Erenumab in chronic migraine with medication overuse: Subgroup analysis of a randomized trial. Neurology. 2019;92(20): e2309.doi: 10.1212/ WNL.0000000000007497

44. Silberstein SD, Cohensup JM, Bibeausup K, Seminerio MJ. The impact of fremanezumab on medication overuse in patients with chronic migraine. Ann Neurol Conf 143rd Annu Meet Am Neurol Assoc ANA 2018 United states. 2018.

45. Dodick DW, Doty EG, Aurora SK, Ruff DD, Stauffer VL, Jedynak $\mathrm{J}$ et al. Medication Overuse in a subgroup Analysis of Phase 3 Placebo-controlled Studies of Galcanezumab in the Prevention of Episodic and Chronic Migraine. Cephalalgia. $2021 ; 41(3): 340$. doi: 10.1177/0333102420966658

46. Vandenbussche N, Laterza D, Lisicki M, Lloyd J, Lupi C, Tischler H. Medication-overuse headache: a widely recognized entity amidst ongoing debate. J Headache Pain. 2018;19. doi:10.1186/s10194-018-0875-x

47. Westergaard ML, Munksgaard SB, Bendtsen L, Jensen RH. Medication-overuse headache: a perspective review. Ther Adv Drug Saf. 2016;7:147-58. doi:10.1177/2042098616653390

Capitulo 9 - Situações Particulares

Capitulo 9.1 - Recomendações Terapêuticas das Cefaleias Primárias na População Pediátrica

1. Kacperski J, Kabbouche MA, O'Brien HL, Weberding JL. The optimal management of headaches in children and adolescents. Ther Adv Neurol Disord. 2016;9:53-68. doi:
$10.1177 / 1756285615616586$.

2. Headache Classification Committee of the International Headache Society (IHS) The International Classification of Headache Disorders, 3rd edition. Cephalalgia. 2018;38:1211. doi: $10.1177 / 0333102417738202$.

3. Lewis DW, Winner P, Wasiewski W The placebo responder rate in children and adolescents. Headache. 2005;45:232. doi: 10.1111/j.1526-4610.2005.05050.x.

4. Soee AB, Skov L, Skovgaard LT, Thomsen LL. Headache in children: Effectiveness of multidisciplinary treatment in a tertiary pediatric headache clinic. Cephalalgia. 2013; 33:1218-1228. doi: 10.1177/0333102413490349.

5. Farello G, Ferrara P, Antenucci A, Basti C, Verrotti A. The link between obesity and migraine in childhood: a systematic review. Ital J Pediatr. 2017;43-27. doi: 10.1186/s13052-017-0344-1.

6. Eidlitz Markus T, Toldo I. Obesity and migraine in childhood. Curr Pain Headache Rep. 2018; 22:42. doi: 10.1007/ s11916-018-0696-2.

7. Kenney EL, Long MW, Cradock AL, Gortmaker SL. Prevalence of Inadequate Hydration Among US Children and Disparities by Gender and Race/Ethnicity: National Health and Nutrition Examination Survey, 2009-2012. Am J Public Health 2015;105:113-8. doi: 10.2105/AJPH.2015.302572

8. Paruthi S, Brooks LJ, D'Ambrosio C, Hall WA, Kotagal S, Lloyd RM, et al. Recommended Amount of Sleep for Pediatric Populations: A Consensus Statement of the American Academy of Sleep Medicine. J Clin Sleep Med. 2016;12:785-6. doi: 10.5664/jcsm.5866..

9. Hamalainen M L, Hoppu K, Valkeila E,Santavuori P. Ibuprofen or acetaminophen for the acute treatment of migraine in children: a double-blind study. Neurology.1997;48:103-7. doi: 10.1212/wnl.48.1.103

10. Lewis DW, Kellstein D, Dahl G, Burke B, Frank LM, Toor S, et al. Children's Ibuprofen suspension for the acute treatment of pediatric migraine. Headache.2002;42:780-786. doi: 10.1046/j.1526-4610.2002.02180.x.

11. Pugliese A, Beltram $T$ and Torre D. Reye and Reye like syndromes. Cell Biochem Funct. 2008;26:741-746. doi: 10.1002/cbf.1465.

12. Sheridan DC, Laurie A, Pacheco $S, F u$, Hansen ML, Ma OJ, et al. Relative Effectiveness of Dopamine Antagonists for Pediatric Migraine in the Emergency Department. Pediatr Emerg Care. 2018;34:165-168. doi: 10.1097/ PEC. 0000000000000718 .

13. Kanis JM, Timm NL. Chlorpromazine for the treatment of migraine in a pediatric emergency department. Headache. 2014;54:335-342. doi: 10.1111/head.12255.

14. Richer $L$, Billinghurst $L$, Linsdell MA, Russell $K$, Vandermeer $B$, Crumley ET,et al. Drugs for the acute treatment of migraine in children and adolescents. Cochrane Database Syst Rev. 2016;19: CD005220). doi: 10.1002/14651858. CD005220.pub2

15. Barbanti P, Grazzi L, Egeo G. Pharmacotherapy for acute migraines in children and adolescents. Expert Opin Pharmacother. 2019;20:455-63. doi: 10.1080/14656566.2018.1552941.

16. Derosier FJ, Lewis D, Hershey AD, Winner PK, Pearlman E, Rothner $A D$, et al. Randomized trial of sumatriptan and naproxen sodium combination in adolescent migraine. Pediatrics. 2012;129:1411-20. doi: 10.1542/peds.2011-2455.

17. Winner $P$, Linder $S$, Hershey AD. Consistency of response to sumatriptano/Naproxen sodium in a randomized placebocontrolled, cross-over study for the acute treatment of migraine in adolescence. Headache. 2015; 55:519-528. doi: 10.1111/head.12555.

18. MacDonald JT. Treatment of juvenile migraine with subcutaneous sumatriptan. Headache 1994;34:581-582. doi: 10.1111/j.1526-4610.1994.hed3410581.x.

19. Linder SL. Subcutaneous sumatriptan in the clinical setting: the first 50 consecutive patients with acute migraine in a pediatric neurology office practice. Headache.1996;36:419-422. doi: 10.1046/j.1526-4610.1996.3607419.x. 
20. Brousseau DC, Duffy SJ, Anderson AC, Linakis JG. Treatment of pediatric migraine headache: a randomized, double-blind trial of prochlorperazine versus ketorolac Ann Emerg Med.2004;43:256-262. doi: 10.1016/s01960644(03)00716-9.

21. Sheridan D, Sun $B, O$ Brien and Hansen M. Intravenous sodium valproate for acute pediatric headache. J Emerg Med.2015; 49.541-454. doi: 10.1016/j.jemermed.2015.02.024

22. Reiter PD, Nickisch J, Merritt G. Efficacy and tolerability of intravenous valproic acid in acute adolescent migraine. Headache. 2005;45:899-903. doi: 10.1111/j.15264610.2005.05158.x.

23. Eapen A, SivaswamyL, Agarwal R, Sivaswamy L. Management os pediatric migraine in a tertiary care versus community based emergency department: observational pilot study. Pediatr Neurol. 2014; 50:164-170. doi: 10.1016/j. pediatrneurol.2013.10.005

24. Sheridan DC, Meckler GD. Inpatient Pediatric Migraine Treatment: Does Choice of Abortive Therapy Affect Length of Stay? J Pediatr.2016;179:211-215. doi: 10.1016/j. jpeds.2016.08.050.

25. Gelfand AA, Qubty W, Goadsby PJ. Pediatric migraine prevention-first do no harm. JAMA Neurol. 2017;74:893-894. DOI: 10.1001/jamaneurol.2017.1011

26. Forsythe WI, Gillies D, Sills MA. Propranolol in the treatment of childhood migraine. Dev Med Child Neurol. 1984;26:737. doi: 10.1111/j.1469-8749. 1984.tb08166.x.

27. Olness K, MacDonald JT, Uden DL. Comparison of selfhypnose and propranolol in the treatment of juvenile classic migraine. Pediatrics 1987; 79:593

28. Ludvigsson J. Propranolol used in prophylaxis of migraine in children. Acta Neurol Scand 1974;50:109).

29. El-Chammas K, Keyes J, Thompson N, v. Pharmacologic treatment of pediatric headaches:a meta-analysis. JAMA Pediatr. 2013; 167:250. doi: 10.1001/jamapediatrics.2013.508.

30. Powers SW, Coffey CS, Chamberlin LA, Ecklund DJ, Klingner EA, Yankey JW, et al. Trial of Amitriptyline, Topiramate, and Placebo for Pediatric Migraine. N Eng J Med. 2017; 376:115. doi: 10.1056/NEJMoa1610384.

31. Le K, Yu D, Wang J, Ali Al, Guo Y. Is topiramate effective for migraine prevention in patients less than 18 years of age? A meta-analysis of randomized controlled trials. J Headache Pain. 2017;18:69. doi: 10.1186/s10194-017-0776-4.

32. Lewis D, Winner P, Saper J, Ness S, Polverejan E, Wang S, et al. Randomized, double-bind, placebo-controlled study to evaluate the eficacy and safety of topiramate for migraine prevention in pediatric subjects 12 to 17 years of age. Pediatrics. 2009;123:924-34. doi: 10.1542/peds.2008-0642.

33. Lewis D, Ashwal S, Hershey A, Hirtz D, Yonker M, Silberstein S; American Academy of Neurology Quality Standards Subcommittee; Practice Committee of the Child Neurology Society.Practical parameter: pharmacological treatment of migraine headache in children and adolescents: report of the American Academy of Neurology Quality Standards Subcommittee and the Practice Committee of the Child Neurology Society. Neurology. 2004;63:2215-24. doi: 10.1212/01.wnl.0000147332.41993.90

34. Apostl G, Chuy JA, Cedermark K, Robieson WZ, Olson E, Abi-Saab WM, et al. Divalproex extended release in adolescent migraine prophylaxis: results of a randomized, double-bind, placebo-controlled study. Headache 2008; 48:1012. doi: 10.1111/j.1526-4610.2008.01081.x.

35. Belman A, Milazo M, Savatic M, Gabis L. Gabapentin for migraine prophylaxis in children (abstract). Ann Neurol. 2001; 50: S109.

36. Miller GS. Efficacy and safety of levetiracetam in pediatric migraine. Headache. 2004; 44:238. doi: 10.1111/j.15264610.2004.04053.x

37. Le K, Yu D, Wang J, Ali Al, Guo Y. Is topiramate effective for migraine prevention in patients less than 18 years of age? A meta-analysis of randomized controlled trials. J Headache Pain. 2017;18:69. doi: 10.1186/s10194-017-0776-4.

38. Tso AR, Goadsby PJ. Anti-CGRP monoclonal antibodies: the next era of migraine prevention? Curr. Treat.Options Neurol. 2017;19:2. doi: 10.1007/s11940-017-0463-4.

39. Szperka CL, VanderPluym J, Orr SL, Oakley CB, Qubty W, Patniyot I, et al. Recommendations on the use of AntiCGRP monoclonal antibodies in children and adolescents. Headache. 2018; 581658-69. doi: 10.1111/head.13414.

40. Orr SL, Venkateswaran S. Nutraceuticals in the prophylaxis of pediatric migraine: Evidence-based review and recomendations. Cephalalgia. 2014; 34:568. doi: 10.1177/0333102413519512.

41. Sherwood M, Goldman RD. Effectiveness of riboflavin in pediatric migraine prevention. Can Fam Phys. 2014; 60:24

42. Miano S, Parisi P, Pelliccia A, Luchetti $A$, Paolino MC, Villa MP. Melatonin to prevent migraine or tension-type headache in children. Neurol Sci. 2008;29:285-7. doi: 10.1007/ s10072-008-0983-5.

43. Fallah R, Shoroki FF, Ferdosian F. Safety and efficacy of melatonin in pediatric migraine prophylaxis. Curr Drug Saf. 2015; 10:132-5, doi: 10.2174/1574886309666140605114614

44. Fisher E, Law E, Dudeney J, Palermo TM, Stewart G, Eccleston C. Psychological therapies for the management of chronic and recurrent pain in children and adolescents. Cochrane Database Syst Rev. 2018;9:CD003968. doi: 10.1002/14651858.CD003968.pub5.

45. Kroon Van Diest AM, Ernst MM, Vaughn L. CBT for Pediatric Migraine: a qualitative study of patient and parents experience. Headache.2018;58:661-75. doi: 10.1111/head.13285. Epub 2018 Mar 8

46. Hicks $\mathrm{CL}$, von Baeyer $\mathrm{CL}$, McGrath PJ. Online psychological treatment for pediatric recurrent pain: a randomized evaluation. J Paediatr Psychol. 2006;31: 724-736.doi: 10.1093/ jpepsy/jsj065

47. Stubberud A, Varkey E, McCrory DC, Pedersen SA, Linde M. Biofeedback as Prophylaxis for Pediatric Migraine: A Meta-analysis. Pediatrics. 2016;138:e20160675. doi: 10.1542/peds.2016-0675.

48. Gelfand AA, Gallagher RC. Cyclic vomiting syndrome versus inborn errors of metabolism: a review with clinical recommendations. Headache 2016:56:215-21. doi: 10.1111/ head.12749.

49. Irwin S., Barmherzig R, Gelfand A. Recurrent gastrointestinal disturbance: abdominal migraine and cyclic vomiting syndrome. Curr Neurol Neurosci Rep. 2017;17:21. doi: 10.1007/s11910-017-0731-4

50. Andersen JM, Sugerman KS, Lockhart JR, Weinberg WA. Effective prophylactic therapy for cyclic vomiting syndrome in children using amitriptyline or cyproheptadine. Pediatrics. 1997;100:977. doi: 10.1542/peds.100.6.977.

51. Kumar N, Bashar Q, Reddy N, Sengupta J, Ananthakrishnan A, Schroeder A, et al. Cyclic Vomiting Syndrome (CVS): is there a difference based on onset of symptoms--pediatric versus adult? BMC Gastroenterol. 2012;12:52. doi: 10.1186/1471-230X-12-52.

52. Orr SL, Kabbouche MA, O'Brien HL, Kacperski J, Powers SW, Hershey AD. Paediatric migraine: evidence-based management and future directions. Nat Rev Neurol. 2018;14:515-27. doi: 10.1038/s41582-018-0042-7.

53. Packman B, Packman E, Doyle G, Cooper S, Ashraf E, Koronkiewicz K, et al. Solubilized ibuprofen: evaluation of onset, relief, and safety of a novel formulation in the treatment of episodic tension-type headache. Headache. 2000:40:561. doi: 10.1046/j.1526-4610.2000.00087.x.

54. Tornoe B, Madsen BK, Andersen LL, Skotte JH, Jensen R, Jensen $C$, et al. Specific strength training compared with interdisciplinary counseling for girls with tension-type headache: A randomized controlled trial. J Pain Res. 2016; 9:257-70. doi: 10.2147/JPR.S97826. eCollection 2016.

55. Bruijn J, Duivenvoorden H, Passchier J, Locher H, Dijkstra $\mathrm{N}$, Arts WF. Medium-dose riboflavin as a prophylactic agent 
in children with migraine: a preliminary placebo-controlled randomised, double-blind, cross-over trial. Cephalalgia. 2010;30:1426-34. doi: 10.1177/0333102410365106.

56. Miano S, Parisi P, Pelliccia A, Luchetti A, Paolino MC, Villa MP. Melatonina to prevent migraine or tension type headache in children. Neurol Sci. 2008;29:285-7. doi: 10.1007/ s10072-008-0983-5.

57. Mack KJ, Goadsby P. Trigeminal Autonomic Cephalalgia in Children and Adolescents: Cluster headache and related conditions. Semin Pediatr Neurol. 2016; 22:23-6. doi: 10.1016/j.spen.2015.08.002.

58. Mariani R, Capuano A, Torriero R, Tarantino S, Properzi E, Vigevano $\mathrm{F}$ et al. Cluster headache in childhood: case series from a pediatric headache center. J Child Neurol 2014;29:625. doi: 10.1177/0883073812470735.

59. Lambru G, Matharu M. Management of trigeminal autonomic cephalgias in children and adolescents. Curr Pain Headache Rep.2013;17:323. doi: 10.1007/s11916-0130323-1.

60. Raieli V,Eliseo M, Pandolfi E, La Vecchia M, La Franca G, Puma $D$, et al. Recurrent and chronic headachein cildren below 6 years of age. J Headache Pain. 2005;6:125-42. doi: 10.1007/s10194-005-0168-z. Epub 2005 May 13.

61. Silva-Néto RP, Almeida KJ. Hypnic headache in chilhood: a literature review. J Neurol Sci. 2015;356:45-48. doi: 10.1016/j.jns.2015.06.048.

62. Bigal ME, Lipton RB, Tepper SJ, Rapoport AM, Sheftell FD. Primary chronic daily headache and its subtypes in adolescentes and adults. Neurology. 2004;63:843-7. doi: 10.1212/01.wnl.0000137039.08724.18.

63. Sezer T, Kandemir H, Alehan F. A randomized trial comparing amitriptyline versus topiramate for the prophylaxis of chronic daily headache in pediatric patients.Int $\mathrm{J}$ Neurosci.2013;123:553-6. doi: 10.3109/00207454.2013.776048.

64. Shah S, Calderon MD, Wu W, Grant J, Rinehart J. Onabotulinumtoxin A (BOTOX®) for Prophylactic Treatment of Pediatric Migraine: A Retrospective Longitudinal Analysis. J Child Neurol. 2018;33:580-6. doi: 10.1177/0883073818776142. Epub 2018 Jun 7.

65. Gelfand AA, Reider AC, Goadsby PJ. Outcomes of greater occipital nerve injections in pediatric patients with chronic primary headache disorders. Pediatr Neurol. 2014; 50:1359. doi: 10.1016/j.pediatrneurol.2013.09.008.

66. Puledda F, Goadsby PJ, Prabhakar P. Treatment of disabling headache with greater occipital nerve injections in a large population of childhood and adolescent patients: a service evaluation. J Headache Pain. 2018;19:5. doi: 10.1186/ s10194-018-0835-5.

67. Soee AB, Skov L, Skovgaard LT, Thomsen LL. Headache in children: effectiveness of multidisciplinary treatment in a tertiary paediatric headache clinic. Cephalalgia. 2013;33:1218-28. doi: 10.1177/0333102413490349.

68. Sahai-Srivastava S, Sigmman E, Uyeshiro Simon A, Cleary L, Ginoza L. Multidisciplinary Team Treatment Approaches to Chronic Daily Headaches. Headache. 2017; 57:1482-91. doi: 10.1111/head.13118. Epub 2017 Jul 25.

69. Hickman C, Jacobson D, Melnyk BM. Randomized controlled trial of the acceptability, feasibility, and preliminary effects of a cognitive behavioral skills building intervention in adolescents with chronic daily headaches: a pilot study. J Pediatr Health Care. 2015; 29:5-16. doi: 10.1016/j.pedhc.2014.05.001.

70. Powers SW, Kashikar-Zuck SM,Allen JR, LeCates SL, Slater SK, Zafar M et al. Cognitive behavioral therapy plus amitriptyline for chronic migraine in children and adolescents: a randomized clinical trial. JAMA. 2013; 310:2622-30. doi: 10.1001/jama.2013.282533.

71. Kroner JW, Hershey AD, Kashikar-Zuck SM, LeCates SL, AIlen JR, Slater SK, et al. Cognitive Behavioral Therapy plus Amitriptyline for Children and Adolescents with Chronic Migraine Reduces Headache Days to $\leq 4$ per Month. Headache. 2016;56:711-6. doi: 10.1111/head.12795.
72. Kroon Van Diest AM, Ramsey RR, Kashikar-Zuck S, Slater S, Hommel K, et al. Treatment Adherence in Child and Adolescent Chronic Migraine Patients: Results From the Cognitive-Behavioral Therapy and Amitriptyline Trial. Clin J Pain. 2017;33:892-98. doi: 10.1097/AJP.0000000000000481.

73. Law EF, Beals-Erickson SE, Noel M, Claar R, Palermo TM. Pilot Randomized Controlled Trial of Internet-Delivered Cognitive -Behavioral Treatment for Pediatric Headache. Headache. 2015; 55:1410-1425. doi: 10.1111/head.12635.

74. Coeytaux RR, Befus D. Role of Acupuncture in the Treatment or Prevention of Migraine, Tension-Type Headache, or Chronic Headache Disorders. Hedache. 2016;56:123840. doi: $10.1111 /$ head.12857.

75. Shiri S, Feintuch U, Weiss N, Pustilnik A, Geffen T, Kay B, et al. A virtual reality system combined with biofeedback for treating pediatric chronic headache--a pilot study. Pain Med.2013;14:621-7. doi: 10.1111/pme.12083.

76. Kohen,D.P.Chronic daily headache: Helping adolescentes help themselves with self-hipnosis. Am.J. Clin. Hypn.2011;54,32-46. doi: 10.1080/00029157.2011.566767.

Capitulo 9.2 - Recomendações Terapêuticas das Cefaleias Primárias nas Mulheres em Fase Fértil, Gravidez, Amamentação e Menopausa

1. M1. Marcus DA, Bain PA. Effective Migraine Treatment in Pregnant and Lactating Women: A Practical Guide. New York: Springer New ;2009.

2. Afridi, SK. Migraine : navigating the hormonal minefield. Pract. Neurol. 2020; 20(2):115-121. doi: 10.1136/practneurol-2019-002332.

3. Allais, G., Chiarle, G., Sinigaglia, S. \& Benedetto, C. Menstrual migraine: a review of current and developing pharmacotherapies for women. Expert Opinion on Pharmacotherapy 2018 ; 19(2):123-136. doi: 10.1080/14656566.2017.1414182.

4. Sader, E. \& Rayhill, M. Headache in Pregnancy, the Puerperium, and menopause. Semin. Neurol. 2018 ;38(6):627-633. doi: 10.1055/s-0038-1673681.

5. INFARMED. BOLETIM DE FARMACOVIGILANCIA. https://www.infarmed.pt/documents/15786/1277078/ bf5-2-2trim2001.pdf/f0c5c60a-fbe 3-4655-b06003e1fdf620bb?version=1.1.

6. Dennerstein L, Morse C, Burrows G, Oats J, Brown J, Smith M. Menstrual migraine: A double-blind trial of percutaneous estradiol. Gynecol. Endocrinol. 1988; 2(2):113-20.doi: 10.3109/09513598809023619.

7. MacGregor, E. A., Frith, A., Ellis, J., Aspinall, L. \& Hackshaw, A. Prevention of menstrual attacks of migraine: A double-blind placebo-controlled crossover study. Neurology 2006 26; 67(12): 2159-63.doi: 10.1212/01. wnl.0000249114.52802.55

8. Almén-Christensson, A., Hammar, M., Lindh-Åstrand, L., Landtblom, A. M. \& Brynhildsen, J. Prevention of menstrual migraine with perimenstrual transdermal 17--estradiol: $A$ randomized, placebo-controlled, double-blind crossover study. Fertil. Steril. 2011; 96(2): 498-500.e1. doi: 10.1016/j. fertnstert.2011.05.089.

9. Sacco S, Merki-Feld GS, AEgidius KL, Bitzer J, Canonico M, Gantenbein $A R$, et al. Effect of exogenous estrogens and progestogens on the course of migraine during reproductive age: a consensus statement by the European Headache Federation (EHF) and the European Society of Contraception and Reproductive Health (ESCRH). J Headache Pain. 2018;19(1):76. doi: 10.1186/s10194-018-0896-5.

10. Sacco S, Merki-Feld GS, ÆEgidius KL, Bitzer J, Canonico M, Kurth $T$ et al . Hormonal contraceptives and risk of ischemic stroke in women with migraine: a consensus statement from the European Headache Federation (EHF) and the European Society of Contraception and Reproductive Health (ESC). J Headache Pain. 2017 30;18(1):108. doi: 10.1186/ s10194-017-0815-1. Erratum in: J Headache Pain. $2018 \mathrm{Sep}$ 10;19(1):81 . 
11. Bussiere, J. L., Dvies R, Dean C, Xu C, Kim KH, Vargas HM et al. Nonclinical safety evaluation of erenumab, a CGRP receptor inhibitor for the prevention of migraine. Regulatory Toxicology and Pharmacology 2019 Aug;106:224-238.doi: 10.1016/j.yrtph.2019.05.013.

12. EMA. Galcanezumab Product Information . disponível em https://www.ema.europa.eu/en/documents/product-information/emgality-epar-product-information_en.pdf.

13. EMA. Fremanezumab Product Information . disponível em https://www.ema.europa.eu/en/documents/product-information/ajovy-epar-product-information_en.pdf

14. Contag S A, Mertz H L, Bushnell CD. Migraine during pregnancy: Is it more than a headache? Nature Reviews Neurology 2009 5(8):449-56.doi: 10.1038/nrneurol.2009.100.

15. Amundsen S, Nordeng H, Nezvalová-Henriksen K, Stovner LJ, Spigset O. Pharmacological treatment of migraine during pregnancy and breastfeeding. Nat Rev Neurol. 2015 Apr;11(4):209-19. doi: 10.1038/nrneurol.2015.29.

16. Negro A, Delaruelle Z, Ivanova TA, Khan S, Ornello R, Raffaelli $\mathrm{B}$, et al ; Headache and pregnancy: a systematic review. J Headache Pain. 2017 ;18(1):106. doi: 10.1186/ s10194-017-0816-0.

17. Centers for Disease Control (CDC). Use of folic acid for prevention of spina bifida and other neural tube defects-1983-1991. MMWR Morb Mortal Wkly Rep. 1991; 40(30):513-6. PMID: 2072886.

18. González-García N, Díaz de Terán J, López-Veloso $A C$, Mas-Sala N, Mínguez-Olaondo A, Ruiz-Piñero $M$ et al. Headache: pregnancy and breastfeeding Recommendations of the Spanish Society of Neurology's Headache Study Group. Neurologia. 2019. 29:S0213-4853(19)30009-X.. doi: 10.1016/j.nrl.2018.12.003.

19. T19. Taylor LG, Bird ST, Sahin L, Tassinari MS, Greene P, Reichman ME, et al Antiemetic use among pregnant women in the United States: the escalating use of ondansetron. Pharmacoepidemiol Drug Saf. 2017 ;26(5):592-596. doi: $10.1002 /$ pds.4185.

20. Marcus D. A. Managing headache during pregnancy and lactation. Expert Review of Neurotherapeutics 2008 Mar;8(3):385-95. doi: 10.1586/14737175.8.3.385.

21. Hutchinson $S$, Marmura MJ, Calhoun A, Lucas $S$, Silberstein $\mathrm{S}$, Peterlin BL. Use of common migraine treatments in breast-feeding women: a summary of recommendations. Headache. 2013 ; 53(4):614-27. doi: 10.1111/head.12064.

22. Calhoun $A H$, Peterlin BL. Treatment of cluster headache in pregnancy and lactation. Curr Pain Headache Rep. 2010; 14(2):164-73. doi: 10.1007/s11916-010-0102-1.

23. Singh HJ, Saleh HI, Gupalo S, Omar E. Effect of melatonin supplementation on pregnancy outcome in Wistar-Kyoto and Sprague-Dawley rats. Sheng Li Xue Bao. 2013 Apr 25;65(2):149-57.

24. B.P. Management of Trigeminal Neuralgia During Pregnancy. In: Rath G. (eds) Handbook of Trigeminal Neuralgia. Springer, Singapore.2019. pp 223-229.

Capitulo 9.3 - Tratamento das Cefaleias em Pessoas Idosas e com Comorbilidades

1. Ozge A. Chronic daily headache in the elderly. Curr Pain Headache Rep 2013; 17: 382. doi: 10.1007/s11916-0130382-3.

2. Starling AJ. Diagnosis and Management of Headache in Older Adults. Mayo Clin Proc. 2018; 93:252-62. doi: 10.1016/j.mayocp.2017.12.002.

3. Ward TN. Headache Disorders in the Elderly. Curr Treat Options Neurol. 2002;4: 403-8. doi: 10.1007/s11940-002-0051-z.
4. de Rijk P, Resseguier N, Donnet A. Headache Characteristics and Clinical Features of Elderly Migraine Patients. Headache. 2018; 58: 525-33. doi: 10.1111/head.13247. Epub 2017 Dec 13

5. Coxib and traditional NSAID Trialists' (CNT) Collaboration, Bhala N, Emberson J, Merhi A, Abramson S, Arber N, et al. Vascular and upper gastrointestinal effects of non-steroidal anti-inflammatory drugs: meta-analyses of individual participant data from randomised trials. Lancet. 2013 Aug 31;382(9894):769-79. doi: 10.1016/S0140-6736(13)60900-9.

6. Semenov IA. Headache in the elderly. Dis Mon. 2015 ;61:249-50. doi: 10.1016/j.disamonth.2015.03.009.

7. Generis Farmacêutica, S.A., Resumo das Características do Medicamento de ADT. Revisto em abril de 2018.

8. AstraZeneca Produtos Farmacêuticos, L., Resumo das Características do Medicamento de Inderal. Aprovado em setembro de 2017.

9. Sanofi - Produtos Farmacêuticos, L., Resumo das Características do Medicamento de Priadel. Aprovado em março de 2018.

10. Janssen-Cilag Farmacêutica, L., Resumo das Características do Medicamento de Topamax. Aprovado em dezembro de 2015.

11. Ireland, A.P., Resumo das Características do Medicamento de Botox. Aprovado em março de 2017.

12. Laboratórios Pfizer, L., Resumo das Características do Medicamento de Efexor XR. Aprovado em junho de 2016.

13. Abbott Laboratórios, L., Resumo das Características do Medicamento de Isoptin. Aprovado em dezembro de 2010.

14. Bravo TP. Headaches of the elderly. Curr Neurol Neurosci Rep. 2015;15:30. doi: 10.1007/s11910-015-0552-2.

Capitulo 10 - Interações Farmacológicas no Tratamento das Cefaleias

1. Ansari H, Ziad S. Drug-Drug Interactions in Headache Medicine. Headache. 2016; 56: 1241-8. doi: 10.1111/ head.12864. Epub 2016 Jun 28.

2. Lionetto L, Borro M, Curto M, Capi M, Negro A, Cipolla F, et al. Choosing the safest acute therapy during chronic migraine prophylactic treatment: pharmacokinetic and pharmacodynamic considerations. Expert Opin Drug Metab Toxicol. 2016;12: 399-406. doi: 10.1517/17425255.2016.1154042.

3. Prakash S, Adroja B, Parekh H. Serotonin syndrome in patients with headache disorders. BMJ Case Rep. 2017 ;2017:bcr2017221383. doi: 10.1136/bcr-2017-221383.

4. Pomes LM, Guglielmetti M, Bertamino E, Simmaco M, Borro $M$, Martelletti P.Optimising migraine treatment: from drugdrug interactions to personalized medicine.J Headache Pain. 2019; 20 : 56-68. doi: 10.1186/s10194-019-1010-3.

5. RCMs e EPARs dos medicamentos citados. Disponível em: https://extranet.infarmed.pt/INFOMED-fo/pesquisa-avancada.xhtml

6. Ritter JM. Individual variations, pharmacogenomics and personalized medicine. In: Rang and Dale's Pharmacology. Amsterdam: Elsevier; 2020. p. 152-62.

7. Robbins MS, Lipton RB. Management of headache in the elderly. Drugs Aging. 2010; 27: 377-98.

8. Rolan PE. Drug interactions with triptans: which are clinically significant? CNS Drugs. 2012; 26: 949-57.

9. Tepper SJ. Drug interactions in Headache: What to Watch for and Why, American Migraine Foundation, 2008. consultado em 7/05/2021, disponível em https://americanmigrainefoundation.org/resource-library/drug-interactions-inheadache-what-to-watch-for-and-why/ 


\section{Instruções aos Autores e Políticas Editoriais}

\section{Instruções aos Autores}

\section{Língua}

O título, resumo e palavras-chave, devem ser apresentados em inglês e português.

Os manuscritos submetidos à SINAPSE devem ser claramente escritos em português (de Portugal) e/ou inglês de nível razoável.

\section{Copyright}

Todos os artigos nesta revista são de Acesso Aberto e atendem aos requisitos das agências de financiamento ou instituições académicas. Relativamente à utilização por terceiros a SINAPSE rege-se pelos termos da licença Creative Commons 'Atribuição - Uso Não-Comercial - Proibição de Realização de Obras Derivadas (cc-by-nc-nd)'.

É da responsabilidade do autor obter permissão para reproduzir ilustrações, tabelas, etc. de outras publicações.

Após a aceitação de um artigo, os autores serão convidados a preencher um "Publishing Agreement". Será enviado um e-mail ao autor correspondente, confirmando a recepção do manuscrito juntamente com um formulário de Publishing Agreement ou um link para a versão online desse contrato.

\section{Auto-Arquivo}

Os autores ficam autorizados a disponibilizar os seus artigos em repositórios das suas instituições de origem, desde que mencionem sempre onde foram publicados e de acordo com a licença Creative Commons.

\section{Taxa de Processamento do Artigo}

Não há taxa de processamento de artigo.

\section{Conduta Ética e Direitos Humanos e Animais}

Os autores devem assegurar que o estudo que submetem para publicação está em conformidade com os princípios éticos e legais, quer no decurso da investigação quer na publicação, nomeadamente com as recomendações da Declaração de Helsínquia revistas em 2013 da Associação Médica Mundial (http:// www.wma.net/en/20activities//Oethics/IOhelsinki), do International Committee of Medical Journal Editors (www.icmje.org) e do Committee on Publication Ethics (COPE) (http://publicationethics.org/resources/guidelines). Nos casos adequados, os autores devem demonstrar que a investigação foi aprovada pela comissão de ética das instituições envolvidas e que as recomendações foram seguidas. Esta informação deve constar no texto do artigo. Qualquer suspeita de má conduta será investigada e denunciada. Não se devem apresentar imagens, nomes, números de processos clínicos ou outros elementos que permitam a identificação dos participantes no estudo. Os estudos que envolvam experiências em animais devem ser conduzidos em conformidade com as guidelines definidas no "Guide for the care and use of laboratory animals" dos National Institutes of Health. Todos os estudos em animais deverão igualmente obedecer às guidelines ARRIVE (Animal Research: Reporting of In Vivo Experiments). Os autores deverão ainda consultar a legislação vigente a nível nacional que regula este tipo de estudos (Decreto Lei n. ${ }^{\circ}$ | 13/2013 de 7/08/2013, e eventuais actualizações posteriores). Deve ser claramente explicitado no manuscrito que as normas acima referidas foram seguidas.

\section{Privacidade e Consentimento Informado}

Estudos em doentes ou voluntários requerem aprovação da comissão de ética e consentimento informado escrito, o que deve ser documentado no artigo. Os autores são responsáveis por obter o consentimento informado relativamente a cada indivíduo presente em fotografias, vídeos, descrições detalhadas, mesmo após tentativa de ocultar a respectiva identidade. Nomes, iniciais ou outras formas de identificação devem ser removidos das fotografias ou outras imagens. Devem ser omitidos dados pessoais, como profissão ou residência, excepto quando sejam cientificamente relevantes para o trabalho. Os autores devem assegurar que não apresentam dados que permitam identificação inequívoca ou, caso isso não seja possível, devem obter o consentimento informado dos intervenientes (ou, quando aplicável, do tutor ou representante legalmente definido).

\section{Permissões}

Todo o material previamente publicado e protegido por direitos autorais, incluindo ilustrações, figuras e tabelas, deve ser acompanhado de permissão escrita para reprodução dos detentores dos direitos autorais.

\section{Conflito de Interesse e Fontes de Financiamento}

Existe um conflito de interesses quando o julgamento profissional sobre um interesse primário (como o bem-estar dos doentes ou a validade da investigação) pode ser influenciado por um interesse secundário (como ganho financeiro).

As relações financeiras são os conflitos de interesse mais facilmente identificáveis e têm maior probabilidade de prejudicar a credibilidade da revista, dos autores e da própria ciência. No entanto, os conflitos podem ocorrer por outros motivos, como relacionamentos pessoais ou rivalidades, competição académica e crenças intelectuais.

Todos os participantes do processo de revisão por pares e publicação - não apenas autores, mas também revisores, editores e membros do conselho editorial da SINAPSE - devem considerar os seus conflitos de interesse ao cumprir as suas funções no processo de revisão e publicação do artigo e devem divulgar todos os relacionamentos que possam ser vistos como potenciais conflitos de interesse.

Os autores devem referir todas as fontes de financiamento ao estudo descrito e a sua influência na concepção do manuscrito ou na decisão de submissão para publicação. O rigor e a exactidão dos conteúdos, assim como as opiniões expressas são da exclusiva responsabilidade dos autores.

Os autores são obrigados a divulgar todas as relações financeiras e pessoais que possam enviesar o trabalho. Para prevenir ambiguidade, os autores têm que explicitamente mencionar se existe ou não conflitos de interesse. Todos os autores devem completar e submeter o modelo de Declaração de Conflitos de Interesse (ICMJE Form for Disclosure of Potential Conflicts of Interest), disponível em http://www.icmje.org/conflicts-of-interest/. Essa informação será mantida confidencial durante a revisão do manuscrito pelos revisores e não influenciará a decisão editorial, mas será publicada se o artigo for aceite. Se não existirem conflitos, os autores devem mencionar esse facto.

\section{Resultados de ensaios clínicos}

A SINAPSE apoia iniciativas que contribuam para uma melhor divulgação de resultados ensaios clínicos. Estas incluem o registo prospectivo de ensaios clínicos em bases de dados públicas adequadas. De acordo com as recomendações do ICMJE, a SINAPSE exige o registo de todos os ensaios clínicos cujos dados sejam incluídos em trabalhos submetidos para publicação nesta revista.

O ICMJE adopta a definição da Organização Mundial de Saúde de ensaio clínico, que é "qualquer estudo de investigação que prospectivamente atribua a participantes humanos, individualmente ou em grupo, uma ou mais intervenções relacionadas com a saúde, com o objectivo de avaliar os seus resultados relacionados com a saúde". Esta definição inclui ensaios das fases I a IV. O ICMJE define intervenções relacionadas com a saúde como "qualquer intervenção usada para modificar um resultado biomédico ou relacionado com a saúde" e resultados relacionados com a saúde como "qualquer medida biomédica ou relacionada com a saúde obtida em doentes ou participantes”.

\section{Registo de ensaios clínicos}

O registo numa base de dados pública de ensaios clínicos é condição necessária para a publicação de dados de ensaios clínicos na SINAPSE, de acordo com as recomendações do ICMJE (http://www.icmje.org). Os ensaios devem ser registados anteriormente ou no início do período de recrutamento de doentes. Os estudos puramente observacionais (aqueles em que a atribuição de uma intervenção médica não é do critério do investigador) não exigem registo.

O número de registo do ensaio clínico (TRN) bem como a data desse registo devem ser referidos no final do resumo do artigo. 


\section{Disponibilização dos dados}

A SINAPSE sugere que todos os dados nos quais se baseiam as conclusões de um artigo de investigação original sejam disponibilizados para os leitores. Sugere-se assim aos autores que assegurem que os seus dados ficam disponíveis em repositórios públicos (sempre que estes estejam disponíveis e sejam adequados), que sejam apresentados no manuscrito principal ou em arquivos adicionais, sempre que possível em formato tratável (por exemplo, em folha de cálculo e não em pdf).

A SINAPSE exige uma declaração de disponibilização dos dados, presente no final de cada manuscrito. Para ensaios de fármacos ou dispositivos médicos, a declaração deve referir, pelo menos, que os dados relevantes de cada doente, devidamente anonimizados, estão disponíveis mediante pedido justificado aos autores.

Sugerem-se formulações para a referida declaração:

"Disponibilização dos dados: os dados individuais dos doentes [e/ou] o conjunto completo de dados [e/ou] o anexo técnico [e/ou] as especificações da análise estatística, estão disponíveis em [/doi] [com acesso livre/ com as restrições] [do autor correspondente em]. Os participantes deram o seu consentimento informado para disponibilização de dados [ou... não foi obtido consentimento dos participantes, mas os dados apresentados estão anonimizados e o risco de identificação é reduzido... ou não foi obtido consentimento dos participantes, mas os benefícios potenciais da disponibilização destes dados justificam os prejuízos potenciais, uma vez que ....]"

Se os dados não estiverem disponíveis, deve ser referido o seguinte: "Disponibilização dos dados: não estão disponíveis dados adicionais."

Esta opção não se aplica a ensaios clínicos de fármacos ou dispositivos médicos.

Pode ser solicitado aos autores que disponibilizem os dados brutos em que basearam o seu artigo durante o processo de revisão e até 10 anos após a publicação.

\section{Submissão dos Trabalhos}

A submissão de um manuscrito implica que o trabalho descrito não tenha sido publicado previamente (excepto na forma de um resumo ou como parte de uma palestra publicada ou de uma tese académica), e que não está sendo considerado para publicação noutra revista, que o manuscrito foi aprovado por todos os autores e, tácita ou explicitamente, pelas autoridades competentes onde o trabalho foi realizado e que, se for aceite para publicação, não será publicada em outro lugar na mesma forma, em inglês ou em qualquer outra língua, incluindo electronicamente.

Todos os manuscritos devem ser acompanhados por uma carta de apresentação. Deve ser dada garantia na carta de apresentação de que o manuscrito não está sob consideração simultânea por qualquer outra revista. $\mathrm{Na}$ carta de apresentação, os autores devem declarar seus potenciais conflitos de interesse e fornecer uma declaração sobre a autoria.

Para verificar a originalidade, o artigo pode ser verificado pelo serviço de detecção de originalidade.

As submissões que não estejam em conformidade com estas instruções podem ser devolvidas para reformulação e reenvio.

\section{Submissão do Manuscrito}

Os manuscritos são submetidos através do site da SINAPSE em http:// www.SINAPSE.pt

\section{Contacto}

Em caso de dúvidas durante a submissão, contacte: sinapse.spn@gmail.com

Preparação do Manuscrito

\section{Uso de programa de processamento de texto}

É importante que o arquivo seja guardado no formato nativo do processador de texto usado. O texto deve estar no formato de coluna única. Mantenha o layout do texto o mais simples possível.

Para evitar erros desnecessários, aconselhamos o uso das funções "verificação ortográfica" e "verificação gramatical" do seu processador de texto.

\section{Tipologia dos Artigos}

A SINAPSE aceita artigos das seguintes tipologias:

a) Artigos Originais reportando investigação clínica ou básica (ensaios clínicos, estudos de coorte, estudos de caso-controlo, outros estudos observacionais);

b) Artigos de Revisão

c) Revisões Sistemáticas com ou sem Meta-Análise; d) Estudos de Caso/Casos Clínicos;

e) Imagens em Neurologia;

f) Editoriais, que são escritos a convite do Editor-Chefe e consistem em comentários sobre artigos publicados na revista ou sobre temas de relevância particular;

g) Cartas ao Editor, que consistem em opiniões concisas sobre artigos recentemente publicados na SINAPSE;

h) Perspectivas:

i) Guidelines;

Na secção de submissão:

I. Título

Título em português e inglês, conciso, especifico e informativo, sem abreviaturas e não excedendo os 120 caracteres. $O$ título pode incluir um complemento de título com um máximo de 40 caracteres (incluindo espaços).

\section{Autores e afiliações}

Na secção da autoria, liste o Nome de todos os Autores (primeiro e último nome) e respectivas afiliações (serviço, instituição, cidade, país) e grau académico mais elevado.

\section{Financiamento}

Todos as fontes de financiamento, no domínio público ou privado,, incluindo bolsas, que contribuíram para a realização do trabalho.

\section{Autor Correspondente}

Indicar claramente quem vai lidar com a correspondência em todas as fases de arbitragem e publicação, também pós-publicação. Indicar endereço postal e e-mail do Autor responsável pela correspondência relativa ao manuscrito.

\section{Resumo e Keywords}

Um resumo conciso e factual é requerido, capaz de representar isoladamente o conteúdo do artigo, escrito em português e inglês. Nenhuma informação que não conste no manuscrito pode ser mencionada no resumo. O resumo não pode remeter para o texto, não podendo conter citações nem referências a figuras.

No fim do resumo devem ser incluídas um máximo de 5 keywords em inglês utilizando a terminologia que consta no Medical Subject Headings (MeSH), https://meshb.nlm.nih.gov/search

\section{Resumo Estruturado}

Um resumo estruturado, com as etiquetas de secção apropriadas (Introdução, Métodos, Resultados e Conclusão), deve fornecer o contexto e objectivo do estudo, procedimentos básicos (selecção dos sujeitos de estudo ou animais de laboratório, métodos observacionais e analíticos), principais resultados (significância estatística, se possível) e principais conclusões. Deve enfatizar aspectos novos e importantes do estudo ou das observações.

VII. Os autores também deverão anexar a declaração de "Protecção de pessoas e animais", Confidencialidade dos dados e consentimento informado e Conflitos de interesse.

\section{Prémios e Apresentações prévias}

Devem ser referidos os prémios e apresentações do estudo, prévias à submissão do manuscrito.

\section{Texto}

\section{Artigos Originais}

Os artigos originais devem incluir as seguintes secções: Introdução, Material e Métodos, Resultados, Discussão e Conclusão, Agradecimentos (se aplicável), Referências, Tabelas e Figuras.

Os artigos originais não devem exceder 4000 palavras, até 6 tabelas ou figuras e até 60 referências. Um resumo estruturado com o máximo de 350 palavras.

Seguir as guidelines EQUATOR

Article structure

\section{Introduction}

State the objectives of the work and provide an adequate background, avoiding a detailed literature survey or a summary of the results.

\section{Material and methods}

Provide sufficient detail to allow the work to be reproduced. Methods already published should be indicated by a reference: only relevant modifications should be described.

Results

Results should be clear and concise. 


\section{Discussion}

This should explore the significance of the results of the work, not repeat them. A combined Results and Discussion section is often appropriate. Avoid extensive citations and discussion of published literature.

\section{Conclusion}

The main conclusions of the study may be presented in a short Conclusions section, which may stand alone or form a subsection of a Discussion or Results and Discussion section.

\section{Artigos de Revisão Narrativa}

Os artigos de revisão são artigos abrangentes que sintetizam ideias pré-existentes e sugerem novas. Abrangem áreas amplas.

O foco deve ser uma actualização sobre a compreensão actual da etiologia ou fisiopatologia das doenças, considerações diagnósticas e terapêutica.

Essas revisões devem abordar uma questão ou questão específica relevante para a prática clínica. Embora geralmente por convite do Editor-Chefe, a SINAPSE aceita ocasionalmente artigos de revisão não solicitados sobre assuntos importantes ou sobre avanços recentes. Antes de submeter uma revisão, pedimos que envie ao Editor-Chefe um breve esboço (não mais de 500 palavras) indicando a importância do assunto, e por que está qualificado para escrevê-lo. Um convite para submissão não garante aceitação.

Os artigos de revisão não devem exceder 4000 palavras, até 6 tabelas ou figuras e até 100 referências. Um resumo não estruturado com o máximo de 350 palavras.

\section{Revisões Sistemáticas e Meta-Análises}

As revisões sistemáticas podem ou não utilizar métodos estatísticos (meta-análises) para analisar e resumir os resultados dos estudos incluídos.

As Revisões Sistemáticas podem ser apresentadas no formato Introdução, Métodos, Resultados, Discussão. $\mathrm{O}$ assunto deve ser claramente definido. O objectivo de uma revisão sistemática deve ser produzir uma conclusão baseada em evidências. Nos Métodos deve ser fornecida uma indicação clara da estratégia de pesquisa da literatura, extracção de dados, classificação das evidências e análise. Deve ser seguida a normativa PRISMA ( $h t t p: / / w w w$. prisma-statement.org/) e realizado o registo do protocolo na PROSPERO (https://www.crd.york.ac.uk/prospero).

O texto não deverá exceder 4000 palavras, excluindo um resumo estruturado (máximo de 350 palavras). Não poderá incluir mais de 100 referências, e até 6 tabelas ou figuras.

\section{Caso Clínico}

O relato de Casos Clínicos deve incluir as seguintes seções: Introdução, Caso Clínico e Discussão.

O texto não poderá exceder 2000 palavras, e não poderá exceder as 25 referências bibliográficas. Deve incluir um resumo não estruturado que não exceda 150 palavras.

Deve ser seguida a normativa CARE (http://www.care-statement.org/).

Tendo em conta a sua natureza, os relatos de casos clínicos devem ter um número parcimonioso de autores - excepcionalmente mais de 5 . No caso de serem mais de 5 co-autores a carta de submissão deve indicar clara e detalhadamente qual o papel de cada um no manuscrito, de modo a justificar a sua inclusão na linha de autoria à luz dos critérios do ICMJE (http:// www.icmje.org/). A permissão do doente (parente mais próximo, tutor legal) pode ser necessária.

Se o doente(s) descrito nestes manuscritos é identificável, o formulário de consentimento do doente deve ser preenchido e assinado pelo doente(s) (ou tutor/representante legal) e submetido com o manuscrito. Dificultar a identificação do doente através da omissão de dados cientificamente irrelevantes é aceitável, mas a alteração desses dados não o é.

\section{Editoriais}

Os Editoriais são da responsabilidade do grupo editorial, solicitados por convite do Editor-Chefe, e constituirão comentários sobre tópicos actuais ou sobre artigos publicados na revista. Não devem exceder as I 200 palavras, com um máximo de 20 referências bibliográficas e podem conter uma tabela e uma figura. Não têm resumo.

\section{Cartas ao Editor}

As cartas ao Editor consistem em comentários críticos sobre um artigo publicado na revista ou uma nota curta sobre um determinado tópico ou caso clínico. As Cartas ao Editor não devem exceder 600 palavras e 10 referências bibliográficas e podem conter uma figura ou tabela. Não têm resumo.

\section{Imagens em Neurologia}

Esta seção destina-se à publicação de imagens clínicas, radiológicas, histológicas e cirúrgicas.

Uma imagem visual de uma observação neurológica interessante e única, com uma breve descrição do problema clínico e dos achados neurológicos do paciente.

O título não deve ter mais de oito palavras. Os autores devem ser no máximo quatro. As imagens devem ser de alta qualidade e valor educativo. São permitidas até 4 figuras. As legendas devem ser breves e informativas. Setas ou outros símbolos devem ser incluídos conforme necessário para facilitar a compreensão das imagens. $O$ texto não deve exceder 500 palavras, até cinco referências bibliográficas, e deve incluir uma breve história clínica e dados relevantes do exame físico, testes laboratoriais e progressão clínica, conforme apropriado. Não têm resumo. A permissão do doente (parente mais próximo, tutor legal) pode ser necessária.

Nesta secção também serão aceites artigos versando tópicos neurológicos abordados em obras de cariz artístico (incluindo pintura, escultura, teatro e cinema) ou relacionados com os artistas que as criaram.

\section{Perspectiva}

Este tipo de manuscrito é submetido a convite do Conselho Editorial, sendo no entanto também sujeitas a consideração editorial as candidaturas espontâneas para publicação. Pode abranger uma ampla diversidade de tópicos importantes em biomedicina, saúde pública, investigação, descoberta, prevenção, ética, política de saúde ou lei de saúde. Um Autor que deseje propor um manuscrito nesta seção deverá enviar um resumo ao Editor-Chefe, incluindo o título e a lista de autores para avaliação. $O$ texto não deve exceder 1200 palavras, até 10 referências, e até 2 tabelas e 2 figuras. Não têm resumo.

\section{Guidelines}

As recomendações para a prática clínica não devem exceder 4000 palavras, até 6 tabelas ou figuras e até 100 referências. Resumo até 350 palavras. Este tipo de artigo pode ser submetido por grupos de trabalho organizados no âmbito de encontros ou associações científicas, ou grupos de autores com trabalho especializado realizado no tópico em causa.

\section{Referências \\ I. Citação no texto}

Certifique-se de que todas as referências citadas no texto também estão presentes na lista de referências (e vice-versa). As referências devem ser listadas usando algarismos árabes pela ordem em que são citados no texto.

As referências a comunicações pessoais e dados não publicados devem ser feitas diretamente no texto e não devem ser numeradas. As comunicações pessoais devem estar devidamente autorizadas pelo emissor das comunicações, assumindo os autores a responsabilidade pela autorização. A citação de uma referência como "in press" implica que o item tenha sido aceite para publicação. Os nomes das revistas devem ser abreviados de acordo com o estilo da Medline.

As referências a artigos publicados em revistas devem incluir o nome do primeiro autor seguido dos nomes dos restantes autores (num máximo de 6, a partir daí deve ser utilizado et al.), o título do artigo, o nome da revista e o ano de publicação, volume e páginas, e DOI.

Certifique-se que os dados fornecidos nas referências estão corretos. Ao copiar referências, tenha cuidado porque já podem conter erros. A lista de referências deve ser adicionada na secção designada para tal, nunca como uma nota de rodapé. Códigos específicos do programa de gestão de referências não são permitidos. 


\begin{tabular}{|c|c|c|c|c|c|c|}
\hline Article type & Abstract & Keywords & Main text structure & $\begin{array}{l}\text { Max. } \\
\text { words }\end{array}$ & $\begin{array}{l}\text { Tables/ } \\
\text { figures }\end{array}$ & References \\
\hline Original Article & $\begin{array}{l}\text { Max. } 350 \text { words; struc- } \\
\text { tured (Introduction and } \\
\text { Objectives, Methods, } \\
\text { Results and Conclusion) } \\
\text { Portuguese and English }\end{array}$ & $\begin{array}{l}\text { Up to } 6 \\
\text { Portuguese } \\
\text { and English }\end{array}$ & $\begin{array}{l}\text { Introduction; Methods; Re- } \\
\text { sults; Discussion; Conclusion; } \\
\text { Acknowledgments, if any; Refer- } \\
\text { ences; and figure legends, if any }\end{array}$ & 4000 & $\begin{array}{l}\text { Total up } \\
\text { to } 6\end{array}$ & Up to 60 \\
\hline Review Article & $\begin{array}{l}\text { Max. } 350 \text { words; un- } \\
\text { structured Portuguese } \\
\text { and English }\end{array}$ & $\begin{array}{l}\text { Up to } 6 \\
\text { Portuguese } \\
\text { and English }\end{array}$ & $\begin{array}{l}\text { Introduction; thematic sections } \\
\text { at the discretion of the authors; } \\
\text { Conclusion; Acknowledgments, } \\
\text { if any; References; and figure } \\
\text { legends, if any }\end{array}$ & 4000 & $\begin{array}{l}\text { Total up } \\
\text { to } 6\end{array}$ & Up to 100 \\
\hline Systematic Review & $\begin{array}{c}\text { Max. } 350 \text { words; struc- } \\
\text { tured } \\
\text { Portuguese and English }\end{array}$ & $\begin{array}{l}\text { Up to } 6 \\
\text { Portuguese } \\
\text { and English }\end{array}$ & PRISMA & 4000 & $\begin{array}{l}\text { Total up } \\
\text { to } 6\end{array}$ & Up to 100 \\
\hline Case Report & $\begin{array}{l}\text { Max. } 150 \text { words; un- } \\
\text { structured Portuguese } \\
\text { and English }\end{array}$ & $\begin{array}{l}\text { Up to } 6 \\
\text { Portuguese } \\
\text { and English }\end{array}$ & $\begin{array}{c}\text { Introduction; Case report; Dis- } \\
\text { cussion; Conclusion (optional); } \\
\text { References; and figure legends, } \\
\text { if any }\end{array}$ & 2000 & $\begin{array}{l}\text { Total up } \\
\text { to } 4\end{array}$ & Up to 25 \\
\hline Images in Neurology & None & $\begin{array}{c}\text { Up to } 6 \\
\text { Portuguese } \\
\text { and English }\end{array}$ & Unstructured & 500 & $\begin{array}{l}\text { Total up } \\
\text { to } 4\end{array}$ & Up to 5 \\
\hline Editorial & None & None & Unstructured & 1500 & $\begin{array}{l}\text { Total up } \\
\text { to } 2\end{array}$ & Up to 20 \\
\hline Letter to the Editor & None & $\begin{array}{l}\text { Up to } 6 \\
\text { Portuguese } \\
\text { and English }\end{array}$ & Unstructured & 600 & $\begin{array}{l}\text { Total up } \\
\text { to } 1\end{array}$ & Up to 10 \\
\hline Current Perspectives & None & $\begin{array}{c}\text { Up to } 6 \\
\text { Portuguese } \\
\text { and English }\end{array}$ & Unstructured & 1200 & $\begin{array}{l}\text { Total up } \\
\text { to } 2\end{array}$ & Up to 10 \\
\hline Guidelines & $\begin{array}{l}\text { Max. } 350 \text { words; un- } \\
\text { structured Portuguese } \\
\text { and English }\end{array}$ & $\begin{array}{l}\text { Up to } 6 \\
\text { Portuguese } \\
\text { and English }\end{array}$ & $\begin{array}{l}\text { Introduction; thematic sections } \\
\text { at the discretion of the authors; } \\
\text { Conclusion(s); Acknowledg- } \\
\text { ments, if any; References; and } \\
\text { figure legends, if any }\end{array}$ & 4000 & $\begin{array}{l}\text { Total up } \\
\text { to } 6\end{array}$ & Up to 100 \\
\hline
\end{tabular}

\section{Formato}

Uma descrição detalhada dos formatos de diferentes tipos de referência pode ser consultada na "Uniform Requirements for Manuscripts Submitted to Biomedical Journals" (http://www.nlm.nih.gov/bsd/uniform_requirements.html). Liste todos os autores se houver seis ou menos. Et al deve ser adicionado se houver mais de seis autores. Título do artigo, nome da revista, ano, volume e páginas.

\section{Estilo de referência}

Texto: Indicar as referências no texto por número (s) em expoente. Os autores podem ser referidos, mas o número de referência deve ser sempre dado. Lista: Ordene as referências na lista pela ordem em que aparecem no texto Exemplos:

Referência de artigo:

- Com menos de 6 autores

Charvin D, Medori R, Hauser RA, Rascol O. Therapeutic strategies for Parkinson disease: beyond dopaminergic drugs. Nat Rev Drug Discov. 2018; 17:804-22. doi: 10.1038/nrd.2018.136.

- Com mais de 6 autores

Zesiewicz T, Salemi JL, Perlman S, Sullivan KL, Shaw JD, Huang Y, et al. Double-blind, randomized and controlled trial of EPI-743 in Friedreich's ataxia. Neurodegener Dis Manag. 20188:233-242. doi: 10.2217/nmt2018-0013.

Referência de livro:

2. Battler A. Stem Cell and Gene-Based Therapy: Frontiers in Regenerative Medicine. Berlin: Springer; 2006.

Referência de capítulo de livro:

3. Pagel JF, Pegram GV. The role for the primary care physician in sleep medicine. In: Pagel JF, Pandi-Perumal SR, editors. Primary care sleep medicine. 2nd ed. New York: Springer; 2014.
Referências Web:

No mínimo, o URL completo deve ser dado e a data em que o documento foi consultado. Qualquer outra informação, se conhecida (nomes de autor, datas, referência a uma publicação de origem, etc.), também deve ser dada.

Centers for Medicare \& Medicaid Services. CMS proposals to implement certain disclosure provisions of the Affordable Care Act. [Accessed January 30, 2018] Available from: http://www.cms.gov/apps/media/ press/factsheet.asp?Counter $=4221$.

\section{Notas de Rodapé}

As notas de rodapé devem ser evitadas. Quando imprescindíveis, devem ser numerados consecutivamente e aparecer no final do texto.

\section{Agradecimentos (facultativo)}

Tem como objectivo agradecer a todos os que contribuíram para o estudo mas que não têm peso de autoria. Nesta secção é possível agradecer a todas as fontes de apoio, quer financeiro, quer tecnológico ou de consultadoria, assim como contribuições individuais.

\section{Abreviaturas}

Não use abreviaturas ou acrónimos no título e no resumo e limite o seu uso no texto. Abreviaturas não consagradas devem ser definidas na primeira utilização, por extenso, logo seguido pela abreviatura entre parênteses. A menos que a sigla seja uma unidade padrão de medição. Uso excessivo e desnecessário de acrónimos e abreviaturas deve ser evitado.

\section{Unidades de Medida}

Devem ser utilizadas as unidades Sistema Internacional de Unidades. As medidas de comprimento, altura, peso e volume devem ser expressas em unidades do sistema métrico (metro, quilograma ou litro) ou seus múltiplos 
decimais. As temperaturas devem ser dadas em graus Celsius $\left({ }^{\circ} \mathrm{C}\right)$ e a pressão arterial em milímetros de mercúrio $(\mathrm{mmHg})$, e a hemoglobina em $\mathrm{g} / \mathrm{dL}$. Todas as medições hematológicas ou bioquímicas serão referidas no sistema métrico de acordo com o Sistema Internacional de Unidades (SI).

\section{Nomes de Medicamentos e Dispositivos Médicos}

Identifique com precisão todos os medicamentos e produtos pela denominação comum internacional (DCl). Não é recomendável a utilização de nomes comerciais de fármacos (marca registrada), mas quando a utilização for imperativa, o nome do produto deverá vir após o nome $\mathrm{DCl}$, entre parênteses, em minúscula, seguido do símbolo que caracteriza marca registada, em sobrescrito $\left({ }^{\circledR}\right)$. O mesmo princípio é aplicável aos dispositivos médicos.

\section{Nomes de Genes, Símbolos e Números de Acesso}

Aos genes e estruturas relacionadas devem ser atribuídos os nomes e símbolos oficiais fornecidos pelo National Center for Biotechnology Information (NCBI) ou o HUGO Gene Nomenclature Committee. Antes da submissão de um manuscrito relatando grandes conjuntos de dados genómicos (por exemplo, sequências de proteínas ou DNA), os conjuntos de dados devem ser depositados em um banco de dados disponível publicamente, como o GenBank do NCBI, e um número de acesso completo (e número da versão, se apropriado) deve ser fornecido na seção Métodos.

\section{Tabelas e Figuras}

As Tabelas/Figuras devem ser numerados na ordem em que são citadas no texto e assinaladas em numeração árabe e com identificação.

Cada Figura e Tabela incluídas no trabalho têm de ser referidas no texto: "Uma resposta imunitária anormal pode estar na origem dos sintomas da doença (Fig. 2)"; "Esta associa-se a outras duas lesões (Tabela I)".

Figura: Quando referida no texto é abreviada para Fig., enquanto Tabela não é abreviada. Nas legendas ambas as palavras são escritas por extenso.

Cada Tabela e Figura deve ser acompanhada da respectiva legenda, sucinta e clara. As Legendas devem ser auto-explicativas (sem necessidade de recorrer ao texto).

Em relação aos gráficos deve ser explícito se a informação inclui valores individuais, médias ou medianas, se há representação do desvio padrão e intervalos de confiança e o tamanho da amostra (n).

As fotografias deverão incluir identificadores de aspectos cientificamente relevantes (setas e asteriscos). Poderão ser publicadas fotografias a cores, desde que consideradas essenciais.

Cada Tabela deve ser utilizada para mostrar resultados, apresentando listas de dados individuais ou sumariando os mesmos, não devendo no entanto constituir duplicação dos resultados descritos no texto. Devem ser acompanhadas de um título curto mas claro e elucidativo. As unidades de medida usadas devem ser indicadas (em parêntesis abaixo do nome que encabeça cada categoria de valores) e os números expressos devem ser reduzidos às casas decimais com significado clínico.

Para as notas explicativas nas Tabelas devem ser utilizados os seguintes símbolos e sequência: *, †, $\neq, \S, \|, \uparrow, * *,+†$, 㧊.

Se fotografias de doentes forem usadas, estes não devem ser identificáveis ou as fotografias devem ser acompanhadas de autorização por escrito para usá-las.

As ilustrações coloridas são reproduzidas gratuitamente.

Princípios gerais:

- Numere as ilustrações de acordo com a sua sequência no texto.
- Forneça as legendas das ilustrações separadamente.

- Dimensione as ilustrações próximas das dimensões desejadas da versão publicada.

- Envie cada ilustração em ficheiro separado.

A inclusão de figuras e/ou tabelas já publicadas, implica a autorização do detentor de copyright (autor ou editor).

A submissão deve ser feita separadamente do texto, conforme as instruções da plataforma.

Os ficheiros das figuras devem ser fornecidos em alta resolução, 800 dpi mínimo para gráficos e 300 dpi mínimo para fotografias.

A publicação de ilustrações a cores é gratuita, reservando-se a SINAPSE de publicar uma versão a preto e branco na versão impressa da revista.

Material gráfico deve ser entregue em um dos seguintes formatos:

JPEG (.Jpg)

Portable Document Format (. Pdf)

PowerPoint (.ppt)*

TIFF (. Tif)

Excel*

* O material gráfico submetido em formato Powerpoint (.ppt) ou Excel (.xls) deve ser também submetido em formato Portable Document Format (.pdf) dada a possível desformatação quando abertos em computadores e programas sob diferentes definições.

Permissão para publicação: No caso de publicação de tabelas de livros ou revistas os autores são responsáveis por obter permissão, junto dos autores dos trabalhos de onde forem reproduzidos, para a referida publicação, e terão de a apresentar na submissão.

\section{Ficheiros Multimédia}

Os ficheiros multimédia devem ser enviados em ficheiro separado com o manuscrito. O material multimédia deve seguir os padrões de qualidade de produção para publicação sem a necessidade de qualquer modificação ou edição. Os ficheiros aceitáveis são: formatos MPEG, AVI ou QuickTime.

\section{Anexos/ Apêndices}

Quando necessário, os anexos devem ser utilizados para apresentar inquéritos longos ou detalhados, descrições de extensos cálculos matemáticos e / ou listas de itens. Devem ser colocados, se necessário, com legendas. Anexos longos, tais como algoritmos, pesquisas e protocolos, serão publicados apenas online; o URL será fornecido no artigo impresso onde o anexo é citado.

Se houver mais de um apêndice, eles devem ser identificados como A, B, etc. As fórmulas e equações em apêndices devem ser numeradas separadamente: Eq. (A.I), Eq. (A.2), etc .; Em apêndice posterior, a Eq. (B.I) e assim por diante. Da mesma forma para tabelas e figuras: Tabela A. I; FIG. A. I, etc.

\section{Estilo}

SINAPSE segue AMA Manual Style, $10^{a}$ edição (http://www.amamanualofstyle.com) e ICMJE Recommendations for the Conduct, Reporting, Editing, and Publication of Scholarly Work in Medical Journals (http://icmje. org/recommendations)

Última revisão I I Junho 2019 


\section{Políticas Editoriais}

\section{Objetivo e Âmbito}

A SINAPSE é uma revista médica, propriedade da Sociedade Portuguesa de Neurologia (SPN), publicada em edição clássica e em suporte electrónico.

A SINAPSE é orgão oficial das seguintes organizações científicas:

- Sociedade Portuguesa de Neurologia

- Sociedade Portuguesa de Neurocirurgia

- Sociedade Portuguesa do Acidente Vascular Cerebral

- Sociedade Portuguesa de Cefaleias

- Sociedade Portuguesa de Doenças do Movimento

- Sociedade Portuguesa de Estudos de Doenças Neuromusculares

- Sociedade Portuguesa de Neuropatologia

- Sociedade Portuguesa de Neuropediatria

- Liga Portuguesa Contra a Epilepsia

- Grupo de Estudos de Envelhecimento Cerebral e Demências

- Grupo de Estudos de Esclerose Múltipla

- Associação Portuguesa de Electrofisiologia e Neurofisiologia Clínica

- Conselho Português para o Cérebro

A SINAPSE é uma revista internacional com revisão por pares, para médicos que tratam pessoas com doenças neurológicas e para outros profissionais de saúde interessados na estrutura e função do sistema nervoso normal e doente. $O$ público-alvo da revista inclui médicos, enfermeiros, nutricionistas, farmacêuticos, psicólogos, fisioterapeutas, epidemiologistas, investigadores clínicos, outros especialistas envolvidos nos cuidados de saúde (incluindo a área da gestão e administração) e cientistas das áreas básicas e de translação.

A SINAPSE publica artigos em português e/ou inglês. A SINAPSE é publicada continuamente desde 2005.

É uma revista com arbitragem científica (peer review) que publica em acesso aberto, com especial ênfase na área das Neurociências, mas não só.

\section{Liberdade Editorial}

A SINAPSE adopta a definição de liberdade editorial do International Committee of Medical Journal Editors (ICMJE) descrita pela World Association of Medical Editors, que afirma que o Editor-Chefe assume completa autoridade sobre o conteúdo editorial da revista. A Sociedade Portuguesa de Neurologia, enquanto proprietária da SINAPSE, não interfere no processo de avaliação, selecção, programação ou edição de qualquer manuscrito, tendo o Editor-Chefe total independência editorial.

\section{Visão Geral}

A SINAPSE rege-se de acordo com as normas de edição biomédicas elaboradas pelo ICMJE, disponíveis em http://www.icmje.org/, e do Committee on Publication Ethics (COPE), disponíveis em https://publicationethics.org/.

A política editorial da SINAPSE incorpora no processo de revisão e publicação as Recomendações de Política Editorial (Editorial Policy Statements) emitidas pelo Council of Science Editors, disponíveis em https://www.councilscienceeditors. org/resource-library/editorial-policies/white-paper-on-publication-ethics/, que cobre responsabilidades e direitos dos editores das revistas com arbitragem científica.

Estas normas estão em conformidade com as Recommendations for the Conduct, Reporting, Editing and Publication of Scholarly Work in Medical Journals (ICMJE Recommendations), disponíveis em: $h$ ttp://www.icmje.org/recommendations/

\section{Orientação para Apresentação de Estudos}

Os textos devem ser preparados de acordo com as orientações do ICMJE Recommendations for the Conduct, Reporting, Editing and Publication of Scholarly Work in Medical Journals disponíveis em http://www.icmje.org/recommendations/

A SINAPSE recomenda as linhas orientadoras para publicação da EQUATOR network (http://www. equator-network.org). As listas de verificação estão disponíveis para vários desenhos de estudo, incluindo:

- Randomized controlled trials (CONSORT - http://www.consort-statement.org/downloads)

- Systematic reviews and meta-analyses* (PRISMA - http://www.prisma-statement.org/) and protocols (PRISMA-P - http://www.equator-network.org/reporting-guidelines/prisma-protocols/)
- Observational studies (STROBE - http://www.strobe-statement.org/)

- Case reports (CARE - http://www.care-statement.org/)

- Qualitative research (COREQ - http://intghc.oxfordjournals.org/content//9/6/349.long)

- Diagnostic/prognostic studies (STARD - http://www.stard-statement. org/)

- Economic evaluations (CHEERS - http://www.biomedcentral.com/I74I$7015 / 11 / 80)$

- Pre-clinical animal studies (ARRIVE - http://www.nc3rs.org.uk/arrive-guidelines)

* Os autores de revisões sistemáticas também devem fornecer um link para um ficheiro adicional da secção 'métodos', que reproduz todos os detalhes da estratégia de pesquisa.

Os critérios de aceitação para todos os trabalhos são a qualidade e originalidade da investigação e seu significado para os leitores da SINAPSE. Excepto onde indicado de outra forma, os manuscritos são submetidos a peer review cego por dois revisores anónimos, pelo menos. A aceitação ou rejeição final cabe ao Editor-Chefe, que se reserva o direito de recusar qualquer material para publicação.

Os manuscritos devem ser escritos em estilo claro, conciso, directo, de modo que sejam inteligíveis para o leitor. Quando as contribuições são consideradas adequadas para publicação com base em conteúdo científico, o Editor-Chefe reserva-se o direito de modificar os textos para eliminar a ambiguidade e a repetição, e melhorar a comunicação entre o autor e o leitor. Se forem necessárias alterações extensivas, o manuscrito será devolvido ao autor para revisão.

Os manuscritos que não cumpram as instruções para autores podem ser devolvidos para modificação antes de serem revistos.

\section{Critérios de Autoria e Formulário de Autoria}

Como referido nos Requirements do ICMJE, a autoria requer uma contribuição substancial para o manuscrito, sendo necessário especificar, em carta de apresentação, o contributo de cada autor para o trabalho.

\section{Declaração das contribuiçóes individuais assinada por cada autor}

Todos aqueles designados como autores devem cumprir os quatro critérios para autoria, em baixo indicados e todos aqueles que cumprem os quatro critérios devem ser identificados como autores. Os colaboradores que não cumpram os quatro critérios para autoria mas que tenham contribuído para o estudo ou manuscrito, deverão ser reconhecidos na secção de Agradecimentos, especificando o seu contributo.

Cada manuscrito deve ter um "autor correspondente" convenientemente identificado desde a fase inicial de submissão do artigo. Porém, todos os autores devem ter participado significativamente no trabalho para tomar responsabilidade pública sobre o conteúdo e o crédito da autoria.

O autor correspondente deverá obter permissão por escrito de todos aqueles que forem mencionados nos agradecimentos.

\section{Autores são aqueles que:}

I) Têm uma contribuição intelectual substancial, direta, no desenho e elaboração do artigo,

2) Participam na análise e interpretação dos dados;

3) Participam na redação do manuscrito, revisão de versões e revisão crítica do conteúdo; aprovação da versão final;

4) Concordam que são responsáveis pela exatidão e integridade de todo o trabalho.

Além de ser responsável pelas partes do trabalho que tenha feito, um autor deve ser capaz de identificar quais dos co-autores foram responsáveis pelas outras partes específicas do trabalho.

A obtenção de financiamento, a recolha de dados ou a supervisão geral do grupo de trabalho, por si só, não justificam a autoria, mas justificam a inclusão na secção "Agradecimentos".

Qualquer alteração na autoria após a submissão deve ser aprovada por escrito por todos os autores.

Não serão consentidas alterações à autoria ou à ordem dos autores após aceitação do manuscrito para publicação.

Se um medical writer esteve envolvido na redaç̧ão do manuscrito, é ne- 
cessária uma declaração assinada pelo autor correspondente com indicação do nome e se houve o financiamento dessa pessoa. Esta informação deve ser acrescentada na secção "Agradecimentos". A revista SINAPSE exige uma declaração assinada pelo medical writer indicando em que este dá permissão para ser nomeado na secção "Agradecimentos".

\section{Papel do Autor Correspondente}

O autor correspondente funcionará em nome de todos os co-autores como o correspondente preferencial com a equipa editorial durante o processo de submissão e revisão.

O autor correspondente é responsável, em nome de todos os co-autores, pela comunicação com a SINAPSE durante a submissão, fase de peer review e processo de publicação. Também é responsável por assegurar todos os requisitos administrativos da SINAPSE (fornecimento de detalhes de autoria; aprovação da comissão de ética; formulários de conflitos de interesse; consentimento informado).

\section{Consentimento dos Doentes}

Os autores são responsáveis por obter o consentimento informado relativamente a cada indivíduo presente em fotografias, vídeos, descrições detalhadas ou em exames imagiológicos, mesmo após tentativa de ocultar a respectiva identidade. Nomes, iniciais ou outras formas de identificação devem ser removidos das fotografias ou outras imagens. Devem ser omitidos dados pessoais, como profissão ou residência, excepto quando sejam epidemiologicamente relevantes para o trabalho. Os autores devem assegurar que não apresentam dados que permitam a identificação inequívoca dos participantes na investigação/artigo ou, caso isso não seja possível, devem obter o consentimento informado dos intervenientes.

Os estudos envolvendo doentes ou voluntários precisam de aprovação da comissão de ética e consentimento informado dos participantes. Estes devem ser documentados no artigo.

As barras "blackout" ou dispositivos similares não anonimizam doentes em imagens clínicas: é necessário o apropriado consentimento.

\section{Submissão e Publicação Duplicadas}

A SINAPSE não aceita material previamente publicado em forma impressa ou eletrónica, ou manuscritos em consideração simultânea noutra revista.

A SINAPSE endossa as políticas do ICMJE em relação à duplicação de publicações: http://www.icmje.org/recommendations/browse/publishing-and-editorial-issues/overlapping-publications.html.

\section{Política de Plágio}

Seja intencional ou não, o plágio é uma violação grave. Definimos plágio como reprodução de outro trabalho com pelo menos $25 \%$ de similaridade e sem citação. Se for encontrada evidência de plágio antes ou depois da aceitação do artigo ou após a sua publicação, será dada ao autor uma oportunidade de refutação. Se os argumentos não forem considerados satisfatórios, o manuscrito será retratado e o autor sancionado pela publicação de trabalhos por um período a ser determinado pelo Editor-Chefe. O Editor-Chefe poderá ainda decidir informar as instituições de afiliação profissional dos autores acerca do sucedido.

\section{Publicação Fast-Track}

Um sistema fast-track está disponível para manuscritos urgentes e importantes que atendam aos requisitos da SINAPSE para revisão rápida e publicação.

Os autores podem solicitar a publicação rápida através do processo de submissão de manuscritos, indicando claramente a razão por que o seu manuscrito deve ser considerado para revisão acelerada e publicação. 0 Editor-Chefe, com apoio dos Editores Associados ou Conselho Editorial, decidirá se o manuscrito é adequado para publicação rápida e comunicará a sua decisão dentro de 48 horas ao autor correspondente. Se o Editor-Chefe achar o manuscrito inadequado para publicação rápida, o manuscrito pode ser proposto para o processo normal de revisão, ou os autores podem retirar a sua submissão. A decisão editorial sobre manuscritos aceites para revisão rápida será feita dentro de cinco dias úteis.

Se o manuscrito for aceite para publicação, a SINAPSE terá como objectivo publicá-lo electronicamente em 16 dias.

\section{Revisão por Pares}

Todos os artigos de investigação, e a maioria das outras tipologias de artigos, publicadas na SINAPSE passam por uma revisão por pares. Os revisores são obrigados a respeitar a confidencialidade do processo de revisão pelos pares e não revelar detalhes de um manuscrito ou sua revisão, durante ou após o processo de revisão por pares. Se os revisores desejam envolver um colega no processo de revisão, devem primeiro obter permissão do Editor.

Os critérios de aceitação para todos os trabalhos são a qualidade, clareza e originalidade da investigação e seu significado para nossos leitores. Os manuscritos devem ser escritos num estilo claro, conciso, directo. $\mathrm{O}$ manuscrito não pode ter sido publicado, no todo ou em parte, nem submetido para publicação noutro lugar.

Todos os manuscritos enviados são inicialmente avaliados pelo Editor-Chefe e podem ser rejeitados nesta fase, sem serem enviados para revisão por pares. A decisão de aceitação ou rejeição final recai sobre o Editor-Chefe, que se reserva o direito de recusar qualquer material para publicação.

A SINAPSE segue uma rigorosa revisão cega por pares. A SINAPSE enviará os manuscritos para revisores externos seleccionados de uma base de dados pré-existente, ou convidará novos revisores para o efeito.

Todos os manuscritos que não cumpram as instruções aos autores podem ser rejeitados antes de serem revistos. A aceitação final é da responsabilidade do Editor-Chefe.

As cartas ao Editor ou os Editorais serão avaliadas pelo Conselho Editorial, mas também poderão ser solicitadas revisões externas.

$\mathrm{Na}$ avaliação, os manuscritos podem ser:

A) Aceite sem alterações

B) Aceite, mas dependendo de pequenas revisões

C) Reavaliar após grandes alterações

D) Rejeitado

Após a receção do manuscrito, se estiver de acordo com as instruções aos autores e cumprir a política editorial, o Editor-Chefe ou Editor Associado por este incumbido de fazer a gestão do processo de revisão enviam o manuscrito para pelo menos dois revisores.

Dentro de 15 dias, o revisor deve responder ao Editor-Chefe ou Editor Associado, indicando os seus comentários sobre o manuscrito sujeito a revisão e sugestão de aceitação, revisão ou rejeição do trabalho. Dentro de 10 dias, o Editor-Chefe tomará uma decisão que poderá ser: aceitar o manuscrito sem modificações; enviar os comentários dos revisores aos autores de acordo com o estabelecido, para que estes possam rever o artigo; rejeição.

Quando são propostas alterações ao texto inicial os autores têm I 5 dias (período que pode ser estendido a pedido dos autores) para apresentar uma nova versão revista do manuscrito, incorporando os comentários editoriais e dos revisores. Têm de responder a todas as perguntas e enviar também uma versão revista do manuscrito, com as emendas inseridas destacadas com uma cor diferente.

O Editor-Chefe tem 10 dias para tomar a decisão sobre a nova versão: rejeitar ou aceitar a nova versão, ou encaminhá-la para uma nova apreciação por um ou mais revisores.

Qualquer decisão do Editor-Chefe será sempre comunicada ao Autor Correspondente.

Apesar de os editores e revisores desenvolverem esforços para assegurarem a qualidade técnica e científica dos manuscritos, a responsabilidade final do conteúdo (nomeadamente o rigor e a precisão das observações, assim como as opiniões expressas) é da exclusiva responsabilidade dos autores.

\section{Custos de Publicação}

Não haverá custos de publicação (não tem taxas de submissão nem de publicação das imagens a cores, que poderão ser publicadas a preto e branco na versão impressa da revista e a cores na versão eletrónica).

\section{Provas Tipográficas}

As provas tipográficas serão enviadas aos autores, contendo a indicação do prazo de revisão em função das necessidades de publicação da SINAPSE. A revisão deve ser aprovada pelo autor correspondente. Os autores dispõem de 48 horas para a revisão do texto e comunicação de quaisquer erros tipográficos. Nesta fase, os autores não podem fazer qualquer modificação de fundo ao artigo, para além das correcções tipográficas e/ou ortográficas de pequenos erros.

O não respeito pelo prazo proposto desobriga a SINAPSE de aceitar 
a revisão pelos autores, podendo a revisão ser efectuada exclusivamente pelos serviços da SINAPSE.

\section{Erratas}

A SINAPSE publica alterações, emendas ou retrações a um artigo anteriormente publicado, se, após a publicação, forem identificados erros ou omissões que influenciem a interpretação de dados ou informação. Quaisquer alterações posteriores à publicação assumirão a forma de errata.

\section{Retratações}

Os Revisores e Editores assumem que os autores relatam trabalho com base em observações honestas. No entanto, se houver dúvidas substanciais sobre a honestidade ou integridade do trabalho, submetido ou publicado, o editor informará os autores da sua preocupação, procurará esclarecimento junto da instituição patrocinadora do autor e/ou instituição empregadora. Consequentemente, se estes considerarem o artigo publicado como fraudulento, a SINAPSE procederá à retratação. Se este método de investigação não obtiver uma conclusão satisfatória, o Editor-Chefe pode optar po conduzir a sua própria investigação, e pode optar por publicar uma nota de preocupação sobre a conduta ou integridade do trabalho. O Editor-Chefe poderá decidir relatar a situação à instituição dos autores, de acordo com os procedimentos recomendados pelo Committee on Publication Ethics (https:// publicationethics.org/).

\section{Patrocínios}

A SINAPSE é propriedade da Sociedade Portuguesa de Neurologia, que suporta todos os custos de operação da revista. Sem prejuízo deste facto, a SINAPSE poderá angariar patrocinadores, como por exemplo empresas da indústria farmacêutica ou outras, que geram receitas através da publicidade. A publicidade não poderá pôr em causa a independência científica da revista nem influenciar as decisões editoriais e terá de estar de acordo com a legislação geral, bem como das disposições legais específicas da área da saúde e do medicamento.

Nota final: aconselha-se a todos os autores a leitura das Recommendations for the Conduct, Reporting, Editing and Publication of Scholarly Work in Medical Journals, emitidas pelo International Committee of Medical Journal Editors, disponíveis em http://www.icmje.org/

Última revisão: Junho 2019 



\title{
www.spneurologia.com
}

\author{
Órgão oficial de: \\ Sociedade Portuguesa de Neurologia \\ Associação Portuguesa de Electrofisiologia e Neurofisiologia Clínica \\ Conselho Português para o Cérebro \\ Grupo de Estudos de Envelhecimento Cerebral e Demências \\ Grupo de Estudos de Esclerose Múltipla \\ Liga Portuguesa Contra a Epilepsia \\ Sociedade Portuguesa do Acidente Vascular Cerebral \\ Sociedade Portuguesa de Cefaleias \\ Sociedade Portuguesa das Doenças do Movimento \\ Sociedade Portuguesa de Estudos de Doenças Neuromusculares \\ Sociedade Portuguesa de Neurocirurgia \\ Sociedade Portuguesa de Neuropediatria \\ Versão electrónica: www.sinapse.pt
}

Âmbito e Objetivos / Normas de Publicação

Aims and Scope / Editorial Policy

em www.sinapse.pt/normas-de-publicacao

Indexada nas bases bibliográficas:

EMBASE / Excerpta Medica Database (Elsevier)

EMBASE.com (Elsevier)

SCOPUS (Elsevier)

www.indexrmp.com 